

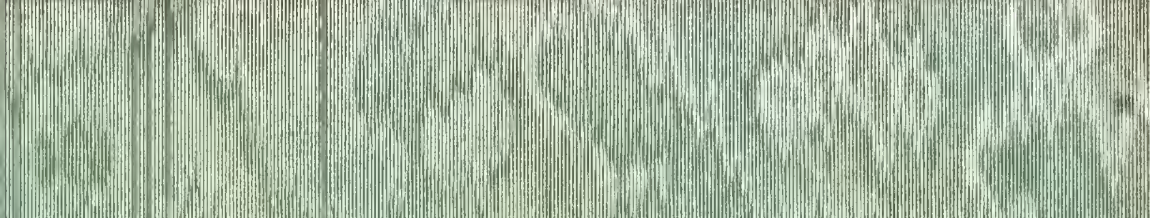

6eter

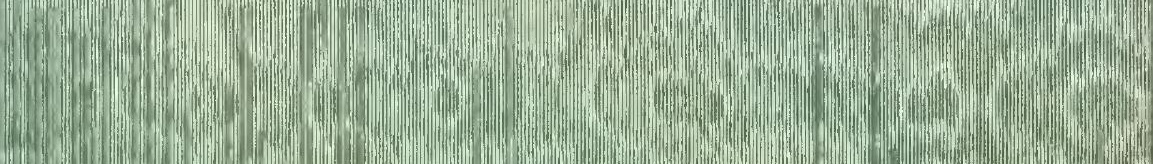

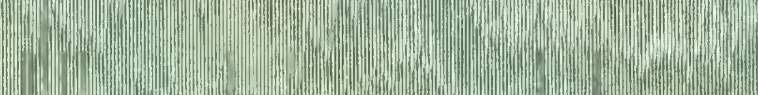

ind

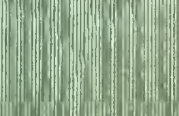

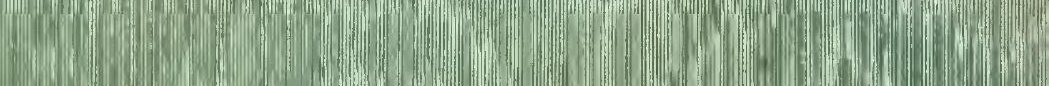

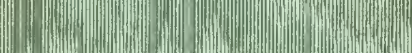

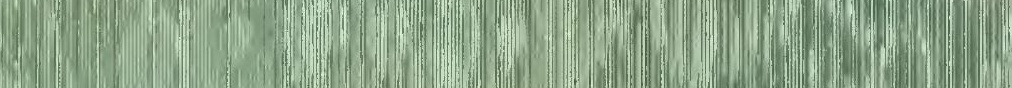

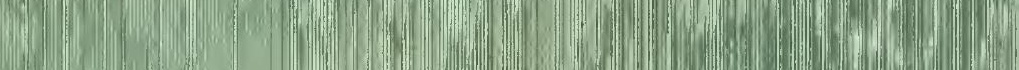

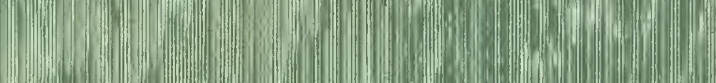
(1)

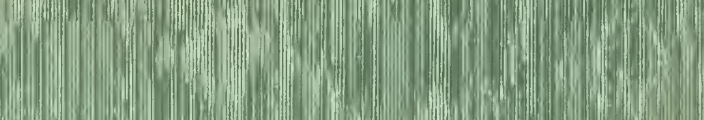

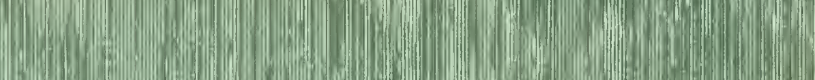

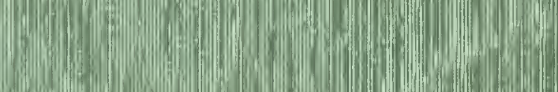

(11. fores ming wastis (6) (6)

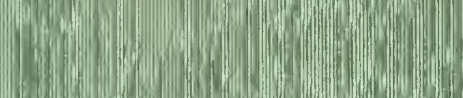
(6)

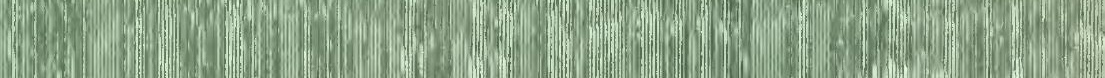

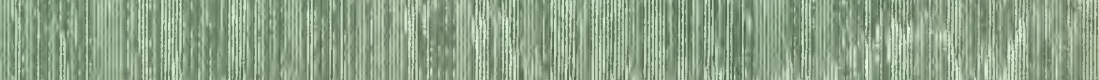
20 


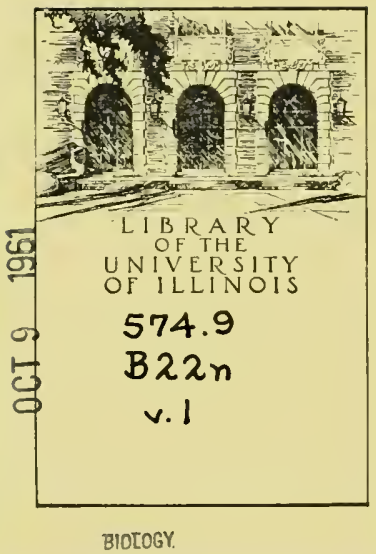


Digitized by the Internet Archive in 2010 with funding from University of Illinois Urbana-Champaign

http://www.archive.org/details/natureneighborse01bant 

EDITOR'S AUTOGRAPH COPIES

HAND BOUND

LIMITED TO TWO HUNDRED AND FIFTY SETS

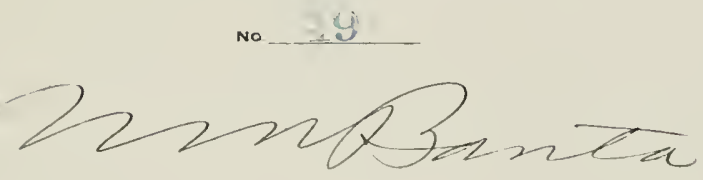






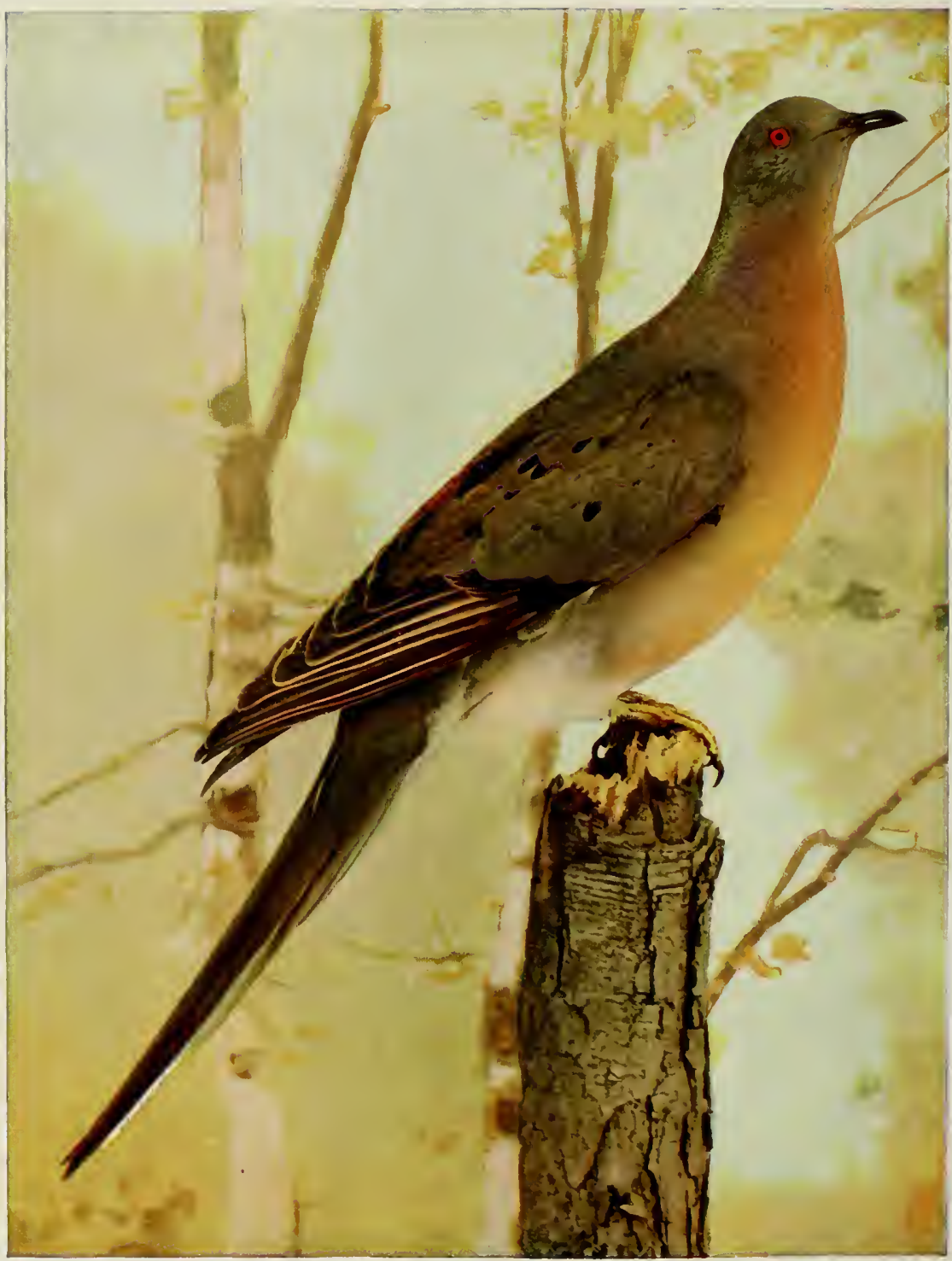


Nature Neighbors 




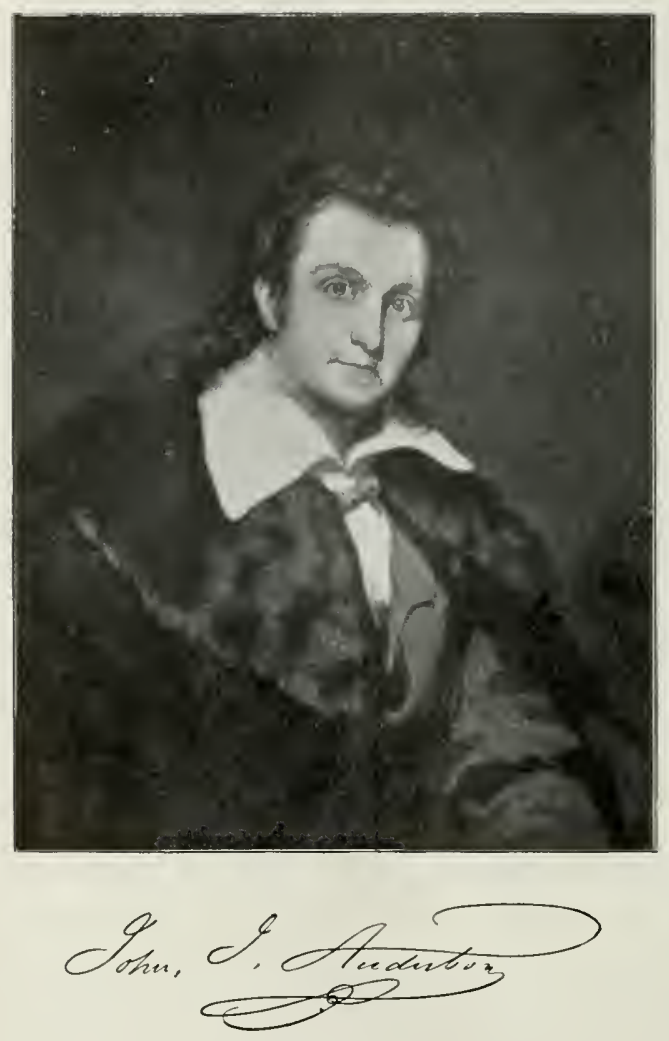

$\sin ^{*}$

FROM THE MUNATLRE FY F. CRUIKSHANK, PURLISHED BY ROBERT HAVELL. January $12, t^{2} 35$. 


\title{
NATURE NEIGHBORS
}

Embracing

\section{BIRDS, PLANTS, ANIMALS, MINERALS}

\author{
In Natural Colors by Color Photography
}

Containing Articles by Gerard Alan Abbott, Dr. Albert Schneider, William Kerr Higley, Thomas Crowder Chamberlin, John Merle Coulter, Davld Starr Jordan, and Other Eminent Naturalists.

Edited by Nathaniel Moore Banta

Six Hundred Forty-eight Full-page Color Plates Containino Accurate Photographic Mlustrations in Natural Colors of Over Fifteen Hundred Nature Specimens

VOL. I-BIRDS

\section{AMERICAN AUDUBON ASSOCIATION CHICAGO}


Copyright, 1914

By Nathaniel Moore Banta 


\section{To}

Nature Lovers 
Nature, the old nurse, took

The child upon her knee, Saying: "Here is a story-book

Thy Father has zritten for thee."

"Come, wander with me," she said,

"Into regions yet untrod,

And read what is yet unread

In the manuscripts of God."

And he wandered away and away

With Nature, the dear old nurse, Who sang to him night and day

The rhymes of the universe.

And whenever the way seemed long,

Or his heart began to fail,

She would sing him a more wonderful song,

Or tell him a more marvelous tale.

- Henry W. Longfellow. 


\section{CONTENTS}

CHAPTER

PAGE

I How to Study the Birds . . . . . . . . 13

II Suggested Exercises in Grouping Birds . . . 25

III Drving Birds . . . . . . . . . . . . 31

IV Long-winged Swimmers . . . . . . . . . . 39

Y Ducks and Geese . . . . . . . . . . . 57

VI WAdrng Birds * . . . . . . . . . . . 89

VII Marsh Birds . . . . . . . . . . . 103

VIII SHORE BIRdS . . . . . . . . . . . 121

IX Quall, Grouse, Etc. . . . . . . . . . 153

$\mathrm{X}$ Birds of Prey . . . . . . . . . . . . 177

XI Woodpeckers, Cuckoos, Etc. . . . . . . 213

XII Goatsuckers, Humming-hirds, Etc. . . . . 235

XIII Flycatchers . . . . . . . . . . . 253

XIV Crows, JaYs, Etc. . . . . . . . . . 265

XV Blackrirds, Ortoles, Etc. . . . . . . . 281

XVI Finches, Sparrows, Etc. . . . . . . . 303

XVII Ixsectivorous Birds . . . . . . . . . 357

XVIII WARtLers . . . . . . . . . . . . 377

XIX Thrashers, Wrens, Etc. . . . . . . . 419

XX Creepers . . . . . . . . . . . . 435

XXI Thrushes . . . . . . . . . . . . 451

XXII Famous Foreign and Introduced Birds . . . 467

XXIII Eggs and Feathers . . . . . . . . . 517 


\section{A FEW OF THE BIRD FAMILY}

The Old Bob White, and chipbird;

The flicker and chce-wink,

And little hopty-slip bird

Along the river brink.

The blackbird and snorwbird,

The chicken-hawk and crane;

The glossy old black crow-bird;

And buzzard down the lane.

The yellowbird and redbird,

The tom-tit and the cat;

The thrush and that redhead bird

The rcst's all pickin' at!

The jay-bird and the blucbird,

The sap-suck and the woren-

The cockadoodle-doo bird,

And our old settin' hen!

—James Whitcomb RILey. 


\section{PUBLISHERS' PREFACE}

There have becn published recently so many excellent works upon the subject of Nature that it might seem presumptuous on the part of the publishers of Nature Neighbors to bring out such a work at the present time. The publishers liave thought this matter over very carefully, and their answer is this:

"Shall the sparrow cease to sing While mocking-birds are caroling?"

There is, however, at least one unique claim the publishers make for this work. There is no other work obtainable which contains the vast number of classified, accurate specimens in natural colors upon the subject of Birds, Plants, Animals, and Minerals of North America which can be purchased at a price within the reach of well-nigh all who earnestly desire it. It lias been the aim of the publishers to present a work upon these subjects that would be highly acceptable to the average reader. Long technical descriptions, however desirable they may be to the specialist, are not to be found in Nature Neighbors. The descriptions of the various nature subjects here given average only about three hundred words each, and are generally gauged to the comprehension of the average grammar school or high school student; and by having an excellent natural color specimen of each subject treated, the information may be obtained quickly and accurately.

Over five hundred bird specimens are here illustrated true to life. These illustrations, together with the excellent descriptions, should prove a most desirable aid to the study and appreciation of birds. Our feathered friends, on account of their great economic value, are given a most important division of this work. In discussing this econonic status of the birds Chester A. Reed says in his "Bird Guide": 


\section{PUBLISHERS' PREFACE}

"The daily consumption of chiefly noxious insects in Massachusetts is twenty-one thousand bushels. This estimate is good for about five months in the year, May to September, inclusive; during the remainder of the year the insects, eggs, and larvae destroyed by our winter, late fall, and early spring migrants will be equivalent to nearly half this quantity. It is the duty, and should be the pleasure, of every citizen to do all in his or her power to protect these valuable creatures, and to encourage them to remain about our homes. The author believes that the best means of protection is the disseminating of knowledge concerning them, and the creating of an interest in their habits and modes of life."

Nearly one thousand color specimens of Plants, Animals, and Minerals are given. These, together with the bird specimens, and the interesting and instructive descriptions, ought to stimulate in the most dormant a love for the great out-of-doors.

The publishers believe with Dr. Albert Schneider that "the true object of nature study is to develop a love for all living things. This should, however, not be carried to extremes, for the universal struggle for existence makes this at best a cruel world. Wantonly killing or injuring any living thing should be condemned. The spirit should be promptly and intelligently discouraged and in its place a feeling of sympathy cultivatcd."

Should the reader of these volumes question the accuracy of the color plates, or the amount or quality of the text, let him wander out with Mother Nature where he will for himself discover

"Tongues in trees, books in the running brooks, Sermons in stones, and good in everything."

Chicago, April 2, 1914. 
Birds 


\section{ACKNOWLEDGMENTS}

The publishers desire to extend their acknowledgment and thanks to the firms who have kindly permitted the use of material in this work: To the publisher, A. W. Mumford, for the articles from "Birds and Nature"; all unsigned articles from this source are marked with an asterisk; to the publisher, John C. Mountjoy, for the articles from the writings of Gerard Alan Abbott and Harold B. Shinn. All articles in Volumes I, II, III, not otherwise accounted for, are written by Gerard Alan Abbott. 


\section{CHAPTER I}

HOW TO STUDY THE BIRDS

ALL temperate North America is inhabited twelve months of the year by bird-life. Our feathered friends exist in greater numbers than most people suppose. It is desirable to commence observations about the first of the year, for in January, though our bird ranks are greatly depleted, the hardy winter residents may be observed with ease, as there is little foliage to obstruct the view. Inexhaustible patience, together with "bulldog persistence," is productive of the best results. We may become botanists or geologists with the realization that the object of our search exists in a given locality; but the bird student finds a constant change taking place in his field. The bird he desires most to examine becomes elusive and keeps him constantly on the alert.

A good pair of field or opera glasses are valuable in determining the colors or markings on various birds, but our chief aim is to learn how and where to look for a given variety.

One need not absent himself from inhabited sections in order to become acquainted with the common and many of the rarer birds. The average $\mathbf{2 0 0}$-acre farm with its natural timber and lake or water-course is an ideal spot for bird study. Birds, in their efforts to avoid their natural enemies, such as prowling mammals, birds of prey, and reptiles, are 
inclined to seek rather than avoid the domains of man. You may be surprised to learn how many birds visit dooryards and orchards in the rural districts annually. Many are only migrants on their way to and from a more northerly latitude, but from ten to twenty-five varieties are common about our dwellings, orchards, and pastures.

Let the bird student who is to acquire a knowledge of bird life by observation avoid the society of other persons when going "birding." It may be interesting to have human companionship and want some one to share with you in the finds you hope to make. Usually the naturalist never lacks companionship simply because he is without the company of other people. To the lover of the prairies, watercourses, and timber lands - for such he must be to successfully acquaint himself with our feathered creatures - there can be no longing for companionslip. The nodding flowers, swaying branches, rippling brooks, and breezy meadows all convey messages of their own.

Let us take for example a given area not to exceed fifty miles from Lake Michigan, anywhere within an imaginary line drawn from a point in southwestern Michigan through northern Indiana and Illinois, thence northward into southeastern Wisconsin. During January we have with us such birds as the downy woodpecker, white-breasted nuthatch, and chickadee, which are fond of each other's company, and quite likely to be observed together, moving about the trees in our dooryards, orchards, or woodlands. The noisy bluejays are more or less in evidence, and the ever-cautious crow visits the pastures and cornfields.

The evening grosbeak, pine grosbeak, Bohemian wax- 
wing, redpoll, white-winged and red crossbills are at this season of the year wintering about the Great Lakes region, feeding in coniferous trees or on orchard buds, and often searching for wild berries and unpicked fruit. A few of our hardy goldfinches may be in the vicinity, and slate-colored juncos in company with tree sparrows are feeding on seeds in the weedy patches. In the open areas the Lapland and Smith's longspurs are busily feeding and calling to each other in their mellow notes. Horned larks, shore larks, and snowflakes are to be seen on the prairies or often about the barnyards when snow is deep.

Old hollow trees afford ample protection for the screech, barred, and horned owls. Occasionally a stray snowy owl from the far north is encountered. The hardy raven often reaches a latitude as far south as Illinois and Indiana, and at this time of the year is apt to be feeding along the shores of the lake looking for aquatic and land animals.

The northern shrike haunts the hedges and parks occupied by our quarrelsome English sparrow or busy tree sparrow. Bands of Canada geese are living on the open water. They collect there during the daytime and just before sunset we see or hear them moving in regular V-shaped flocks to the fields where they feed by night.

The grouse are very companionable at this season of the year; the prairie chickens and bob-whites congregate in immense flocks. The little bob-whites seek shelter among the rail fences or about the underbrush, while the prairie chickens frequent the fields. The ruffed grouse spend the day feeding on the ground, roosting by night in the trees, where no prowling animal may disturb them. 
Herring and ring-billed gulls hover over the rivers and along the shores of the lake, looking for fish or decayed animal matter.

February brings no particular change except that other winter visitors may have arrived or some friends departed. Our true winter ducks are fishing on the open water. They are the old squaw, golden-eyed, white-winged scoter, American and red-breasted mergansers.

During the last ten days of February the great horned owl may be observed sitting upon her two white eggs deposited in an old hawk's nest or in a hollow tree. A few shorteared owls may be seen flying over the frozen marsh in search of rodents.

With our first week of March, several summer residents arrive, and during the month we may expect to see the song sparrow, bluebird, meadow-lark, robin, red-tailed hawk, mallard, woodcock, flicker, red-winged and rusty blackbirds, fox sparrow, bronzed grackle, phœbe, and others. The prairie horned lark is incubating her first setting of eggs.

April brings the purple martin, mourning dove, redheaded woodpecker, brown thrasher, Wilson's snipe, bluewinged teal, vesper, field, grasshopper, swamp, and Henslow's sparrows, towhee, and red-shouldered and sparrow hawks. The myrtle warbler, white-throated sparrows, and ruby and golden-crowned kinglets are in evidence among the underbrush and low trees.

The April rains and sun have taken the frost out of the ground and the warmth of May restores the foliage to our trees and shrubbery. With the unfolding of the leaves appear myriads of insects and worms. Our later birds now 
arrive, including the brightly plumaged orioles, scarlet tanagers, rose-breasted grosbeaks, indigo buntings, and bobolinks. Our daintily attired warblers and retiring flycatchers are haunting the trees, and vireos are carefully inspecting the branches and leaf stems. More ducks, shore birds, and other waterfowl have arrived. The plover and yellow-legs are whistling, and the gallinules and rails call to each other from clumps of old rushes, which afford better protection than the young vegetation.

The phœbe, bob-white, woodcock, song sparrow, redshouldered hawk, screech owl, mourning dove, bluebird, robin, bluejay, crow, brown thrasher, and towhee are all busily engaged in the duties of hatching their eggs and rearing their young. This is the season when birds in their ecstasy become less cautious, and afford splendid opportunities for observation.

You should arise before dawn, because with the first glimmer of daylight certain birds burst forth into song. Before the sun has risen, many voices may be heard on the meadows, in the woodlands, or about the marshes. Some birds found singing at this time of the year are silent during the day, but with the approach of twilight we are greeted with the carol of the wood thrush, the hymn of the vesper sparrow, and the cooing of the mourning dove. Night hawks are conspicuous, and, as the curtain of night falls, we hear the mournful cry of the owl and the weird note of the whip-poor-will.

In June nesting is at its height. The male birds are also in full song, but the opportunity for bird observation is not so good. Our feathered friends have more serious obliga- 
tions and are now too preoccupied to derote much time to courtship, so we see less of the female. The males may be seen or heard regularly for the next two to four weeks.

Birds such as the prairie horned lark, killdeer, song sparrow, phœbe, bluebird, and robin are preparing to rear a second brood. Two weeks ago their first nests were occupied with eggs that hatched before many of our summer residents had returned from the South. If we venture into the meadows, through the orchards, or to the woodlands, many fledgelings are encountered. The parents are uneasy at our presence, and manifest their displeasure by showing little fear in their efforts to protect their offspring. The flycatchers, vireos, and thrushes are now sitting upon their eggs. These birds usually rear but one brood during a season.

The marshes are gradually drying up, and the few hollows which still contain water are attractive places for rails, herons, and bitterns.

In July the goldfinches act as vivacious as most birds do in May. 'Thistle down, now floating in the air, is used as a lining for their nests, while they largely subsist on the thistle seeds. By the middle of July our graceful swallows have completed household duties and are congregating along the marshes and lakesides. Flocks of tree and bank swallows often mingle and move over the marshy sloughs, alighting at sundown on the telephone and telegraph wires. Few birds sing during the heat of the day except indigo buntings, towhees, dickcissels, field sparrows, song sparrows, and robins. These birds are more domestic and prolific than swallows, and the duties of rearing a second family will consume the entire month. 
The bobolink is losing his gay coat of black and white and buff, and is preparing for a raid upon the southern rice fields, where he will travel under the disguise of "ricebird." Less capable of flight while shedding his feathers, he retires to cornfields to molt, where he is afforded an unobstructed view on all sides as a protection against natural enemies. August is the general month for molting. About the only birds demonstrative about nest-building at this late date are some of the goldfinches and cedar waxwings. Many of the latter have remained in flocks through the entire winter, spring, and early summer, but are now busy nest-building in some isolated orchard, shade tree, or evergreen. A walk through the timber, along the water-courses, and over fields will disclose little bird-life, as birds are naturally shy and evasive while molting. Their flight, even, is defective, so they remain within the shelter of heavy grass or brush. We may see a dozen wood ducks about some little lagoon or wooded lake, probably two adults and their offspring. Woodpeckers may be seen moving about in fanilies, two redheaded woodpeckers guiding four or five immature birds which have not attained the scarlet headgear. Only during the early hours of morning do the birds show any animation. At that time we occasionally hear the song of a catbird, the call of a cuckoo, the note of a pewee, and the mellow twitter of a goldfinch as he darts back and forth, singing at every dip of his undulating flight.

This is a good month to examine and collect birds' nests. They have not long been exposed to the weather, because the foliage is still on the trees. Many nests are kept in their proper shape only by removing the twig, stem, or limb to 
which they are attached. The weather is still more or less sultry, but we may venture into the damp or dark places without the annoyance of mosquitoes, gnats, and other insects which are so numerous during June and July.

With the arrival of September we see many new forms about our shade trees, gardens, and groves. They are not usually our summer residents in different plumage, but birds from a more northerly latitude. The warblers have begun their annual southward journey. Along the pebbly beaches and sandy shores hundreds of little waders are moving about in a systematic search for aquatic life. Many of them are marked differently than they were five months ago. During the interval they have visited the tundras and barrens about the Arctic Ocean, deposited their four eggs, reared their young, and are now feasting as they move by degrees to the South. Three months from now some of them will be hundreds of miles south of the equator.

Owls seek more open situations at this time of the year. They realize that the territory is populated by transients, and the time is to be improved by hunting in the open, where smaller forms of bird-life are so much in evidence. It is still possible to find an occupied nest of the goldfinch or cedar waxwing, though undoubtedly the birds have been accidentally delayed. The male goldfinch is losing his brilliant coat of black and yellow and is assuming a covering of dull greenish-black not unlike his mate. Great flocks of blackbirds, comprising red-wings, rusty blackbirds, and cowbirds, forage in the marshes and descend upon the grain fields. The graceful little terns called seagulls are moving leisurely southward along water-courses. 
On the upland prairies large flocks of golden plover are feeding on wild berries, grasshoppers, and crickets. The birds have lost the handsome black breasts and there is nothing about their appearance to identify them, save their clear mellow whistle, or call-note, which they use when moving swiftly in compact flocks over our uncultivated land. As Helen Hunt Jackson says:

"October the month of carnival of all the year, When Nature lets the wild carth go its way, And spend whole seasons on a single day."

With the fall or turning of the leaves in October we lose our insectivorous birds. Belated warblers are hurrying southward and occasionally a phœe may be seen lingering about the nesting place, loath to leave the little bridge or old well with its past associations. As we walk through the dead leaves of the woodlands, willow, olive-backed, and hermit thrushes are startled from the ground and fly to the nearest branch of some leafless tree. Small flocks of whitethroated, fox, or white-crowned sparrows are busily feeding in the fence corners. The junco has returned from the Canadian provinces and will remain with us until a mantle of snow forces him to seek food elsewhere.

Golden and ruby-crowned kinglets moving in company with brown creepers comprise a fearless trio while inspecting the trees on our lawns and in our parks. The little kinglets look twice as large as they did last April, the fluffed feathers offering more resistance to the October chill. The frosted vegetation in sloughs and bayous now exposes 
many a gallinule, coot, and rail, where many are shot by pot-hunters lacking in sportsmanship.

The large cities are revisited by various forms of sea birds, providing there is a water frontage. During the late fall, winter, and spring months Bonaparte's, herring, and ring-billed gulls visit the shores of lakes and rivers, especially when these waters are navigable, to procure the refuse. Wilson's snipe is again on the marsh, where his flight taxes the skill of the best gunners.

November leaves us with a limited variety of birds, most of which are found in flocks. Robins still loiter in sheltered places and the hardy meadow-lark lingers about his favorite pasture. On a bleak morning we hear his merry chipper, which seems a protest against snow and ice. Flocks of mallards gorge themselves in the cornfields. The birds are then prepared for a continuous flight of two thousand miles, though they defer such journey as long as they can find open water nearer. We have the mallard with us from October to late in December. With January comes a general freeze-up of his feeding grounds, so he moves just far enough south to return at the first thaw in February. Many mallards reach Canada in March. Fifty years ago we had this noble game bird with us at least eleven months in the year. Great flocks of prairie chickens are now roaming the cornfields. Families have combined with others and these flocks join larger ones until hundreds of birds have banded together so to remain until April.

Field and tree sparrows are sheltered along the roadsides in the thickets and about truck gardens. A few large hawks, such as the red-tailed, goshawk, and rough-leg, are 
in evidence. The two latter are migratory, but of ten spend the winter with us. The rough-leg is sluggish, his habits reminding one of an owl. The little screech owl calls weirdly through the long nights of November, when other bird voices are hushed. December causes the crows to "hustle for a living." Rather than migrate during severe weather they sometimes starve. One good word may be said here in behalf of the crow; he has never been known to eat the remains of his own kind, nor does he attempt to fight with his fellow birds over some morsel which he may have chanced to acquire.

This is a good time to set up a little "free lunch counter" for the birds by nailing a board to your window-sill or nearby tree. You will undoubtedly make friends with several sociable birds. Place a generous amount of corn, bread crumbs, and suet on this shelf, or the latter, if preferred, may be tied to a limb. Downy woodpeckers and whitebreasted nuthatches are very fond of suet, and the nuthatch will usually prevail upon some chickadee to visit the same eating-place. Occasionally a bluejay or English sparrow will steal the larder intended for the other birds, thus justifying one in shooting them on sight.

Visit the woods on a cold December morning when snow is on the ground. You will be surprised at the friendliness of the chickadee. He even alights upon your head or shoulder, and will readily eat bread crumbs from your hand. G. A. A. 



\section{CHAPTER II \\ SUGGESTED EXERCISES IN GROUPING BIRDS}

Birds of THE Dooryard

BlueJay, mocking-bird, house wren, robin, English sparrow, chipping sparrow, and chimney swift.

\section{Birds That Feed on the Ground}

The various grouse, also the plover. In addition to which we might add the roadrunner, mourning dove, bobolink, meadow-lark, horned lark, fox sparrow, English sparrow, dickcissel, crow, towhee, and brown thrasher.

\section{Birds That Feed Among the Foliage of Trees and Bushes}

The cuckoos, scarlet tanager, blue-gray gnatcatcher, and the kinglets.

\section{Birds That Feed on Trunks of Trees}

All the various woodpeckers and sapsuckers; in addition, we may add the black and white warbler, brown creeper, titmice, nuthatches, and chickadees.

\section{Birds That Feed on the IVing}

This comprises the swallows, including the purple martin; also the nighthawk and its relatives, the red-headed woodpecker, the ruby-throated humming-bird, cedar waxwing, the rarious flycatchers and vireos, and the terns. 
Birds That Feed Around the Edge of Pools and Lakes

The various snipe, sandpipers, plovers, except the upland plovers; also woodcock, Louisiana water-thrush, and dipper.

\section{Birds That Feed by Wading}

The various herons, rails, and bitterns, with their near relatives; also the flamingo, the white ibis, the roseate spoonbill, the yellow-legs, and the long-billed curlew.

Birds That Feed While Swimming in Shallow Water

The various river ducks; also Canada goose, Wilson's phalarope, and avocet.

\section{Birds That Feed by Diving for Fish}

Include the loons, the grebes, the murres, the tufted puffin, cormorant, osprey, belted kingfisher, and the merganser's.

\section{Birds That Feed on Mammals}

The shrikes, owls, and hawks.

\section{Birds That Feed on Carrion}

The gulls, kittiwake, vultures, crows, raven, and magpie.

\section{Birds That Lay White Eggs}

As a rule all birds that nest in hollow trees or in deep burrows, where the eggs remain in the dark, lay white eggs. Following is a partial list: double-crested cormorant, white pelican, hooded merganser, bluejay, Canada goose, Wilson's 
petrel, tufted puffin, various owls, bald eagle, passenger pigeon, mourning dove, various woodpeckers, belted kingfishers, bob-white, quail, phœbe, least flycatcher, goslıwk, Carolina parakeet, purple martin, tree swallow, short-billed marsh wren, and ruby-throated humming-bird.

\section{Birds That Do Not Construct or Use ANy Nest}

Brunnich's murre, turkey vulture, black vulture, whippoor-will, and nighthawk.

Birds That Lay Their Eggs in Hollows on Nests Constructed By Other Species

Horned owl, screech owl, burrowing owl, barred owl, saw-whet owl, sparrow hawk, wood duck, hooded-merganser, bufflehead, American merganser, golden eye, cowbird, house wren, and tree swallow.

Birds Which Are Resident Throvghout the Year in a Given LOCALITY

The various grouse, crow, bluejay, Canada jay, Clark's nutcracker, the nuthatches, downy woodpecker, screech owl, horned owl, barred owl, the eagles, chickadees; some of the resident birds migrate for a short distance, so that in some cases, while we may have some species of bird throughout the year, it may be a different bird in winter and summer.

Birds With Conspicuous Red or Orange Plumage

This list is so easily compiled by consulting the pictures that no printed list is necessary. 


\section{Birds That Are White}

White-tailed ptarmigan, snowy owl, common tern, caspian tern, kittiwake, ring-billed gull, and snowflake. Are all these birds white in both winter and summer? Do they differ from albinos?

Species Which Are Fanous as Gane Birds

The various ducks, including the Canada goose, plovers, snipes, and sandpipers, including woodcock, and grouse.

Sweetest SoNg Birds

Thrushes, including the veery and robin; also the dipper and brown thrasher, mocking-bird, ruby-crowned kinglet, rose-breasted grosbeak, the wrens, indigo bunting, meadowlark, bobolink, the sparrows, purple martin, Maryland yellow-throat, and yellow-breasted chat.

\section{Birds With Crests and Topheots}

This is so easily compiled that no list is necessary.

Birds Frequenting Barss and Oetbulidings

Purple martin, barn swallow, phœbe, and cliff swallow.

Birds That Live ix Otr Orchards

Flicker, bluebird, orchard oriole, mourning dore, cedar waxwing, yellow-billed and black-billed cuckoos, and redeỵed rireo.

Birds That Frequent the Trees and Uxderbrush Alose the Roadstoes axd DrTenats

Baltimore oriole, kingbird, brown thrasher, loggerhead shrike, and least flycatcher. 
Birds Frequenting Neglected Fields axd Weed Patches

Slate-colored junco, tree sparrow, vesper sparrow, dickcissel, and goldfinch.

Birds That Live in Our Meadows and Pastures

Lark sparrow, grasshopper sparrow, bob-white, meadowlark, cowbird, and bobolink.

\section{Birds Inhabiting Upland Pratries}

Horned larks, prairie hen, upland plover, Saranna sparrow, Smith's longspur, and burrowing owl.

\section{Birds That Live ox the Timbered Hillsides}

Red-headed woodpecker, crow, red-tailed hawk, screech owl, whip-poor-will, warbling vireo, red-bellied woodpecker, and scarlet tanager.

Birds Partul to Berry Bushes, Saplings and Syall Willows

Indigo bunting, yellow warbler, song sparrow, field sparrow, fox sparrow, traill's flycatcher, golden-crowned kinglet, and towhee.

\section{Birds That Are Partal to Evergreens}

Bronzed grackle, pine warbler, cross-bills, blackburnian warbler, bay-breasted warbler, blue-headed vireo, and pine grosbeak.

\section{Birds That Haunt Damp Grassy Places}

Maryland and western yellow-throat, marsh wrens, swamp sparrow, and short-eared owl. 
Birds Inhabiting Damp Underbrush

Woodcock, yellow-breasted chat, cardinal, rose-breasted grosbeak and redstart.

\section{Birds of Damp Woodlands}

Yellow-bellied flycatcher, olive-sided flycatcher, ruffed grouse, wood pewee, veery, wood thrush, black and white warbler, and ovenbird.

\section{Birds Frequenting Our Timbered Lakes}

Wood duck, hooded merganser, loon, tree swallow, crested flycatcher, Canada jay, and osprey.

Birds Frequenting Trees Along Streams and Lakes

Horned owl, sparrow hawk, prothonotary warbler, downy woodpecker, belted kingfisher, Louisiana water thrush and chickadee.

Birds Living About Open Ponds and Grassy Slovghs

Marsh hawk, mallard, blue-winged teal, pied-billed grebe and black tern.

Birds That Inhabit Open Swamps and Bogs

King rail, sora rail, Virginia rail, coot, Florida gallinule, bittern, least bittern, red-winged blackbird, yellow-headed blackbird, long-billed marsh wren, and black-crowned night heron.

Birds Frequenting Our Sandy Shores and Gratel Beaches

Spotted sandpiper, killdeer, piping plover, black-bellied plover, common tern, willet, and sanderling. G. A. A. 


\section{CHAP'TER III}

\section{DIVING BIRDS}

Six species of Grebes, or Lobe-footed Divers, are found within the limits of North America. Grebes are so aquatic that they seldom venture upon the land, where they are almost helpless, resting on the entire tarsus instead of toes. They dive and swim with such skill that they were able to escape the shot by "diving at the flash" of the muzzle-loading shotgun formerly in use. Various popular names are applied to show the skill of these birds in diving; they can swim with only the tip of the bill above water. They subsist largely on fish, which they are able to capture under the water, propelling the body by feet alone. The nests of the grebes are masses of decayed vegetation, which the birds gather beneath the water and arrange among the growing regetation by anchoring to aquatic plants so that the nests rise and fall with the water.

The Loon family comprises five species in the Northern Hemisphere, three being found in the Great Lakes region. They are almost as aquatic as are the grebes. They visit the land only to nest, at which time they move by using the bills, wing, and feet, nesting so near shore as to slide noiselessly into the water. They capture fish, as do the grebes, by pursuing under water, progressing by means of feet alone.

The Murres, Puffins, Dovekies belong to the family 
Alcidae, which numbers thirty species, all found in the Northern Hemisphere, most of them on the Pacific Coast. They pass most of their lives on the open sea. They nest in colonies, vast numbers frequenting cliffs. On land they are slow and awkward, but are good fliers, swimmers, and divers. In pursuing fish beneath the water they use wings as well as feet. Many of these lay but one egg.

\section{HORNED GREBE}

The Horned Grebe, often called Hell Diver, Die-dapper, or Water Witch, is frequently mistaken for the piedbilled grebe. A bird of central North America, occurring from the Atlantic to the Pacific, it is a common migrant in the Great Lakes region. It nests in northern Minnesota and in the lagoons of Manitoba and Alberta, and is found in the Devil's Lake region of North Dakota.

In 1900, while camping at Sweetwater Lake, North Dakota, I found holboells, pied-billed, and horned grebes inhabiting the grassy sloughs along low prairies. In the regions about the shores of the lakes one thousand western grebes were breeding in company with five hundred eared grebes. In general appearance and size horned and earcd grebes are quite similar, the eared being the western form. While wading about among these floating nests of the grebes, the birds would dive, striking against my boots as they moved about beneath the water.

The notes of the grebes are shrill and penetrating, reminding one of the constant trilling of frogs and toads in the marshes in early spring. When hundreds of grebes 

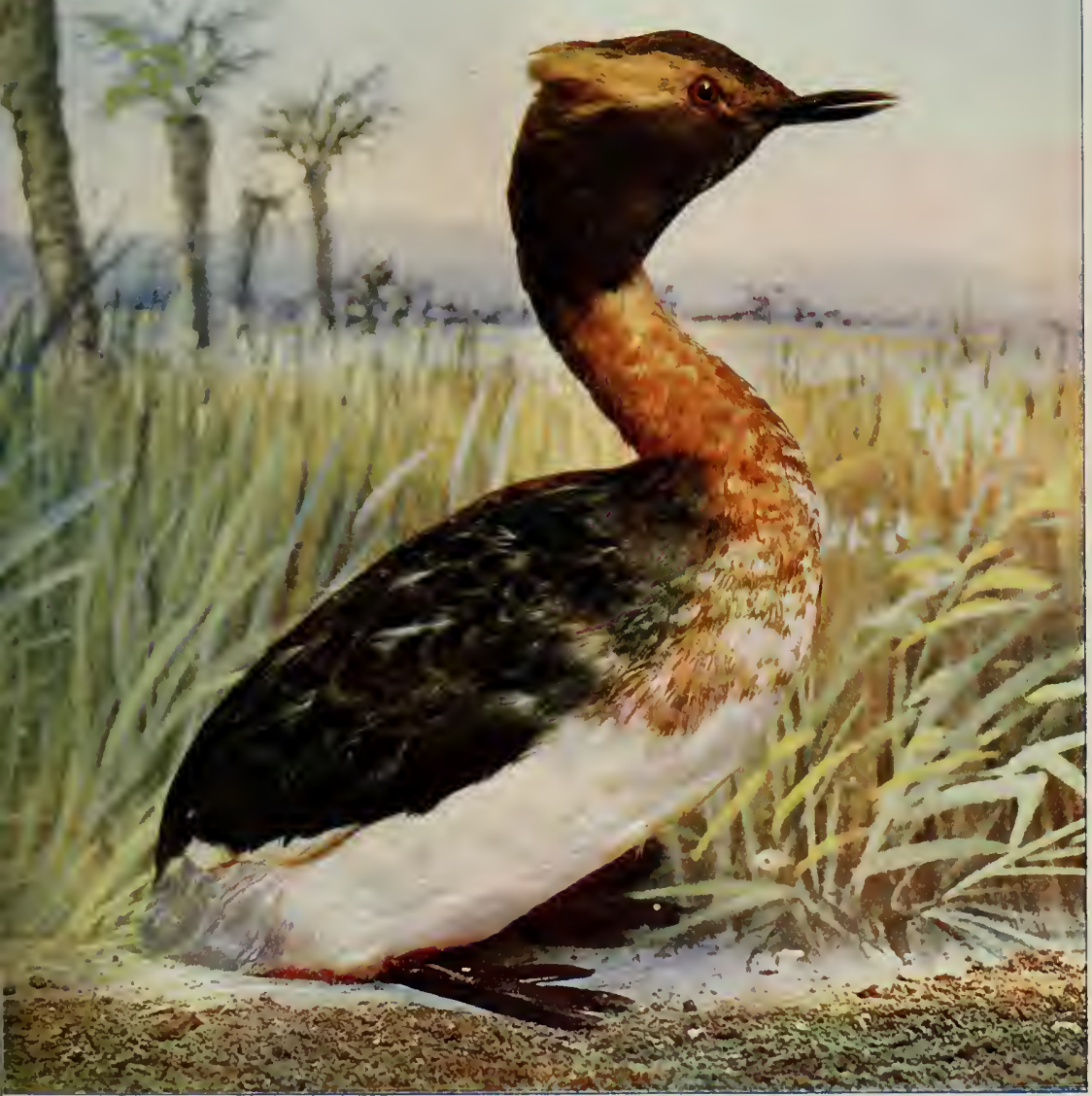



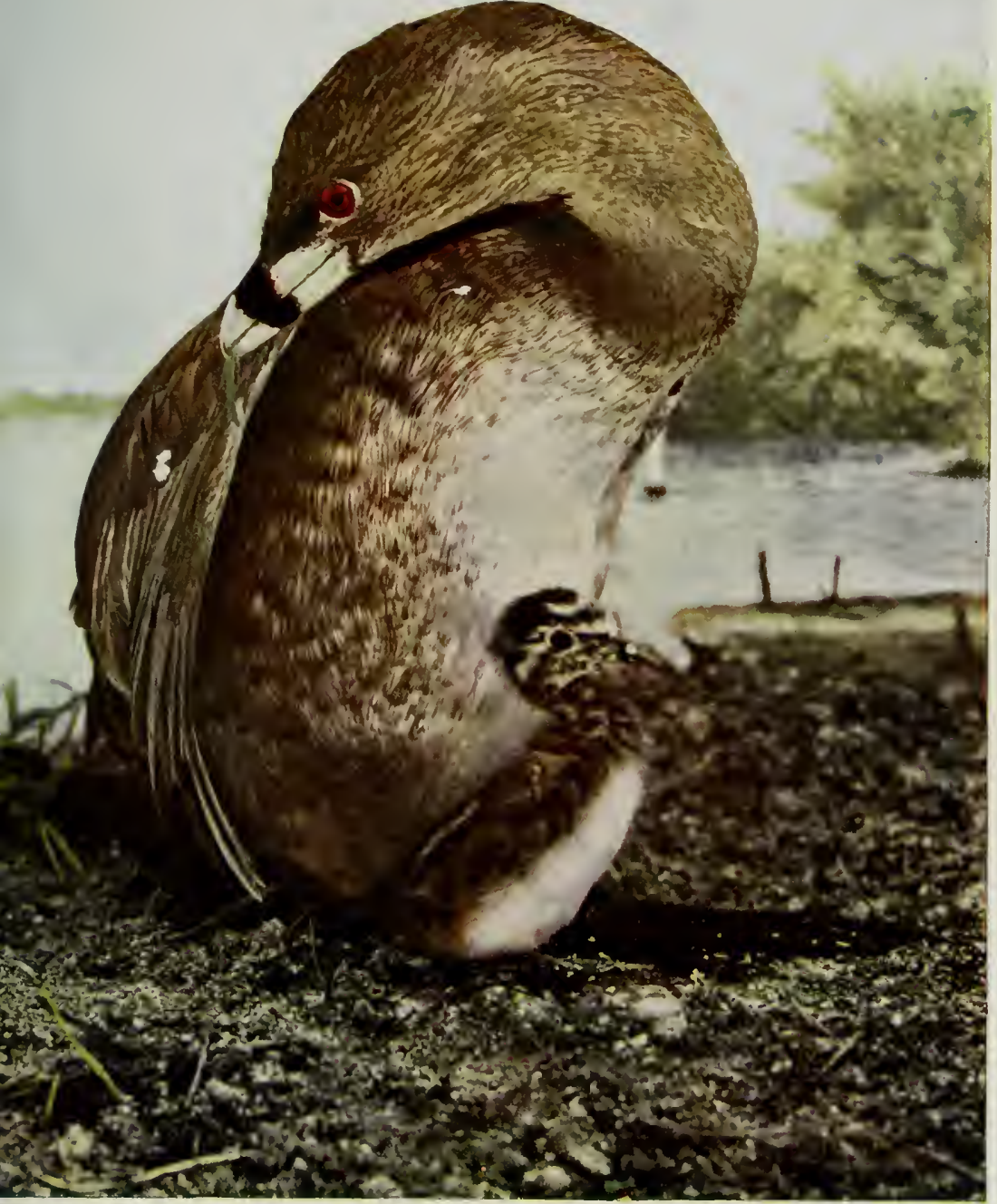



are calling constantly during the night, the sound is weird, but so in keeping with the desolate country as to be scarcely noticeable after a few days. It is an even tone pitched in a high key like the strident tones of a locust.

The birds lay from four to nine bluish-white eggs, which they cover with decaying vegetation, which soon stains them. When the eggs are thus covered the heat from the sun's rays and the decay of the regetation produce a warmth sufficient to incubate the eggs without the presence of the bird; the grebes, however, often sit upon their nests, or at least remain close, to guard their treasures. When the young are hatched they may be seen riding on the backs of the old birds in the open water, but usually close to cover. At the approach of danger the old bird dives like a fish and arises to the surface many yards away, with the little fellows still clinging on.

\section{PIED-BILLED GREBE}

The Pied-billed Grebe, commonly called Hell-diver, Die-dapper, Dabchick, Water Witch, is often mistaken for the horned grebe. It ranges from Argentine Republic north to Hudson Bay and Great Slave Lake, breeding throughout the range.

Grebes are unexcelled as divers, as they swim and dive like a fish, and reach a depth of five or six fathoms. They are the most aquatic of all North American birds found in the interior, but are helpless on land, unable to walk or rise on the wing. Like other grebes, they rest on the tarsus while on land, as shown in plate. The toes are not connected by a web, as in the ducks, but each toe is equipped 
with separate lobes, enabling the birds to propel themselves through the water, either on or beneath the surface, with great rapidity. They have no tail feathers.

The floating nest of decaying vegetation is ancliored to the reeds or rushes in from one to five feet of water. The birds obtain the material for these floating nests from the bottom of the lakes and marshes where the nest is situated. It is estimated that the birds make two hundred trips below the surface to obtain the required amount of nesting material. The pied-billed arrives in the Great Lakes region in April, and may remain to breed around the lagoons and lakesides of Illinois and Indiana. A few pairs nest within the city limits of Clicago.

The writer's collection contains a nest of nine eggs taken June 18, 1902, in Cook County, Illinois. The eggs of all the grebes are immaculate when laid, but soon become badly nest-stained.

\section{LOON}

The Loon, or Great Northern Diver, is migratory through northern Illinois, altlough a few formerly bred in the Fox Lake region. Michigan and Wisconsin are favorite summer resorts for the loon, and many pass northward into Canada to breed. During the spring and fall loons abound on the Great Lakes, and are frequently caught in fish nets or on set lines which have been baited with minnows. One pair of loons usually reign supreme on each little inland lake among the northern woods.

They usually migrate by night, flying high. During the breeding season their weird notes echo among the pines 


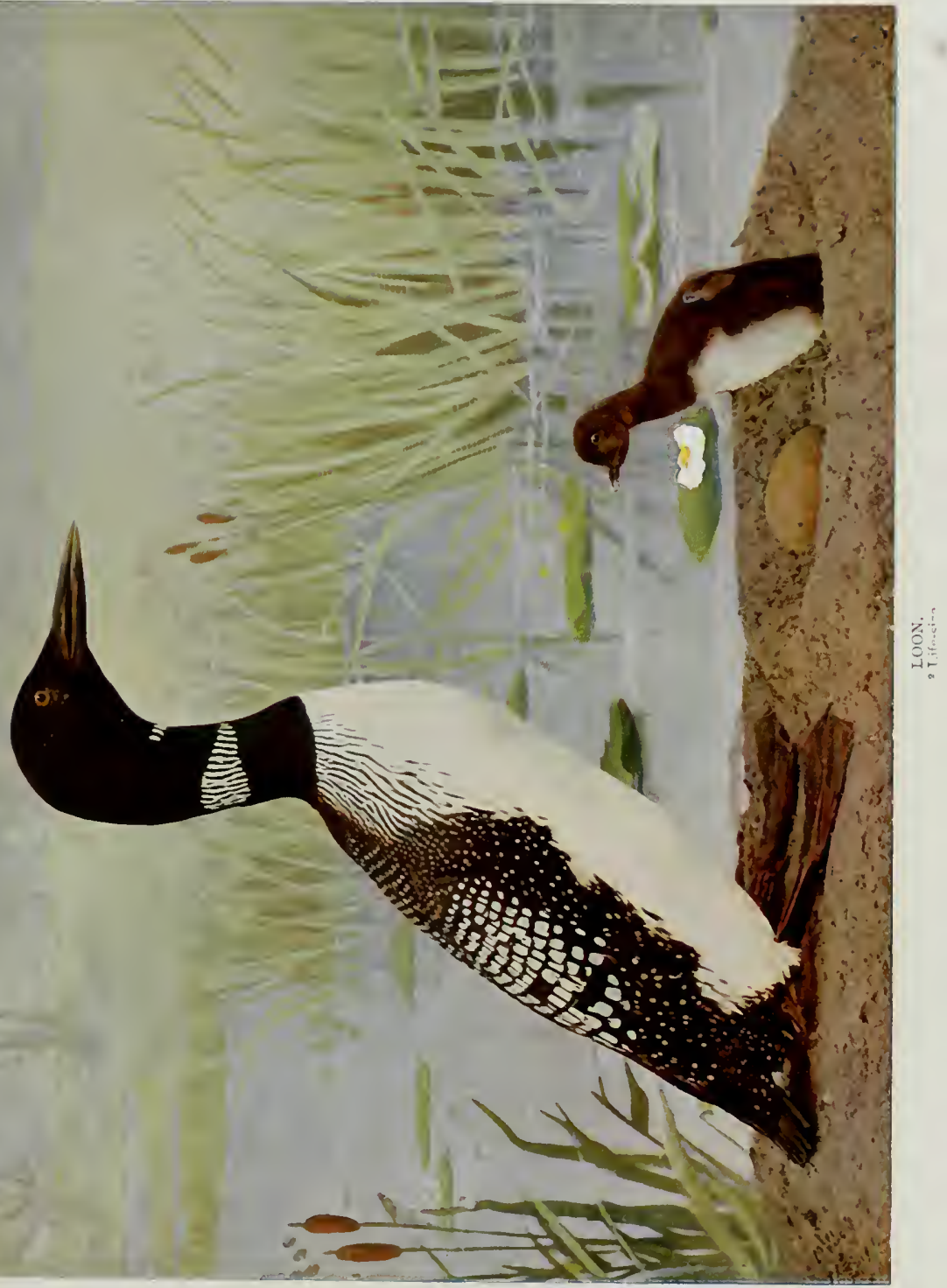




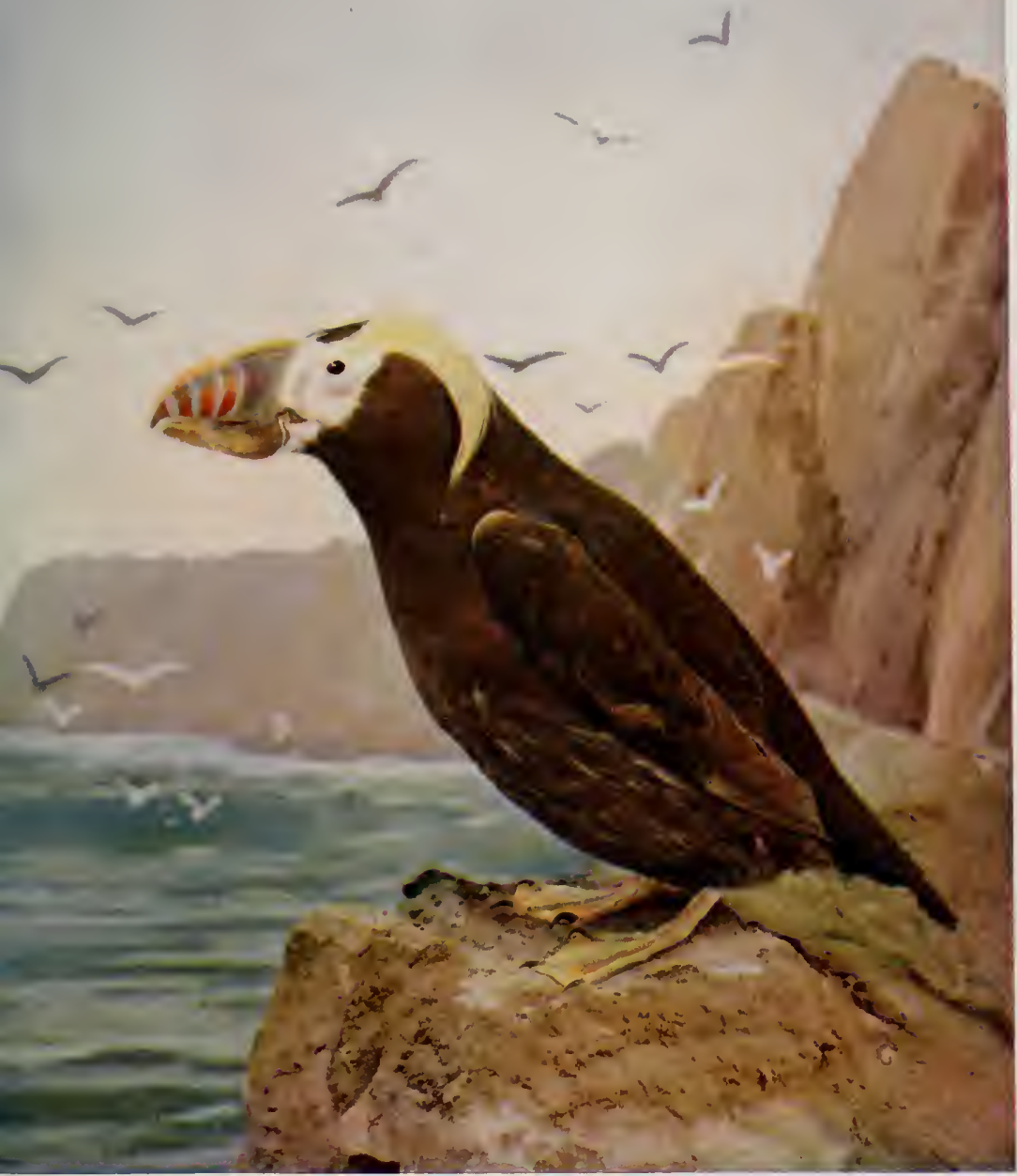



when all else is still. The cry of the loon is not unlike an outburst of maniacal laughter, hence we frequently hear the expression, "crazy as a loon." Like the grebes, the loons are practically helpless when on land, but are excellent swimmers and divers and strong direct fliers.

The nest is constructed near the water, often on a partially submerged muskrat house. Sometimes the two large eggs are laid on the bare sand or gravel just above the water's edge, so that it is possible for the parent to slip quietly from her nest into the water and swim rapidly to the farther side without exposing even the head. The eggs are dark olive green, spotted and blotched with brown.

\section{TUFTED PUFFIN}

The Tufted Puffin is a western species living on the Pacific Coast from California to Alaska. It also frequents the opposite shores of the same ocean, occurring in considerable numbers from Japan to Bering Strait. Four varieties of puffin are found in America.

The bills of the puffin are short, stout, and extremely broad vertically, with little horizontal width. The upper mandible projects beyond the lower, producing a resemblance to the parrot. A peculiar comb-like excrescence forms on bill at nesting time, a sex mark. The general color of the bird is black with a conspicuous white-faced mask; the long flowing yellow ear tufts are curved inward like the horns of a ram.

Aside from the gulls and terns, puffins are probably the uneasiest birds about their breeding grounds. When not 
excitedly moving about the rocks, they are generally uttering their piercing notes, often more shrill than the scream of the gull. When the birds enter their burrows they may be heard uttering a sound not unlike a disturbed feline.

Puffins are sociable birds, found in the uninhabited portions of our sea coasts, where they deposit their single white egg in burrows. Both male and female assist in incubation. From the burrow containing the downy young the old bird may be removed with the hand, when the nestling is usually found clinging by the bill to the wing or tail feathers of the parent.

\section{MARBLED MURRELET}

Marbled Murrelets, as the name implies, are diminutive murres. There are several varieties, all making their homes on the Pacific Ocean, usually on the islands. Large numbers of this species are observed at Sitka, Alaska, and they inhabit the Aleutian Islands, where they reach their northern limit at their breeding grounds in this chain of remote islands, while the southern range is as far southward as Vancouver Island and the coast of British Columbia. They fly rapidly and swim and dive like a grebe, but seldom alight except in rocky places, where it is possible for them to launch into the air and eventually return to the water, for the legs of these birds are set so far back upon the body as to make them extremely awkward on land.

The eggs are deposited in holes made in the turf or sod overhanging the brow of a cliff. One and sometimes two eggs are laid. 


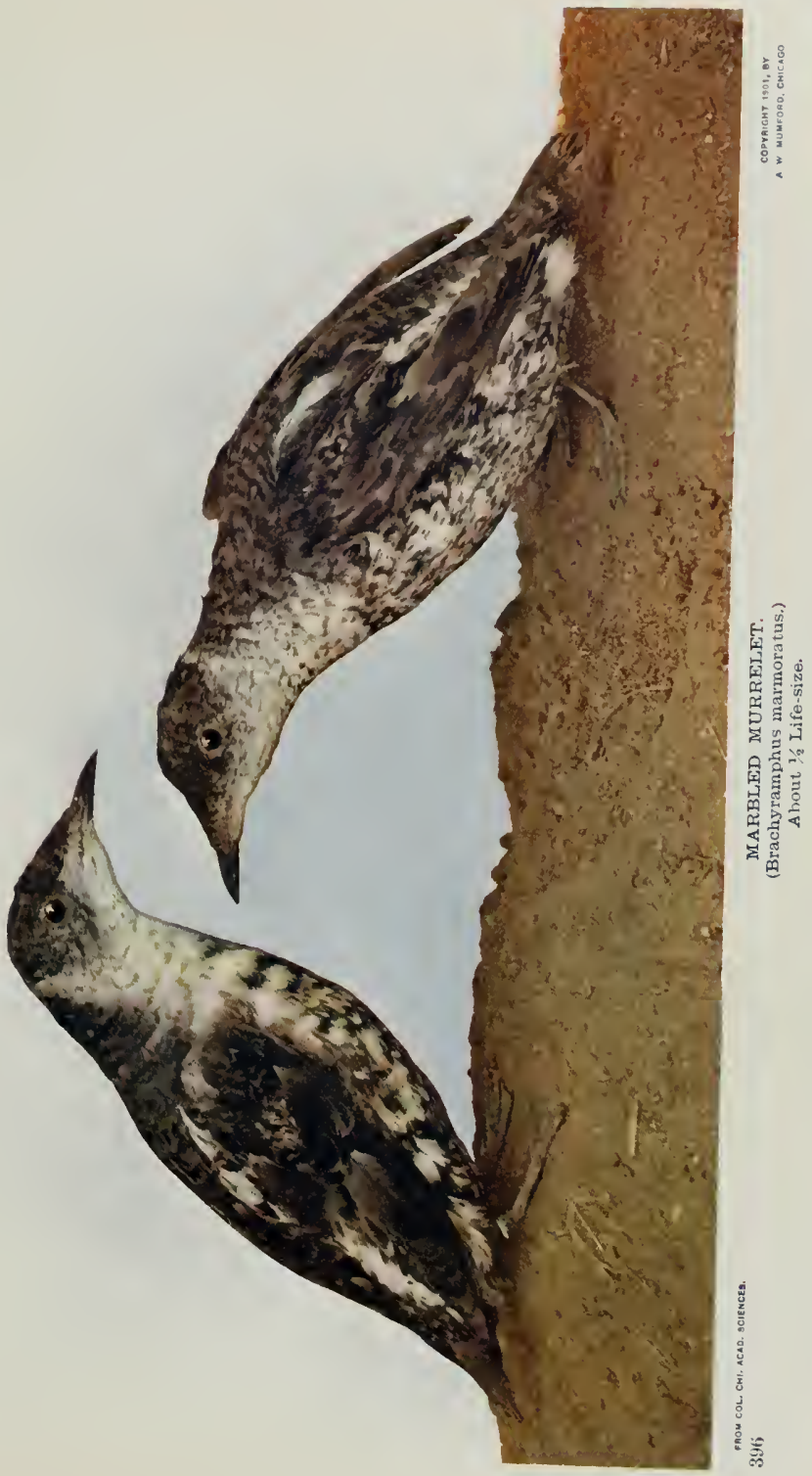





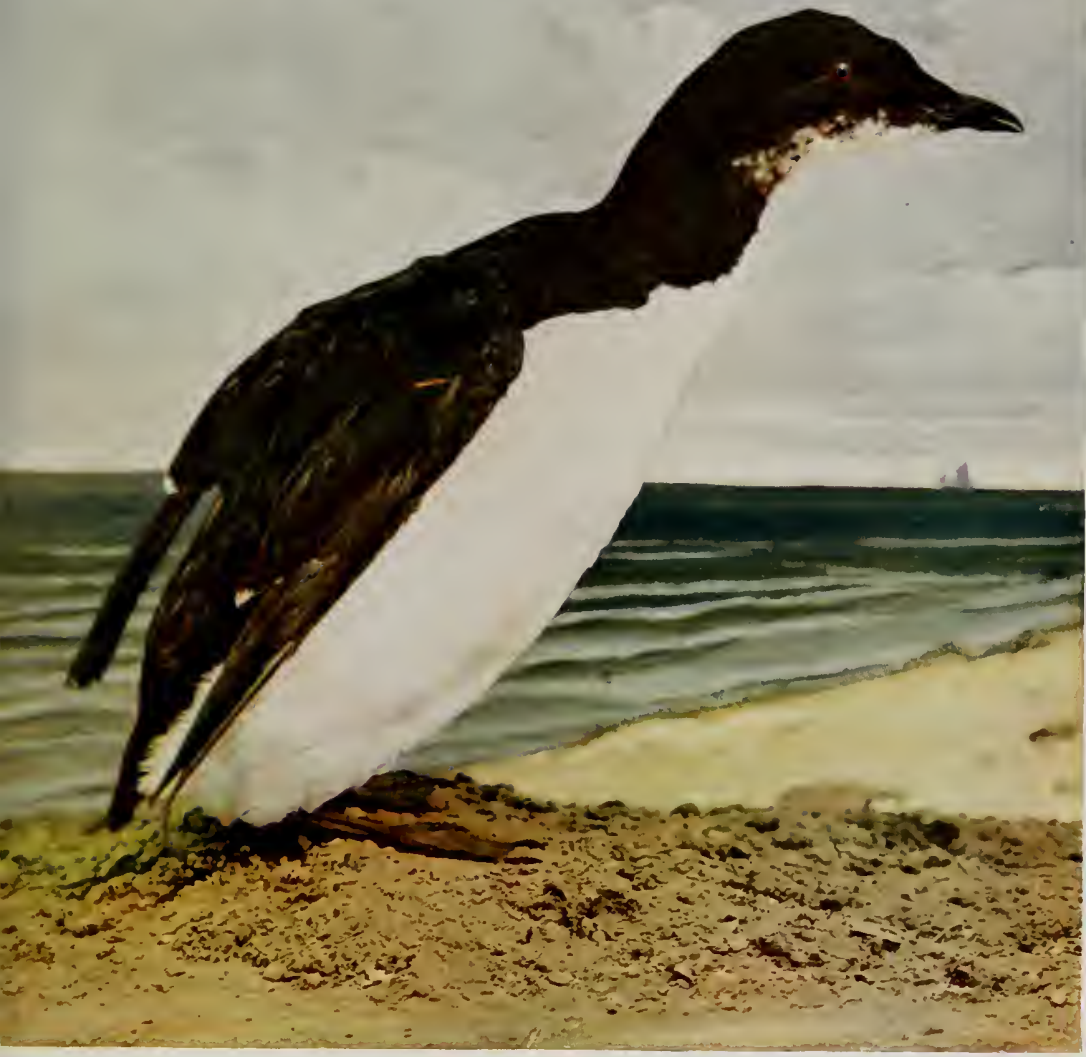





\section{BRUNNICH'S MURRE}

Brunnich's Murre ranges through the islands and along the coast of the North Atlantic and Arctic oceans.

Murres are aquatic birds and, like the auks and puffins, are eminently gregarious. This species is the only variety that reaches the interior of North America, as occasionally specimens are observed on the Great Lakes, where they have evidently strayed out of their course, perhaps have been carried from the sea coast by inclement weather. These birds are found usually on the Atlantic Coast from New York northward to the Arctic regions. Murres inhabit the islands throughout the Arctic Ocean off the coast of Asia and Europe.

In Europe they are robbed of their eggs for food. Each female deposits the single egg on the bare rocks, often without any protection from the elements. The eggs are remarkably well adapted to their surroundings, as they are thick-shelled, long and pointed, so that when disturbed the eggs do not roll off the cliffs, but simply describe the arc of a circle. Hundreds of birds may be found incubating within a radius of one hundred yards, sitting peaceably side by side in their congested quarters.

The eggs show marked variations; some are green with large black markings, others are pure white, still others are yellow with chocolate scrawls. This great variation in coloration may enable each bird to recognize her own egg. Clouds of birds may be seen circling not far from some huge rugged rocks jutting out into the raging sea, while uttering 
a syllable which sounds exactly like "murre," from which they take their name.

'These birds have many natural enemies, among them the various gulls, which have a habit of destroying the eggs whenever the parents are forced to leave them. These beautiful but thieving gulls actually carry these immense eggs in their mouths, flying to some remote part of the island or rocks, where they puncture the shell and derour the contents. In spite of enemies and in spite of the single egg laid, like so many of the diving birds, they maintain their numbers until killed off by man.

\section{DOVEKIE}

The Dovekie, commonly called Sea Dove or Little Auk, is a little fellow with short bill and legs, inhabiting the Atlantic Ocean from the Gulf of St. Lawrence northward. Dovekies probably do not breed south of Greenland; in winter they occur in New Brunswick, Newfoundland, and Labrador, becoming abundant off Exeter Sound and along the west coast of Baffin Bay.

Probably the most accessible breeding grounds are in Iceland. Many European bird lovers find that northerly spot much more accessible than any sinilarly located place to be reached from either side of the American continent. Iceland is a veritable bird paradise. Myriads of gulls, sea ducks, shore birds, and boreal land birds, such as the ptarmigan, gyrfalcon, and finches, haunt the bleak regions of this island. The dovekie deposits her single large palegreenish-blue egg in crevices of the sea cliffs. 


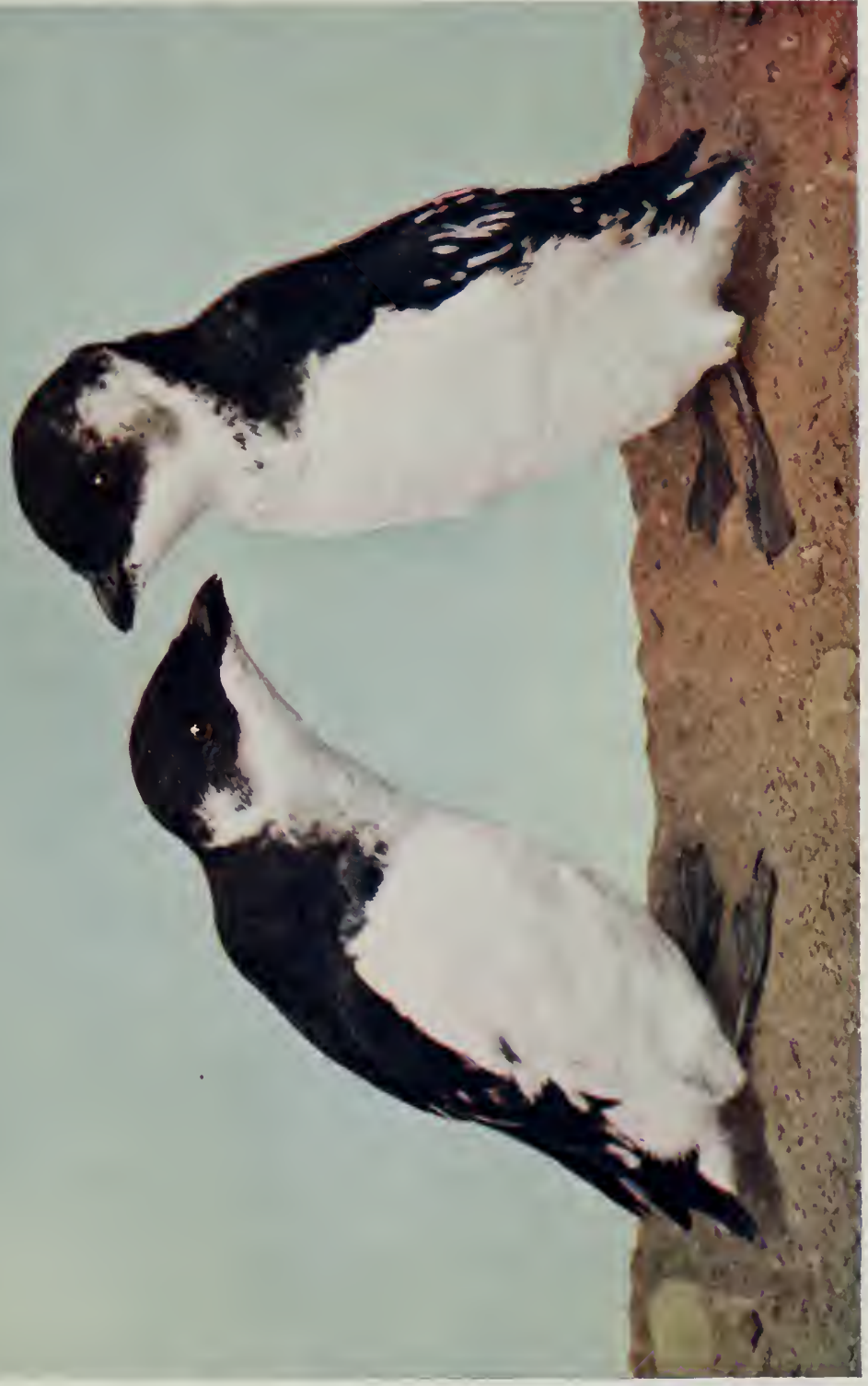

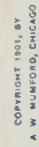

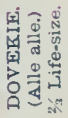




$$
\text { . }
$$




\section{CHAPTER IV}

\section{LONG-TINGED SWIMMERS}

GuLLS and Terns belong to one family; about forty species of the one hundred known are found in North America.

Gulls are maritime and pelagic, though some are found inland. Gulls are larger and stronger than terns, though less graceful and active on the wing. The bills point forward and not downward in flight. They get food largely by skimming it from the surface of the water, or take it from the land, and do not plunge for it, as do the terns. They are largely scavengers, though some feed on small mammals and eggs and the young of other birds. Better swimmers than the terns, they spend more time resting on the water; they nest in colonies, usually on ground, sometimes on rocky ledges, and rarely in trees.

Terns visit the shores of salt and fresh water, especially salt. They are often called sea swallows because of their strong, graceful flight. They plunge after fish; in flight the bills point downward.

The order Tube-nosed Swimmers contain the greatest fliers. Petrels are closely allied to albatrosses, shear-waters, and fulmers. Petrels are pelagic, visiting land only to nest. They are strong, graceful fliers, and are noted for following ships.

Cormorants and Pelicans belong to the order of Totopalmate Swimmers, as all four toes are united by web. The 
cormorants are found in all parts of the world, ten of the thirty species being found in North America. The doublecrested cormorant is the most common in the United States. While usually maritime, some frequent bodies of fresh water. They are gregarious, often breeding in colonies. Fliglit is strong and duck-like, near the surface of the water, except when migrating. They dive for fish from the water, or dive from perch like the kingfisher, but not from the air.

Three species of pelican are found in North America, only one of which is found in the interior. Pelicans are gregarious, nestling in colonies. Their flight is strong but leisurely, several wing strokes being followed by a short sail; all birds of a flock flap wings and sail in unison. The peculiar feature is the large pouch used as a scoop-net in catching fish. Some species plunge for food, while others use the pouch while swimming.

\section{KITTIWAKE}

This medium-sized gull is supposed to take its name from the note, which is the shrill "Kit-ti-wake." Almost exclusively a seagull, we rarely meet with this species on our large inland lakes. They are boreal, and Mr. Peary, our Arctic explorer, found them breeding abundantly on the coasts of Greenland. They are common to the Atlantic waters of both Europe and America. In winter and early spring the cry of the kittiwake echoes along the rocky shore of the New England coast.

They do not nest upon the ground, like most other gulls, but resort to the rocky and almost inaccessible cliffs over- 

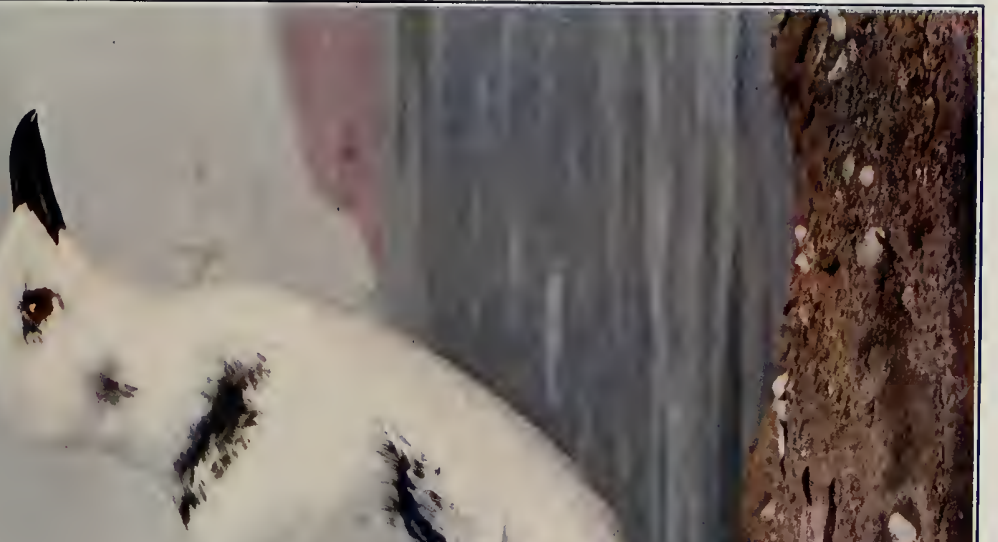
3. $2 x$ as

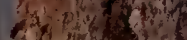

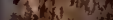
(a) to $x_{1}$ A स. $+3$

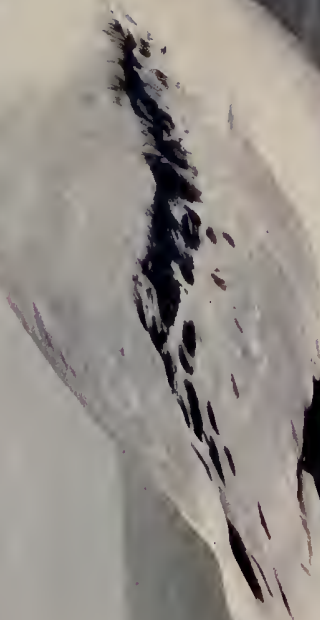

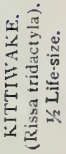
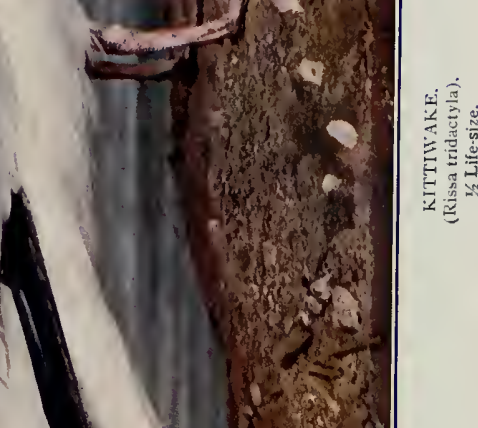

4 a
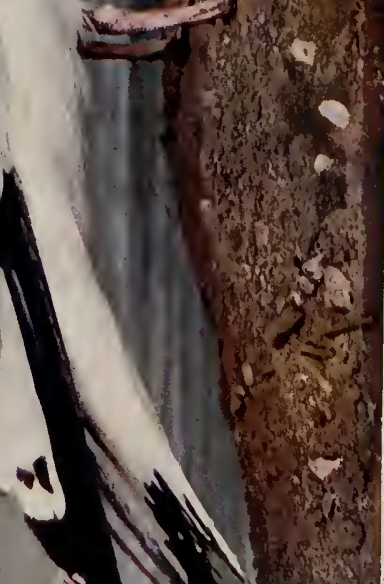

S

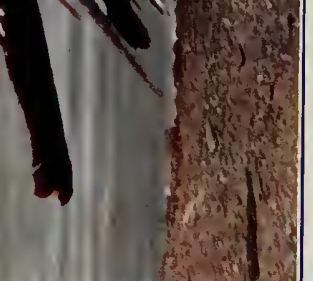




hanging the water. The famous Bird Rocks in the Gulf of St. Lawrence are probably the farthest south these birds breed, constructing substantial nests of grass and seaweed on inaccessible ledges. The ground color of the two or three eggs is yellowish buff or greenish gray marked with irregular spots of brown and lilac.

Frequently the birds nest in very close proximity to each other, resorting annually to the same filthy, guano-covered rocks. The Pacific kittiwake, inhabiting the northern coast of Northern America, breeding in Alaska, is the western form.

\section{THE HERRING GULL*}

The American Herring Gull is found throughout North America, nesting from Maine northward and westward throughout the interior, on the large inland waters, and occasionally on the Pacific; south in the winter to Cuba and Lower California. This gull is a common bird throughout its range, particularly coastwise. Colonel Goss, in his Birds of Kansas, writes as follows of the herring gull:

"In the month of June I found the birds nesting in large communities on the little island adjacent to Grand Ianan; many were nesting in spruce tree tops from twenty to forty feet from the ground. It was an odd sight to see them on their nests or perched upon a limb, chattering and scolding as approached."

The young gulls grow rapidly. They do not leave their nesting grounds until able to fly, though half-grown birds are sometimes seen on the water that by fright or accident have fallen. The nests are composed of grass and moss. 
Some of them are large and elaborately made, while others are merely shallow depressions with a slight lining. Three eggs are usually laid, which rary from bluish-white to a deep rellowish brown, spotted and blotched with brown of different shades. In many cases where the herring gull has suffered persecution it has been known to depart from its usual labit of nesting on the open sea shore.

It is a pleasure to watch a flock of gulls riding buorantly upon the water. They do not dire, as mant suppose, but only immerse the head and neck. Ther are omnirorous and greedy eaters. "scarengers of the beach, and in the harbors to be seen boldly alighting upon the masts and flying about the ressels. picking up the refuse matter as soon as it is cast orerboard."

\section{RING-BILLED GLLL}

The Ring-Billed Gull ranges throughout North America, being more common in the interior.

Of all gulls, not excepting the herring, this bird is the commonest on the inland waters. The berring is more abundant on the Atlantic. The southern portion of the Great Lakes and the Mississippi Rirer from Minnesota southward to St. Louis are the winter haunts of the ringbilled gull. Ther are more commonly found along rivers than formerly, soaring in great numbers about refuse which may be found eren in remote sections, sometimes fifteen to twentr miles from any large bodr of water.

During extremely cold winters the lagoons in our public parks sometimes freeze to the bottom: at the time of the spring thaw these birds feed on the frozen fish which are 


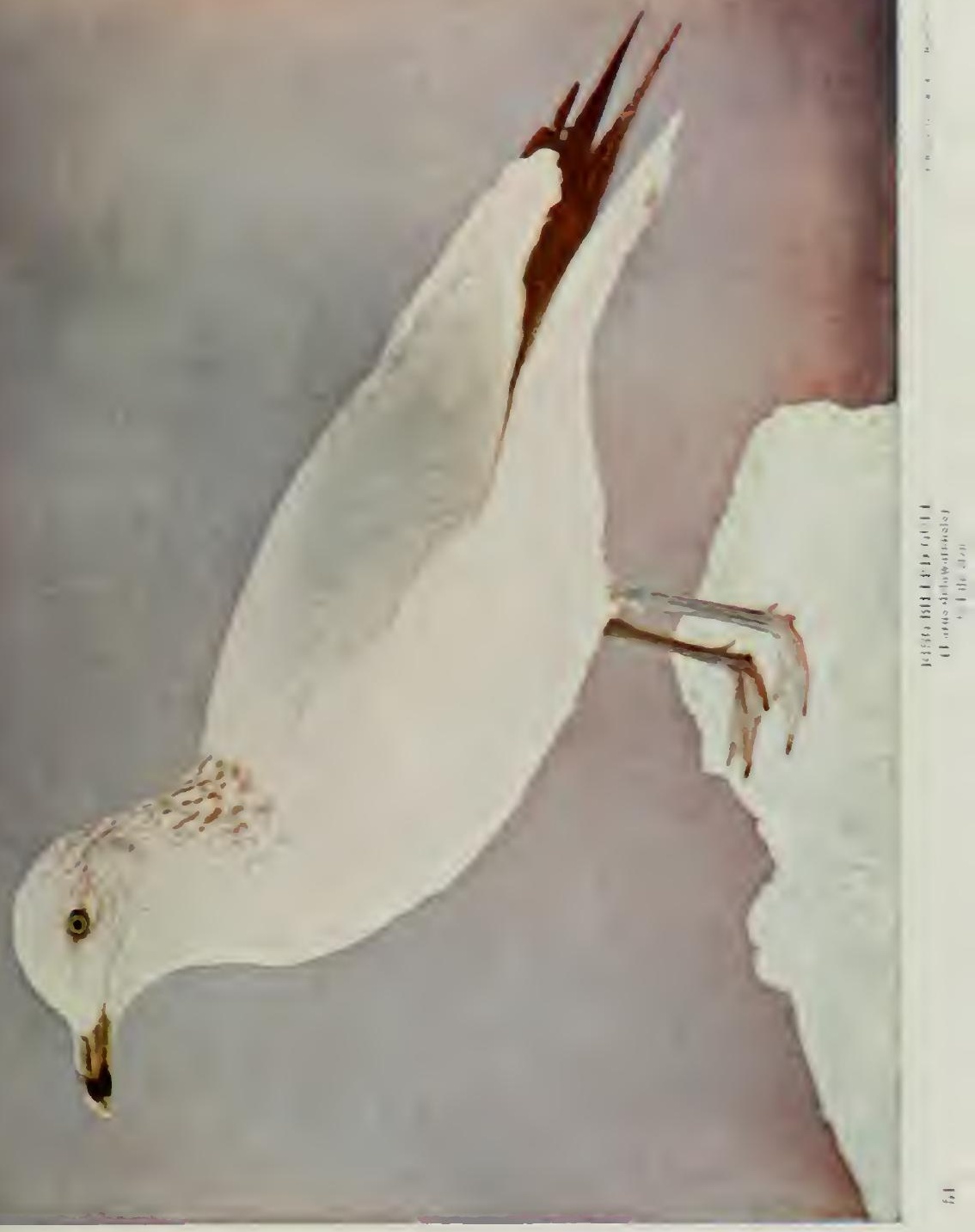





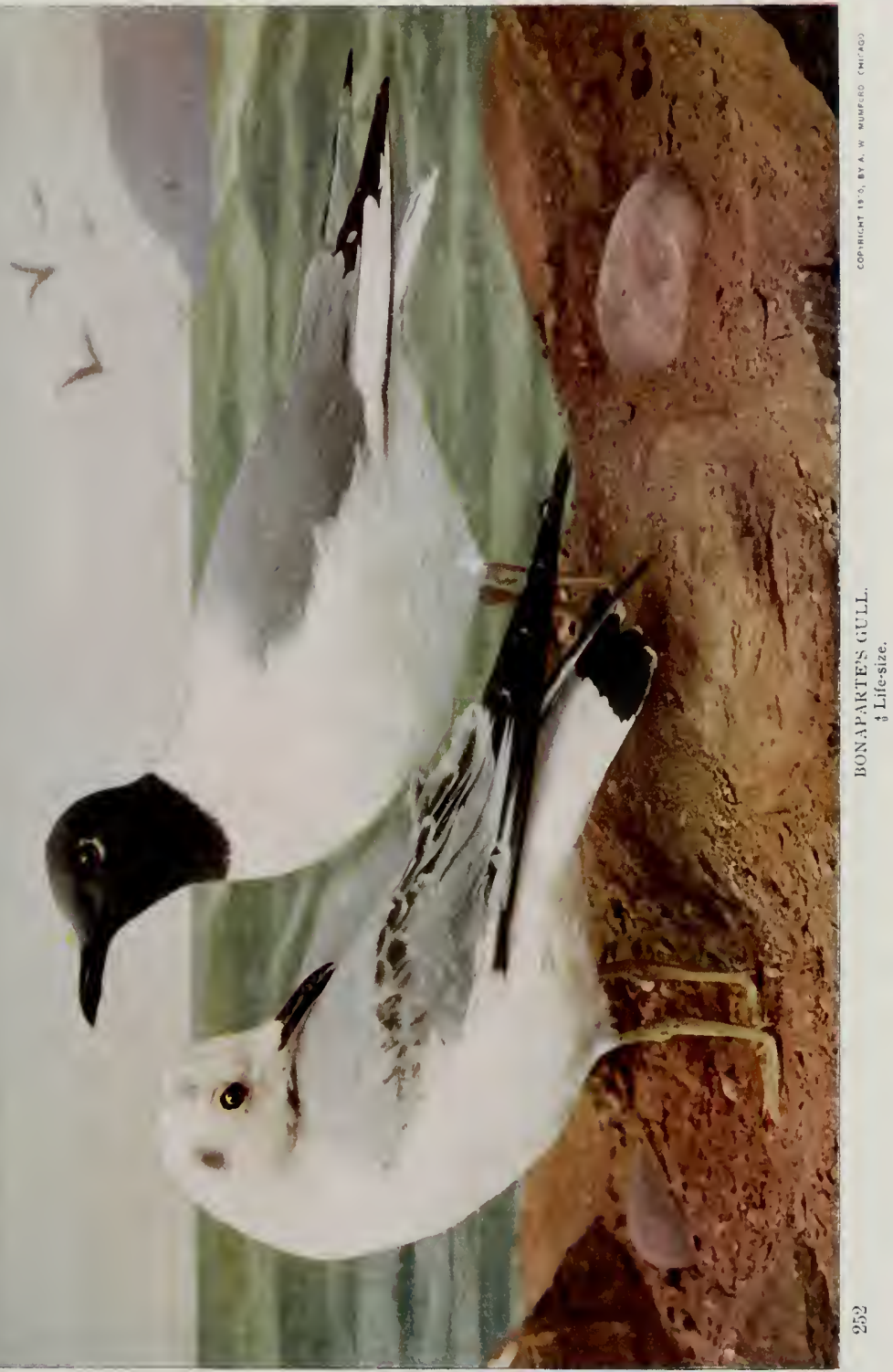



gradually exposed by the melting ice. They frequently rob other water birds, as a nerganser or a grebe. As these divers rise to the surface with a fish, the gull, with a dextrous swoop, seizes his prey and makes off with it. Sometimes the gulls so gorge themselves as to be seen flying away with a half-swallowed fish protruding from the bill. The birds are highly useful as scavengers and destroyers of insects.

Rude nests of hay, sticks, and grass are placed on the ground, usually on islands. Three buff, clay-colored eggs, spotted and blotched with brown, are laid in May.

\section{BONAPARTE'S GULL}

"This pretty little gull claims the whole of North America as its home, although it nests only north of the United States, apparently not quite to the Arctic Circle. This species is often common near streams and small bodies of water, large enough to furnish their food of fish. The three acres of the Oberlin, Ohio, waterworks reservoir, well within the city, is visited each spring by flocks which feed upon the half-domesticated fish found there. I have often seen flocks of twenty or more birds passing over plowed fields during the vernal migration, sometimes even stopping to snatch some toothsome grub from the freshly turned furrow, but oftener sweeping past in that lithe, graceful flight so characteristic of this small gull.

"To the farm boy, shut in away from any body of water larger than an ice-pond, where no ocean birds could ever be expected to wander, the appearance of this bird, bearing 
the wide freedom of the ocean in his every movement, is truly a revelation. It sends the blood coursing hotly through his reins until the impulse to get away into the broader activities of life, to see something of the wide land known to this winged creature, eamnot be put down.

"In flight they progress casily by contimued leisurely wing strokes, each stroke sceming to throw the light body. upward slightly as though it were but a feather's weight. In flight the watchful eye is turned hither and thither in quest of some food morsel. which miy be a luckless fish venturing too near the surface. to be suatehed up by a deft turn of the wings and a sudden stroke of the keen bill. Floating refuse also is gatlered from the surface of the water while the bird is resting.

"It is only in the breeding plumage that this gull wears the slaty. plumbeous hood. It seems doubtful if the birds obtain the hood until the second or third year, when they are fully adult. But in any plumage there are some dark spots about the head.

"The nest is placed in bushes, trees, or on high stumps, and is composed of sticks and grasses. with a lining of finer vegetable material. The three or four eggs have the grayish-brown color, spotted and blotehed with browns, which is characteristic of this group of gulls."

LYNDS Joxes.

\section{CASPIAY TERI}

The Caspian Tern is the largest of the terns, and is readily reeognized by the enral-red bill. Birds of wide range. they are extremely sociable. and not only nest in colonies. but 

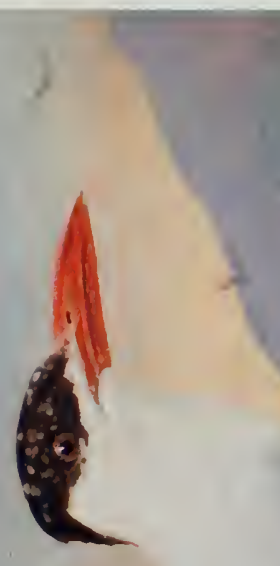

frequently in company with other long-winged swimmers, such as the herring gull or California gull. The Caspian terns frequently migrate at great heights and far from land, a course which they may pursue when traveling to thcir breeding grounds on the Atlantic or upper Lake Michigan, and thus their presence is little suspected by the casual observer in the Middle States.

Until the Audubon Societies patrolled many of the islands lying off the American coast or on the large inland lakes the eggs of the Caspian tern were used for commercial purposes. Fishermen gathered them in great quantities, and the birds, loath to leave their favorite islands, would continue laying well into the summer months, until they finally became discouraged and would move to another locality.

These birds present a beautiful sight as they circle over their eggs at the approach of some intruder, uttering their hoarse cries. Though web-footed and with an oily texture to the plumage, the birds seem more fond of flying than swimming. Their food consists of insects captured in the air and small fish which they capture by diving into the water while flying low over the surface.

During the last eight year's the birds have greatly increased in numbers through rigid enforcement of the plumage law forbidding the selling in America of feathers of native birds. Several large colonies of Caspian terns appear on the islands in the Gulf of Mexico. Other colonies have taken possession of the islands on fresh water lakes in Oregon. The eggs are usually deposited in small hollows on the beach just above high-water mark. No attempt at 
nest-building is made. Two or three clay-colored eggs are laid, thickly spotted with brown of varying shades.

\section{THE FORSTER'S TERN *}

The range of Forster's Tern may be considered as covering North America in general, "breeding from Manitoba southward to Virginia, Illinois, Texas, and California." In winter it passes southward into Central America and to Brazil. It is the common tern of the Mississippi Valley and is quite abundant on the larger inland waters as far north as Manitoba. It is far from common along the Atlantic Coast, excepting at Cobb's Island, Virginia, where it breeds in numbers, though the individuals of this species were not as numerous as were those of the common or Wilson's tern.

In appearance, as well as in its habits, Forster's tern resembles the common tern. The two species may, however, be distinguished by the color of the outer tail feathers, those of Forster's tern having the inner webs darker colored than the outer webs, while the reverse is characteristic of the same feathers in the common tern. The two species may also be distinguished when on the wing by the peculiar grating note of the Forster's tern, the sound of which has been likened by Dr. Ridgway to the "sonorous qua-a-a of the logger-head shrike."

Forster's tern breeds in colonies and also in company with other terns and with gulls. Its nest, of flags and various water plants, is usually built in grassy marshes. The old birds are very watchful and carefully guard their nests, eggs, and offspring. When disturbed at their nests they 


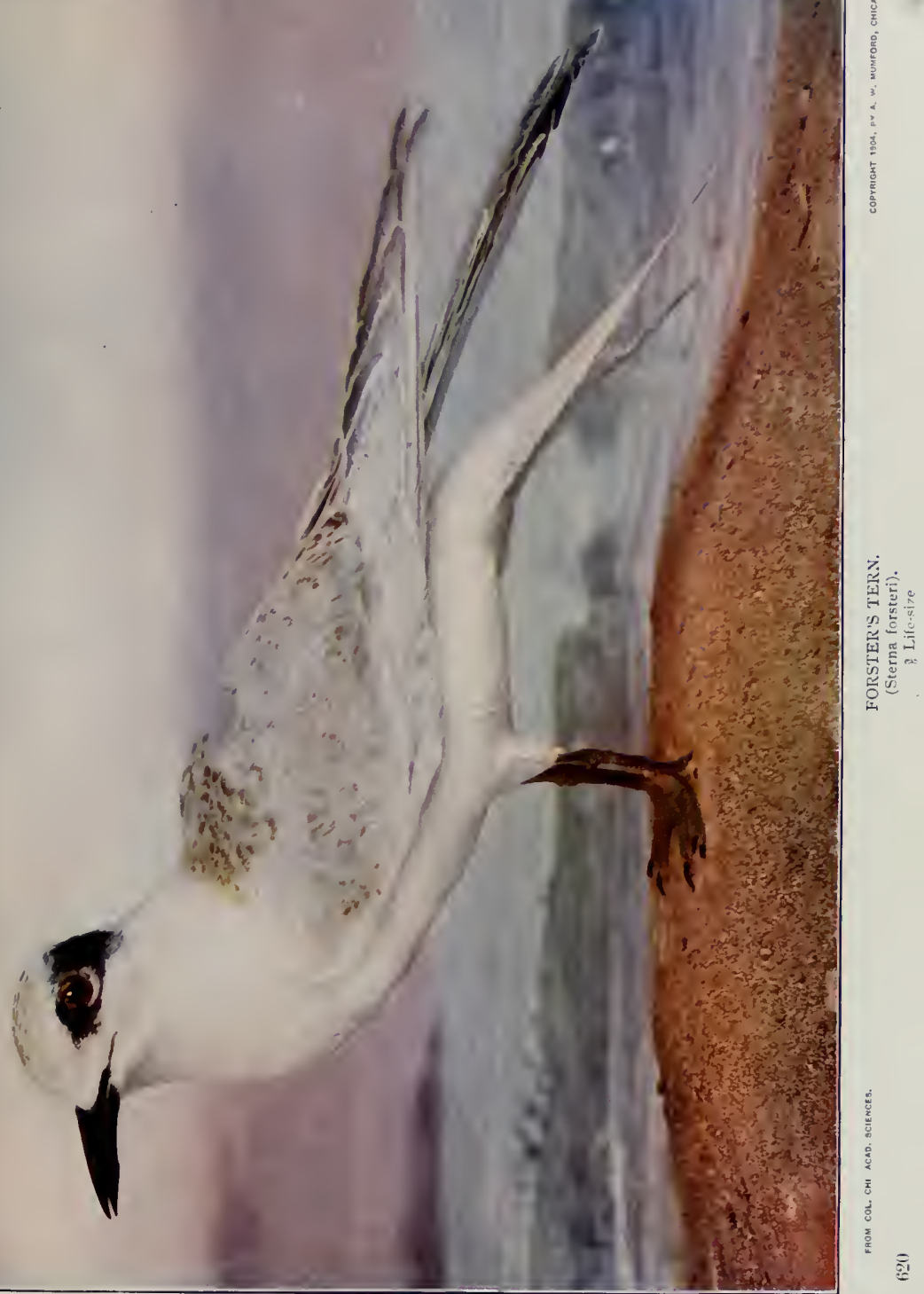





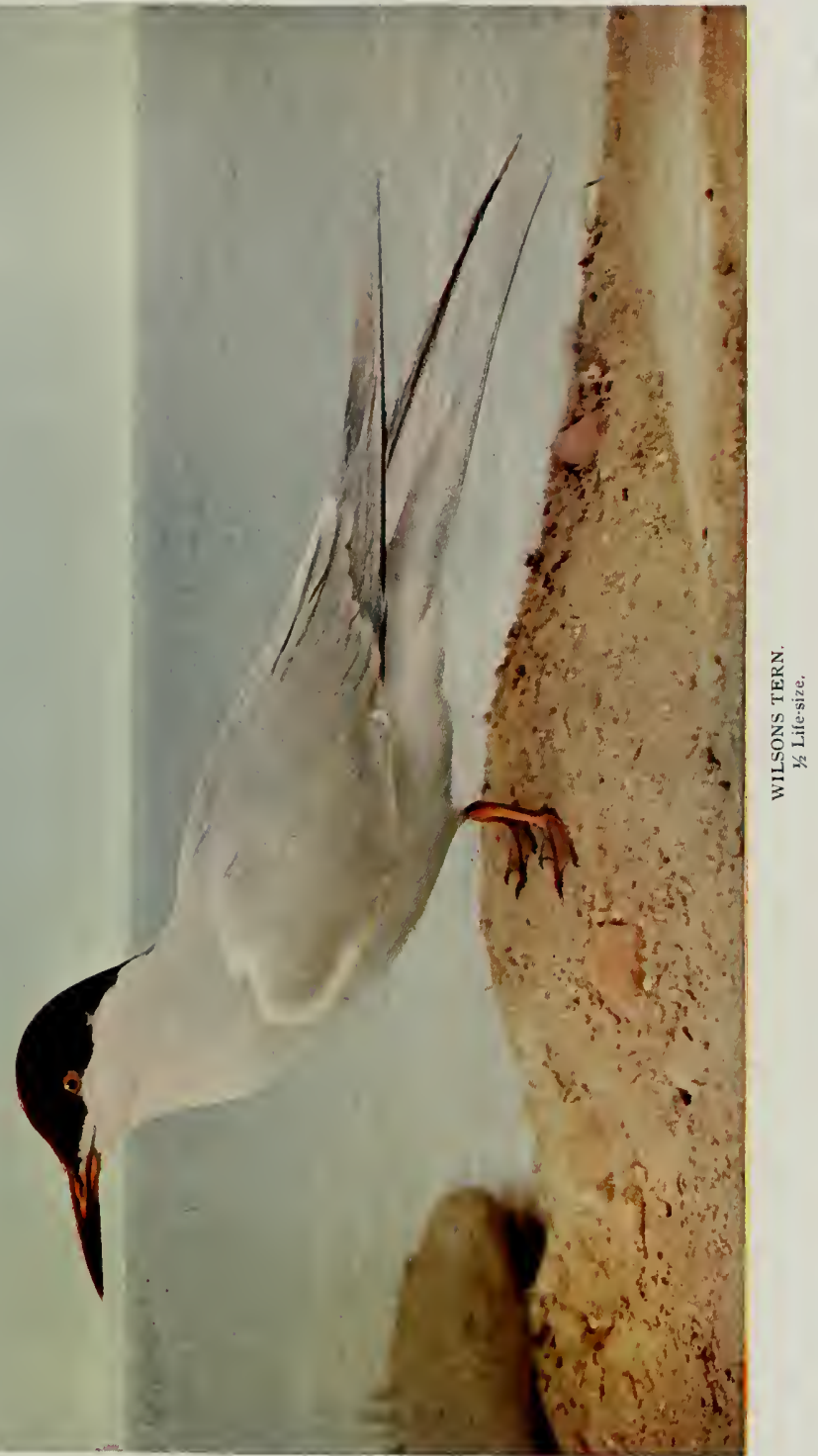



become very noisy, " uttering a grating, monotonous note." It is said that at times, in their frenzy they fly at an intruder, often approaching very close to his head.

In the winter the plumage of this beautiful tern shows a decided change. The head becomes white, more or less spotted with black; the eye is enclosed by a large black area; the bill becomes black and the feet brownish.

\section{COMMON TERN}

The Common Tern, often called Wilson's Tern, sea swallow, red shank, summer gull, and mackerel, is often confused with arctic tern and Forster's tern. This beautiful little sea swallow was first reported by Wilson, one of our earliest ornithologists. Formerly abundant, this bird is now threatened with extinction unless protected from plumage and egg hunters. These terns perform extensive migrations, passing the winter months on the coasts of South America, often far below the equator. In summer they may be found breeding on the islands of the Great Lakes in company with herring gulls and Caspian terns.

The birds are as agile on the wing as our barn swallow, and capture many flying insects. They also feed upon marine life, but refrain from playing the role of scavenger, leaving the gulls to derour any decaying animal matter.

Hundreds of terns may be found nesting together, depositing their three eggs in a carelessly constructed nest of dry grasses on the pebbly beach or rocky projections just above high-water mark. Quite a commotion prevails when the naturalist intrudes upon their breeding grounds; the 
birds rise like a clond and fly about in majestic circles, screaming persistcntly until the trespasser leaves.

Early in June three eggs are laid, varying greatly in shape and color; the background is light green, buffy or drab, spotted and blotched with various shades of brown and lilac. The young are able to care for themselves as soon as hatched.

\section{BLACK TERN}

The Black Tern, the only dark-plumaged member of the gull or tern family inhabiting the interior portions of North America, breeds from the Gulf of Mexico to upper Canada and from the Atlantic to the Pacific coast, nesting even within the corporate limits of Chicago.

While gregarious, they are found in smaller groups than most of our long-winged swimmers. Largely insectivorous, they capture their prey in the air. They also plunge into the water after small minnows and other marine life. Although the feet are webbed, these birds seldom swim, except, perhaps, when migrating across large bodies of water. Their call note is a harsh shriek, uttered incessantly if one intrudes upon their nesting sites, usually in marshy' places, preferably open country free from timber.

The nests are constructed of decayed vegetation, dead flags, and rushes, often a mere depression on a partially submerged muskrat house, containing two or three darkyellowish eggs, heavily and thickly blotched with shades of lilac and very dark brown. These birds have a habit of rolling their eggs in the wet earth and vegetation, thereby rendering them less conspicuous. I have known the birds 


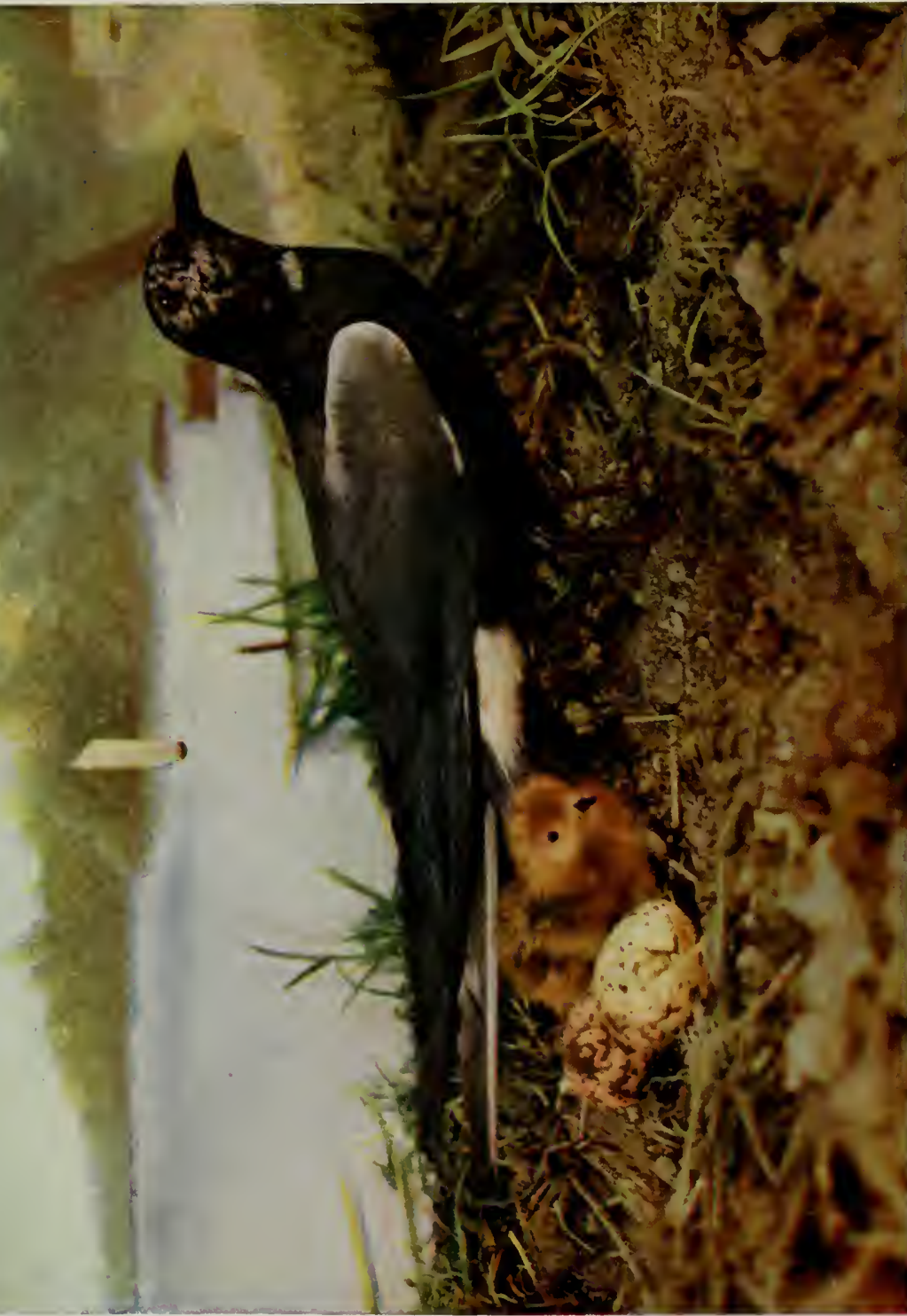

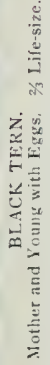





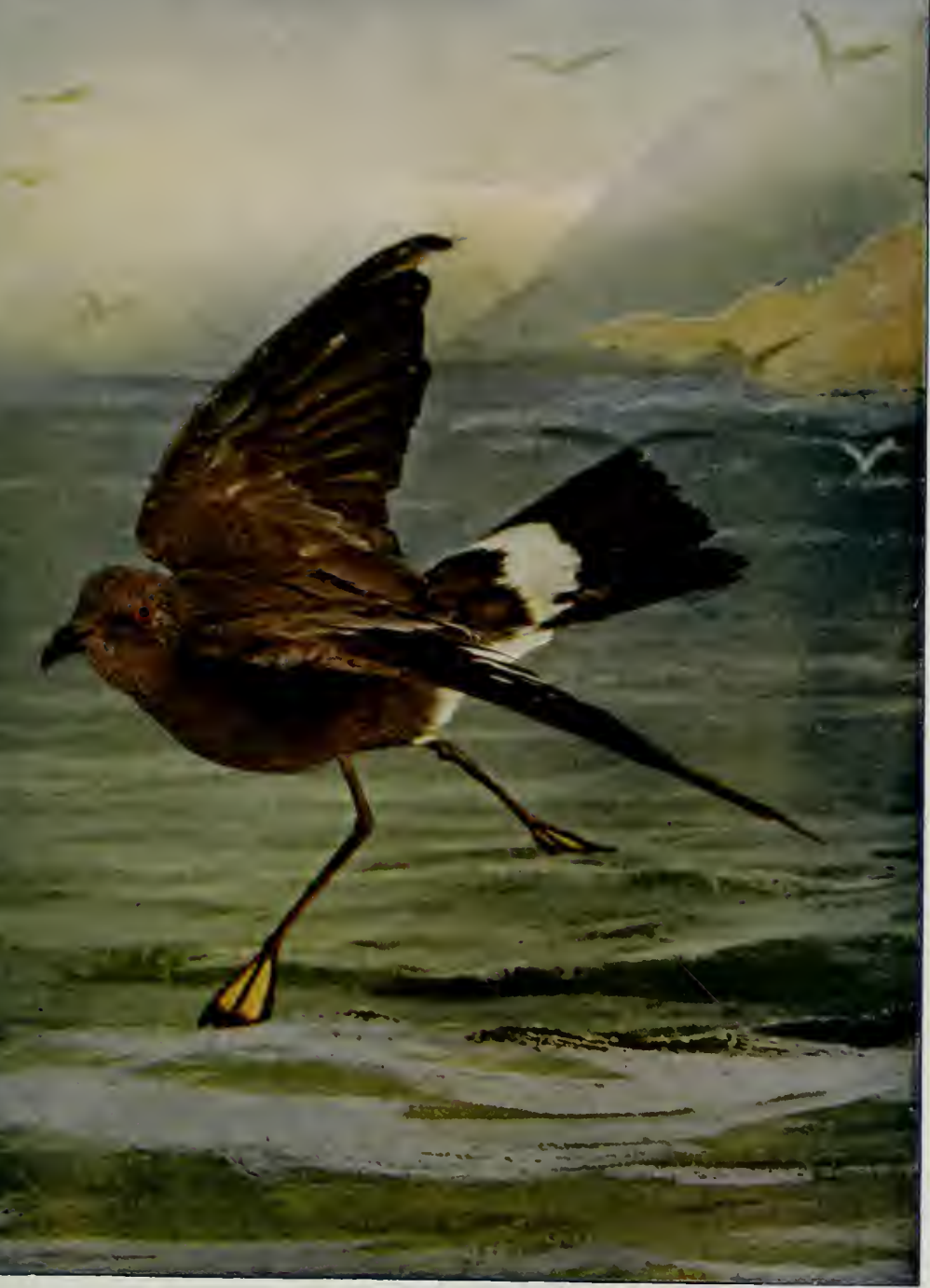

WILEONS PETREL.

万ै Life-size, 

to arrange a little nest on the top of an old grebe's nest. Often the water is sereral fect deep where the nests are made, but the growing reeds and rushes allow the water to remain more or less stagnant, so the eggs are seldom disturbed by waves.

\section{WILSON'S PETREL}

The sailors have always harbored a friendly feeling for these sea-loving birds. They tell you that Mrs. Carey lives on the edges of the seas and the petrels are her chickens, hence they are frequently called Mother Carey's chickens.

Two species of petrel are common to the North American coast. Probably at least a dozen other forms have been recorded on our continent, as the petrels are great wanderers and frequently stray out of their course. The feet are webbed and the wings are long and powerful. The flesh is so oily that the plucked body of a petrel, supplied with a wick similar to that of a candle, will burn for over an hour.

Petrels feed from the surface of the water, picking up food while swimming or while on the wing. They seem to delight in following ressels at sea to pick up the refuse matter thrown overboard as they fly close to the water. They also follow the breakers, often seizing an unfortunate crab or crawfish that is cast up by the wares.

Wilson's petrel resorts to islands in the Southern Hemisphere during the breeding season. The single white egg, sometimes faintly wreathed with dull lavender, is incubated at the end of a three-foot burrow. The tube-nosed swim- 
mers lay but a single egg. When disturbed on their nests they emit an oily substance from their crops very disagreeable to the intruder.

\section{THE YELLOIV-BILLED TROPIC BIRD*}

In appearance this bird resembles a large tern and its habits are similar to those of the terns. Intertropical, it is of a wandering disposition, breeding on the islands of midocean thousands of miles apart. It is noted for its elegant, airy, and long-protracted flight. Davie says that on Bourbon, Mauritius, and other islands east and south of Madagascar it breeds in the crevices of the rocks of inaccessible cliffs and in hollow trees. In the Bermuda Islands it nests about the first of May in holes in ligh, rocky places along the shores. Here its favorite resorts are the small islands of Great Sound, Castle Harbor, and Harrington Sound. The Phaeton, as it is felicitously called, nests in the Bahamas in holes in the perpendicular faces of cliffs and on the flat surfaces of rocks. A single egg is laid, which has a ground color of purplish-brownish white, covered in some specimens over almost the entire surface with fine reddish chocolate-colored spots.

These species compose the small but distinct family of tropic birds and are found throughout the tropical and subtropical regions of the world. Long journeys are made by them across the open sea, their flight when emigrating being strong, rapid, and direct, and immense distances are covered by them as they course undismayed by wind or storm. In feeding, Chapman says, they course over the water, beating 


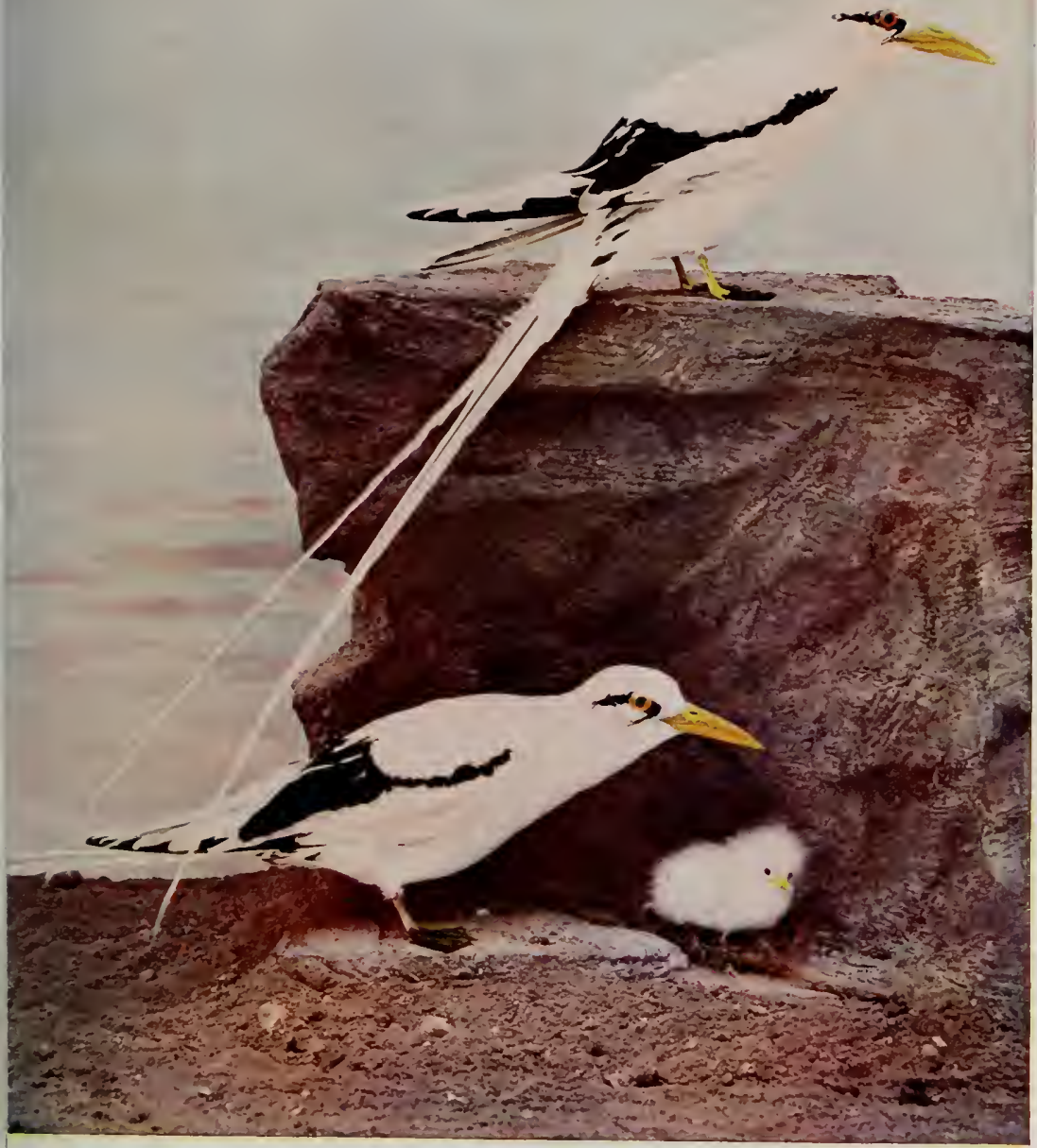





$$
R
$$



back and forth at a height of about forty feet, and their long, willowy tail feathers add greatly to the grace and beauty of their appearance when on the wing. They are of rare and probably accidental occurrence on our coasts.

\section{THE ANHINGA OR SNAKE BIRD*}

The Snake Bird is very singular, indeed, in appearance, and interesting as well in its habits. Tropical and subtropical America, north to the Carolinas and southern Illinois, where it is a regular summer resident, are its known haunts. Here it is recognized by different names, as Water Turkey, Darter, and Snake Bird. The last mentioned seems to be the most appropriate name for it, as the shape of its head and neck at once suggest the serpent. In Florida it is called the Grecial Lady; at the mouth of the Mississippi, Water Crow, and in Louisiana, Bec a Lancette. It often swims with the body entirely under water, its head and long neck in sight like some species of water snakes, and has no doubt more than once left the impression on the mind of the superstitious sailor that he has seen a veritable sea serpent, the fear of which led him to exaggerate the size of it.

As a diver the snake bird is the most wonderful of all the ducks. Like the loon, it can disappear instantly and noiselessly, swim a long distance, and reappear almost in an opposite direction to that in which naturally it would be supposed to go.

The nests of the anhinga are located in various places, sometimes in low bushes at a height from the ground of 
only a few feet, or in the upper branches of high trees, but always over water. Though web-footed, it is strong enough to grasp tightly the perch on which it nests. This gives it a great advantage over the common duck, which can nest only on the ground. Sometimes snake birds breed in colonies with various species of herons. From three to five eggs, bluish or dark-greenish white, are usually found in the nest.

\section{DOUBLE-CRESTED CORMORANT}

Cormorants, sometimes called water turkeys, are similar in construction to our pelicans, but the loose skin on the throat is comparatively inconspicuous, while the pelican has a pouch capable of great distension. The sea coast of America, particularly the Pacific, is the home of many cormorants of several varieties, but the double-crested is practically the only inland species, occurring from Illinois and Iowa northward into Canada during the breeding season. They are gregarious at all times, even nesting in colonies. Twenty-five years ago this large bird appeared in the river bottoms of the Illinois, but the timid creatures retire at the encroach of civilization. Cormorants have all four toes connected by a continuous web. The tail feathers are long and stiff, and the birds use this appendage in progressing underneath the water, where they capture fish. Like ducks, the cormorants in flight extend the neck and legs to their full length.

Of the thirty varieties of cormorants inhabiting the globe, one-third are American. When disturbed the cormorants fly at low altitudes, usually over the water. Their 




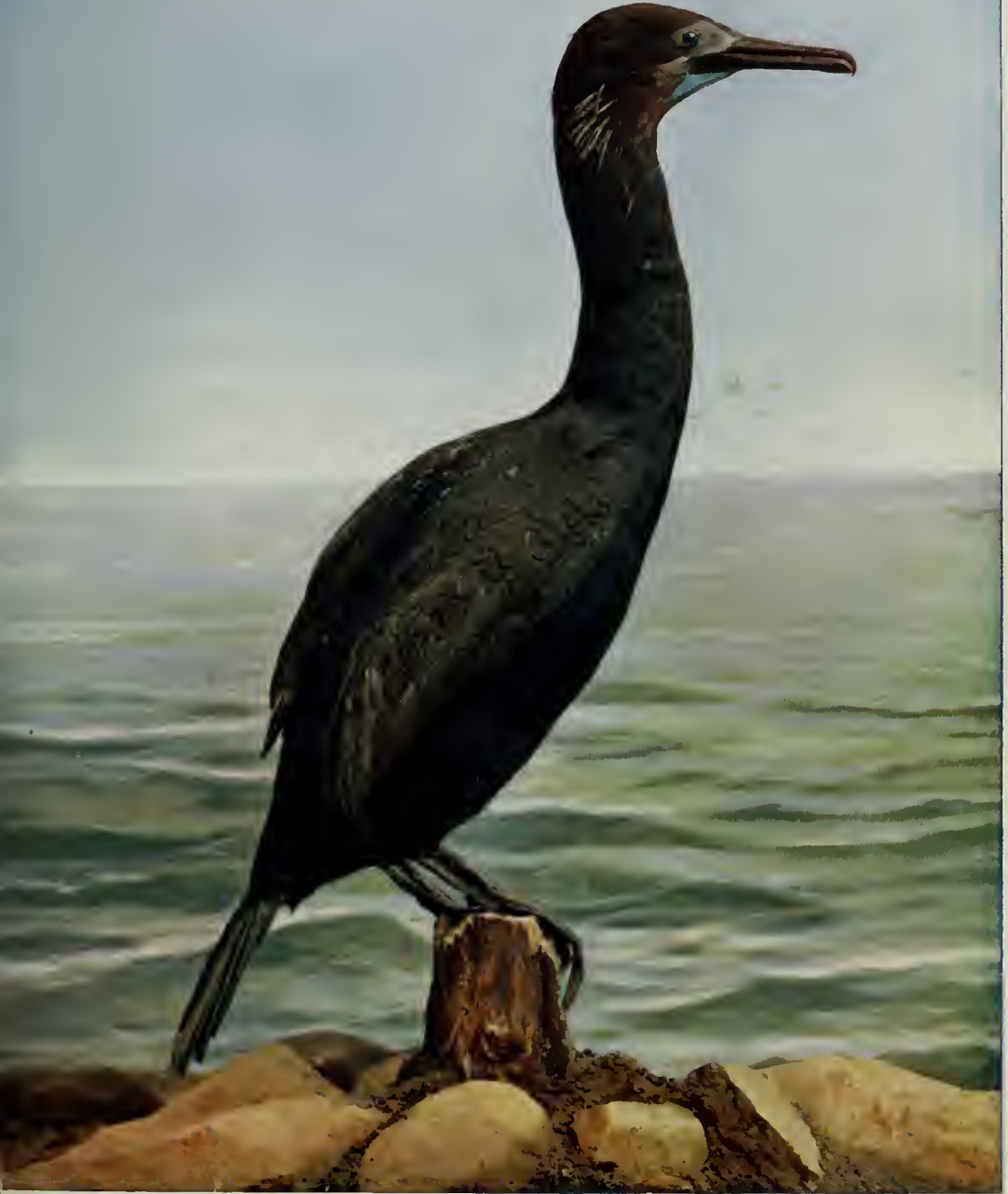



bills are strong and decidedly hooked; this assists them in holding their prey. Unlike the gannets, cormorants do not dive from the air, but from the water or a low perch.

On the barren islands of Devil's Lake, North Dakota, the double-crested cormorant still nests in company with the ring-billed and herring gulls, Canada goose and white pelican. These islands are a paradise for the bird student. On approaching these densely populated areas the wary cormorants are the first to leave their nests. No sooner do they vacate their posts than the thieving gulls descend upon their nests and destroy their eggs.

Cormorants incubate in relays and never vacate their nests except at the approach of man. In Canada, nests are frequently constructed in rocky places overlooking the water. The nests are of sticks, and contain from three to five chalky eggs with a covering showing faint blue.

\section{BRANDT'S CORMORANT}

Brandt's Cormorant, the bird of our illustration, is found on the Pacific Coast from the State of Washington southward to Cape St. Lucas, at the southern extremity of Lower California. In its habits it is gregarious and collects in great numbers wherever its natural food of fish is plentiful. These flocks present a very odd appearance, and their long necks appear as numerous black sticks on the watery background.

The nests are nearly circular when placed on top of the rocks, and are usually constructed of eel grass. They are generally placed in the most inaccessible places and 
at various heights above the surface of the water. The cormorants frequent the same locality from year to year, and experience considerable difficulty in constructing their nests because of the gulls, which frequently carry away the material as fast as it can be gathered. The young, when first hatched, are entirely devoid of plumage, and their skin resembles a "greasy, black kid glove." It is said that the gulls feed upon these young birds.

Mr. Frank M. Woodruff relates the following observations, made during a recent trip to California. He says:

"The Brandt's cormorant is the common species wintering in southern California. Like the California brown pelican and the surf ducks, only the juvenile birds are found in the bay close to the city of San Diego. The birds are perfect gluttons, and as I lifted it into the boat there dropped from the gular sack of one specimen that I shot over twenty small fish. The beautiful iridescence of the dark copper-green plumage of the adult cormorant can only be appreciated when the freshly killed bird is seen."

Seth Mindwell.

\section{WHITE PELICAN}

This bird is common to entire temperate North America. It is one of the largest of our waterfowl, inhabiting both fresh and salt water. Like the brown pelican, this species is decidedly gregarious. Professor Jones says: "The birds travel sixty miles to catch fish for themselves and young. They often vomit up the contents of their stomachs on the ground, where it quickly decays." The stench of the rookeries is almost intolerable. 


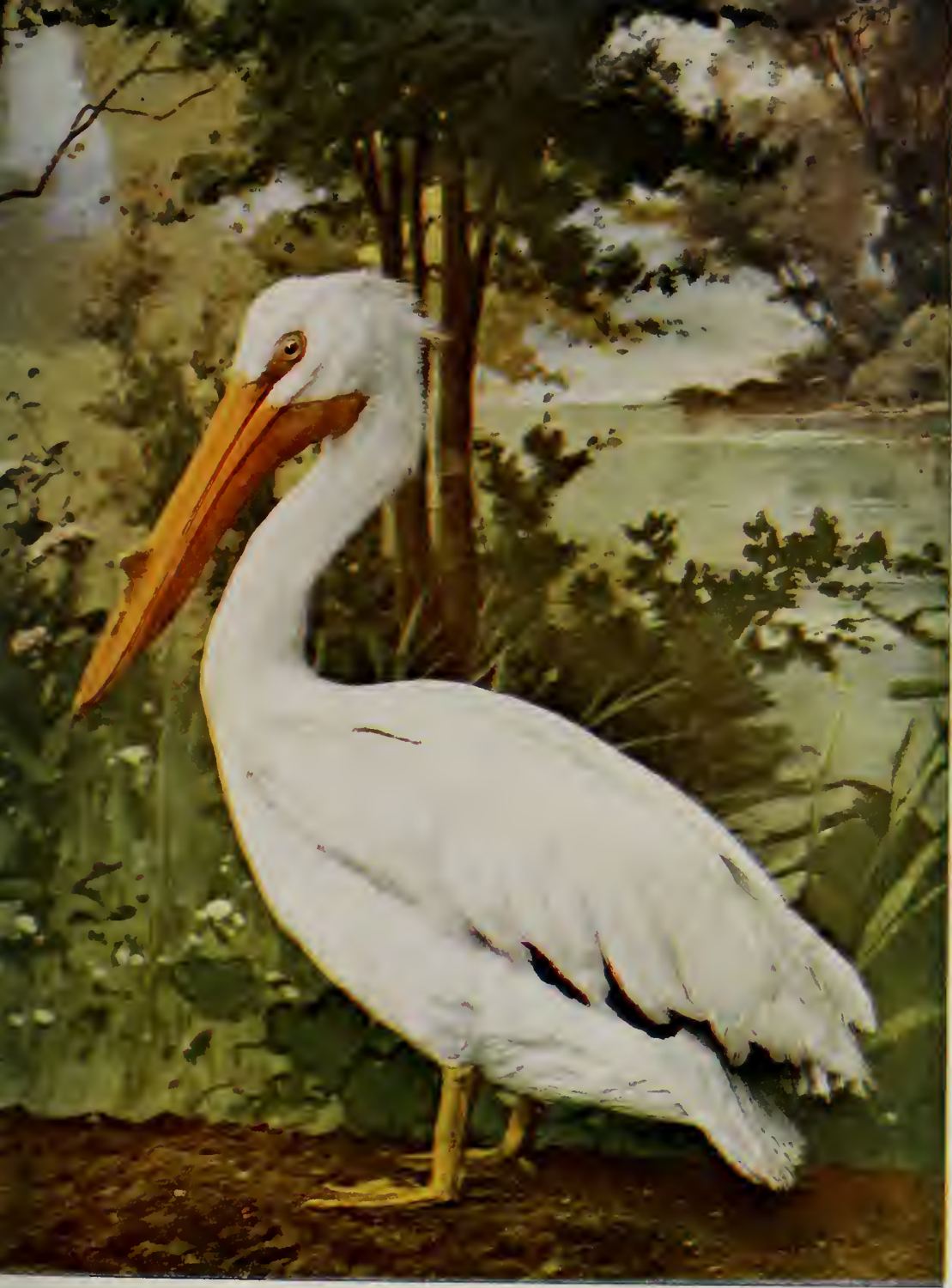



These birds summer at Great Salt Lake, Utah, and on several of the large inland lakes of Oregon. I noted a colony of approximately seventy-five birds at Sweetwater Lake, North Dakota. These are probably the only colonies which remain in the United States proper. Shoal Lake, Manitoba, is one of their farorite nesting and breeding grounds.

The flight of the pelican is picturesque. Being heary birds, they rise from the water with difficulty, using their feet in ascending. A flock of perhaps twenty-five birds will mount into the air during the heat of the day and circle about until they appear like mere specks against the sky.

The plumage of the adult birds is pure white with the exception of a portion of the wing which is black, which color shows in marked contrast when the birds are soaring.

Two or three eggs are deposited in a large, bulky nest of grass, sticks, and rubbish. The thick, white shells have a chalky texture, but are soon stained with nesting material. 



\section{CHAPTER V}

DUCKS AND GEESE

WE have three classes of ducks. The Mergansers, or Shelldrakes, are fish ducks. Both the upper and lower mandibles are deeply notched with barbs, which enable the birds to capture fish while swimming with great rapidity beneath the surface of the water.

Fresh Water, or Pond and River, Ducks possess broad strainer bills, and the fourth or hind toe is without any lobe. These are the mallard, teal, shoreller, baldpate, pintail, wood duck, gadwall, and black duck. This family feed or dip in shallow water or wade about the margins of pools and ponds. They are all game birds, and are more edible than the deep-water ducks.

Sea, or Deep-water, Ducks have a conspicuous flap on the hind toe. While possessing a strainer bill, they feed less upon vegetable life than the pond ducks, and are partial to small fish and other marine life. They occur both on the coasts and in the interior. The redhead, canvas-back, scaup, bufflehead, old squaw, harlequin, eider, scoters, and ruddy ducks are all classed as sea ducks. The speculum, the bright feathers on the wing, is the same for all seasons and all ages of the same kind of ducks.

Geese are larger than ducks, and more graceful upon land. They also differ from the ducks because the plumage of geese is practically the same in both sexes. 


\section{RED-BREASTED MERGANSER}

The Red-breasted Merganser ranges throughout the northern part of North America, breeding from northern Illinois and New Brunswick to the Arctic regions, wintering from southern United States to Cuba.

The red-breasted merganser inhabits Europe, Asia, and America, breeding on the British Isles, Iceland, Greenland, Labrador, Alaska, and the Magdalen Islands in the North Atlantic. During the fall, winter, and spring months they frequent the waters of northern Illinois and Indiana; in March and April they resort to the lagoons of Lincoln Park, Chicago, and feast upon fish, exhibiting at times but little fear of man. The bold, venturesome gulls lurk about the lagoons, and when a merganser arises with his prize, a gull swoops down and in the twinkling of an eye robs the duck of his morsel. The three mergansers, the red-breasted, American, and hooded, generally known as fish ducks, shelldrakes, or sawbills, frequent swift running streams, ponds, and lakes, where they feed almost exclusively upon fish, which they pursue and capture under water. Their deeply barbed bills are especially adapted for catching and holding fish, which the birds bring to the surface before swallowing.

The legs of all fish ducks are placed far back on the body, enabling their owners to outswim the other ducks. They frequently rest upon logs and stumps of trees found in or near the water. The hooded mergansers are the only sawbills whose flesh is at all palatable, and they are 


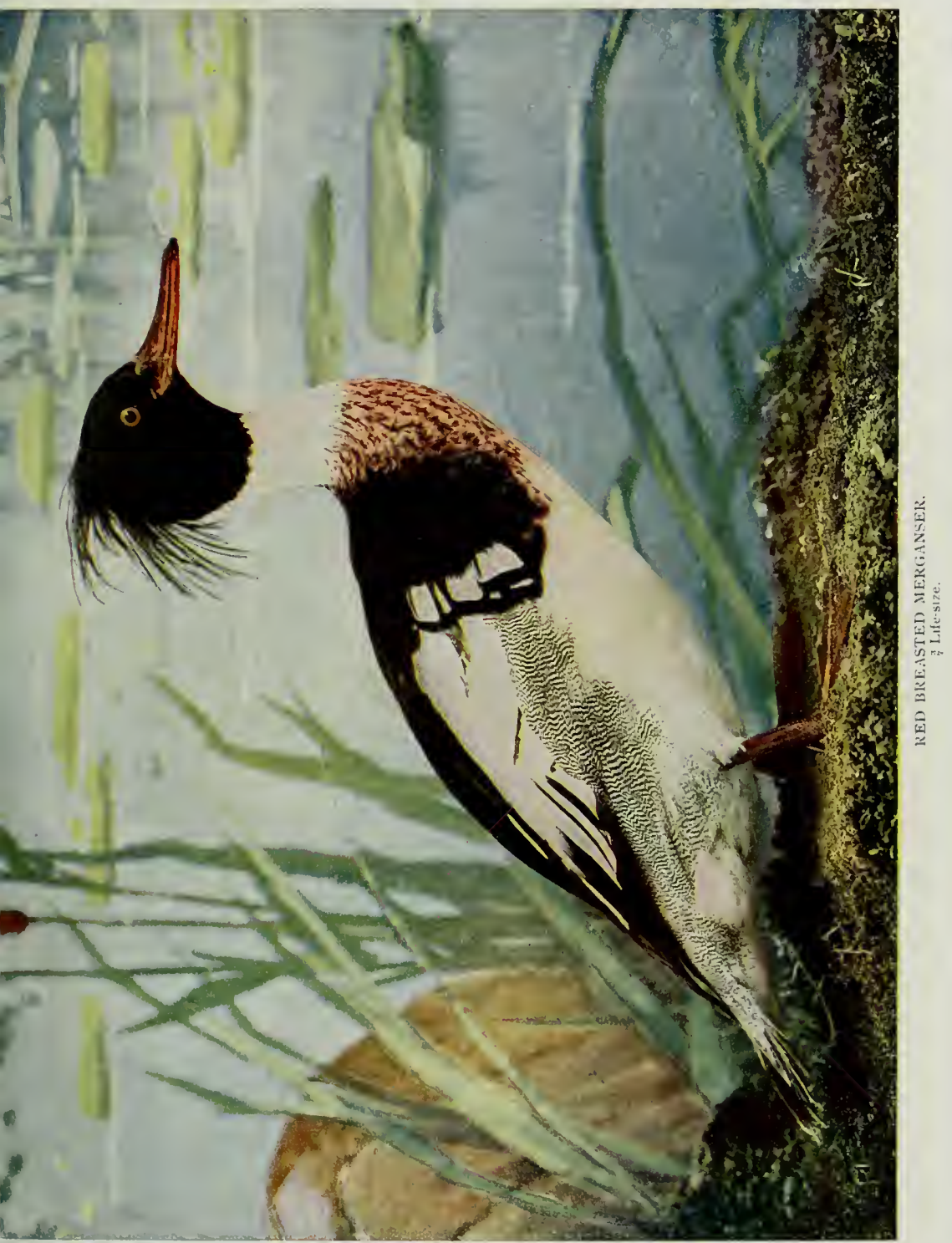





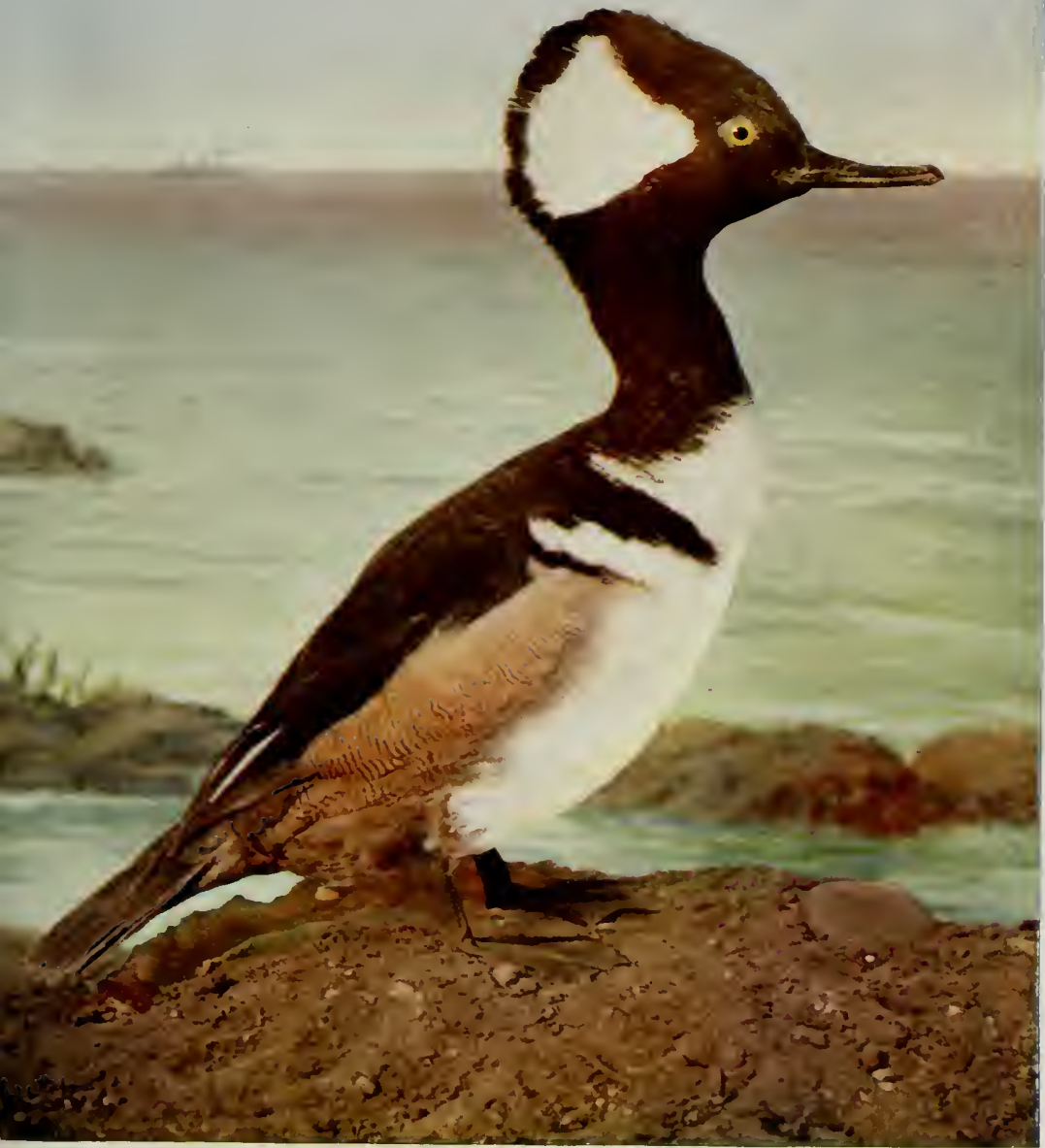



the handsomest of the tribe, the males rivaling the wood and harlequin ducks in beauty. So they are not only slaughtered by the sportsmen, but they are also sought by the taxidermist and plume hunter, consequently are becoming scarcer.

Among brushwood, boulders, and grass, near the water's edge, often on islands, the female merganser constructs a bulky nest of grass, leaves, and stems, lined with a moderate quantity of down and feathers; from six to twelve dark drab eggs are laid, having a greenish or reddish tinge. The beautiful male deserts his mate while she incubaies the eggs and cares for the young.

Mr. Chamberlain says: "I paddled after a brood one hot summer's day, and though several times they were almost within reach of my landing net, they eluded every effort to capture them. Throughout the chase the mother kept close to the young birds, and several times swam across the bow of my canoe in her efforts to draw my attention from the brood."

\section{HOODED MERGANSER}

The Hooded Merganser ranges and breeds throughout America generally, wintering in Cuba and Mexico. It breeds only sparingly throughout the United States and southern Canada. Unlike most of our ducks, it is not gregarious at any season of the year.

The hooded merganser is the smallest of the three fish ducks common to America. The males are handsome birds with a conspicuous black and white crest. Our first impres- 
sion of a male hooded merganser is that of an extremely large-headed bird, so close and thick is the hood of white distinctly bordered with black. The hood disappearing after nesting season, it is then often mistaken for the redbreasted merganser.

They feed by pursuing and capturing fish and other marine life beneath the water. They manifest a decided preference for fresh running water, and are regularly observed along the rivers of Wisconsin, Illinois, Indiana, and Michigan.

Like the other mergansers, the birds avoid the marshes during the breeding season, and select a hollow stub or log in which to deposit their eggs. Frequently this cavity is in a tree growing in or near a secluded spot along some woodland watercourse. Like the wood duck, the entrance to the nest appears too small to admit the bird's body. The writer has witnessed a female merganser fly directly into a cavity containing her nest and eggs, without alighting at the entrance.

The shell of the pure white eggs is extremely thick. The writer has thirteen taken in April in Montana. The bird had removed considerable down from her breast, and this was placed about the eggs, which enabled them to incubate during the absence of the parent.

\section{MALLARD}

The Mallard, or Greenhead, is a large, handsome duck, common during the migrations to all temperate North America, from the Atlantic to the Pacific; nesting usually 


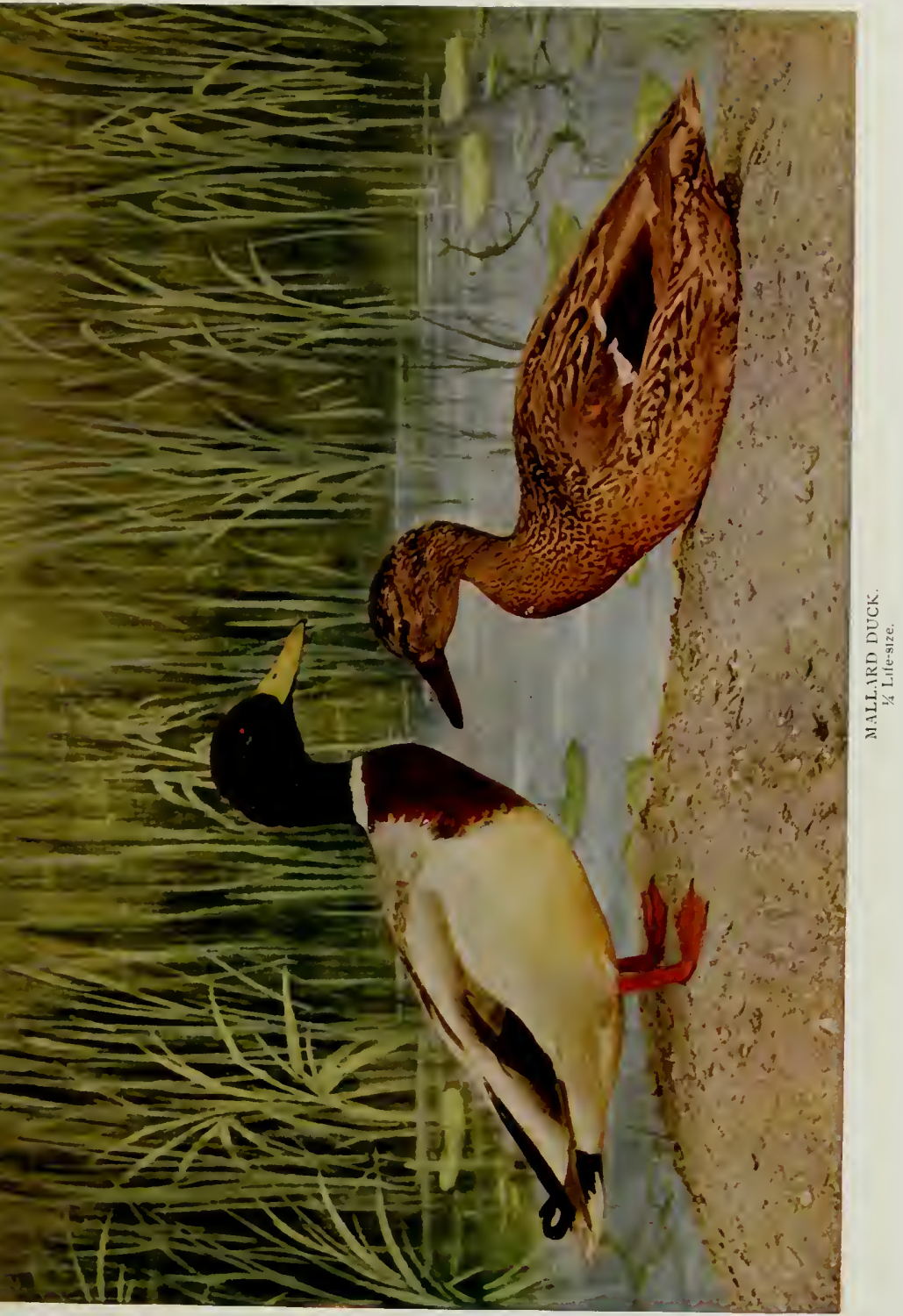





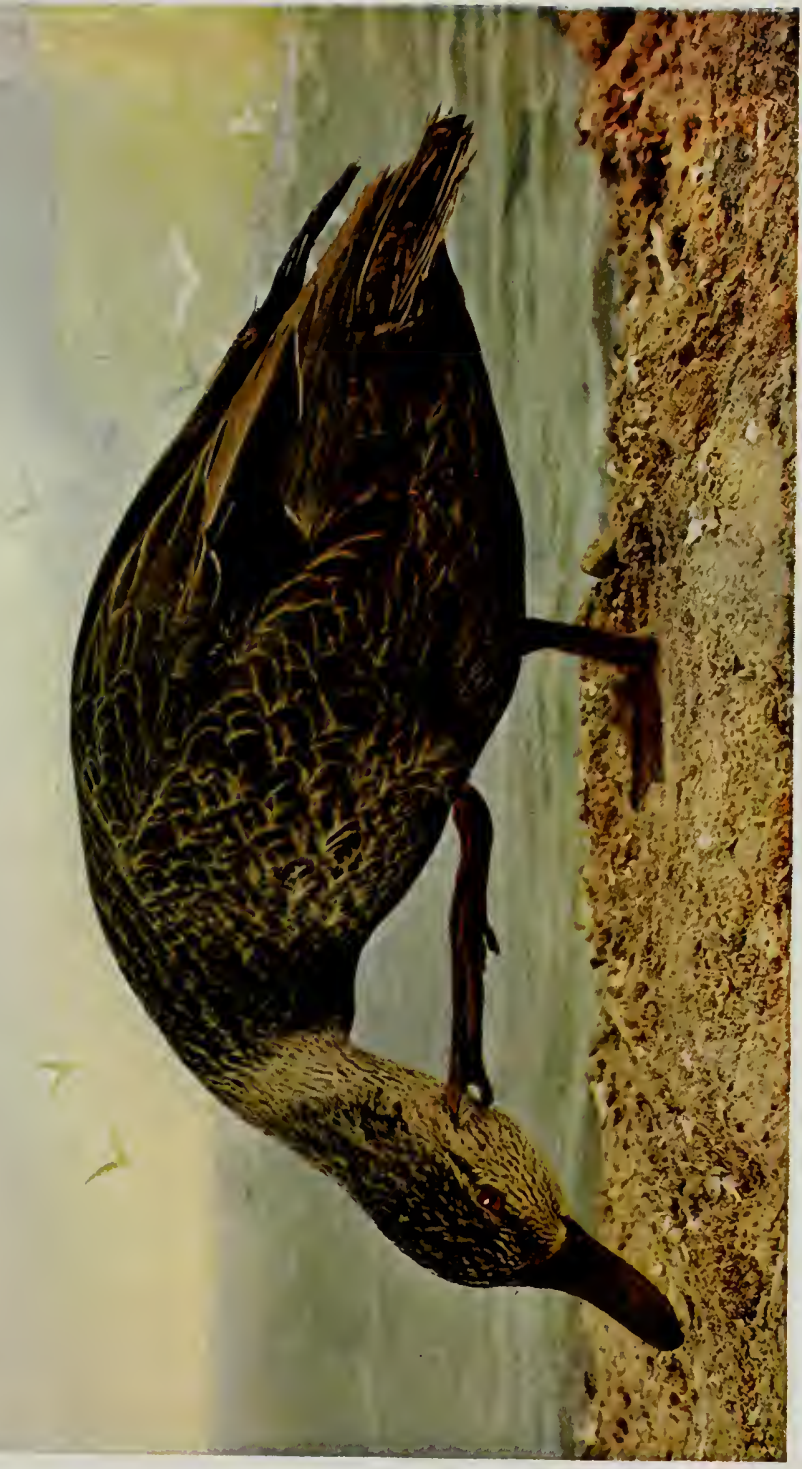



in the northern United States and northward, wintering in southern United States. A few remain and breed about isolated sloughs in the prairie sections of Illinois and Indiana. The female has the same quack as that of our domestic duck, which has descended from the mallard and readily crosses with it.

The mallard is distinctly a fresh-water duck, feeding usually by dabbling or dipping in shallow water. In the fall, great flocks of these birds descend upon the grain fields and gorge themselves. They are hardy birds, often remaining in the middle United States until late in November, returning during the first thaw in February. It is abundant, and a great favorite with the sportsmen.

Ten bluish-white eggs of this duck are in my collection, from Sweetwater Lake, North Dakota. They were taken June 11, 1900, from a nest of down and feathers, in a slight hollow of the earth, amidst a thick growth of underbrush extending out into the lake.

\section{BLACK DUCK}

The Black Duck, often called black mallard, black English duck, and dusky duck, is similar in habits and size to our common green-head mallard; the latter, however, has a much wider range. The black duck is rare west of the Mississippi, occurring usually in the East, from the Atlantic Coast through the New England States, Quebec, Ontario, and along the east coast shores of Lake Michigan.

They are among our slowest flying ducks, traveling about forty-five miles an hour, while teal and canvas-back 
ducks attain a speed of one hundred miles an hour. Unlike most ducks, the plumage of the sexes is similar.

The black duck often interbreeds with the common green-head mallard, but are less popular than the greenhead as a game bird. The female quacks, and the male utters a low nasal note. These birds usually inhabit shallow water, open marshes, little streams, and small freshwater lakes. The winter range extends along the coast of Florida, the Gulf States, and the waters of Mexico.

While breeding usually north of the United States, they are fairly common in the wet sections of Maine. Seven to twelve eggs are laid, varying in color from pure white to light green. The nests are placed in grassy spots close to the water, and lined with a liberal amount of dark down.

\section{THE GADWALL*}

The Gadwall, Gray Duck, or Creek Duck, has a very extensive range, including the temperate zones of both the eastern and western hemispheres. It inhabits the British Isles and breeds in Norfolk County, England. In Holland it is abundant, and in the fall is one of the most common ducks to be found in the market.

In North America the gadwall is confined chiefly to the interior, and Florida and Georgia are the only States on the Atlantic Coast in which it occurs in any numbers. Along the Pacific Coast they are common residents of California. Many of these ducks pass the winter about the Gulf of Mexico, in Central America, and in the West Indies. It is quite common throughout Illinois, is rarer 




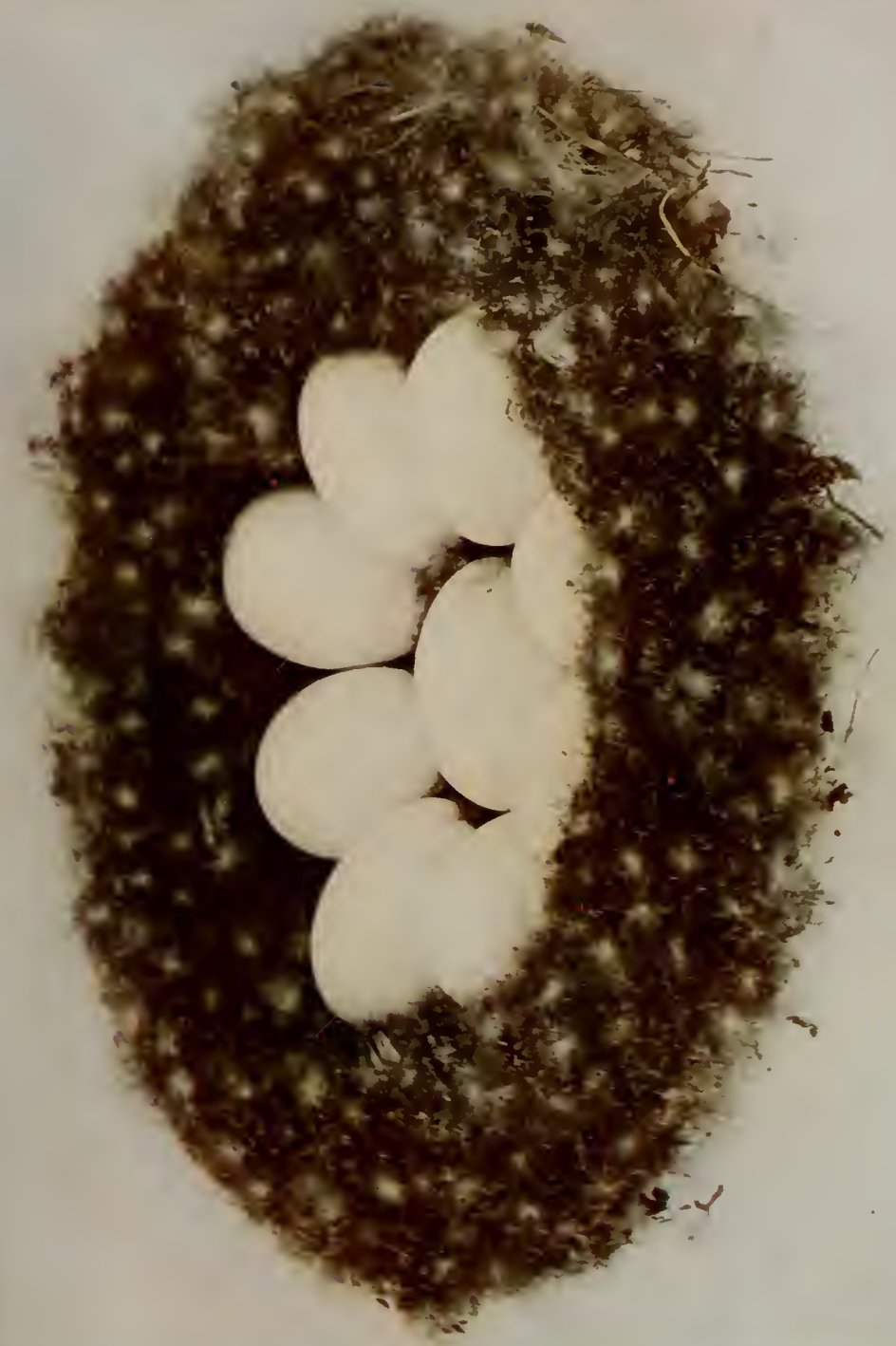





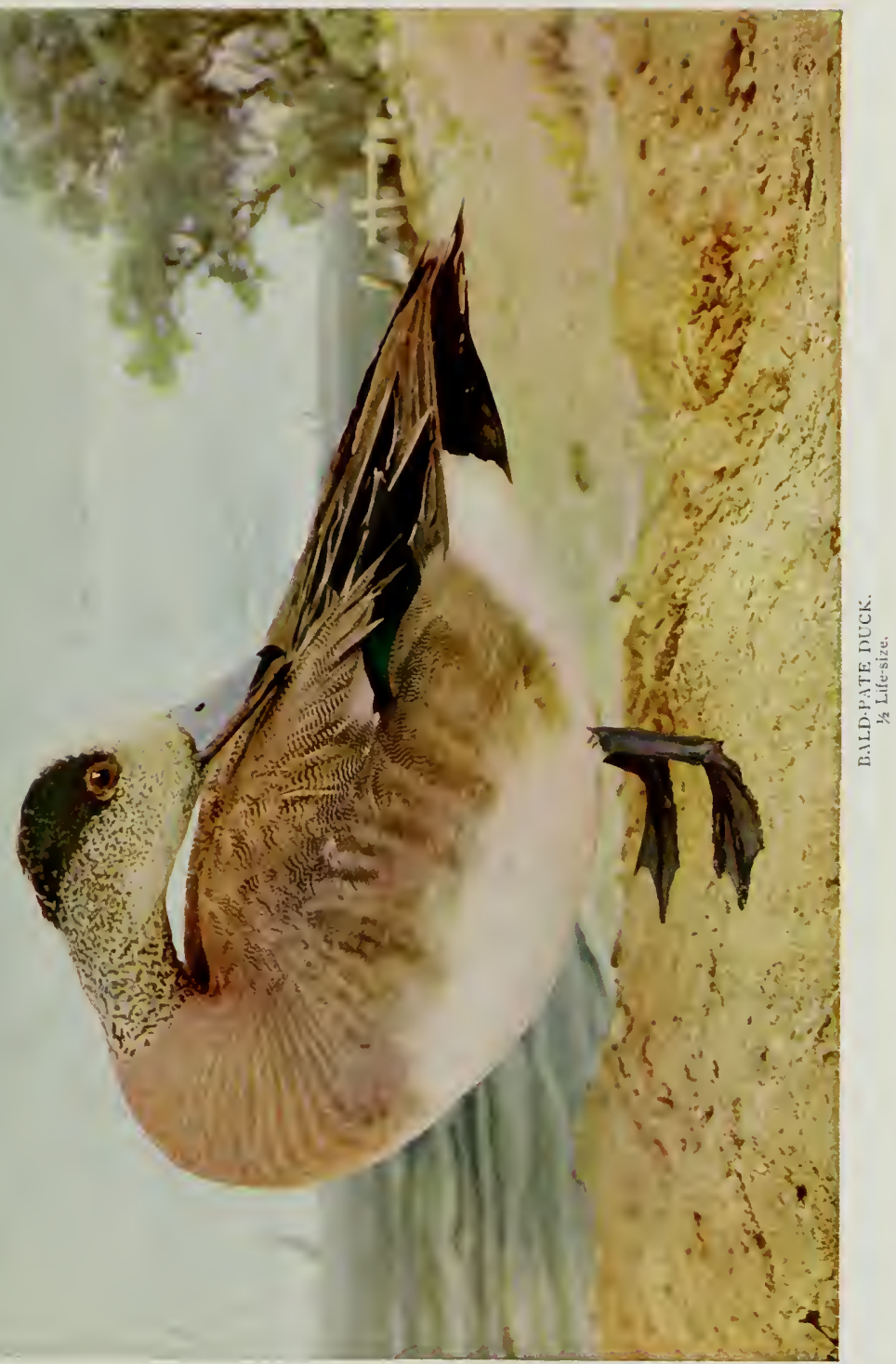



in Indiana, and in the upper and lower peninsulas of Michigan it is found in considerable numbers. It is likely to be found breeding anywhere within its range.

The general appearance and habits of the gadwall are quite similar to those of the mallard, teal, and widgeon. The latter name (widgeon) is indiscriminately applied to the three species: the gadwall, the baldpate, or American widgeon, and the European widgeon. All three varieties inhabit both the old and new worlds. The females and immature birds of the three species are often confused with each other. This is especially true of the baldpate and European widgeon.

The dress of the gadwall appears very sober when compared with our other ducks, the majority of which are noted for their beautiful plumage.

Its food consists of both animal and regetable matter, which is obtained from the surface of shallow lagoons and ponds. While feeding, the body is often partly submerged, as the birds probe about under the water. It seems to feed throughout the day.

Authorities differ regarding the note of the gadwall, but in my experience I have found them rather silent, occasionally uttering a few shrill "quacks" similar in tone to that of the mallard.

\section{BALDPATE}

The Baldpate ranges throughout North America, breeding in the interior, from Minnesota northward, wintering in Central America and northern South America.

The baldpate, or American widgeon, is a common spring 
and fall migrant in the Mississippi Valley. Though less popular and conspicuous than many other game birds, it is a delicately marked species.

The habits of these ducks are similar to those of the gadwall and teal; they enjoy mud flats and grassy ponds, feeding on vegetation, aquatic insects, and molluses. Especially fond of wild celery, but not good divers, they often procure it by snatching morsels from canvasbacks and other diving ducks, the instant their heads appear above the water.

On June 18, 1900, while searching in the buck-brush on the bank of Sweetwater Lake, North Dakota, the writer flushed a female baldpate from a nest of nine beautiful flesh-colored eggs, well hidden in a quantity of down and leaves.

\section{GREEN-IWINGED TEAL}

The Green-winged teal ranges throughout North America, breeding from Minnesota northward, wintering from Kansas and Virginia southward to the West Indies and Central America.

In size and general appearance, this duck closely resembles the blue-winged teal. The main difference is in color of speculum, or bright patch on wing; the habits, too, are similar.

The range of the green-winged is more northerly than that of the blue-winged, which frequently nests in the central parts of the United States. The green-winged is one of our handsomest fresh-water ducks. It is capable of flying with the wind at a speed of one hundred miles 

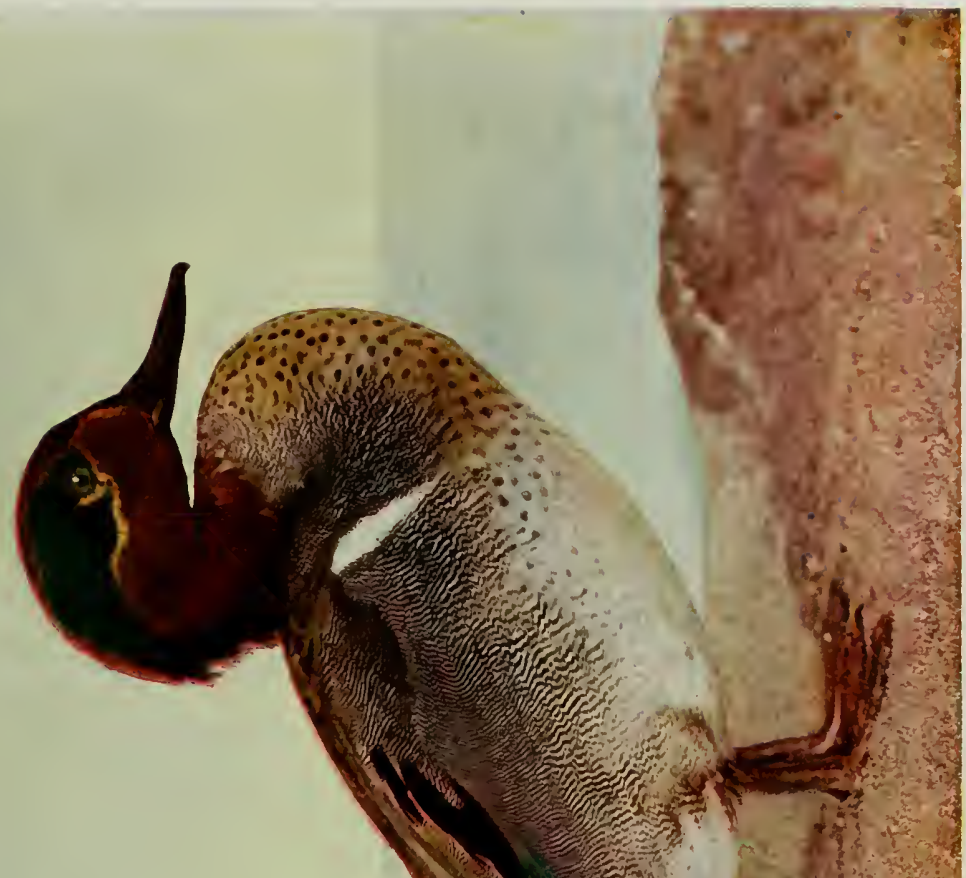

13

迹

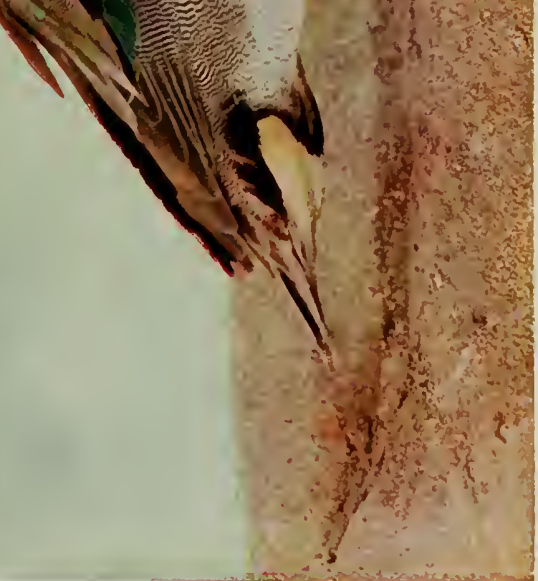




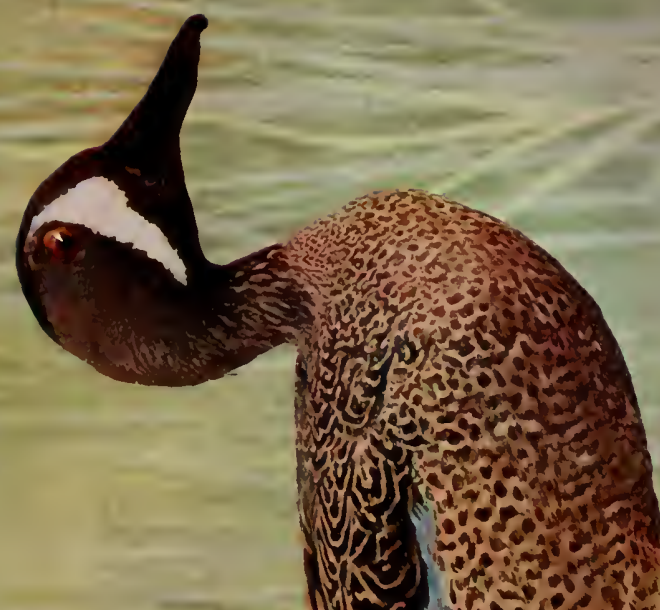

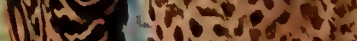

$40-5,1003$

,

$10+4 x^{2}-6$

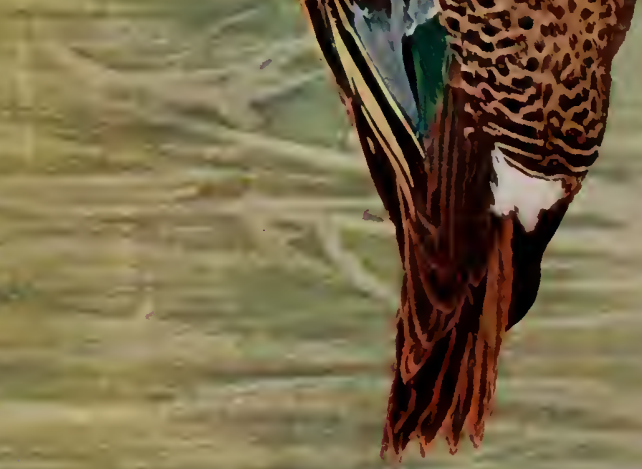

$\sum_{3}$

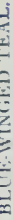

$x+1 ; i$

काष

hym. . त

$x+3$

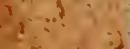

$3 i^{2}+y^{2} x ;$

istis is

$\because y^{4}: t_{2}$ ह

से 21

$x^{2}=18 ;$

$\therefore-2$

$15 \frac{j}{j}$

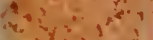

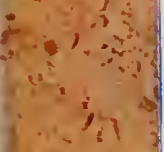

\&5 - 

an hour, the wings making a loud whistling noise. 'They feed in shallow water or wade about the shores of our inland ponds and lakes. Being practically surface feeders, and living often on wild grass seeds of the marshes, their flesh is second to that of no other duck in tenderness and flavor.

The green-winged remains in the Great Lakes region until the waters freeze, when our handsome blue-winged is many hundred miles farther south. It also reappears in the spring several weeks in advance of our other teals. 'The northern portions of central Canada are the favorite breeding grounds of this beautiful duck. Occasionally, however, it remains in the famous wild-fowl region about Devil's Lake, North Dakota.

The writer has ten pale ashy-green eggs taken in North Dakota from a nest which was in a tussock of coarse grass on dry ground, but close to the water's edge.

\section{THE BLUE-IVINGED TEAL*}

So many names have been applied to this duck that much confusion exists in the minds of many as to which to distinguish it by. A few of them are blue-winged; whiteface, or white-faced teal; summer teal, and cerceta comun (Mexico). It inhabits North America in general, but chiefly the eastern provinces; north to Alaska, south in winter throughout West Indies, Central America, and northern South America as far as Ecuador. It is accidental in Europe.

The Blue-winged Teal is stated to be probably the most numerous of our smaller ducks, and, though by far 
the larger number occur only during the migrations, individuals may be found at all times of the year uncler favorable circumstances of locality and weather. The bulk of the species, says Ridgway, winters in the Gulf States and southward, while the breeding range is difficult to make out, owing to the fact that it is not gregarious during the nesting season, but occurs scatteringly in isolated localities where it is most likely to escape observation.

The flight of this duck, according to "Water Birds of North America," is fully as swift as that of the passenger pigeon.

The nests are generally well lined with down, and when the female leaves the nest she always covers her eggs with down and draws the grass, of which the outside of the nest is composed, over the top. Professor Kumlein does not think that she ever lays more than twelve eggs. These are of a clear ivory white. They range from 1.89 to 1.95 inches in length and 1.25 to 1.35 in breadth.

The male whistles and the female "quacks."

The food of the blue-wing is chiefly vegetable matter, and its flesh is tender and excellent. It may be known by its small size, blue wings, and narrow bill.

The hind toe of this family of ducks is without a flap or lobe, and the front of the foot is furnished with transverse scales.

\section{CINNAMON TEAL.}

Cinnamon Teals range more southerly and westerly than our other teal. The flight of the cinnamon teal is probably more rapid than that of other waterfowl except 



$$
r
$$





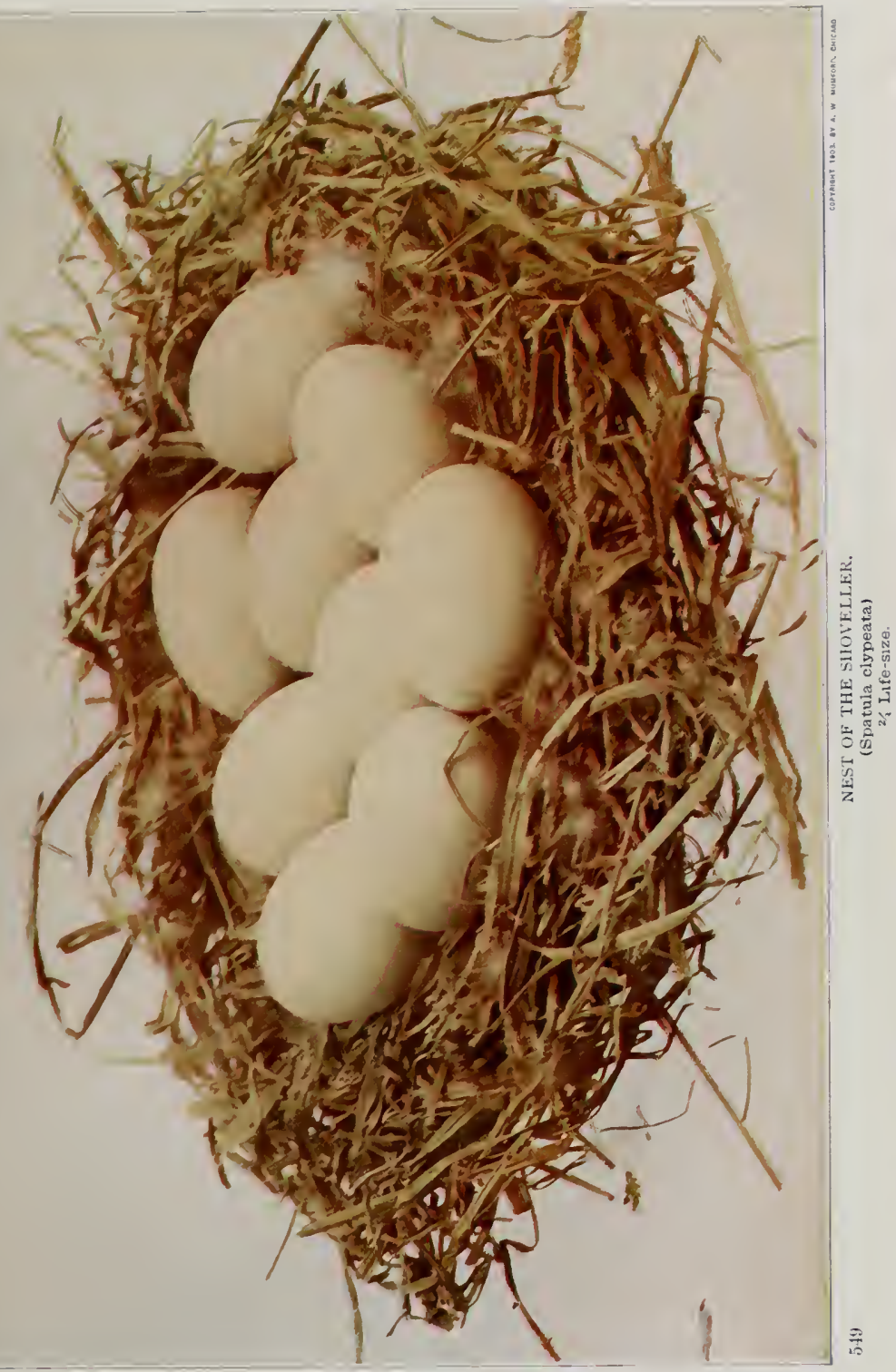



the canvas-back and blue and green-winged teal. These birds are prized by epicures, but fortunately they prefer mild climates, and many of them leave the haunts of the sportsman before the opening of the game season.

The males are beautiful birds, having plumage unlike that of any other waterfowl. Cinnamon teals are found on both fresh and salt water, but retreat to clear pools and streams to breed. They breed commonly in California and the Salt Lake region of Utah. The nests are placed on dry ground, usually in a thick clump of grass; six to twelve cream-colored eggs are laid from May 1st to June 10th.

\section{SHOVELER}

The Shoveler, or Spoonbill, is a bird of wide distribution, inhabiting all the continents and breeding in the northern portions of both hemispheres. It is a bird of striking individuality. The remarkable bill, the distinguishing feature, broadens at the end until it exceeds twice the width of the base, and assumes a spoon shape. Like other pond and river ducks, it is most abundant about fresh water.

It is a common summer resident of Minnesota and the Dakotas, thence it ranges northward through Manitoba, Assiniboia, and Alberta. During their semi-annual passage through Illinois, small flocks of shovelers are frequently seen on the Illinois and Kankakee rivers and on Lake Calumet. Usually they arrive from the south in March and by April the majority have paired, and soon move northward. In September and October its southern migration takes place to southern United States; it may occa- 
sionally be found in Cuba and South America in December and January.

Sportsmen do not look on this duck with the same pride that they feel for a "bag" of canvas-backs or teal; yet the flesh of the spoonbill is considered delicious.

The female's note bears a resemblance to that of the mallard, an oft-repeated "quack." It retires in May and June to the lakes and marshes, chiefly those of the interior, to breed.

\section{PINTAIL}

The Pintail ranges throughout North America, breeding from Iowa and Illinois to the Arctic Ocean; wintering from Virginia southward to the Greater Antilles and Central America.

'The gunner's sprig, or spike-tail, is not easily decoyed, being always suspicious of men. 'The pintails arrive in the Middle States with the first spring thaw, often late in February. 'They are strong fliers, frequently' covering eighty miles an lour. Frcsh-water ducks and feeding in shallow places by dipping or dabbling, their mode of feeding would make them highly palatable were they inclined to fatten, but one rarely finds a fat pintail. The female has a distinct low quack. They move about with some ease on land, appearing less awkward than most ducks.

The pintail resorts to the prairies of Minnesota, Dakota, and western Canada to breed. 'The nest is on a dry spot, sometimes a mile from water. The female scratches a hole in the earth and the eggs are deposited on a lining of dead grass, accompanied by a generous amount of down 


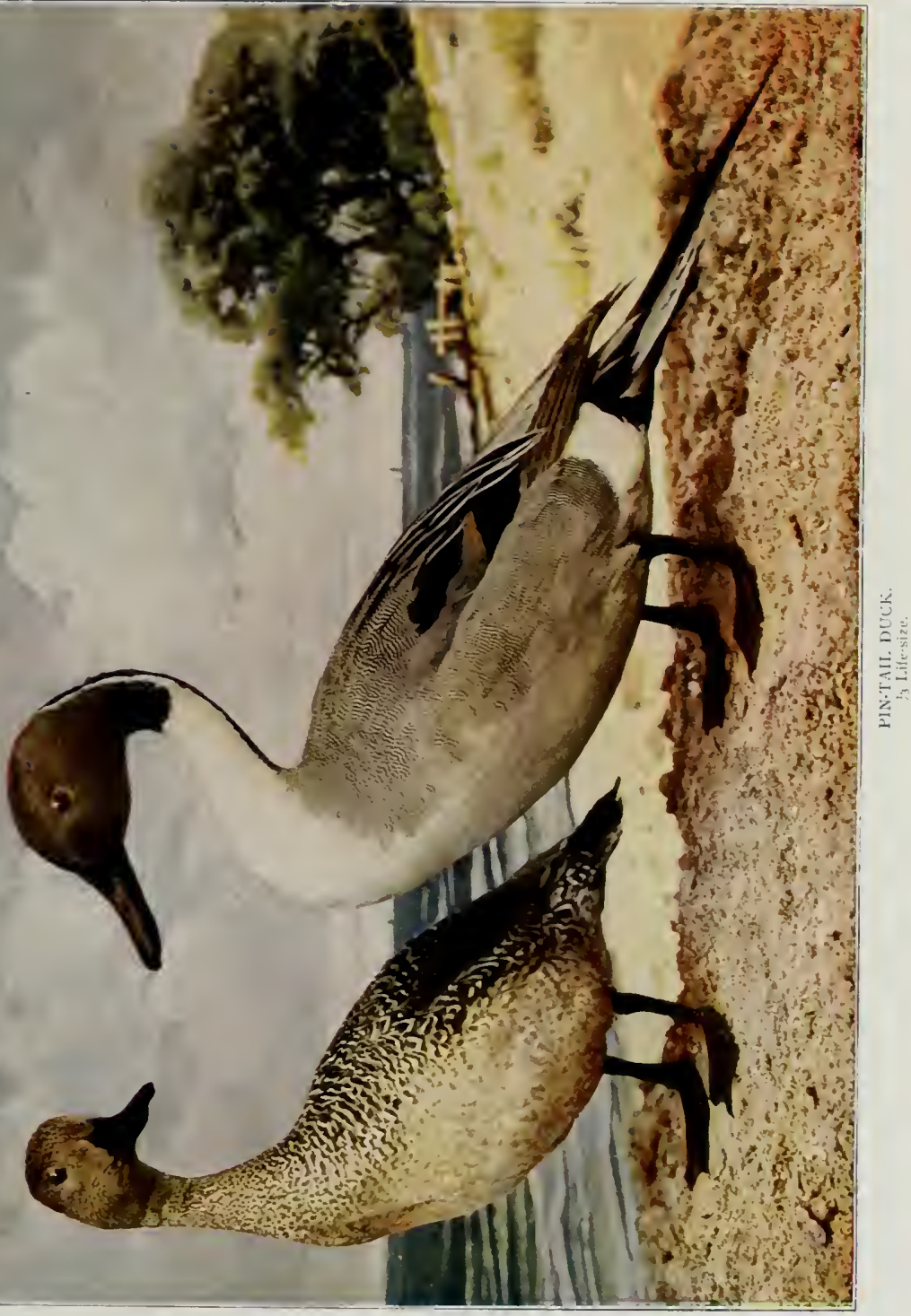





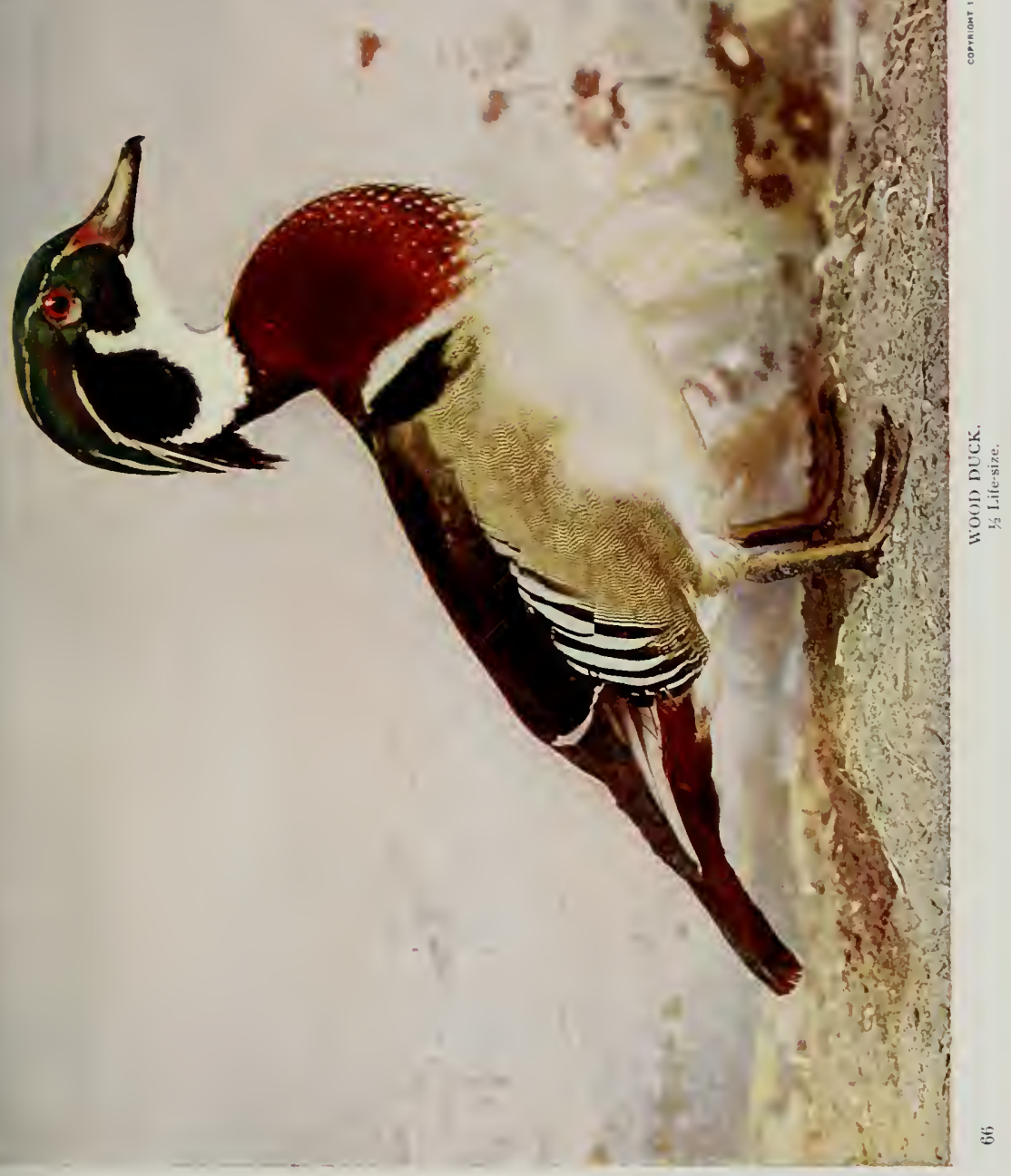



from the parent's breast. Eight to eleven pale ashy-green eggs are laid. The young are led to the water by the parent as soon as they emerge from the shell. Occasionally this bird nests on the lonely prairie of Iowa, Illinois, and Nebraska.

\section{WOOD DUCK}

The range of the Wood Ducks is quite extensive, covering temperate North America from Florida to Hudson Bay.

"Few, if any, more exquisitely beautiful creatures have been fashioned in the workmanship of Nature than the wood duck of America," are the words of Dr. Dawson, and to them we might add the words of Mr. Chapman: "Woodland ponds and rarious border streams make a proper setting for the grace and beauty of this richly attired bird." They do not quack, but have a pleasing and musical calla sort of whistle.

These birds perch upon branches of trees, and are fond of acorns. They are not solely dependent upon aquatic plants and animals or even upon food which is found upon the ground, but also eat flying insects and young buds.

It seems too bad that because of unscrupulous hunters this gem of the woodland should be in danger of extermination. Then, too, the open season for ducks does not offer protection, as the hunting season opens before the southern flight of most waterfowl which nest in the far North has begun. Therefore, our summer ducks are for a time the only available game.

They build their nests and seek their food in unfre- 
quented woods near the water. Favorite nesting places are hollow branches of trees, an ol 'woodpecker's hole, or hollow stump, preferring holes that overhang the water or are near it. They will, however, often accept sites away from the water, in which case the parent removes the young in her bill to the water as soon as they are hatched, but the young do not return to the nest. The writer has eight eggs taken at Long Lake, Minnesota, May 21, 1903. The hollow tree in which the eggs were laid was profusely lined with down and feathers.

\section{REDHEAD}

The Redhead looks like a canvas-back, and is often mistaken for it; the difference is shown principally in shape of bill and upper head.

The redhead, or porchard, is one of our gamiest ducks, occurring throughout temperate North America, chiefly from the Great Lakes region westward. These ducks arrive from the south early in March, on the way to Dakota and Manitoba, where they are comparatively abundant.

The redhead decoys easily, but frequently feeds in large expanses of open water where the hunter is afforded no opportunity to approach within gunshot. The writer quotes the following from his article on "The Nesting of the Redhead Duck":

"They are very aquatic in their nesting habits, more so than any others of their family, except the canvas-back or ruddy duck, in whose company they are often seen during the breeding season. I discovered fifteen nests during one 


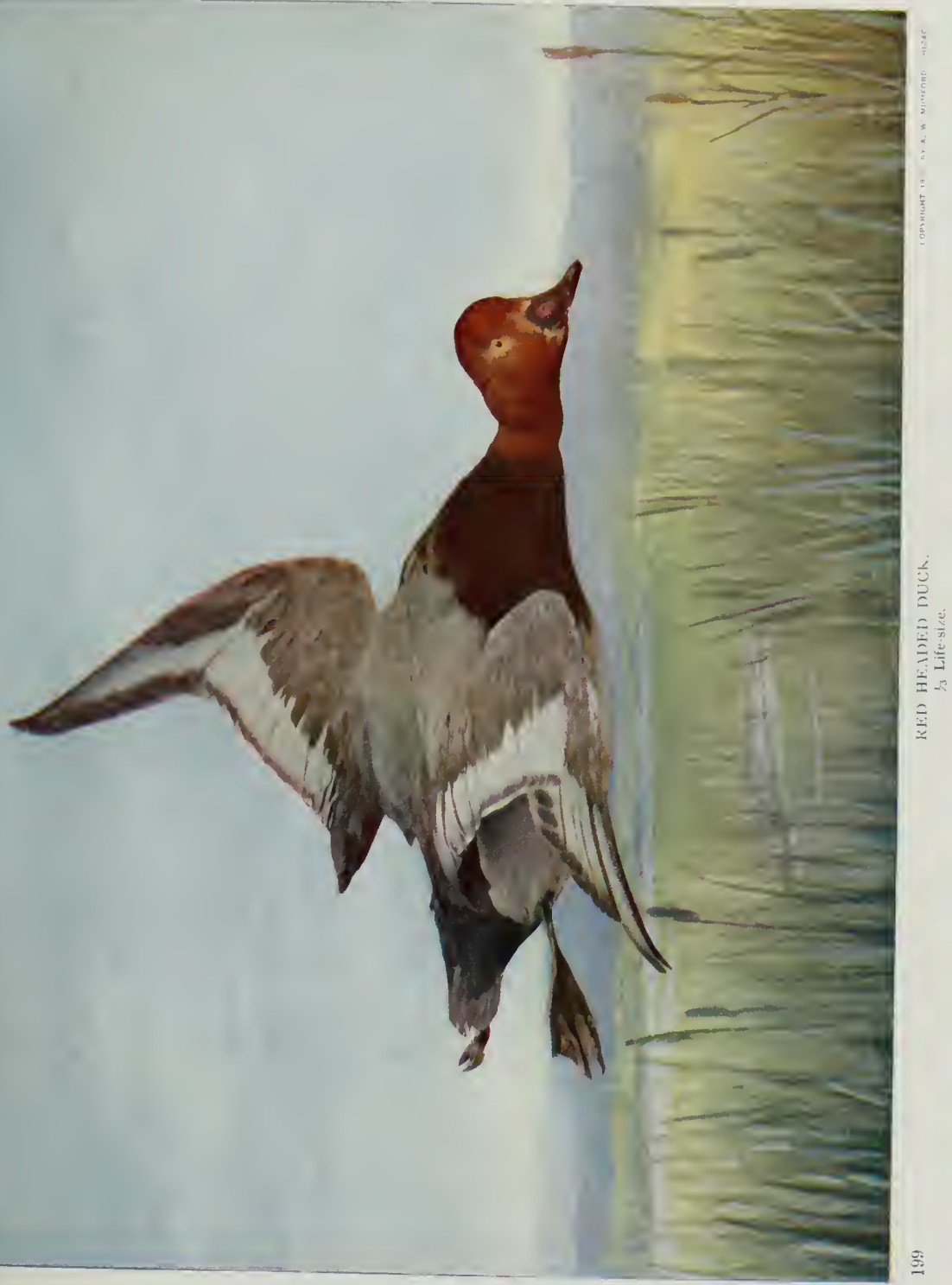





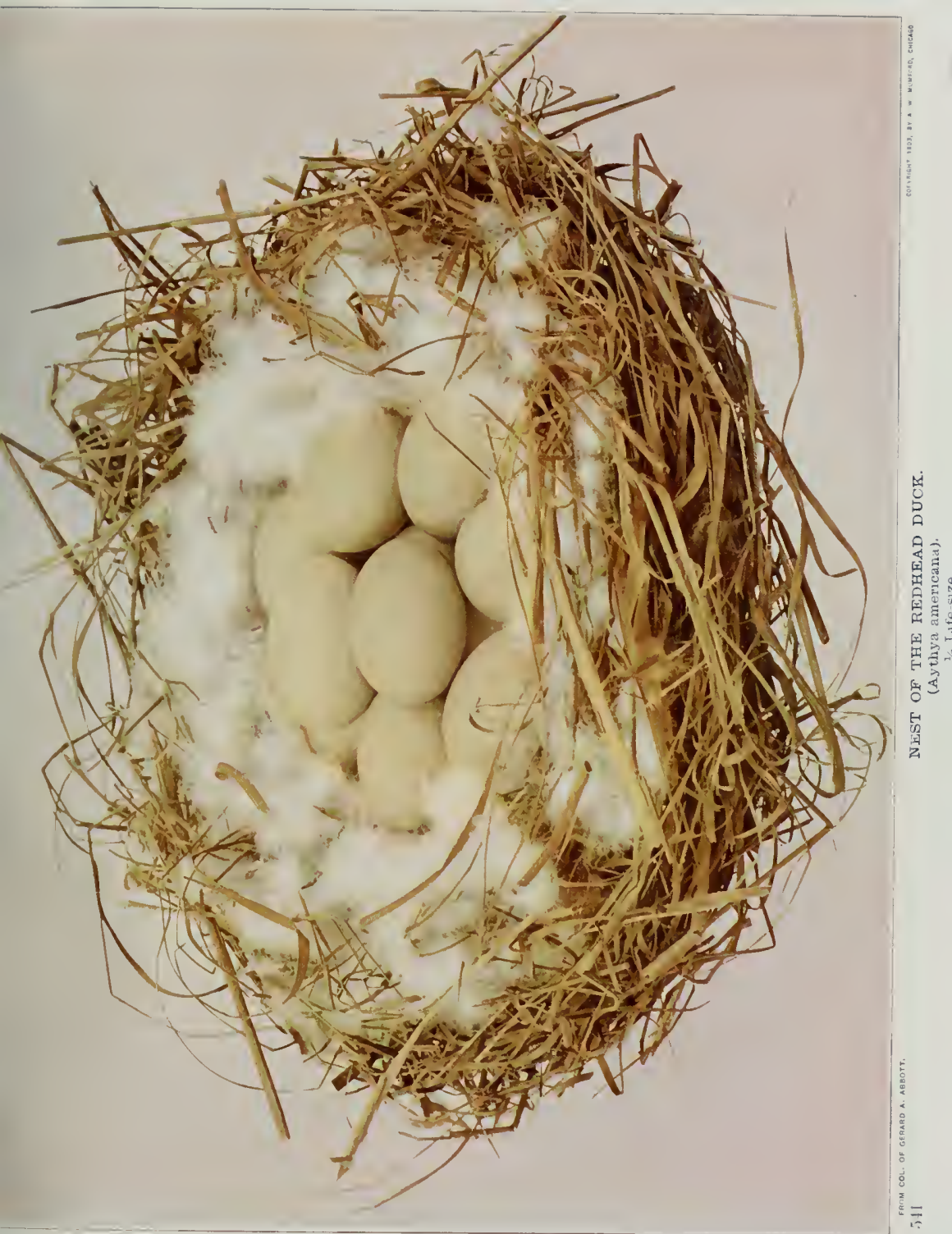




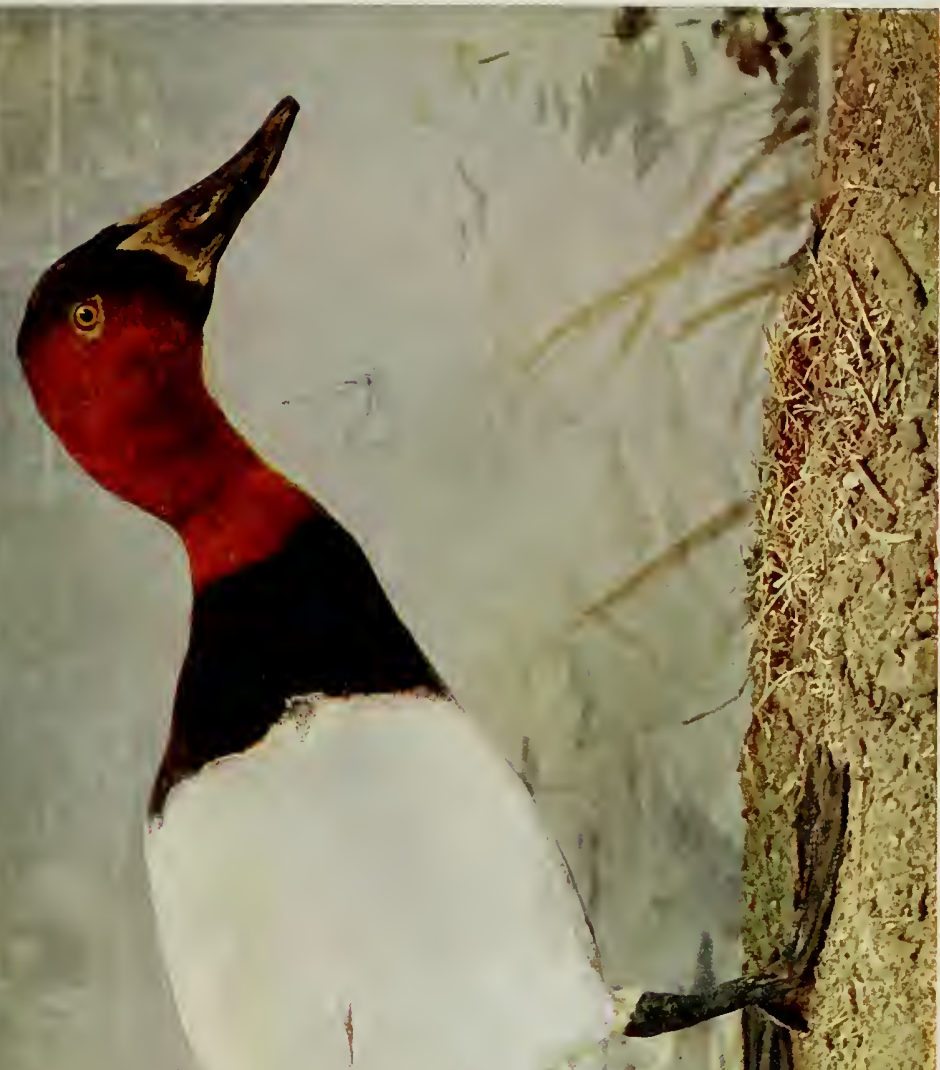

(1) 9 as 24 fibh arte as. $x_{1} x^{2}$

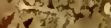
10,34 hisity

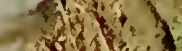
Netres $4=a+2$

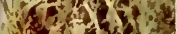

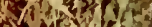

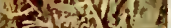
consts 1. 35,1 (2) $x+40$

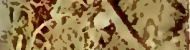
$150,15 \times 35$

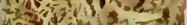
की स सर $32, a y=4,13$

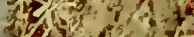
(n) $15,7=$

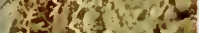

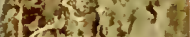
$M x^{2}(1),-1$ (4, $5,2 \times 1-1$ An

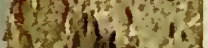

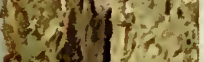

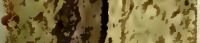

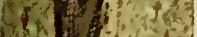

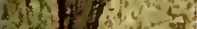

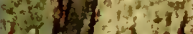
77 ins inf 造

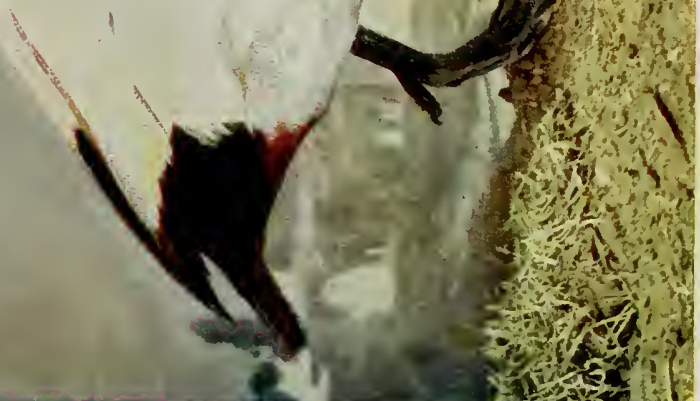

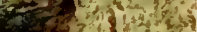
$+3, n y^{2}$

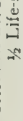



June in the Devil's Lake region in North Dakota. 'These nests were placed in tall grasses or reeds growing in water from one-half foot to three feet deep. In no instance were the eggs placed on the ground. The dry grass is massed together, forming a float, upon which the nest of practically the same material is placed. Frequently the birds construct a floating nest. It is a beautiful sight to observe the female as she leaves her nest, uttering a soft quack as she paddles out of sight among the tall grass."

Ten eggs taken June 3, 1900, were placed in a large nest containing one and one-half ounces of feathers and down, plucked from the breast of the parent bird. The down serves as a means of incubation during the duck's absence.

\section{CANVAS-BACK}

Few game birds are more celebrated than the Canvasback; sportsmen and epicures find that it meets their ideal of game qualities. It flies rapidly and with directness, dives quickly, swims rapidly, and is remarkably wary and alert, while its flesh is considered incomparably delicious by many, especially if the bird has been feeding on the "watercelery," an abundant fresh-water plant, and its favorite food.

The canvas-back is peculiar to North America. Its nearest foreign relative is the red-crested porchard of Europe and Asia. The abundance of this noted game bird in the temperate regions is governed chiefly by the amount of water and the amount of "water-celery" found in any locality. It frequents both the Atlantic and Pacific coasts 
during migration, but confines itself to the interior while breeding. It is rarely found in northern Illinois and Indiana, although a number of them have been taken at English Lake, Indiana; Fox Lake, Illinois, and also at Lake Koshkonong, Wisconsin. A few males were also observed by the writer at Chillicothe, on the Illinois River. Its favorite food grows in all these waters.

The canvas-back is fairly common throughout the Devil's Lake region of North Dakota, where it nests with the redhead among the grassy sloughs and pot-holes, or on the borders of marshy lakesides.

One of the first duck's nests the writer ever found was that of a canvas-back, while searching for American bittern's eggs, in the latter part of May, 1900, near Sweetwater Lake, North Dakota.

The nest, about the size of a bushel basket, but with a much smaller capacity, was securely anchored to several large clumps of marsh grass, over water several feet deep. It was a bulky affair, consisting of dry grass and hay, sparsely lined with down and feathers. An incomplete set of four fresh eggs in the nest were partly concealed by the wary female, which had attempted to cover them with down.

In Northwest Canada, the canvas-back nests abundantly in June, when it deposits from seven to twelve deep ashygreen elliptical eggs. Incubated eggs of this species, like the eggs of other Northern ducks, are usually surrounded by a quantity of down, plucked from the female's breast. The down of the canvas-back is much darker than that of the redhead, the latter having a grayish-white down, and the canvas-back's being slaty-gray or mouse-color. 


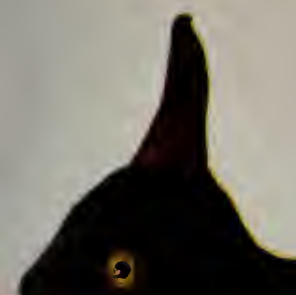





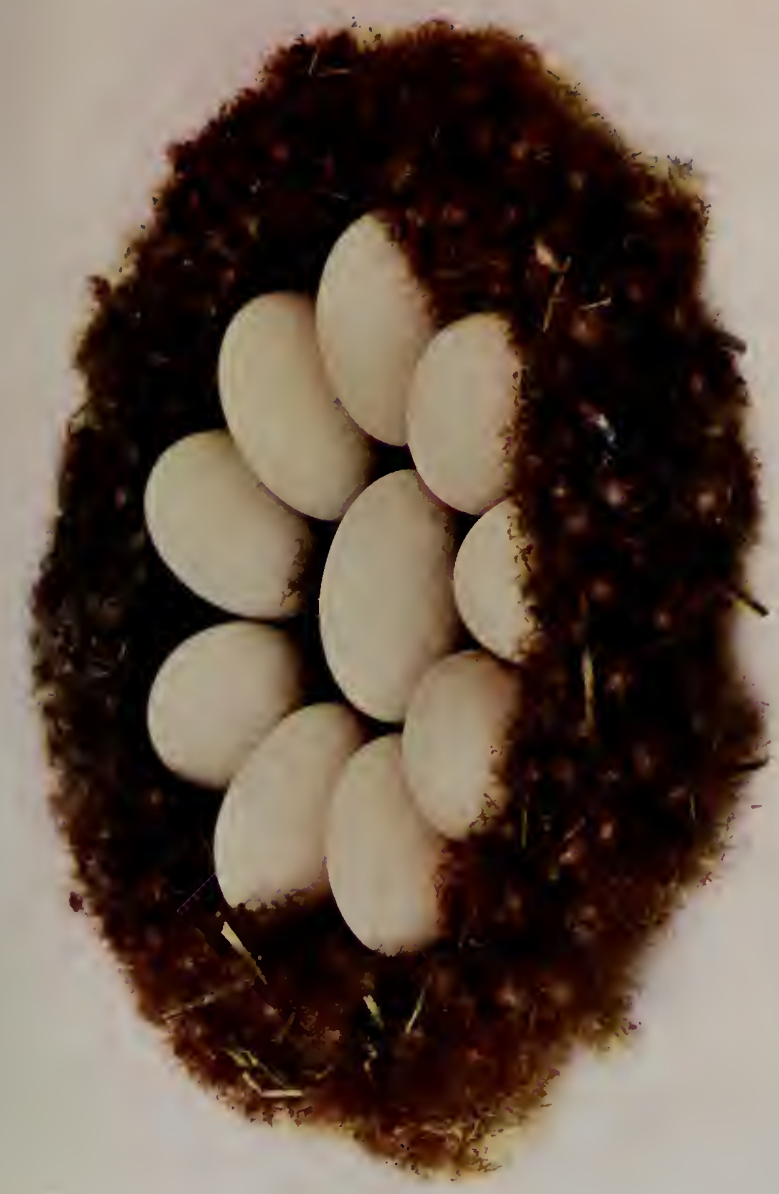

5 

A single nest is frequently found containing eggs of both canvas-back and redhead, but usually only one duck sits on the eggs.

\section{LESSER SCAUP DUCK}

The Lesser Scaup, Little Black-head, Little Blue-bill, Creek Broad-bill, Raft-duck, and Flocking-fowl, are some of the numerous names applied to this species. Three varieties of scaup ducks inhabit North America-the greater scaup, the lesser scaup, and the ring-necked scaup. When migrating, the lesser scaup frequents both fresh and salt water, but during the breeding season it is usually seen in the interior.

In general appearance and habits, this duck resembles the great scaup, but averages one and one-half inches shorter. In many localities it is the most abundant duck; this is true of the Calumet region of northern Illinois and Indiana. The little scaup furnishes royal sport to the gunners, especially during October and April, being easily decoyed.

Many lesser scaups, especially the males, linger on Lake Michigan six months in the year; in fact, this bird has been recorded monthly from January to December.

The scaups are expert divers, often descending forty feet below the surface for their food. When pursued, wounded birds have been known to dive among aquatic plants and close their bills on some reed, remaining there until dead.

Like the chimney swift, a trio of birds are commonly observed flying together, usually a drake and two females. Like certain other ducks, the lesser scaups do not breed 
until they are two years old. This accounts for the appearance of lesser scaups upon southern Lake Michigan throughout the summer.

In Devil's Lake region of North Dakota the lesser scaup breeds, being a common summer resident save while nesting, it inhabits deeper water than other ducks, except the canvas-back and redhead. After June 1st a drake may be seen in company with several females paddling about in the grassy sloughs near nesting grounds. Scaups are partial to small islands which afford sufficient concealment for the nest. Six to eleven light olive-green eggs are laid.

\section{THE RING-BILLED OR RING-NECKED DUCK*}

This duck has many popular synonyms, among others Ring-billed, Ring-billed Shuffler, Ring-necked Scaup Duck, or Blue-bill Fall Duck (Minnesota), Black Jack (Illinois), Moon-bill (South Carolina). It is found throughout the whole of North America, south to Guatemala and the West Indies; breeding from Iowa, southern Wisconsin, Minnesota, and Maine northward. It is accidental in Europe.

The chief variation in the plumage of this species consists in the distinctness of the chestnut collar in the male, which is usually well defined, particularly in front. There is very little in its habits to distinguish it from the other "black-heads." Like them, it usually associates in small flocks. Its flesl is excellent, being fat, tender, and juicy. W. L. Dawson, in "Birds of Ohio," says: "This elegant species bears a general resemblance to the lesser scaup, but is nowhere so common unless it be in Minnesota, the 



center of its breeding range. Unlike the scaup, it is never seen in large flocks, seldom in companies of above a dozen or twenty individuals; it shuns the open water, so much frequented by the blue-bills. In flight the individuals of a flock scatter widely, and they are likely to become still further separated as they feed in the rushes and deeper growth of the swamp. Here they subsist upon crayfish, snails, frogs, insects, and the various sorts of seeds which drop into the water from overhanging vegetation.

"When surprised, the ring-neck rises upon softly whistling wings, and beats a rapid retreat, while you notice the loose occipital feathers, ruffled by fear into a bushy crest, and observe that there is no white on the head to cause confusion with other crested spccies."

\section{GOLDEN-EYE}

The Golden-eye, or "Whistler," and decidedly a deepwater fowl, is a common winter resident on the Great Lakes and in the larger rivers. It occurs from coast to coast, but the Barrow's golden-eye chiefly replaces this form from the Rocky Mountains westward. A flock of golden-eye traveling with the wind at eighty miles an hour produces a sound with their wings from which the bird derives the name whistler. Feeding almost entirely on fish, they are not so good eating as are most ducks. These birds are expert divers, and sometimes are caught in nets which have been lowered into five fathoms of water.

During the spring, the golden-eyes retreat to the timbered lakes, near which each female selects a hollow trec, 
where eight to fourteen beautiful bluish-green eggs are deposited. The writer found ten eggs, fourteen feet from the ground, in the hollow of an oak on a timbered peninsula jutting out into Devil's Lake, North Dakota. In passing he noticed little particles of down attached to the bark above the cavity. Inspection disclosed the incubating bird, which refused to leave her treasures until touched.

\section{BUFFLE-HEAD}

This beautiful little duck, known as Buffle-head, Butterball, or Spirit Duck, ranges from the Atlantic to the Pacific, migrating in October to the Gulf States and Mex-, ico. A few remain in the northern portions of the nerthern tier of States, but the wild lakes of Ontario, Manitoba, and Alberta are the regions frequented during the nesting season.

It is the smallest of our deep-water ducks, not abundant, and seldom seen in large flocks. The large head of the males is covered with a crest of greenish-blue and white feathers, which they raise and lower, thus presenting a picturesque sight as they swim about on the water, diving with remarkable rapidity. Their flight is strong and rapid, making them a good mark for the sportsman.

Their food is principally fish and other small marine life, which they secure by descending into great depths of water.

Like the golden-eye, the wood duck, and the mergansers, the buffle-head deposits her eggs in hollow trees. It is remarkable how small an entrance will accommodate the 


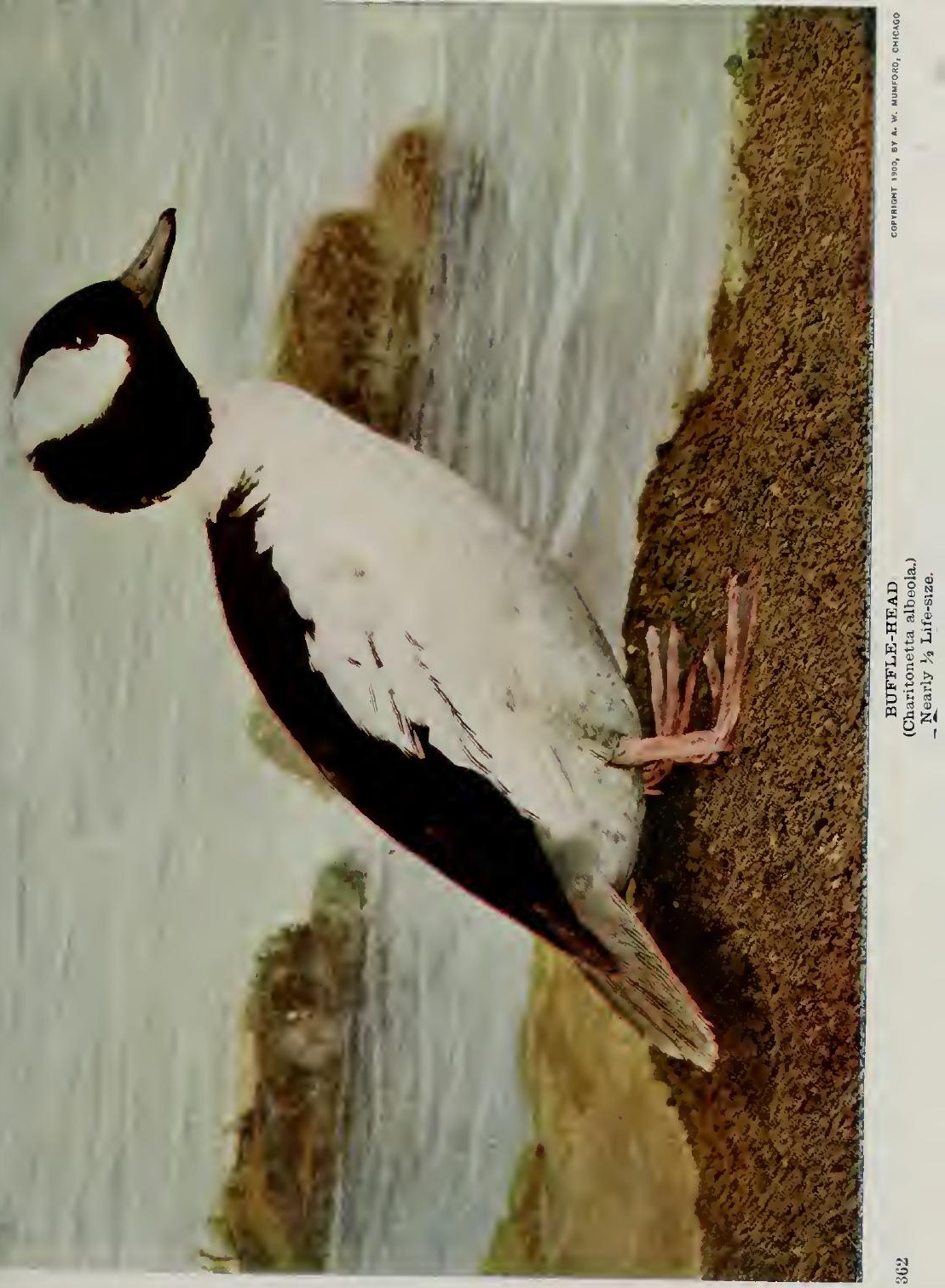





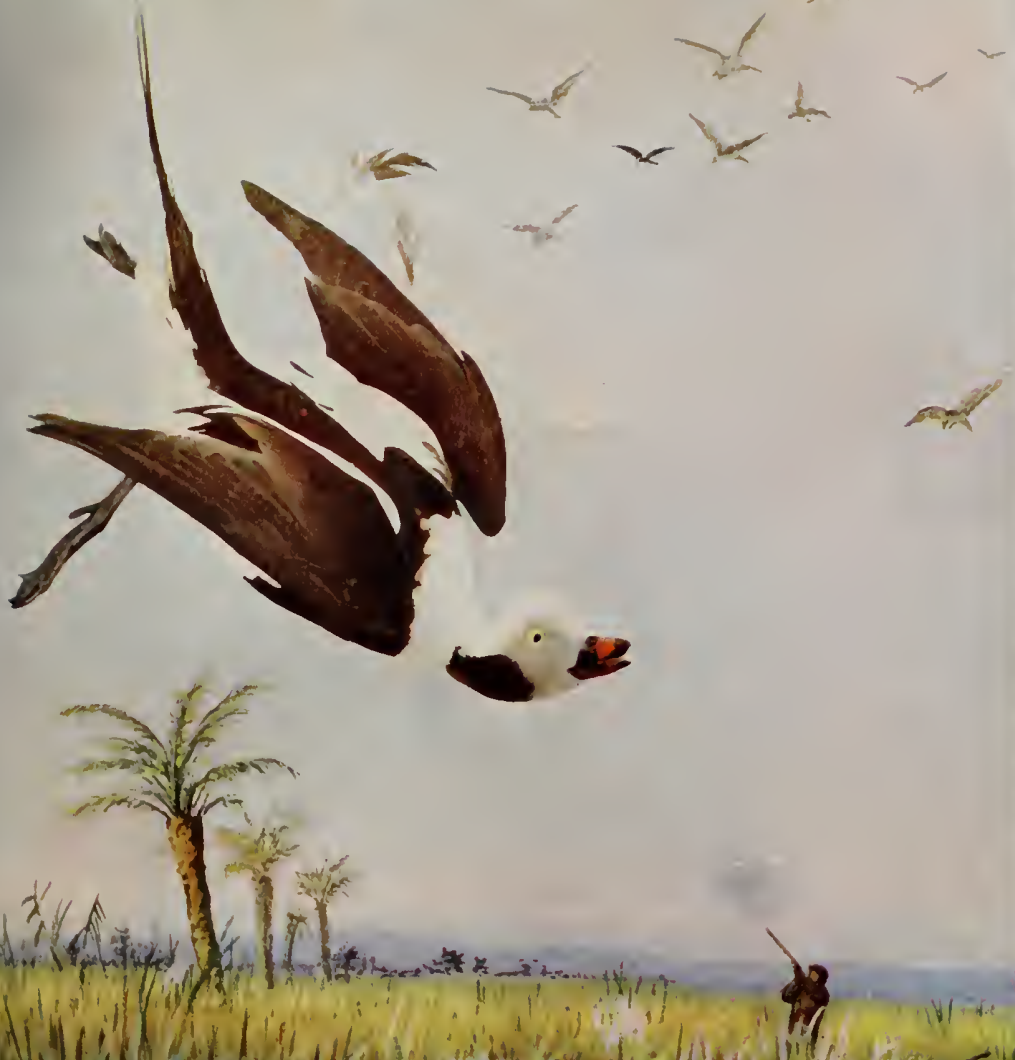

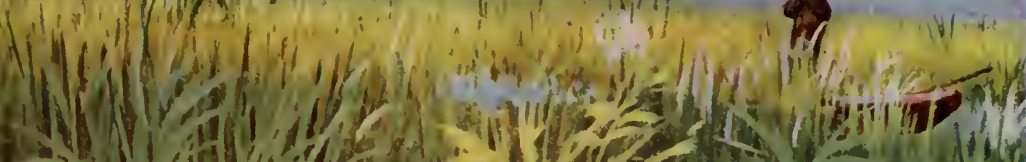

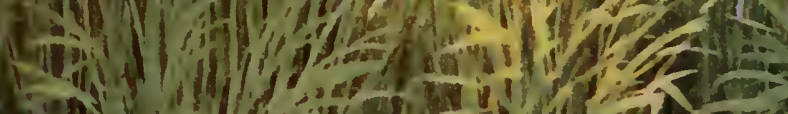

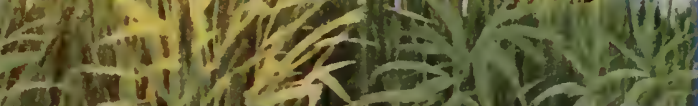

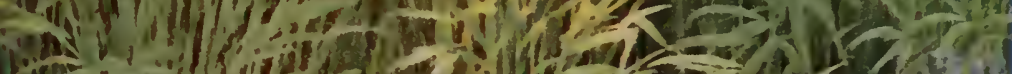

(ivine

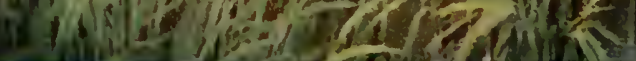



female, which frequently uses the abandoned nest of a flicker. Light-colored down is used to cover the six to nine ashy-gray eggs, which continue to incubate while the parent is away.

\section{THE OLD SQUAW DUCK*}

Here is an instance where the female is the head of the family indeed, for by common consent the name includes the male of this species. It has numerous other names, however, as Old Wife, South-southerly, Long-tailed Duck, Swallow-tailed Duck, Old Injun (Massachusetts and Connecticut), Old Molly, Old Billy, Scolder (New Hampshire and Massachusetts).

The liabitat of the Old Squaw is the northern hemisphere; in America, south in winter to nearly the southern border of the United States. It is distributed througlout the northern portions of the globe, but makes its summer home in Arctic regions. George Harlow Clarke, naturalist, Peary polar expedition, in a recent article, mentioned that, "In June the old squaw's clanging call resounded everywhere along shore, and the birds themselves were often perceived gliding to and fro amid the ice cakes drifting with the tide between the main ice-floe and the land." It is a resident in Greenland, and breeds in various places in Iceland. The nests are made on the margins of lakes or ponds, among low bushes or tall grass, are constructed of grasses, and generally, but not always, warmly lined with down and feathers. The eggs are from six to twelve in number. In the United States the long-tail is found only in winter. Mr. Nelson found it to be an abundant winter resident on Lake Michi- 
gan, where the first stragglers arrived about the last of October, the main body arriving about a month later and departing about the first of April, a few lingering until about the last of the month.

\section{THE HARLEQUIN DUCK*}

Harlequin is not the only name by which this bird is known. In the New England States and northward along the Atlantic coast it is frequently called the "Lord and Lady," because of the white crescents and spots of its plumage and the proud bearing of the male. It is also called the Rock Duck, the Mountain Duck, and the Squealer. Its range covers the northern portion of North America, Europe, and Asia. It breeds only in the northern part of its range.

The sexes vary greatly. While the male, which is the sex of the bird of our illustration, is brightly colored, the female is much more somber. 'The young resemble the adult female.

The food of the harlequin consists almost entirely of parts of aquatic plants and the smaller crustaceans and mollusks.

Its nest, though usually placed on the ground, is sometimes built in the hollow of a tree or hollow stump, though always near a body of water. The nest is usually a simple structure made of the stems of water plants, twigs, and grass, thickly lined with the downy feathers from the breast of the duck. 'The eggs are occasionally laid on the grass, and no effort is made to build a nest. 'The female thoroughly covers the eggs when she leaves the nest. 


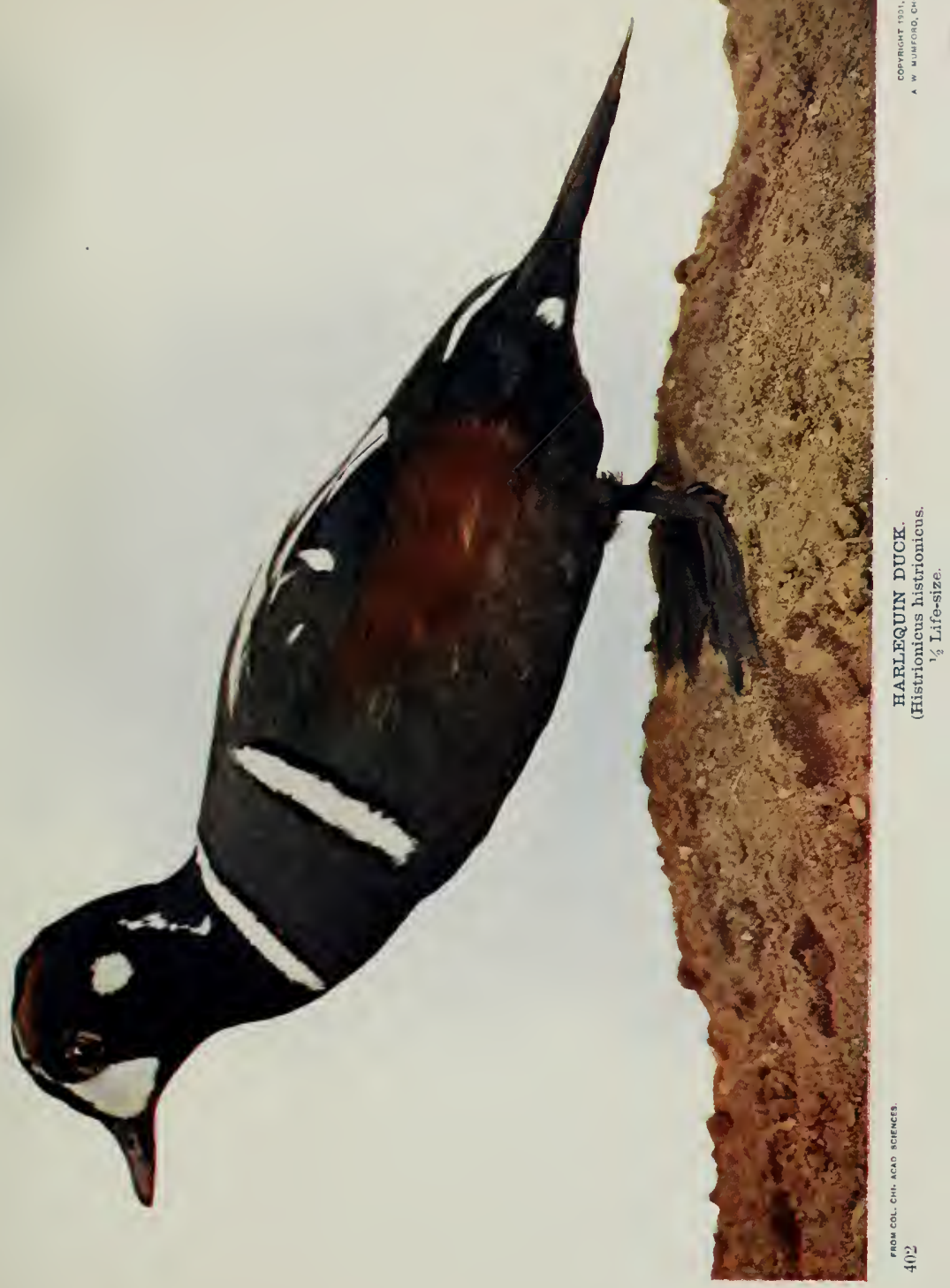




The number of eggs varies from six to eight, though ten have been recorded. They are of a "yellowish-buff or" greenish-yellow" color.

\section{WHITE-IVINGED SCOTER}

The Scoters are partial to the sea coast. Among the hunters they are known as "sea coots." Three scoters are common to the American continent; the other two are the Surf Scoters, commonly called the Surf Duck, or Patchhead Coot, and the American Scoter, known as the Butterbilled Coot. The White-winged Scoter inhabits both the Atlantic and Pacific coasts, and is found on the Great Lakes during the winter months.

The flight is slow and peculiar. The males are striking in appearance, with their glossy black feathers broken only by white patches on the wing and a small white patch above the eye; the iris is white, the bill yellow and red.

Large flocks of these birds congregate annually during the summer months among the outer islands of Casco Bay, Maine, but they have nerer been found breeding in this territory. This is one of the strongest evidences to many that the white-winged scoter's nesting habits are unknown, because they disappear from regions where they are common except during June and July.

During these months they breed on large inland lakes in Canada and northern United States, especially in the Devil's Lake region of North Dakota, as they seem to enjoy its alkaline waters. A peculiar characteristic is the southward flight made by these birds when they appear at 
Devil's Lake in June to breed, as they arrive direct from the North to rear their young in the treeless tracts of the Dakotas.

The nests are usually slight hollows in the earth under a tussock of grass or a small bush on dry ground where the lake forms a hard shore.

\section{THE SURF SCOTER*}

The Surf Scoter is also known by several other popular names, such as the Surf Duck, the Surf or Sea Coot, and, not infrequently, the Booby. The name Velvet Duck, though more commonly applied to the white-winged scoter, is also sometimes used to designate this species.

This scoter is an American species, and is only an accidental visitor to European coasts. Its range includes the "coasts and larger inland waters of northern North America; in winter, south to Florida, to the Ohio River, and to San Quentin Bay, Lower California."

Our illustration is that of a male bird. The female is a sooty brown, silvery-gray below, and with much white on the sides of the head.

The note of the surf scoter is to me the most pleasing of all the ducks. It is a soft, mellow whistle, ending in a "cluck! cluck!"

Mr. Nelson states that the surf scoter appears in the vicinity of St. Michaels, Alaska, about the niddle of May, and nests commonly in the marshes of the delta of the Yukon River. It also nests in large numbers on the Atlantic Coast, from Labrador northward. 


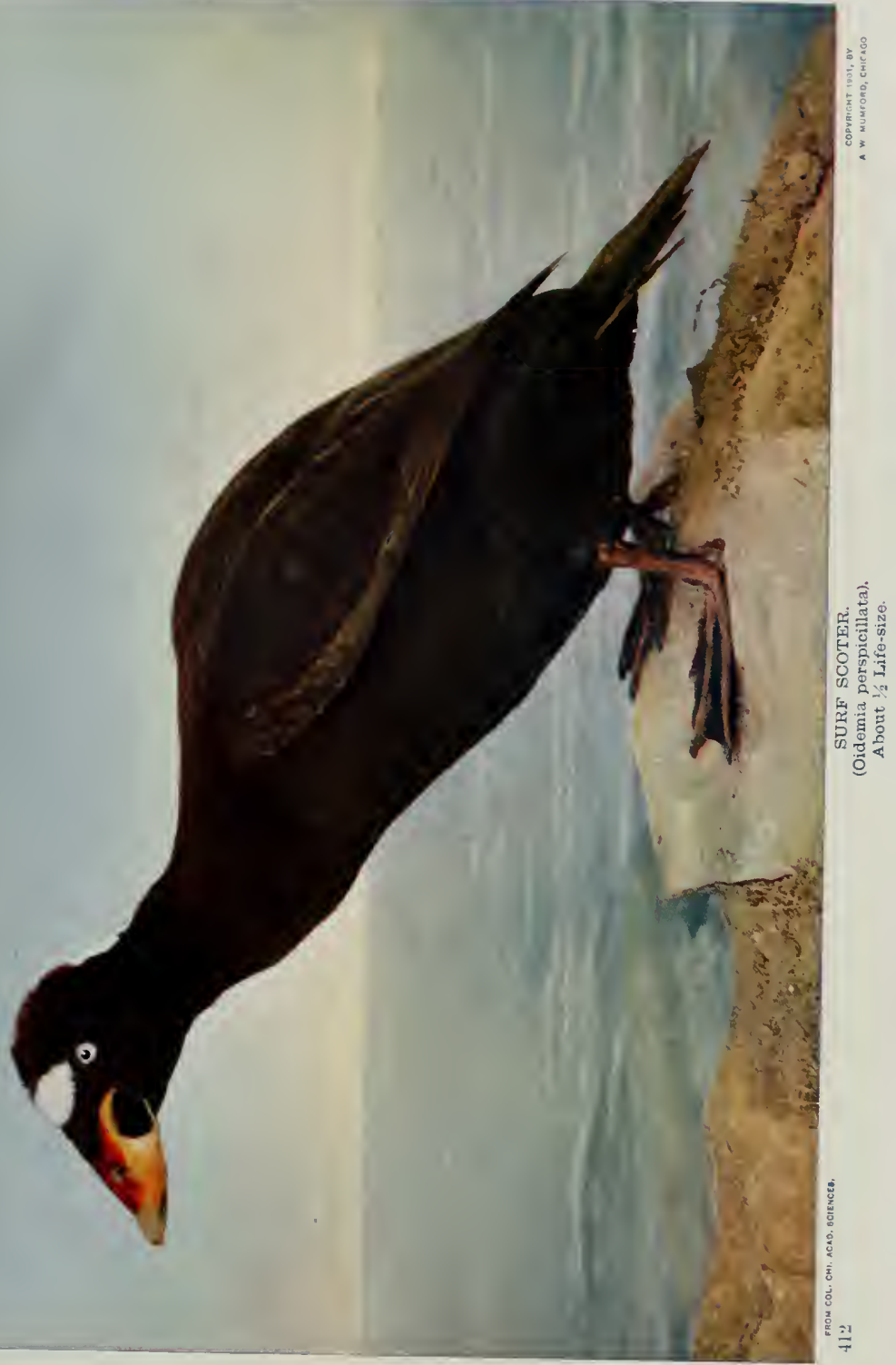





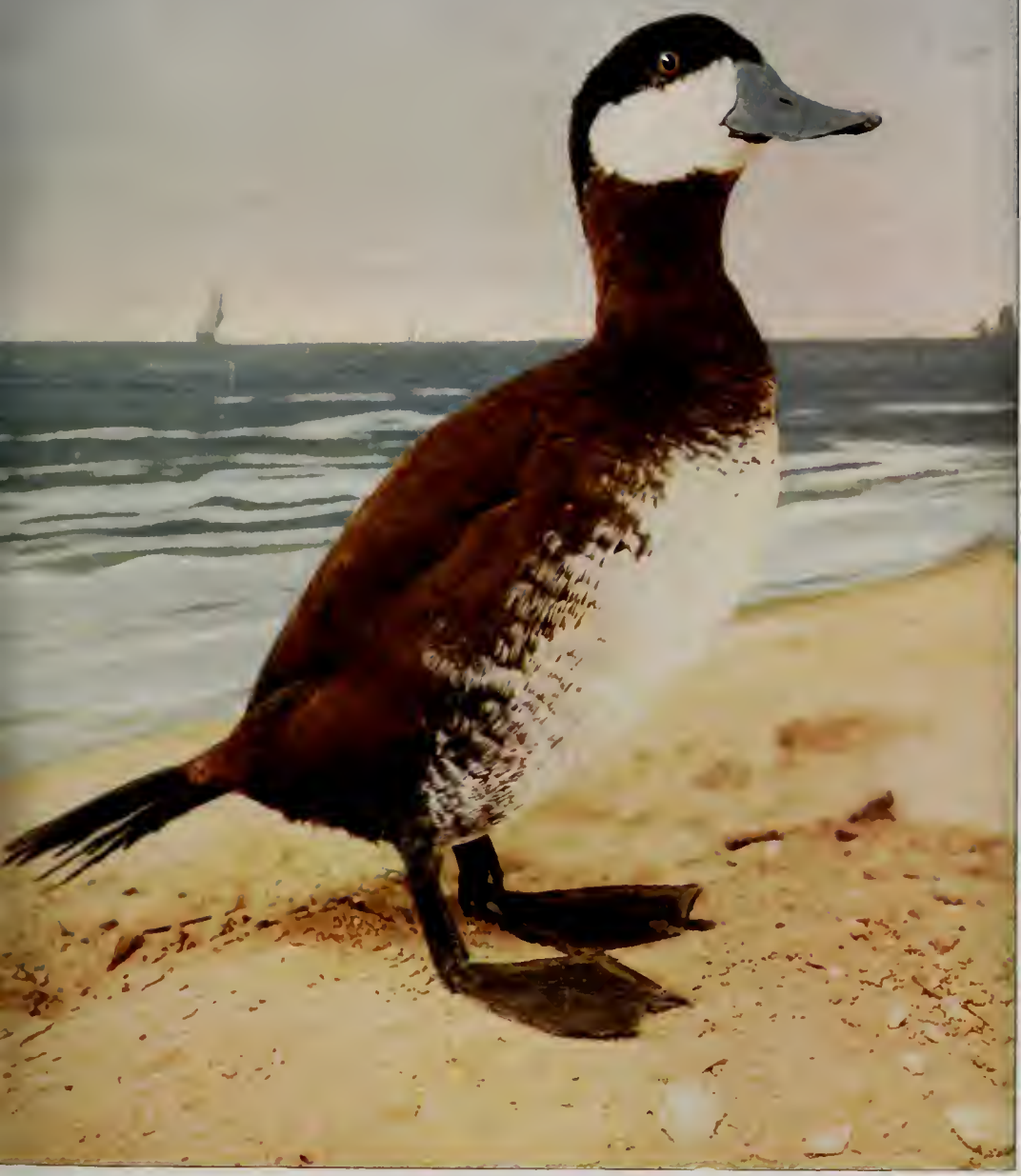



Its nest, usually placed on grassy knolls, in fresh-water marshes near the sea, is made of dricrl weeds and grasses and lined with the down of the bird. It is evident that the female performs all the duties of incubating the eggs and caring for the young, for during the nesting period large flocks are observable that consist entirely of males, constantly feeding in their accustomed haunts.

This ocean duck feeds "on small mollusks and fishes, for which it dives almost constantly, both in the sandy bays and amidst the tumbling surf, sometimes fishing at the depth of several fathoms and floating buoyantly among the surf of the raging billows, where it seems as unconcerned as if it were on the most tranquil waters."

\section{RUDDY DUCK}

The Ruddy Duck is distributed generally from northern South America to Hudson Bay, breeding mostly in Canada, though locally farther south. This duck is more common west of Indiana and Michigan. In the Great Lakes region they are known chiefly as migrants, but in Utah, Colorado, and California this odd-looking duck is a summer resident. They frequent both fresh and salt water, flying low over the surface.

Ruddys are comparatively small ducks with flat bodies and stiff tail feathers held erect while swimming. The feet are extremely large, and the birds swim rapidly both under and above water. In rising it runs on the surface of the water against the wind.

Like the redhead and canvas-back, this bird constructs 
a floating nest, from which the parent quickly swims at the approach of danger. The eggs, six to twelve in number, are immense for the size of the bird, even exceeding those of the large mallard and canvas-back. The granulated shell lacks the oily polish found on most duck eggs.

\section{THE WHITE-FRONTED GOOSE*}

White-fronted or Laughing Geese are found in considerable numbers on the prairies of the Mississippi Valley. They are called Prairie Brant by market-men and gunners. Though not abundant on the Atlantic seaboard, vast flocks may be seen in the autumn months on the Pacific Slope. In Oregon and northern California, some remain all winter, though the greater number go farther south. They appear to prefer the grassy patches along streams flowing into the ocean, or the tide-water flats so abundant in Oregon and Washington, where the Speckle-bellies, as they are called, feed in company with the Snow Geese. The nesting place of this favorite species is in the wooded districts of Alaska and along the Yukon River. No nest is formed, from seven to ten eggs being laid in a depression in the sand.

It is said that notwithstanding all references to their ungainly movement and doltish intellect, the wild goose, of which the white-fronted is one of the most interesting, is held in high estimation by the sportsman, and even he, if keen of observation, will learn from it many things that will entitle the species to advancement in the mental grade. There is probably no bird more cautious, vigilant, and fearful at danger than this. 



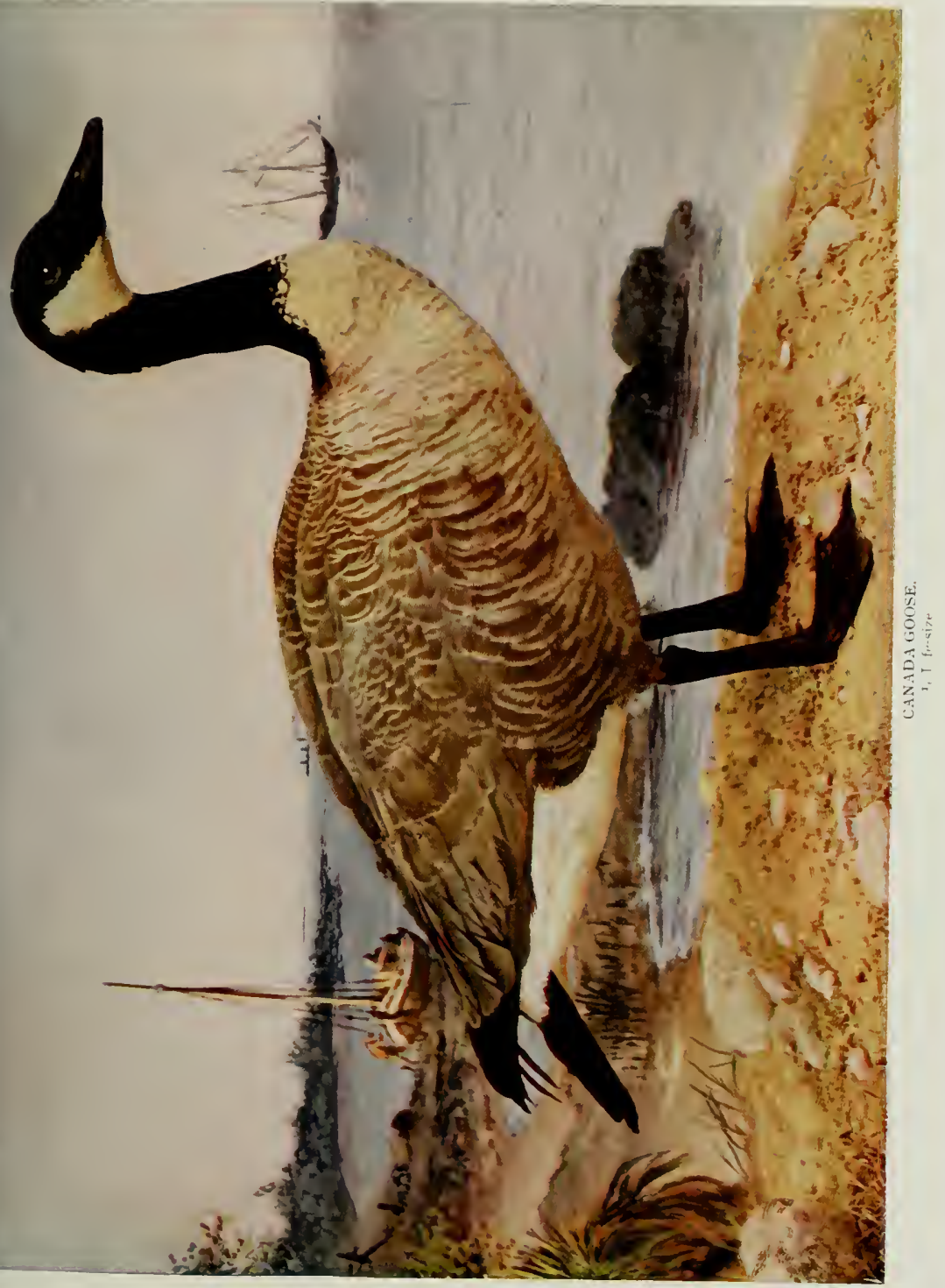



The white-fronted goose is greatly esteemed for the excellent quality of its flesh, which, by those who have learned to appreciate it, is generally considered superior to that of any other species. While the cruel pursuit of the bird merely for purpose of sport ought not to be continued, appreciation of its value as food may well be encouraged.

\section{CANADA GOOSE}

The Canada Goose ranges throughout temperate North America, breeding in the West, on the ground or sometimes in trees near streams.

This is the typical wild goose, and, in the estimation of many sportsmen, the wariest and gamiest of the feathered tribe. In the fall and early spring, large flocks of these geese may be seen moving slowly overhead. It is the general supposition that these "honkers" are on the way north or south, but they are much hardier than we generally suppose. Many Canada geese winter about Lake Michigan, spending the day far out in open water where there is no danger of molestation. At sundown they rise in $\mathrm{V}$-shaped flocks and move inland to feed in grain fields.

Because of its intelligence, the Canada goose gives promise of holding its own despite the increase of gunners. It would be a shame to lose this picturesque and stately bird, as the United States can now claim few as summer residents, while fifty years ago it was with us twelve months in the year.

In 1900, while collecting in North Dakota, I unexpectedly chanced upon a pair of these birds leading five downy 
young across the prairie not far from open water. I hastened toward the group, when the old birds rose and flew toward me, flapping about my head in a threatening manner; a bird with such strength of wings is capable of putting up quite a fight. As I stood watching the antics of old birds, the goslings reached the lake and swam rapidly from shore. It was an impressive sight to see these two naturally shy birds so fearless of man in their efforts to protect their offspring.

Many geese do not breed until they are two years old, which fact may explain the presence of small flocks in breeding season in temperate regions where they are not known to nest. I have six large white eggs of the Canada goose, taken in Illinois some years ago, when a few still nested along the Mississippi. The nest was placed on the ground at the edge of a little pond not far from the "Father of Waters."

On the lakes of Manitoba, these birds construct their huge nests on the islands in company with herring gulls and cormorants. The nests are composed of weeds and debris, warmly lined with down from the breasi of the parent.

\section{THE BLACK BRANT OR BRANT GOOSE*}

The Black Brant, or the Brant Goose, as it is frequently called, is not the brant of the Atlantic coast, but a western bird, ranging from Lower California to the Arctic region of North America. On the Atlantic coast it appears only as a casual visitor, and it is not found in the interior. It makes its summer home in very high latitudes and on the 


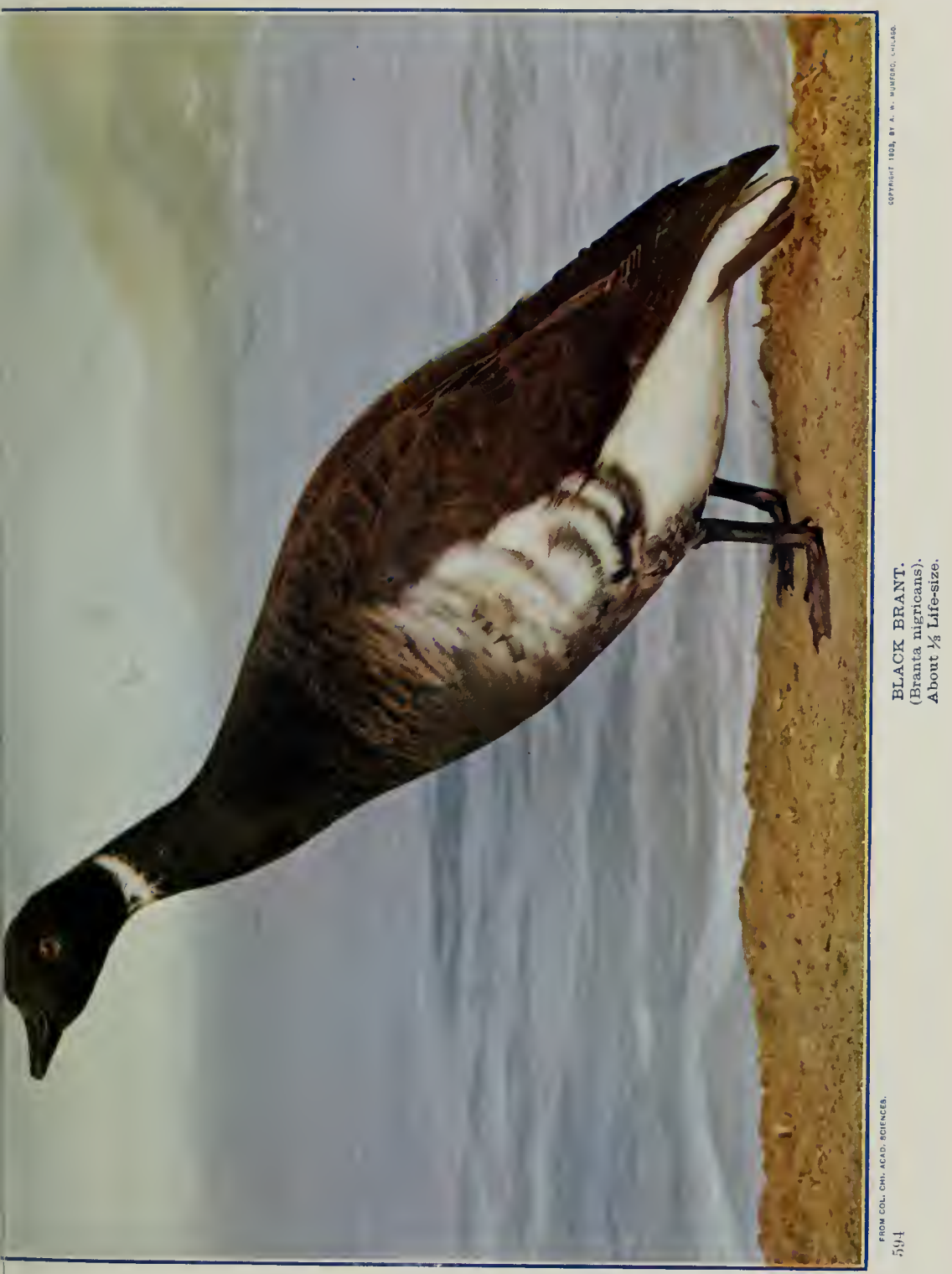



Pacific coast; the southern limit of its nesting range seems to be about the latitude of the mouth of the River Yukon. Dr. William H. Dall has said that in the spring it comes in immense flocks to the sea coast of Alaska, and he found the crop of one of these birds to be full of small crustaceans, though, as a rule, it partakes only of a vegetable diet, feeding chiefly upon eel-grass.

During the time of low tide the brant feeds constantly, tearing up the plants by the roots from the muddy flats. Unlike the sea ducks, it does not dive for its food, and it is said that it will never dive except when wounded. It passes the night hours floating on deep water in the open sea. It is a noisy bird, and quarrelsome with its kind. Being of a very inquisitive nature, it is easily attracted to decoys. It is, therefore, one of the easiest marks for the hunter; and consequently there are an exceedingly large number of these toothsome geese shot each year for the markets.

Its note is "hoarse and honking," and when a flock gabbles in company, as they often do when feeding, the sound cannot be described better than to call it a perfect din.

It is said that the nest of the black brant is usually situated in a depression in the ground and consists of grasses and moss, lined with down.

Both the black brant and its eastern relative (Branta bernicla) are sometimes called "barnacle geese." This name is said to have had its origin in a fable which narrates that they were dereloped out of barnacles attached to wood in the sea. Dr. Coues says that the name brant means burnt, and it was given to these birds because of their dark color, which suggests charring. 


\section{THE FULVOUS TREE-DUCK *}

The Tree-ducks are natives of tropical or semi-tropical countries. Two species are found in the United States, the bird of our illustration and the Black-bellied Tree-duck. The range of the fulvous species extends from the southern border of the United States, and in Nevada and California, southward through Mexico, and reappears in the southern portion of Brazil and in the Argentine Republic. It has also been reported as a visitor to the States of North Carolina and Missouri.

Mr. Frank M. Woodruff, in speaking of his experience while on a collecting tour in Texas, says: "I found the Fulvous Tree-duck in small numbers resident on Galveston Island, but found them abundant and nesting in the heavy timber along the Brazos River, sixty miles from Galveston. In the early morning, as we would leave our boat and make our way to our blinds, on some small inland pond where we had prepared for collecting, we would flush immense flocks of this duck, which would fly over our heads at rather a low altitude, and continuously calling. On several occasions we obtained specimens by firing into a flock while it was still so dark that we could scarcely define the outlines of the individual birds. The fulvous tree-duck generally feeds in the night, and usually at a place several miles from the nesting site. They leave the feeding grounds on the first sign of approaching day. During my stay of three months in the Brazos River region, only on one or two occasions did I have an opportunity to observe this bird by 

the light of day. In form it resembles a miniature swan. It stands very high on its legs and presents a wonderfully curious and graceful appearance as it walks along the shore, feeding on shellfish and decaying matter.

"Owing to the nature of its diet, which consists chiefly of grain, roots, and water plants, the flesh of this bird is esteemed as an article of food, and many are killed for such.

"Nest: Located in the hollow of a tree, the bottom of the cavity usually being lined with feathers. They lay from ten to fifteen pure white eggs, and as many as thirty-two have been found in one nest, but these were probably laid by two or more females." 


\section{,}




\section{CHAPTER VI}

WADING BIRDS

Flamingoes are tropical birds. Of the seven species included in the order, only one reaches North America. Flamingoes are gregarious throughout the year. Feeding in shallow bays or mud flats, they are rarely found far from the coast. They feed similar to ducks, having same strainer nature of bill.

Spoonbills are mostly tropical birds, only one species inhabiting the United States. They are gregarious, nesting in colonies. While general habits resemble those of the herons, they immerse their large, flat, sensitive bill and feed by swinging it from side to side.

Ibises are usually tropical birds. Of thirty species, only four are to be found in North America. These silent, gregarious birds feed along the shallow lagoons, bays, and mud flats, usually of salt water. The peculiar bill is adapted to taking and crushing crustaceans; it also eats frogs, small fish, and reptiles.

Herons and bitterns have a general distribution, though they are most numerous in the tropics. Herons are gregarious; even when they feed singly they nest and roost in flocks. Bitterns are usually found singly or in pairs. They select grassy marshes for feeding, while herons prefer the shores of sea, lake, or river. Protective attitude and color of bitterns are marked. Some herons await their prey in 
shallow water, while others run through water and carry on an aggressive campaign, spearing frogs and fish as they attempt to escape. Herons fly with neck arched over shoulders.

\section{FLAMINGO}

Flamingoes are tropical or sub-tropical birds distributed throughout favorable sections of the Atlantic coast of both hemispheres. Five varieties are American, only one of which reaches North America. 'They are gregarious birds and are to be found in colonies during both the breeding and migrating seasons. Showing a decided preference for still and brackish water, one seldom encounters these large birds far from the sea coast.

The construction of the strainer bill is peculiar; the portion joining the head is almost at right angles with the outer half of the beak. The beak of the young is straight like that of a duck, gradually assuming an angle. Their mode of separating the edible matter from the waste is the same process used by ducks, but of course the latter pushes the bill forward as a spade, while the former uses the bill more as a hoe because of long neck.

The plumage is light salmon, bordering on pink or light rose. The feathers on some parts of the body are lighter. In confinement and in mounted specimens the plumage loses the bloom so that the feathers become several shades paler. This undoubtedly is due to the lack of some essential article obtained in the natural diet when in the wild state.

These birds nest in the islands south and east of Florida. Extensive mud flats slightly flooded at high tide are the 


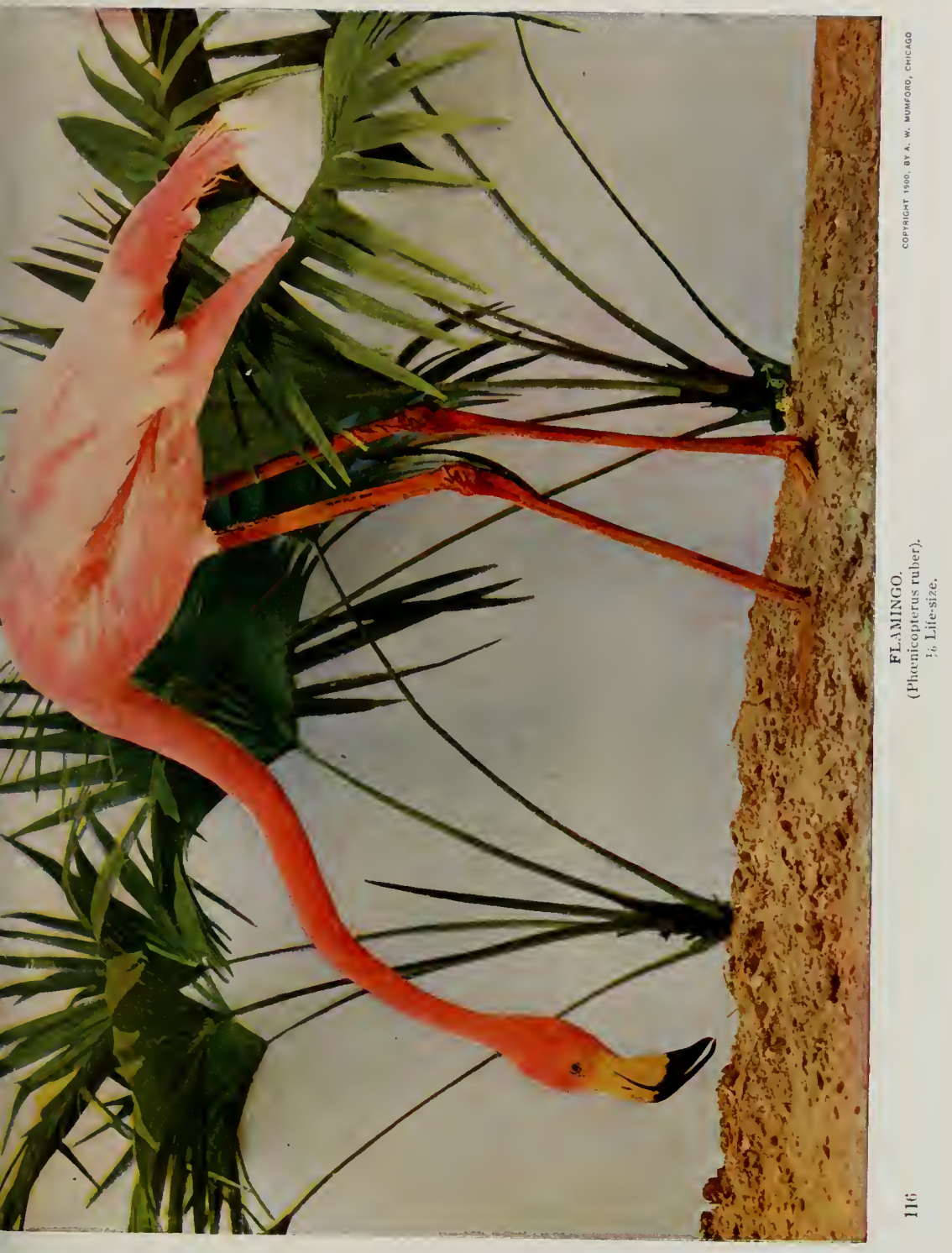





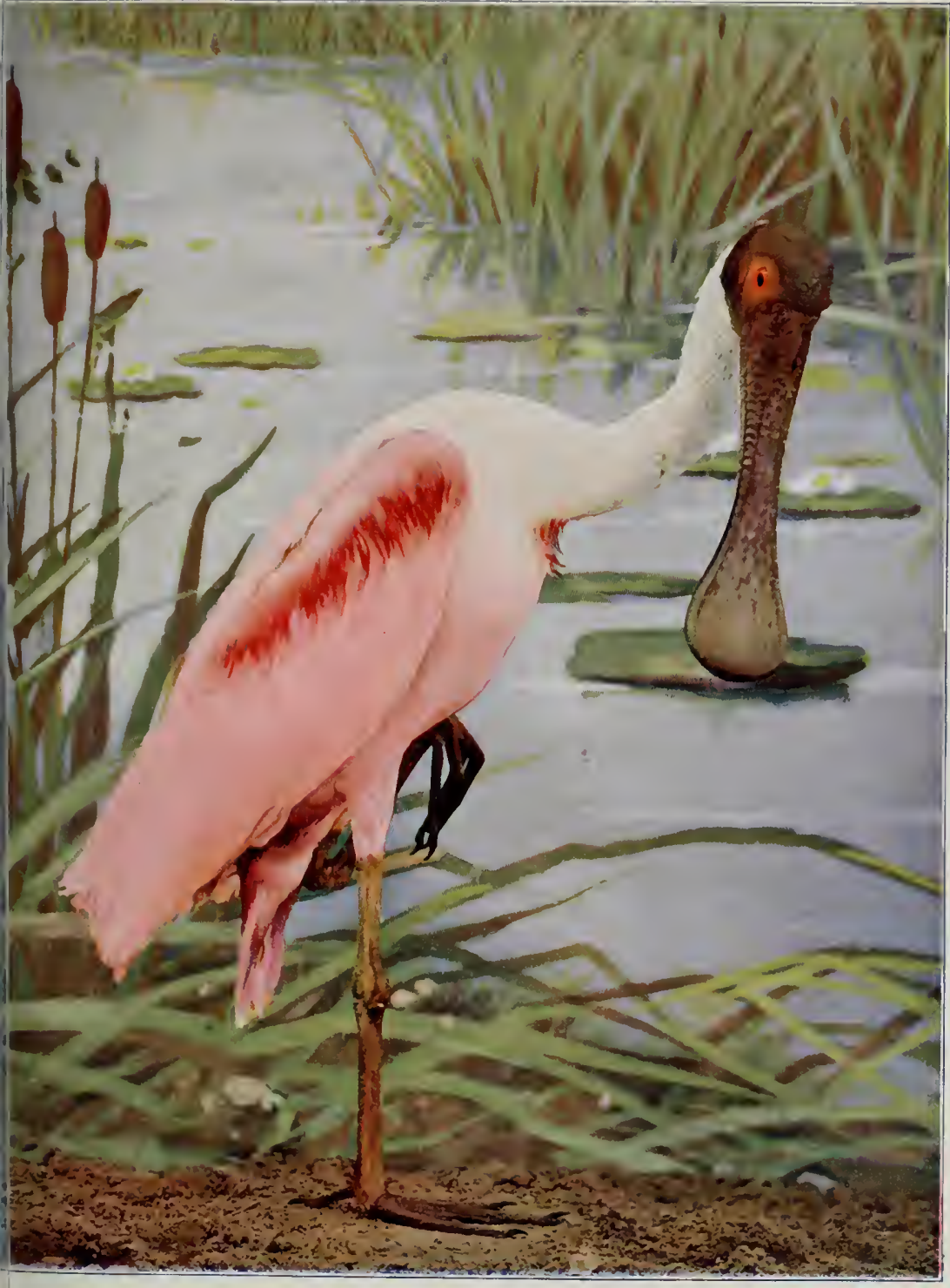



favorite nesting grounds. Scraping together a quantity of the wet earth until there is an elevation of from six to twelve inches, it is slightly hollowed at the top, but not lined. While incubating her single egg, the female folds the legs under the sides, as do other long-legged birds, thus dispelling the popular belief that the flamingo sits astride her nest.

The long, white or pale greenish-white eggs have the surface so thickly coated with soft lime that the chalky substance is left on the hand when handling specimens.

Occasionally these birds in their wanderings touch the extreme southern coast of Florida, but they do not breed on that peninsula.

\section{ROSEATE SPOONBILL,}

These beautiful aquatic birds are found both on the coast and in the interior. Of the half-dozen varieties of spoonbills, the Roseate Spoonbill is the only form inhabiting North America. Their range is becoming more restricted yearly. Years ago the species occurred in southern Illinois and Indiana. About the only section of the United States where this bird is now found in any numbers is along the gulf coast of Texas, ranging from there southward into South America. The principal cause for the extinction of this species in most of its former range is beauty, the same cause that led to the fate of the snowy herons, slaughtered for the "aigrettes."

Like our large herons, they are gregarious, but their mode of feeding is entively different from that of our other American birds, except the avocet. They feed by swinging 
the bill from side to side through the water; the edges of the sensitive mandibles recognize the nature of substances touched, so that the bird finds food in muddy water.

In former years the spoonbills nested in large colonies in various swampy places in Florida. A large, bulky structure of sticks is usually arranged by the birds in small shrubs and little trees growing in or near the water. Three or four eggs are usually laid, the background being white and the markings light brown.

\section{WHITE IBIS}

The White Ibis resembles the ancient sacred ibis of the Nile, while in habits it resembles the heron, crane, and bittern. Inhabitants of warm climates, in America their range is becoming restricted yearly. Four varieties occur in North America; the wood ibis and the white-faced, glossy ibis, like the white ibis, are peculiarly American, while the scarlet ibis is an accidental visitor. Some years ago the white ibis was found in the southern swamps of Illinois and Indiana. Of late years they have retreated to the wooded sections of Florida, Texas, and other Gulf States.

Ibises are gregarious, but, unlike the herons and cranes, are almost silent birds. Their food is chiefly animal matter, such as frogs, crawfish, and minnows. Their large beak is well adapted for extracting and crushing crawfish.

The flight of the white ibis, like that of the white pelican, is picturesque. They move in close ranks, alternately flapping and sailing, all birds moving the wings simultaneously. As they pass through the sunlight the plumage glistens and 

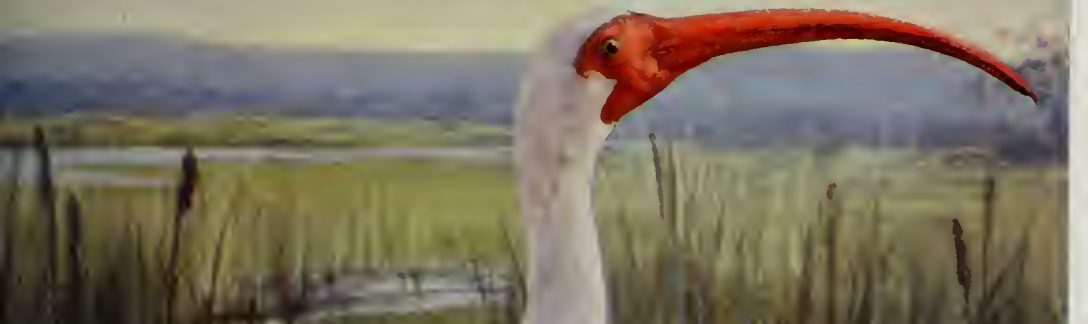
1.1. 



the black markings on the wings show in marked contrast to the otherwise immaculate plumage.

Their nests are placed in low thickets, frequently above the water. Like the nest of the heron, it is a rude affair of sticks and moss, arranged in the form of a platform, with a slight depression in which three or four bluish-white eggs are laid. The eggs are heavily blotched with scarlet, but the markings appear somewhat smeared, giving the eggs a dirty appearance.

\section{THE SCARLET IBIS*}

Ibises are distributed throughout the warmer parts of the globe and number, according to the best authorities, about thirty species, of which four occur in North America. The scarlet ibis is a South American species, though it has been recorded from Florida, Louisiana, and New Mexico. The ibises are silent birds and live in flocks during the entire year.

They feed along the shores of lakes, bays, and saltwater lagoons, and on mud flats over which the tide rises and falls. Their food consists of crustaceans, frogs, and small fish.

Colonies of ibises build nests in reedy marshes, or in low trees and bushes not far from good feeding-grounds. Three to five pale greenish eggs, marked with chocolate, are found in the coarse, bulky nest of reeds and weed stalks.

These birds are not so numerous as they once were. They have been wantonly destroyed for their plumage alone, the flesh being unfit for food. Their beautiful plumage is the cause of their rapid extinction. 


\section{THE IVHITE-FACED GLOSSY IBIS*}

Only the most meager accounts exist of this little known and irregularly distributed species. It remained undiscovered in America until 1817, when Mr. Ord took a specimen on the eastern coast of New Jersey. Although at first described under a new name, it is now known to be identical with the Old World species, which thus enjoys a wide and rather remarkable range. (Dawson.)

The beautiful, lustrous White-faced Glossy Ibis inhabits the southwestern United States and tropical America. It is found as far north as Kansas and west through New Mexico and Arizona to California. In southern Texas it is very abundant, and in some localities along the banks of the Rio Grande swarms by thousands. The nests and eggs of the ibises are quite unlike those of any of the lierons, and can be distinguished at a glance. The nests are made of broken bits of dead tules, supported by and attached to broken and upright stalks of living ones. They are rather well and compactly built, quite unlike the clumsy platforms of the herons. The eggs are nearly always three in number.

The walk of the ibis is quiet and deliberate, though it can move over the ground with considerable speed whenever it chooses. Its flight is lofty and strong, and the bird has a habit of uttering a loud and peculiar cry as it passes through the air.

The food of the ibis consists mostly of mollusks, both terrestrial and aquatic, but it will eat worms, insects, and probably the smaller reptiles. 


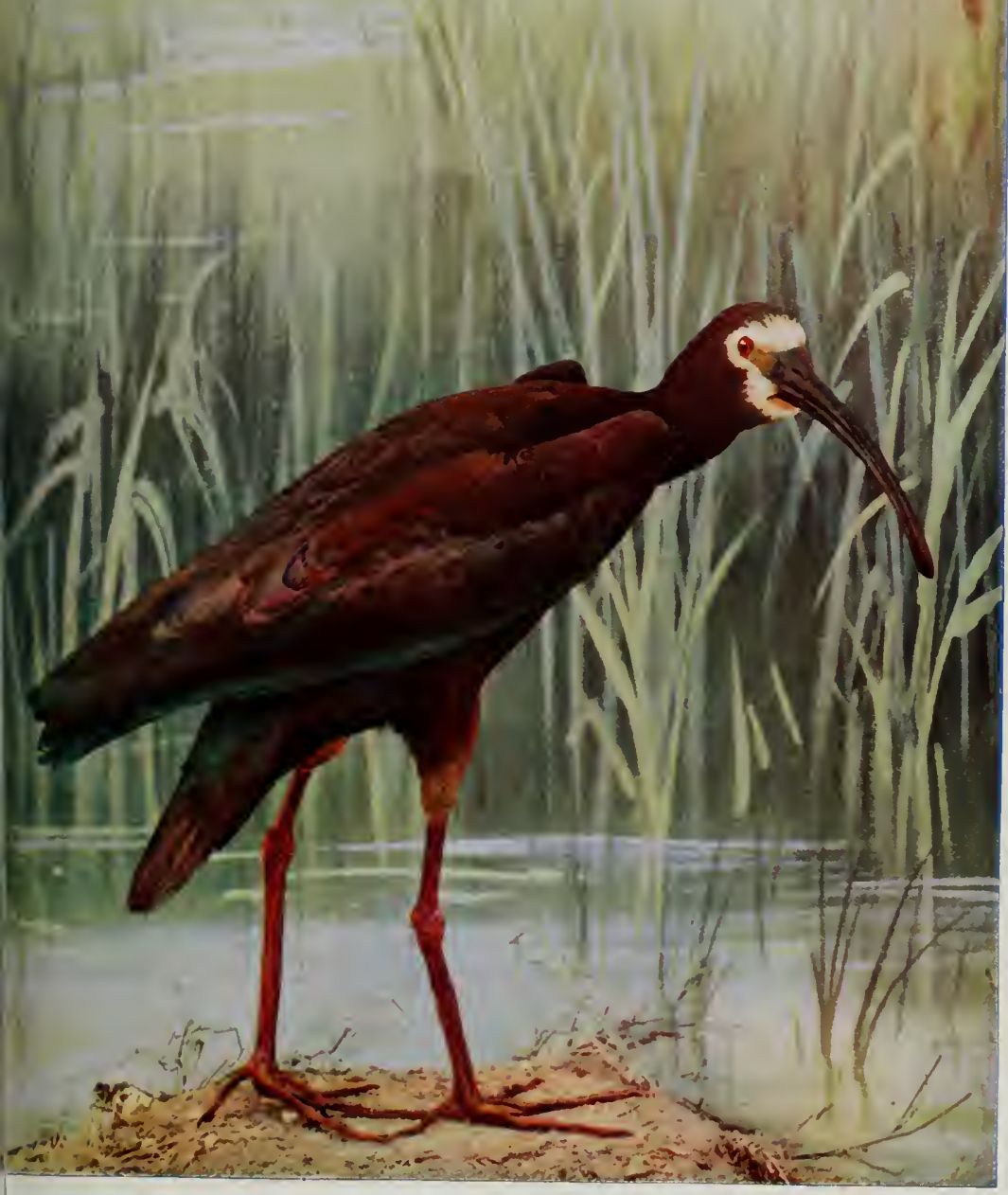

WHTE-FACED GLOSSY IMIS 



The sexes have similar plumage, but the female is smaller than her mate.

\section{BITTERN}

The Bittern ranges throughout temperate North America and winters from Virginia south.

One of the most familiar marsh birds, it is known under many aliases, such as thunderpump, Indian hen, stake driver, and bull goose. This interesting creature is not a game bird, but because of its sluggish nature is often the victim of the ruthless hunter. To escape detection, bitterns assume a pose extending the head and neck skyward, thus resembling a stump with a dead sprout at the side. Bitterns stand motionless for hours in shallow water, until some fish, frog, or reptile comes within striking distance.

This bird breeds commonly throughout the East and Middle West, from New York, Illinois, and Iowa northward. The nests are usually composed of dead reeds and rushes, a mere platform with little or no cavity. From three to six eggs are laid, and the period of incubation is twentyone days.

During the mating season the birds produce a remarkable vocal sound, not unlike that produced when driving a stake with a hammer. This performance has earned them the title of "stake-driver." The notes run something like this: "Quack, chunk, chunk, quack, quackalunk, chunk, chunk, quack um chunk, quack, quackalunk, chunk."

One excited female bittern disgorged eleven crawfish and seven frogs before I could persuade her to vacate her nest, which contained five coffee-brown eggs. 


\section{LEAST BITTERN}

The Least Bittern ranges throughout temperate and tropical North America, wintering south.

This beautiful bird is of a retiring disposition, though not averse to living in a noisy environment, provided it is unmolested in its home among the tall grasses and rushes of marshes. Several authors speak of the least bittern as a "silent bird," although the writer has frequently seen and heard it utter a peculiar "squeak," especially if suddenly approached. It loves to lurk in the reedy borders of boggy ponds and marshy lakesides where gallinules and rails abound. An interesting habit of this bird is that of perching on an upright reed, where, with its neck extended, it remains motionless, closely resembling in color and form a bunch of dead reeds, in order to escape detection. While pushing my boat among the rushes during a rainstorm I once saw a least bittern roosting in a clump of vegetation, with its head drawn between its shoulders, oblivious to its surroundings. I gently touched it, when "Rock, rock!" it seemed to call, and in its sudden efforts to escape lost its equilibrium and fell into the water.

Its nest of grasses, etc., is placed among reeds or in a small bush; three to six bluish-white eggs are laid.

\section{GREAT BLUE HERON}

The name Great Blue Heron, often called Blue Crane and Sand Hill Crane, is misleading, as the prevailing color of the adult is slaty gray. 


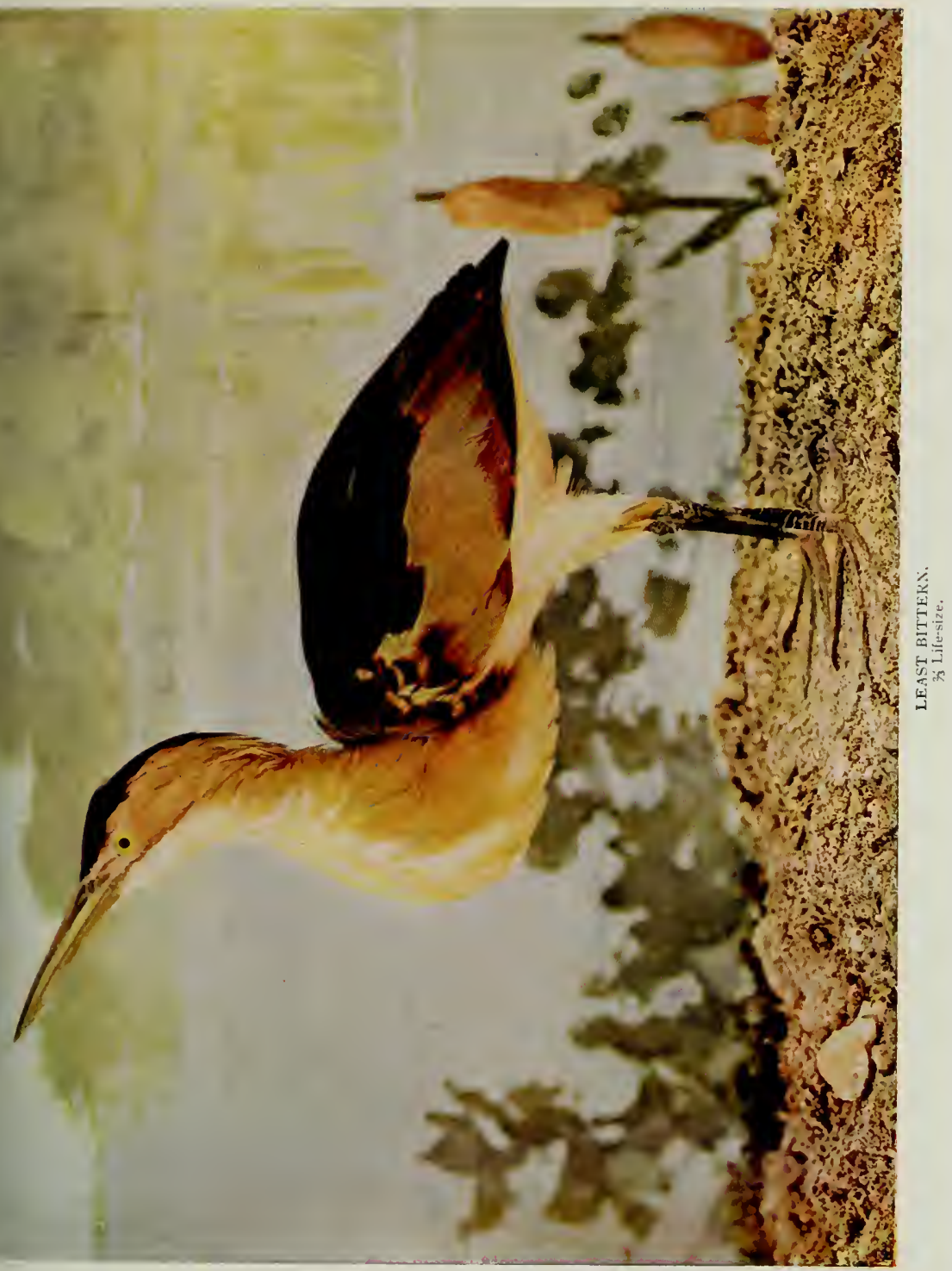





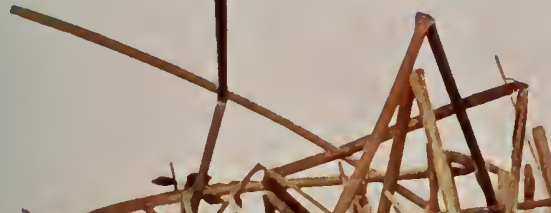

- Fo A 14.

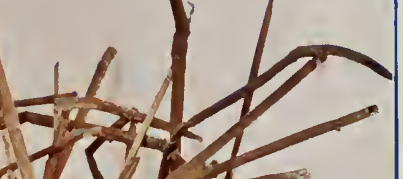

1 (n)

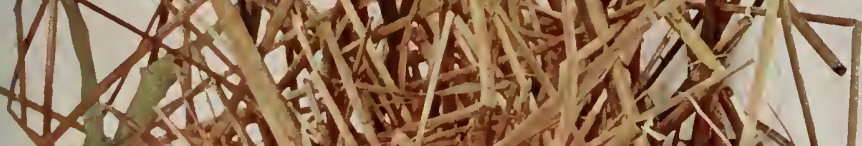

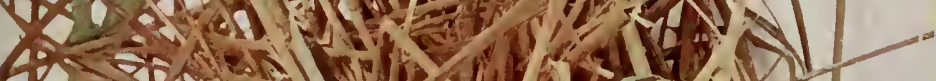

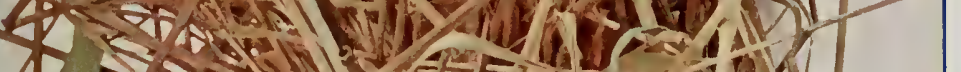

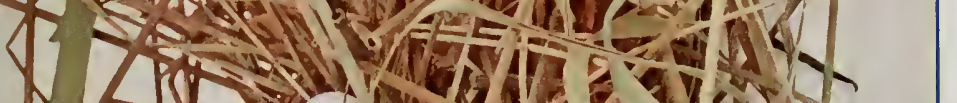

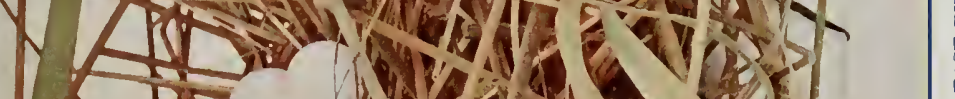

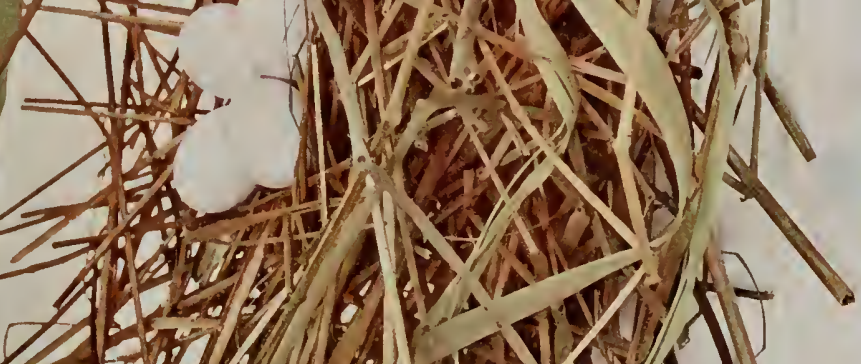





This bird is found from the Atlantic to the Pacific, breeding in colonies north of the Ohio River, throughout the Great Lakes region, and the Canadian provinces. It winters from Middle States southward to northern South America. River bottoms and tamarack swamps are resorted to immediately upon their arrival from the South in April. The birds travel great distances to fish, usually singly. Unlike the bitterns, herons do not stand motionless waiting for their prey to come within reach, but move about in shallow water, striking with their bill any form of animal life that appears near the surface.

Their notes are coarse, discordant croaks. This species is not suffering destruction at the hands of the plume hunter, so are still found in great numbers along the river bottoms of the Kankakee and the Illinois.

Places where they assemble to nest are called "heronries." Some huge trees contain as many as forty nests, all of which may be occupied at the same time; the ground or shallow water beneath these nesting trees is offensive with decaying fish.

The trees occupied by the nests usually die after the second or third year, but the nests are used after the trees are dead. The three to five light blue eggs require four weeks' incubation, and the young leave the nest after sixty or seventy days. In some of our treeless sections these birds have adapted themselves to conditions by constructing huge nests on the ground. The writer saw a colony of about two hundred pairs along the Yellowstone River in Montana, and several other heronries exist on the barren alkali tracts of California. 


\section{THE SNOWT HERON*}

Temperate and tropical America, from Long Island to Oregon, south to Buenos Arres, may be considered the home of the Snowr. Heron, though it is sometimes seen on the Atlantic Coast as far as Nora Scotia. It is supposed to be an ocessional summer resident as far north as Long Island, and it is found along the entire Gulf Coast and the shores of both oceans. It is called the Little White Egret, and is no doubt the handsomest bird of the tribe. It is pure white, with a crest composed of many long, hair-like feathers, a like plume on the lower neck, and the same on the back, which are recurred when perfect.

Snowy herons nest in colonies, preferring willow bushes in the marshes for this purpose. The nest is made in the litter part of April or early June. Along the Gulf Coast of Florida ther nest on the Mangrore Islands, and in the interior in the willow ponds and swamps, in company with the Louisians and Little Blue herons. The nest is simply a platform of sticks, and from two to fire eggs are laid.

Alas! plume hunters hare wrought such destruction to these lorely birds that very few are now found in the old nesting-places. Ther will soon become extinct unless the barbarous practice of wearing feathers be stopped.

The little egret mores through the air with a noble and rapid flight. It is curious to see it pass directly orerhead. The head, bodr, and legs are held in line, stiff and immorable, and the gently waring wings carry the bird along with a rapidit? that seems the effect of magic. 


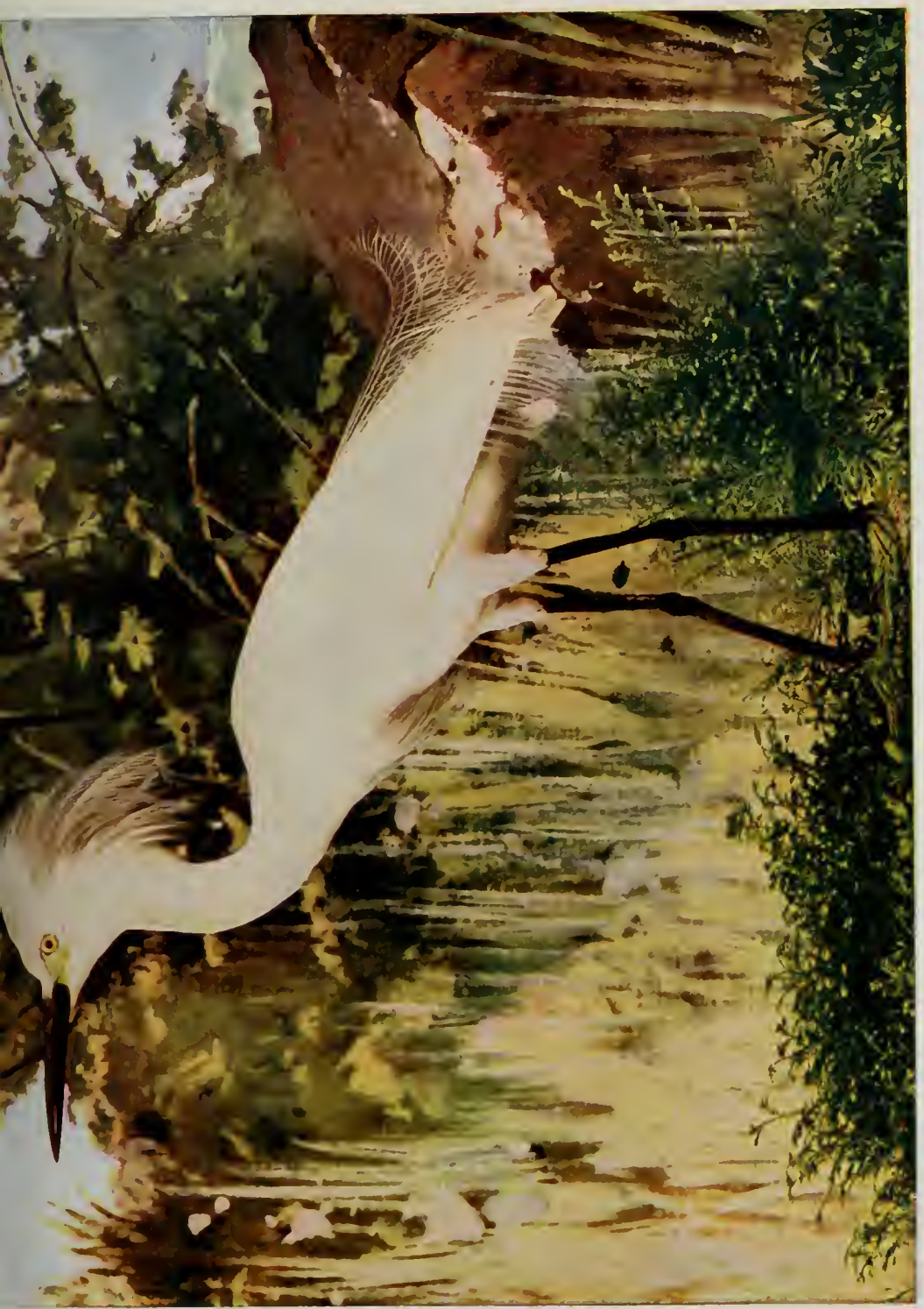





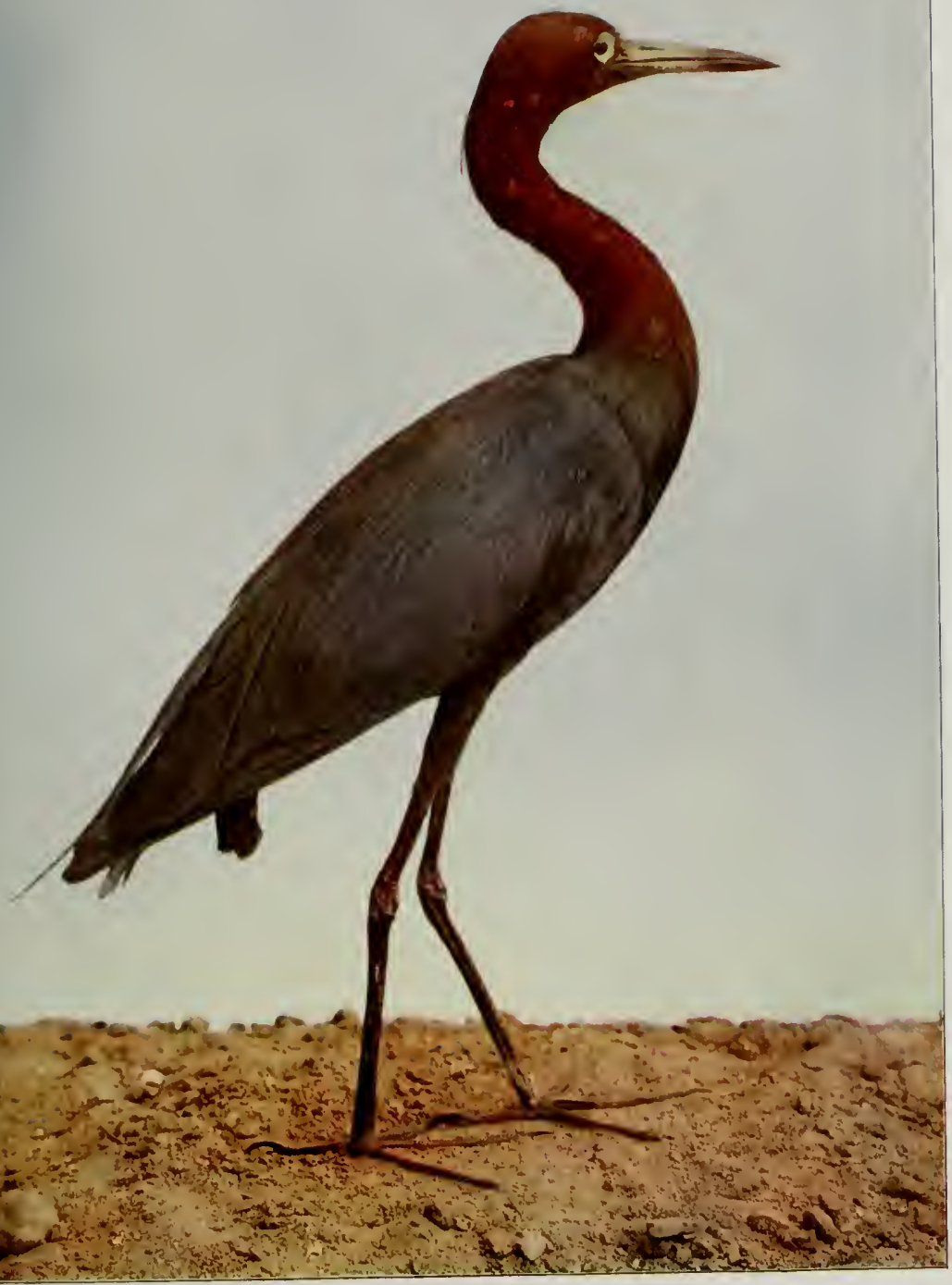



The Little Blue IIeron is found from New York, Illinois, and Kansas southward through Mexico and Central America to South America and the West Indies. It is of accidental occurrence as far north as Maine and Wisconsin.

The name "little blue" is somewhat misleading, as adult birds are a maroon color on the head and neck; the rest of the plumage is grayish or slaty. Imnature birds are pure white, with the exception of a faint grayish tinge near the tips of the wings. The young, therefore, look very much like the snowy egret.

These birds often breed in company with snowy and Louisiana heron. Their eggs, like those of all other herons, are light blue, unspotted. The nests are mere platforms of sticks. The writer has four eggs taken from a nest placed eight feet above the water, in a willow where yellowcrowned night herons were nesting in company with the little blue herons, in one of the Georgia swamps.

\section{THE LITTLE GREEN HERON*}

One of the smallest of the herons, and one of the most common in many localities, is the Little Green Heron, familiarly known to the rural Hoosier boy as the "Schytepoke" and to others as the "Poke."

The little green heron arrives in the Northern States and Canada from its winter residence in Florida, or farther southward, about the last of April, and immediately begins 
nesting, selecting, if convenient, second-growth timber, especially if there be a thicket of undergrowth. But if these conditions be not at hand, it seems to prefer, as a site for its nest, an old, abandoned orchard, or at least one somewhat remote from human habitation, but not very far distant from a stream or pond. In the fork of some tree, ten to twenty feet above ground, is collected a considerablesized but irregular and loose bundle of rough sticks. In this, by the middle of May, or at times even earlier, it lays from three to six greenish-blue eggs, about an inch and a half long by an inch and a quarter in diameter.

It is quite interesting to see one of these herons feeding. It will wade along the edge of a pond or stream, very slowly lifting its feet out of the water and carefully putting them down again. Its neck is folded so that it almost disappears, the head being drawn back against the shoulders. At last it sees an unwary minnow swimming lazily along. Slowly and carefully it leans its body forward and downward toward the water, the long legs looking and acting almost like stilts; still more slowly the head, with its long, stout beak, moves cautiously toward the water surface, very much like a young turkey seeks to capture a grasshopper. Then, suddenly, as if a spring had been set free in its neck, the head is thrust downward until the beak, or more, disappears beneath the surface, but only to reappear immediately with the struggling minnow or sunfish between its mandibles, and walking out on the bank a safe distance, with two or three strokes of his strong beak he stuns the fish, which in another moment has started head first down the heron's throat.

Henry H. Lane. 


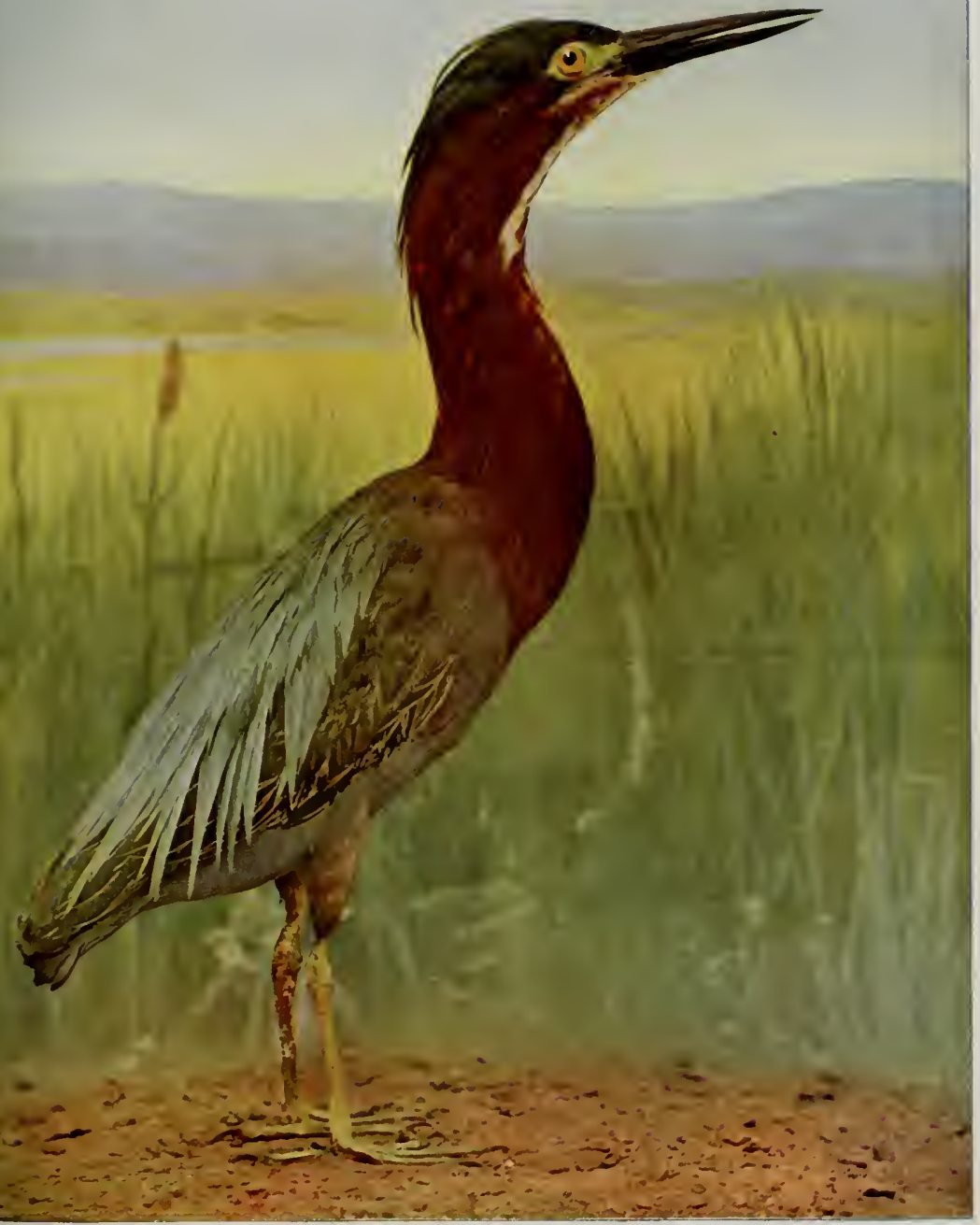

GREEN HERON.

COPVAIOHT 1902, GY A W. MUMFOMO, CHICAgO

About iz Life-size. 


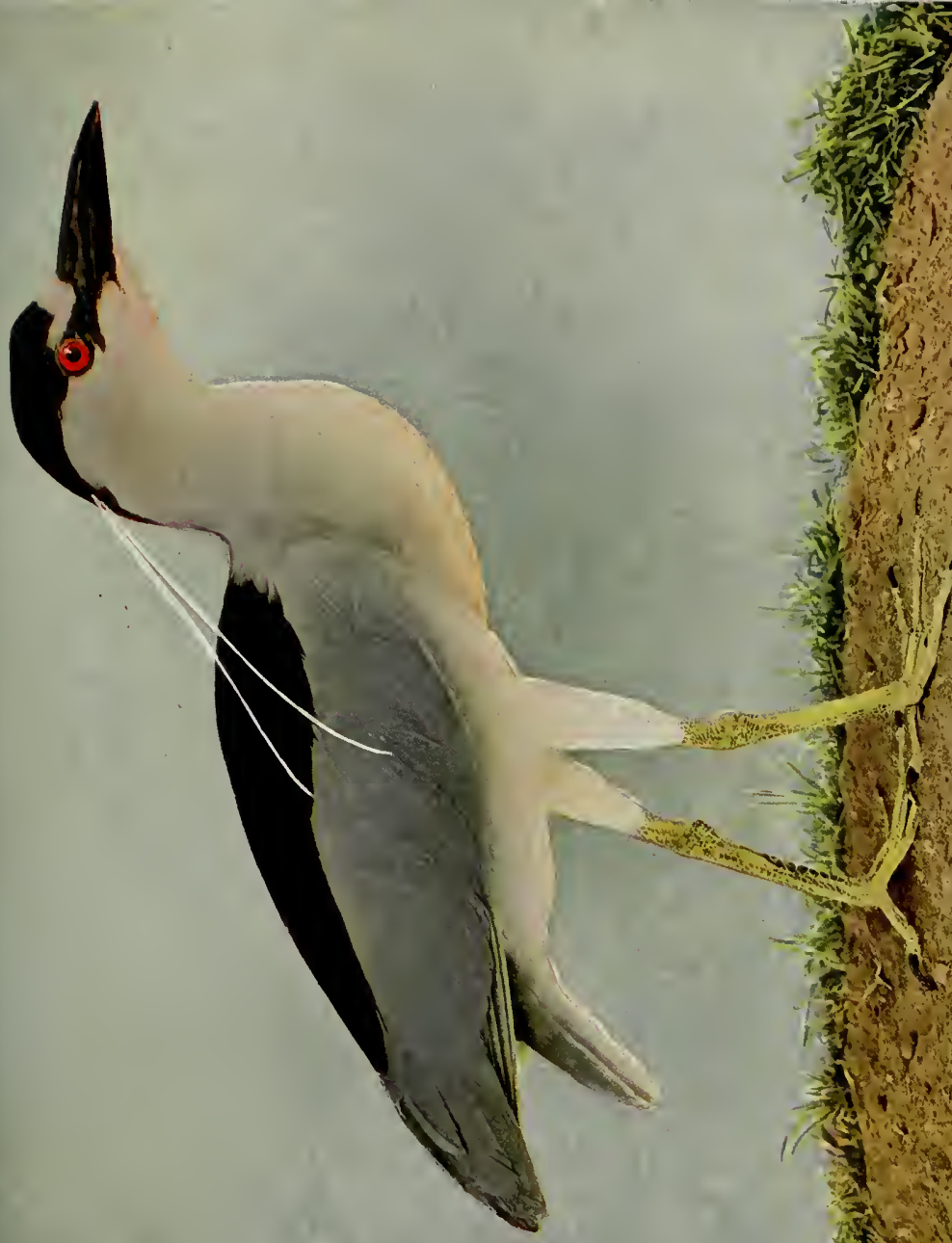



\section{BLACK-CROWNED NIGHT HERON}

The Black-crowned Night Heron, or "Quawk," breeds chiefly in the United States; it also breeds in southern Canada from New Brunswick to British Columbia, wintering from the Gulf States to South America.

This bird might more properly be called the bridled heron, as the males have two feathers, four to eight inches long and scarcely one-tenth of an inch in breadth, attached to the back of the neck. The name "black-crowned" is derived from the steel blue featliers on the head.

These birds are gregarious and move about both by day and night. As the sun is setting they may be heard giving their noisy cries, from which come the name "Quawk," while moving slowly, with deliberate wing-beats, in single file like troops.

Black-crowned night herons, like other night herons, remain hidden by day in some secluded piece of timber preening their feathers. Herons are wading birds, but are not very active, and seem contented in dry territory after satisfying their appetites with food, principally aquatic animals. Having favorite feeding-grounds, they often travel twenty or thirty miles to feed in the same marsh.

A bird lover discovered a heronry of these birds in a growth of coniferous trees in Kankakee County, Illinois. The nests were placed so close together that it was possible to inspect the contents of twenty-seven nests without descending to the ground, some trees containing as many as fifteen nests. 
Four to six light blue eggs are laid in a nest, usually composed of coarse twigs arranged in the nature of a platform. While in the Devil's Lake region of North Dakota, I encountered these lerons nesting in the treeless sections. The nests, resembling those of bitterns, were built in dense reeds and rushes bordering fresh-water lakes. Black-crowned night herons breed chiefly in the United States from the Atlantic across the continent to British Columbia. 


\section{CHAP'TER VII}

\section{MARSH BIRDS}

THE Crane family comprises eighteen species of large birds, of which three are North American. They are omnivorous feeders, eating frogs, mice, snakes, insects, and some regetable food found about marshes and plains. They migrate in flocks, but at other times are more solitary. Because of large size and few eggs laid, and persistent hunting, they are rapidly decreasing in numbers.

Fifteen species of Rails, Gallinules, and Coots inhabit North America. Rails and gallinules are not strictly gregarious. Coots, however, are found in flocks. Rails seek safety by ruming and secreting themselves, flying only when pressed when flight is short, as they quickly drop back to cover; yet in migration their flight is strong. Gallinules are strictly marsh birds; coots are aquatic, resembling ducks, but are distinguished by their white bill and lobed feet.

Phalaropes are found in the northern part of the Northern Hemisphere. They are peculiar in that the female is the larger and more brightly colored; the male does the wooing, constructs the nest, incubates the eggs, and cares for the young. Although marsh birds, they are web-footed and swim with the ease of a duck.

Arocets are usually found in flocks, feeding in shallow water. The bills are sensitive, enabling the bird to select its food even if water is muddy, as it swings the bill from 
side to side. Although it has long legs and bill, it possesses webbed feet and swims with ease.

\section{SANDHILL CRANE}

The Sandhill Crane ranges from Florida and Georgia northward through the Mississippi Valley to Manitoba, wintering in the Gulf States.

In America the cranes are threatened with extinction. Their conspicuous size and the fact that they are less prolific than most of our game birds account for the scarcity of this great wader. The sandhill crane is local in its breeding range. A number remain in the almost inaccessible swamps of Florida to nest; in all other states of the Union the bird is of rare occurrence, except as a migrant. One or two pairs have managed to run the gauntlet of the gunner and still retire to open marshes along the Kankakee River in northern Indiana. A few pairs spend the summer in remote sections of Minnesota and the Dakotas. Of late years, however, northwest Canada has afforded more places of refuge for the sandhill crane and its relatives, the whooping and little brown cranes.

Cranes are less aquatic than other wading birds. They feed largely upon dry ground, hence their food is often obtainable in cultivated sections, where the bird would no doubt thrive were it assured immunity by man, its worst enemy. The flesh of the sandhill crane is greatly esteemed among epicures, as it is not rank, like that of most large wading birds, due to difference in diet.

Their nest is a huge mass of grass or hay, arranged 


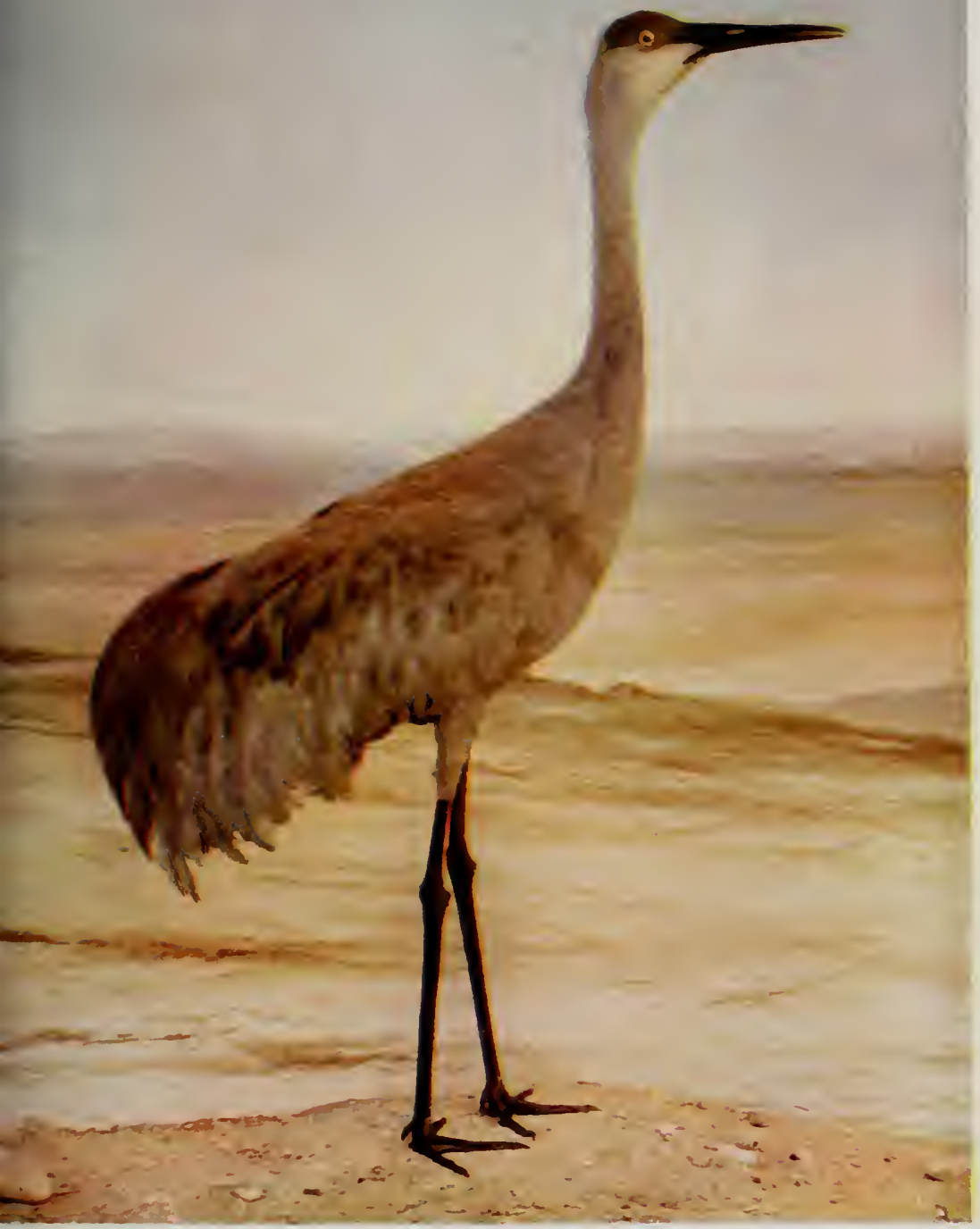





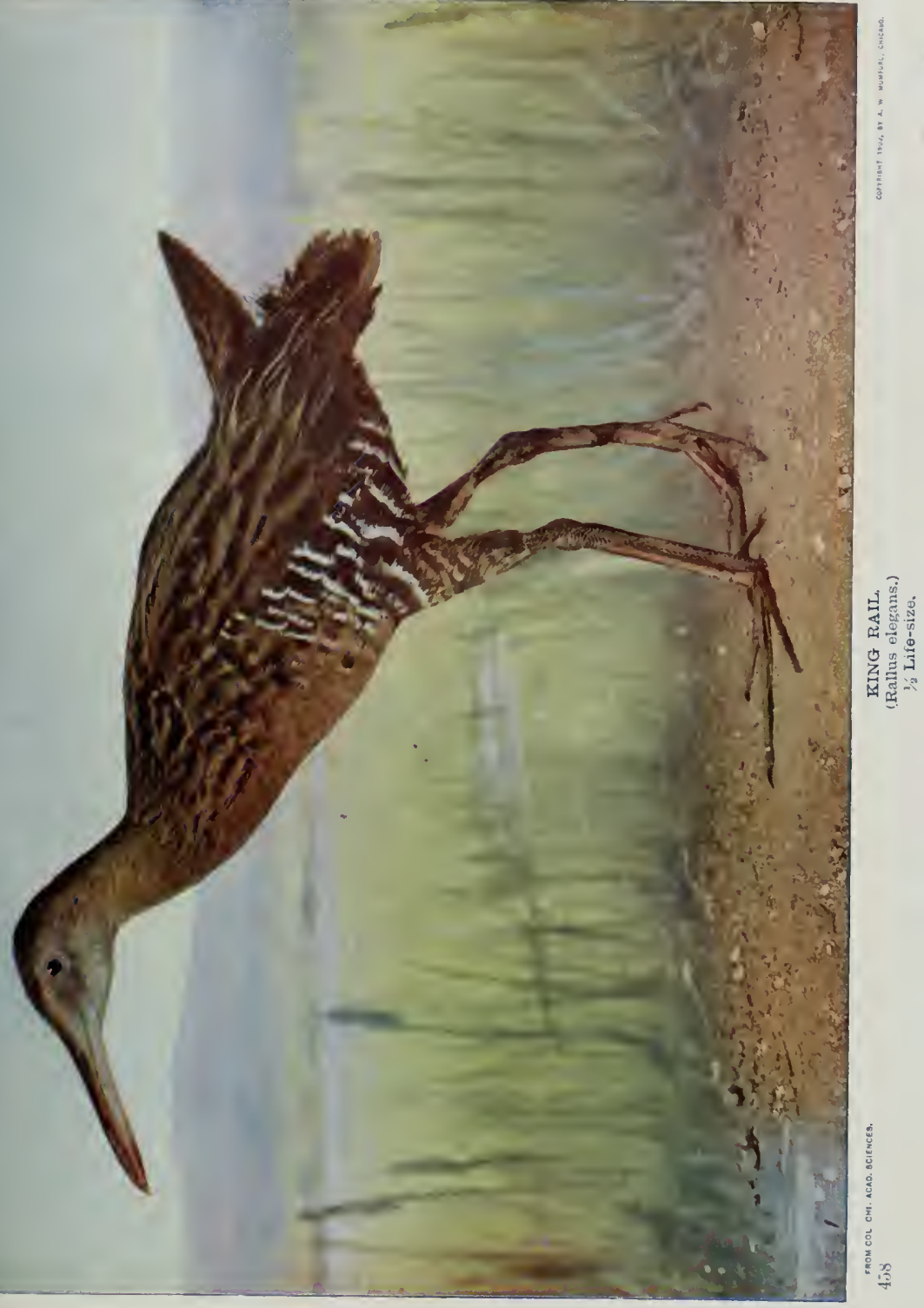





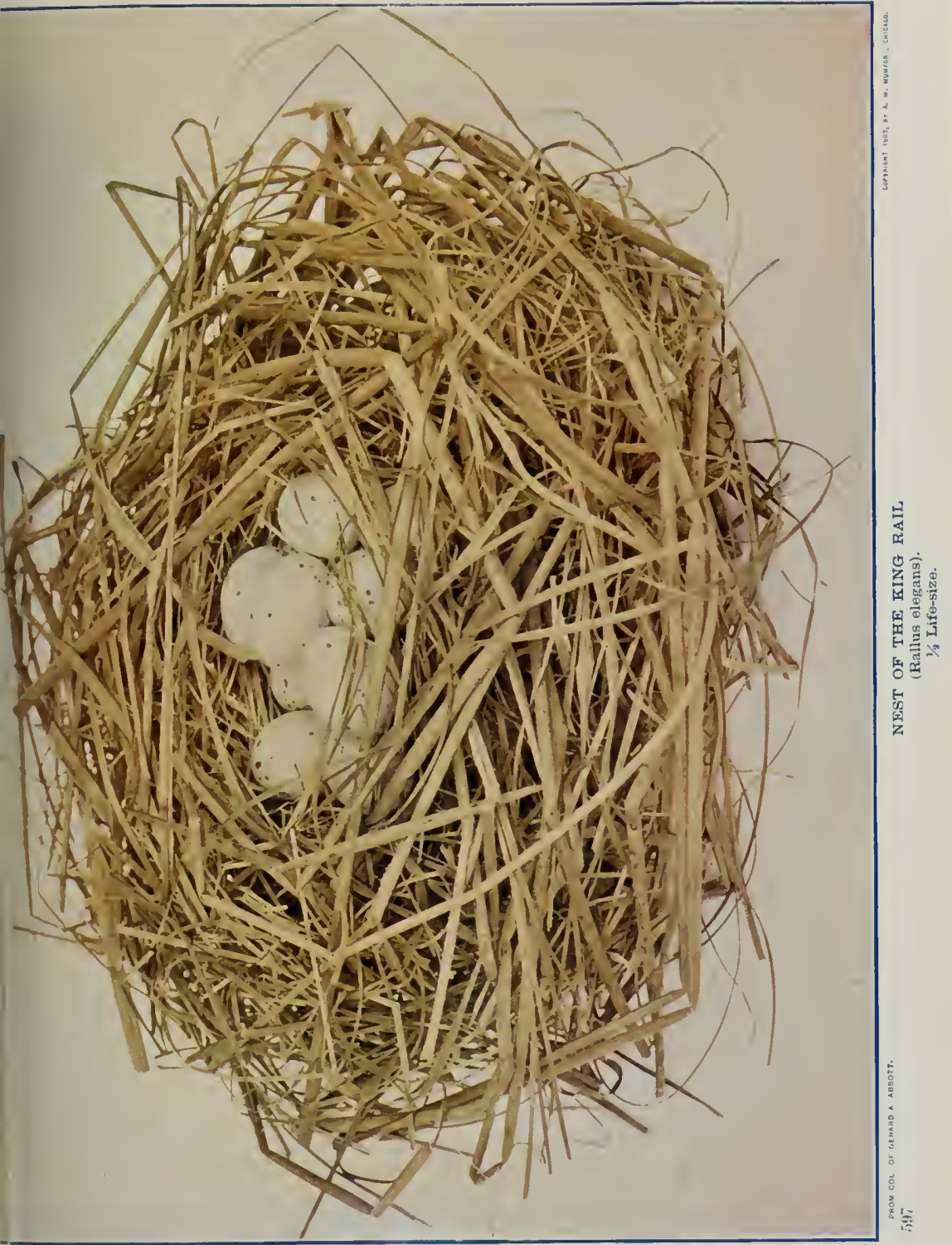



often in shallow water, but built so high as not to interfere with incubation. Only two buffy brown, blotched eggs are laid.

In April and May, during the mating and nesting season, the cranes give vent to their feelings of passion in a most hilarious manner. The males indulge in performances not unlike an Indian war dance, flapping the wings and jumping into the air, alternately landing on first one foot and then the other. During the excitement the females participate and the show continues until the birds cease from utter exhaustion. They also have a soaring, circling, croaking flight, at a great elevation. So loud is this croak that it may be heard after the birds have passed from sight.

\section{KING RAIL}

The King Rail, or Marsh Hen, breeds from northern Missouri to southern Connecticut, strays farther north, wintering in Virginia and Kentucky, south.

This largest of fresh-water rails inhabits the reedy margins of bayous, ponds, and inland marshes. East, south, and west of the Great Lakes region it is replaced by various forms of the clapper rail. The male and female are similar in plumage, while the young are covered with jet black down. The bodies of the rails are compressed, enabling the owner readily to pass through tangled vegetation, for which the feet and legs are remarkably well adapted, as with widespread toes they traverse the bogs and impenetrable swamps and quagmires with an unequaled agility, taking wing as the last resort. 
Rails are less aquatic than coots or gallinules, and, though not gregarious, are seldom found in isolated pairs. Frequently several varieties of rail occupy their respective nests within a few yards of each other, and, again, all three species will deposit their eggs in a single nest, which is usually that of the king rail, the largest of the genera.

No one should be surprised at the antics of this bird. A neighbor discovered one in the front room, after leaving the door ajar one morning. King rails have been observed about the barnyard in company with the poultry. On several moonlight nights, between the hours of eight and ten, in May and June, I lave heard and seen this droll-looking bird strolling about the streets of Chicago, perhaps one-half mile distant from the nearest marsl. It ventures upon the sidewalk and poses under the light of a street lamp, and suddenly becomes hilarious, calling, cackling, and creaking, its hoarse voice breaking the silence of the calm spring atmosphere, and then he vanishes as if by magic.

Ten eggs in the writer's collection were taken June 10, 1908, at Worth, Cook County, Illinois. The grass nest was placed at the base of a clump of grass, the top of which was naturally woven so as to form a canopy over the eggs. The nests are usually placed in shallow water, but this particular nest was on dry land close to a pond.

\section{THE CLAPPER RAIL*}

This bird, sometimes called the salt-water marsh hen, is found in great abundance in the salt marshes of the Atlantic coast from New Jersey southward. It breeds in profusion 



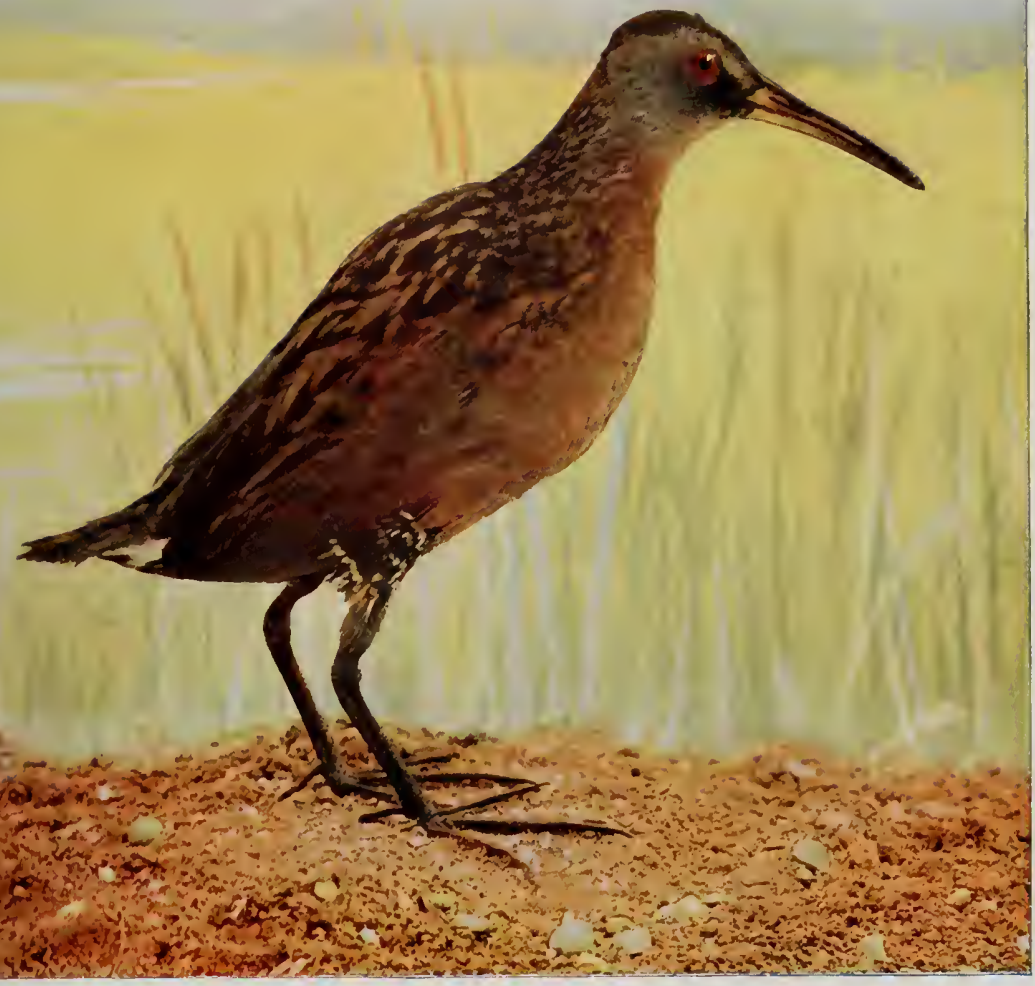



in the marshes from the Carolinas to Florida, and has lately been found breeding on the coast of Louisiana, on the Gulf of Mexico. The clapper rail arrives on the southeastern coast of New Jersey about the last of April, its presence being made known by harsh cries at early dawn and at sunset. Nest-building is commenced in the latter part of May, and by the first of June the full complement of eggs is laid, ranging, says Davie, from six to nine or ten in number, thirteen being the probable limit. Farther south the bird is known to lay as many as fifteen. On Cobb's Island, Virginia, the clapper breeds in great numbers, carefully concealing the nest in high grass. The color of the eggs is pale buffy-yellow, dotted and spotted with reddish-brown and pale lilac, with an average size of $1.72 \times 1.20$, but there is a great variation in this respect in a large series.

At the nesting season the rails are the noisiest of birds; their long, rolling cry is taken up and repeated by each member of the community. The thin bodies of the birds often measure no more than an inch and a quarter through the breast. "As thin as a rail" is a well-founded, illustrative expression.

The rail can swim fairly well, but not fast. Its wings are short but useful, and it is so swift-footed that dogs chase it in vain.

\section{THE VIRGINIA RAIL*}

This miniature of king rail is found throughout the whole of temperate North America, as far as the British provinces, south to Guatemala and Cuba, and winters almost to the northern limit of its range. Other names 
of the species are: Lesser clapper rail, little red rail, and fresh-water mud hen. The male and female are like small king rails, are streaked with dark brown and yellowisholive above, have reddish-chestnut wing coverts, are plain brown on top of head and back of neck, have a white eyebrow, white throat, breast and sides bright rufous; the flanks, wing linings and under tail covers are broadly barred with dark brown and white; eyes red.

The name of this rail is not as appropriate today as it was when Virginia included nearly all of the territory east of the Mississippi. It is not a local bird, but nests from New York, Ohio, and Illinois northward. Short of wing, with a feeble, fluttering flight when flushed from the marsh, into which it quickly drops again, as if incapable of going farther, it is said this small bird can nevertheless migrate immense distances. One small straggler from a flock going southward, according to Neltje Blanchan, fell exhausted on the deck of a vessel off the Long Island coast, nearly a hundred miles at sea.

The rail frequents marshes and boggy swamps. The nest is built in a tuft of weeds or grasses close to the water, is compact, and slightly hollowed. 'The eggs are cream or buff, sparsely spotted with reddish-brown and obscure lilac, from 1.20 to 1.28 inches long to .90 to .93 broad. The number in a set varies from six to twelve. The eggs are hatched in June.

The Virginia rail is almost exclusively a fresh-water bird. It is not averse to salt water, but even near the sea it is likely to find out those spots in the bay where freshwater springs bubble up rather than the brackish. 


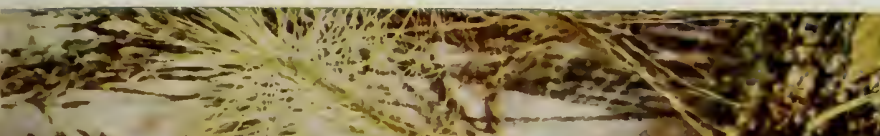

son

$580^{5}-500$

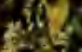
povare

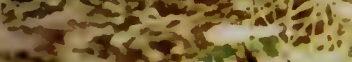

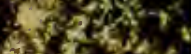
$4 x^{2}=3 x+2$ $x^{2}-5,1$

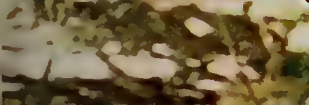

(x)

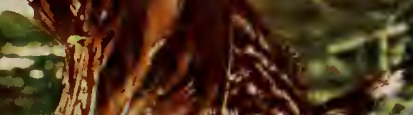

$4.50,130$

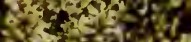

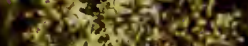

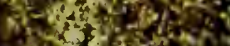
wors 5 at and

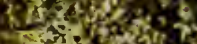
s.

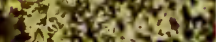





\section{SORA RAIL}

The Carolina, or Sora, Rail is the most plentiful of the family inhabiting at large the marshes and swamps of the East and Middle West through United States and Canada to Hudson Bay, wintering from the Gulf States to northern South America. IVest of Missouri, Iowa, and Dakota they diminish in numbers and occur erratically. In general structure and appearance the sora is very much like the gallinule. The bill is stout, the toes extremely long, and, though not webbed or lobed, the birds swim readily. The note is a high, rolling whinny, uttered in the ascending scale, which note is taken up by other birds in the marsh and carried for miles.

They frequently inhabit more inaccessible swamps and marshes than the other rails, though the sora is less timid. They fly awkwardly, with dangling leg, over the marsh, soon dropping into cover. Frequently a sora permits capture on foot rather than expose itself to a gunner by attempting flight. These birds, like the marsh wrens which inhabit the same cover, construct sham nests. They are sociable creatures, as two females sometimes deposit their eggs in the same nest.

In the Great Lakes region this bird arrives about the middle of April, and the duties of incubation commence as soon as the first egg is laid. The nests are loosely constructed of bulrushes and grass, well concealed in a clump of rank vegetation. Like the gallinule, the birds have a habit of constructing a little path or runway leading from the nest to the water's edge. 


\section{YELLOW RAIL}

The Yellow Rail inhabits both eastern and western North America from the Atlantic to the Pacific, ranging north to Hudson Bay and south in winter to the Gulf of Mexico. None of our other rails has a more extensive range. Comparatively little is known of this species because of its retiring habits and small size. They occur in many localities where their presence is not suspected. It is almost impossible to flush the little birds, and unless one is acquainted with their haunts or can lunt them with a good bird dog, little opportunity is afforded the observer to form an acquaintance with it. Grassy tracts along coulees and prairie marshes are the haunts of the yellow crake, which avoids cattails and sluggish water more than do the other rails.

One observer was fortunate in discovering a little colony of these birds in North Dakota, and by diligent watching located several pairs and ultimately discovered their nests, which were concealed in thick clumps of grass in open, marshy places. Until these nests were located the eggs of the yellow rail were practically unknown to science. The six or more eggs are among the most beautiful found in North America; the background is a rich cream color, having a cluster of minute purple and brown specks about the large end. The nest is a loosely constructed affair of grass and weed stems, placed upon the ground within the protecting shadows of bunches of sedges or reeds, often being placed in a tussock of grasses surrounded by water. 


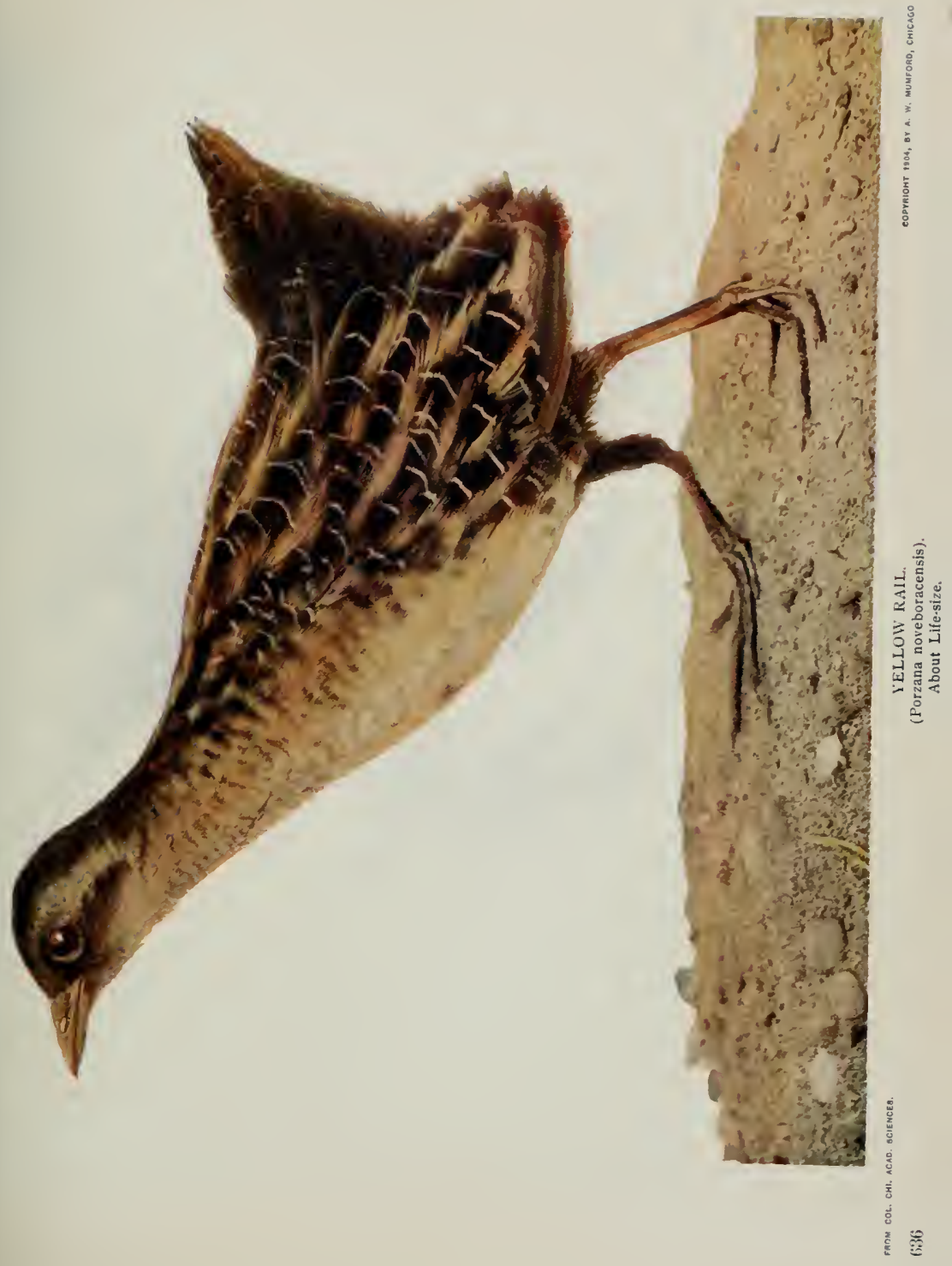






\section{PURPLE GALLINULE}

The range of the Purple Gallinule is tropical America to southern Illinois, wintering from Florida southward.

This brilliant bird is common to the Southern States. It is generally associated with the Florida gallinules, but is marked by more brilliant plumage.

"It has little of the aspect of a gallinule, but stands higher, and has its legs more forward. As it walks, the neck is alternately bridled up or thrown forward, and its short black and white tail is changed from a semi-erect to a perpendicular position, with a flirting motion. As this bird walks over the tangled leaves and stems of aquatic plants resting on the surface of the water it moves with great deliberation, frequently standing still and looking leisurely about. Ever on the lookout for any danger that may menace it, at the least noise it hides among the rushes. Only when its place of concealment is invaded is flight attempted, when progress in the air is heavy and not well sustained. Its voice is loud and strong, but has in it nothing remarkable.

"Worms, mollusks, and the fruit of aquatic plants are its food. It gathers seeds and carries them to its beak with its claws, and it also makes use of its claws in clinging to the rushes, where the water is very deep." (Brewer.)

The nest is a platform of reed stalks built in rushes over water or in marshes; eight to ten eggs are laid. The eggs are spotted and smooth shelled, and the nestlings when first hatched are clad in dark-colored brown. 


\section{FLORIDA GALLINULE}

The Florida Gallinule, or Rice-hen, has a more extensive range than the name would indicate. While many of these birds remain in the Atlantic and Gulf States during the summer, the bird is found as far north as Massachusetts and Maine and westward along the Canadian border to Minnesota. In the Middle States west of the Mississippi River their appearance is somewhat erratic, though they abound in certain localities in Ohio, Michigan, Indiana, and Illinois. The Calumet region, near Chicago, is a favorite summer home. They show a preference for stagnant water surrounded by cattails and bulrushes.

Gallinules sometimes appear as a "connecting link" between rails and coots. I have observed the king, sora, and Virginia rails, with the coot, nesting near to gallinules, and noted a striking resemblance between the gallinules and some rails; for instance, the sora, with its compressed body and widespread toes, always reminds me of a small gallinule. Both swim about among the rushes, and I noticed that one sora deposited her eggs in a gallinule's nest.

Like the coot, the gallinule often breeds in colonies. Some nests are built in clumps of dead rushes and float upon the water in a manner similar to that of a grebe. Other nests are suspended a foot or two above the water, and are handsomely woven with blades of grass and rushes. When the nest is completed a pathway is constructed of the same material that is used in building the nest proper, and forms a runway extending from the nest into the water. This is a 


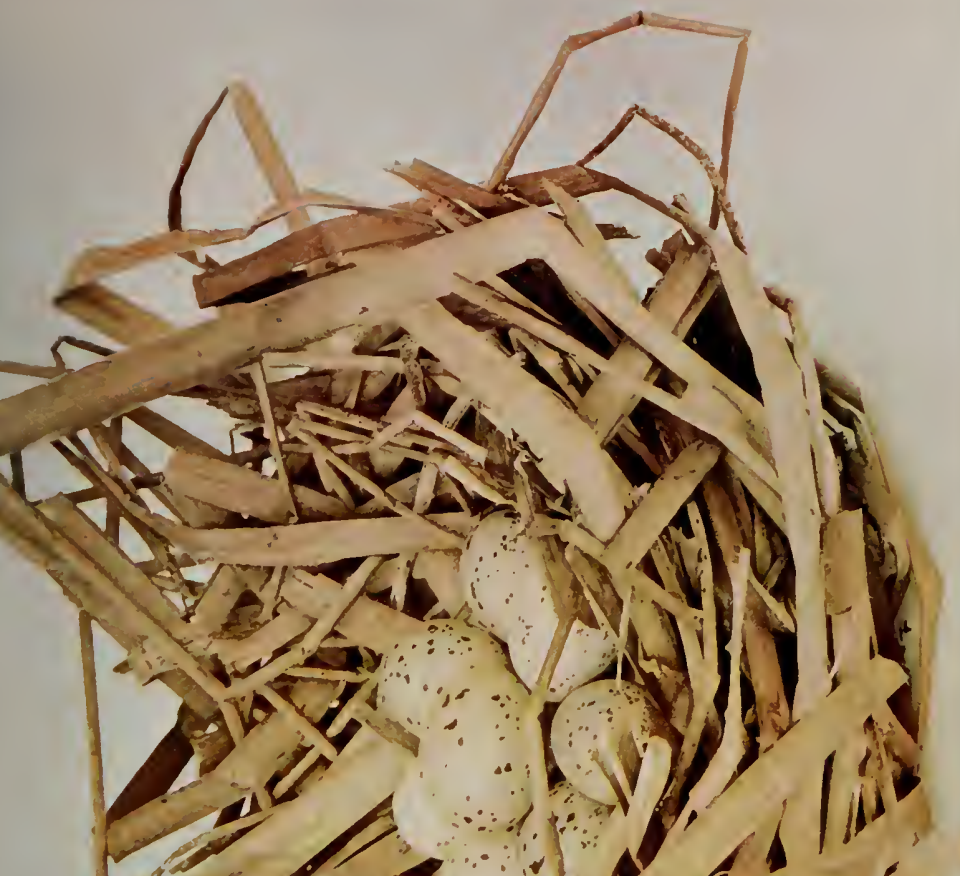



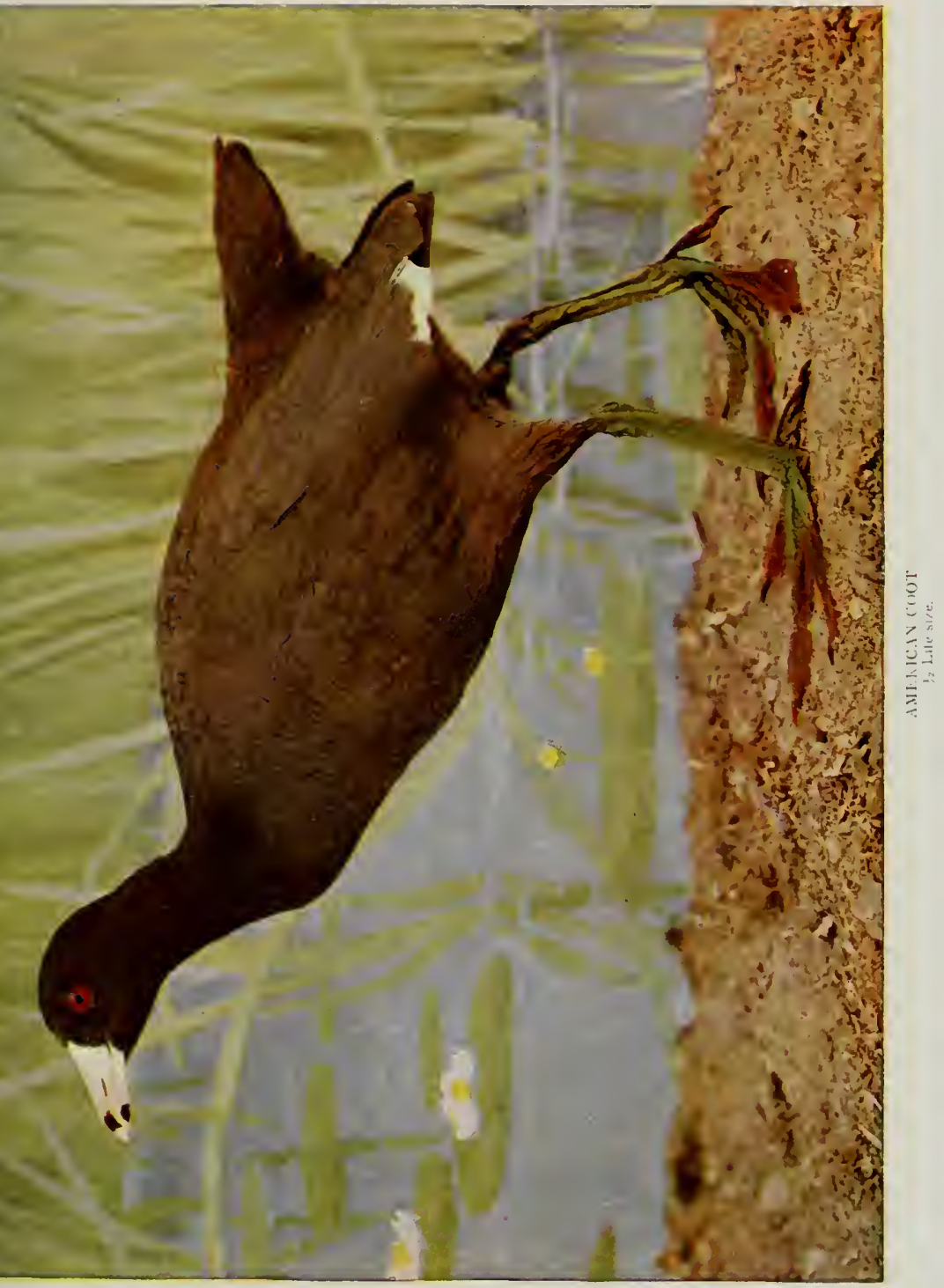



characteristic which immediately distinguishes a gallinule's nest from that of a coot.

The number of eggs range from seven to fourteen. I have eleven eggs taken May 28, 1902, at Worth, Cook County, Illinois. The nest was built of sedges and rushes fastened in a clump of same over water three feet deep, on the border of a pond.

\section{COOT}

The Coot, or Mud Hen, ranges throughout North America to Alaska, being rare on the Atlantic coast but abundant about marshes in the Mississippi Valley; it ranges south in winter to the Gulf States.

The coot is one of the connecting links between waders and swimmers, partaking of the habits of our rails and gallinules, but is more aquatic than either. 'The feet, like those of the grebe, are lobed, enabling the bird to walk on floating vegetation and over soft soil with great ease and to swim more readily among reeds, etc. This bird is not really a game bird, but is legally regarded as such. It fills the bag of many would-be sportsmen who are unable to shoot ducks or more palatable game. Coots are fairly abundant throughout the United States and southern Canada. Orer the northern tier of states into Ontario and Manitoba the mud hen summers in great numbers.

This is our only marsh bird with a white bill, thus serving as an infallible field mark. When swimming the birds accompany each stroke of the foot with a nodding of the head similar to the movement on land of our semi-domesticated dove or pigeon. 
The nests are beautifully constructed of dead rushes, and especially grass. These receptacles are deep and are cleverly woven to living vegetation over water from six to thirty inches deep. The nests rise and fall with the water, so that the birds have no fear of floods.

The eggs have a decided clay color, dotted all over with minute specks of dark brown or black.

\section{THE NORTHERN PHALAROPE*}

The Northern Phalarope has a wide range, extending throughout the northern portion of the Northern Hemisphere and in winter reaching the tropics. It breeds only in Arctic latitudes. It is a bird of the ocean and seldom is observed inland, except as a rare migrant early in May or in October. Then it "frequents slow streams or marshy pools."

This phalarope belongs to the shore birds and to a family that contains but three known species. Tro of these are sea birds. The other, Wilson's phalarope, is an inhabitant of the interior of North America. Their feet are webbed, and usually two marine forms, or sea snipe, as they are sometimes called, migrate in flocks far from land.

It is not an exaggeration to say that it is one of the most beautiful of our aquatic birds. All its motions are graceful. It possesses a quiet dignity and elegance while swimming in search of food, which it frequently obtains by thrusting its bill into the water. In this manner it obtains a large number of marine animals and flies that may be on the surface of the water. When on the shore it may be seen wading and swimming in ponds near the coast. 


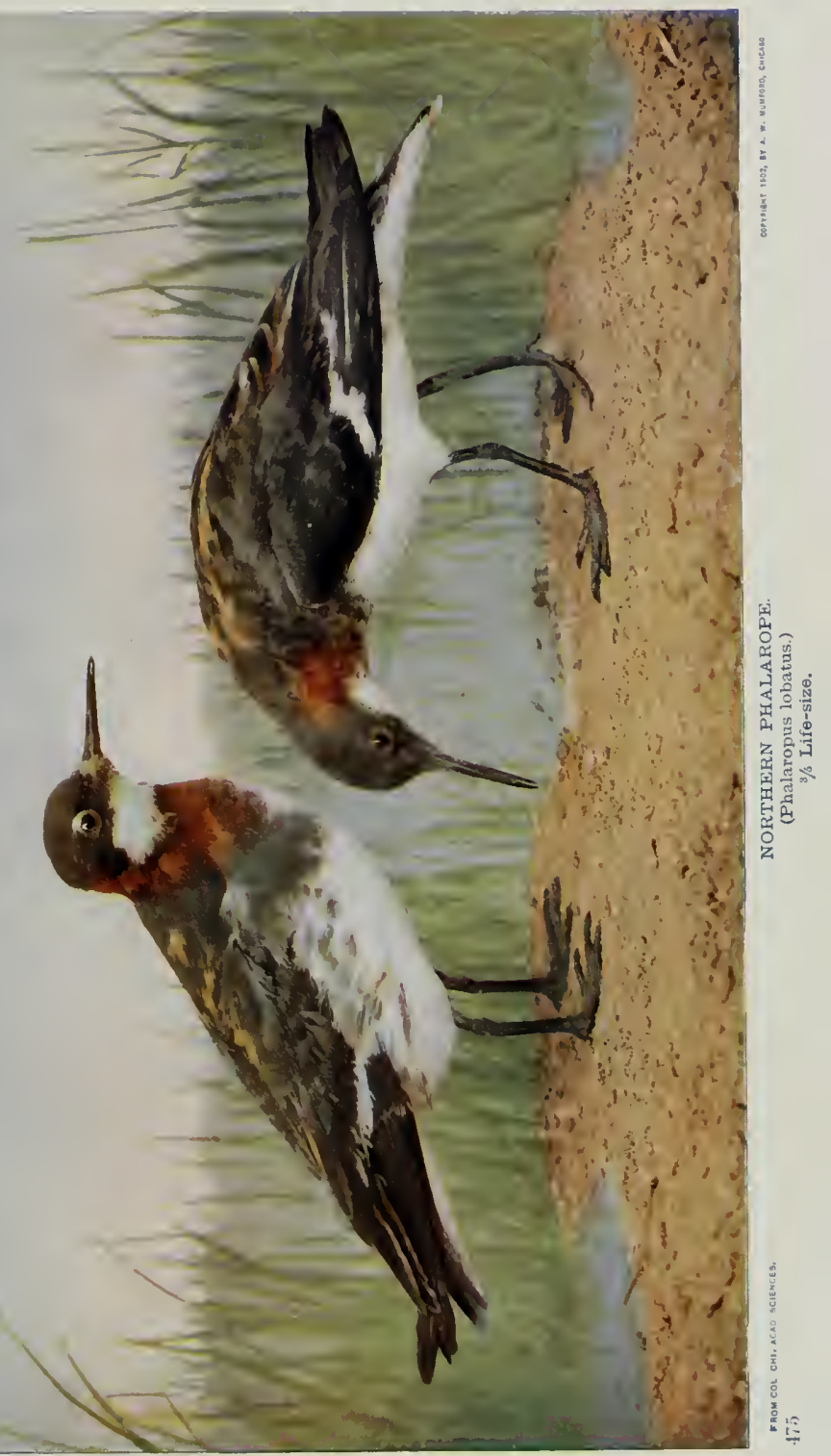





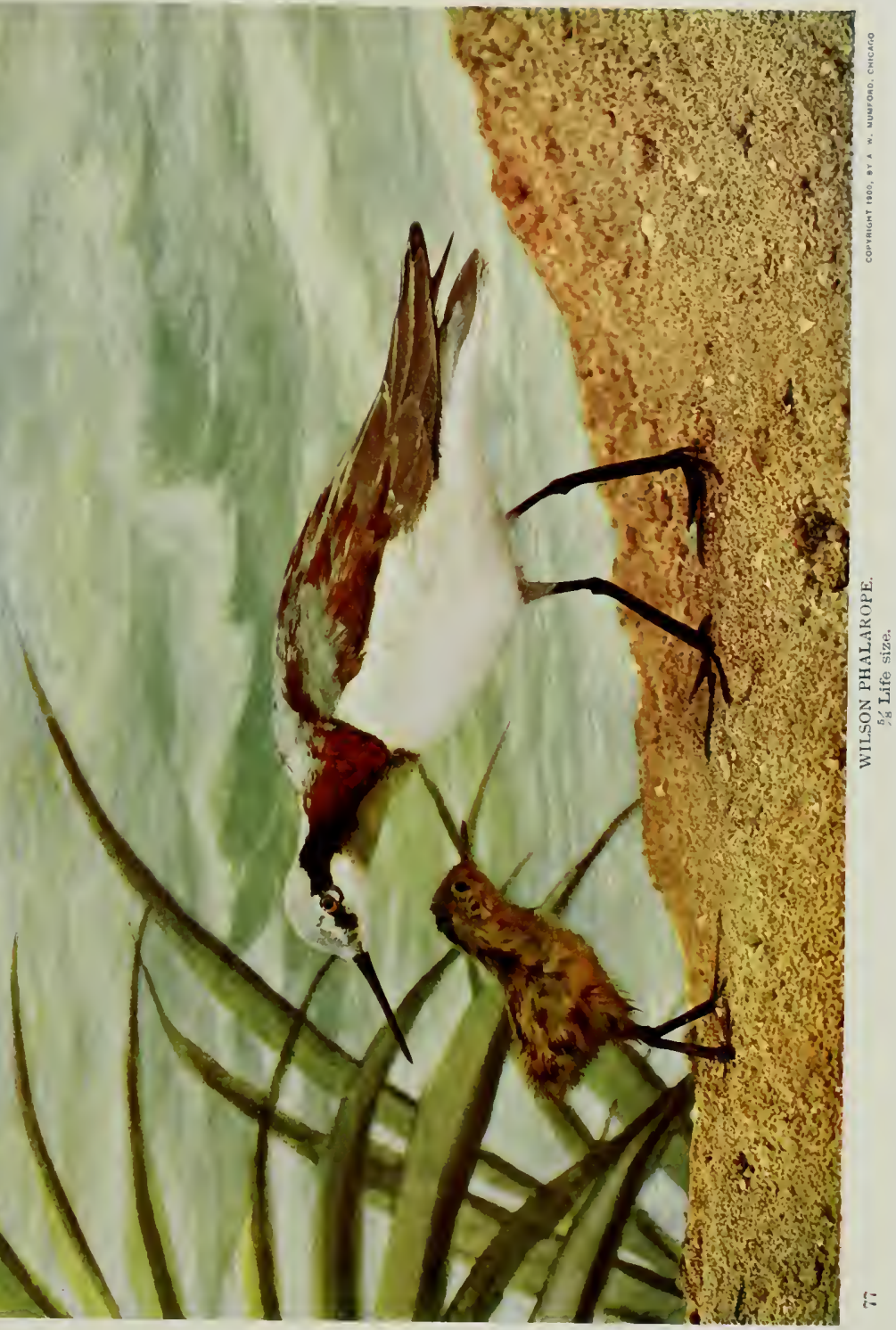


Its habits at the mating season are most interesting. "As the season comes on when the flanes of love mount high, the dull-colored male moves about the pool, apparently heedless of the surrounding fair ones. Such stoical indifference usually appears too much for the feelings of some of the fair ones to bear. A female coyly glides close to him and bows her head in pretty submissiveness, but he turns away, pecks at a bit of food, and moves off; she follows and he quickens his speed, but in vain; he is her choice."

Then, after the four dark and heavily marked eggs are laid, the "captive male is introduced to new duties, and spends half his time on the eggs, while the female keeps about the pool close by."

Their nests, at best, consist of only a few blades of grass and fragments of moss laid loosely together. Often the eggs are laid in some convenient hollow, with no bedding whatever except that which happened to lodge there.

\section{IVILSON'S PHALAROPE}

Of the three Phalaropes inhabiting North America this is the only one peculiar to this continent. Their range extends across the United States and southern Canada from the Atlantic to the Pacific, much more common in the interior. They breed from northern Illinois and Utah northward, wintering south to Brazil and Patagonia. An extremely interesting species, it feeds principally in shallow water, either by wading or swimming. The feathers on the breast are long and compact, and the birds are just as immune from the water as are our more aquatic ducks and 
gulls. One of the most beautiful sights in the prairie regions from northern Illinois through Minnesota and North Dakota is a number of these graceful creatures floating buoyantly in a shallow pool.

The females are by far the handsomer, slightly larger than their mates and handsomely though delicately colored. While looking for the nest the bird student is not deceived by these reversed conditions, so characteristic of the species. Naturally, the dull-colored bird among all other American species, where a difference in plumage is noticeable, assumes the household duties. 'Therefore, the uneasiness of the little, inconspicuous male phalarope conveys the idea that we are trespassing upon the breeding-grounds. The handsome female deposits her eggs in a nest which has been constructed by her mate. It is composed of dead stems placed in a hollow underneath a tuft of grass, or at times a large, bulky structure is arranged on top of the damp soil just above high-water mark.

The female, after laying the eggs, usually joins others of her sex, and they move leisurely about the country, feeding on mud flats or wet meadows, until they become extremely fat. They do not join the males or young until time for the southward migrations in September.

The note of the phalarope is a beautiful little "honk" with a nasal twang to it. I discovered a small colony, comprising less than a dozen birds, early in May, 1911. They were occupying a slough near a body of fresh water. It was necessary to climb a fence before entering the nestinggrounds. This was a signal for the little colony to rise simultaneously and fly back and forth over the marsh with 


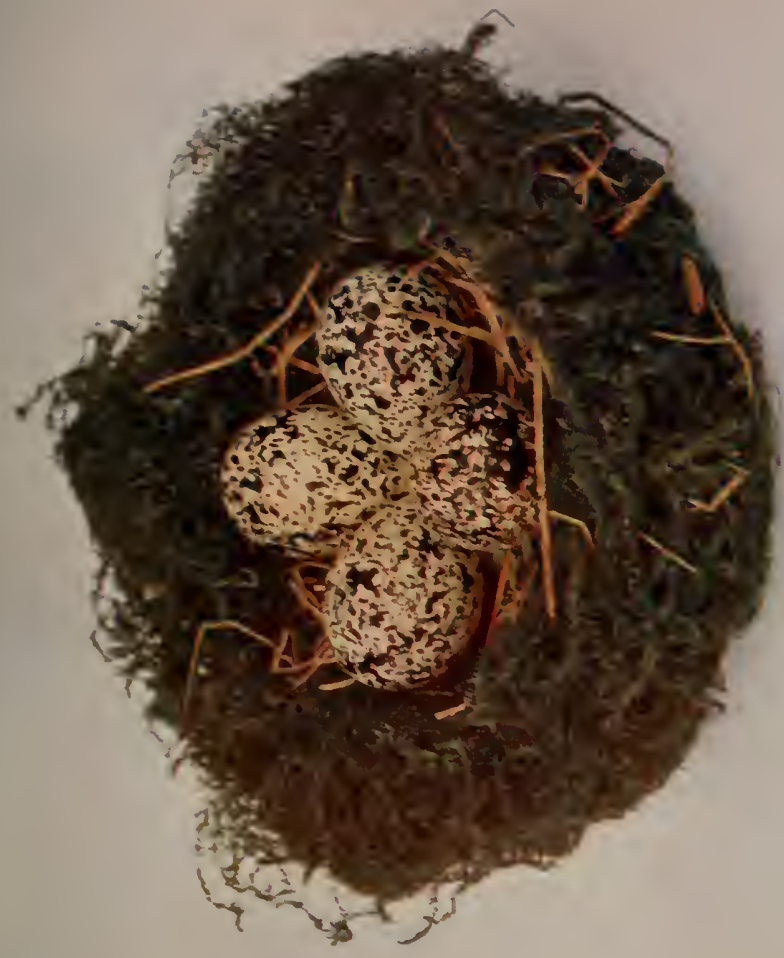

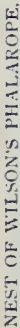




slow, deliberate wing-beats. When directly overhead the males would poise momentarily and utter soft, mellow notes of protest. Each note was emitted apparently with some effort, causing the bird to check its flight and throw the head backward.

The only way I succeeded in locating the nests was by watching the males through my field glasses from a distance. Presently each poised as a black tern is known to do just over the nest. Frequently the first setting of the phalarope is destroyed by an overflow. A second setting is then laid, consisting usually of only two instead of four eggs.

The eggs are clay-colored, decidedly and handsomely blotched with umber brown and black, particularly at the larger end. 'The young when hatched are covered with a coat of chestnut brown, and are led about by the male for about two weeks before they can fly.

Wilson's phalarope is local in its habits and is becoming rare in the Great Lakes region. It seems hard to realize the reports furnished by Mr. Nelson, the first ornithologist of record for northern Indiana and Illinois. He reports in 1876 that the little phalarope was then the commonest of our small waders, outnumbering even the spotted sandpiper and killdeer.

\section{AVOCET}

The Avocet ranges throughout temperate North America, wintering along the Gulf Coast and southward.

The avocet is outwardly unlike other American birds; the bill is recurved, and, though a shore bird, the toes are 
webbed. The bill is so soft and pliable that one may wind it several times about the finger. While wading rapidly, and with bill touching bottom, the bird swings this bill from side to side as a mower a scythe, thus enabling the bird to feed in muddy water. These birds grow less common from the Mississippi to the Atlantic. Their favorite haunts are small inland lakes in the prairie districts from Colorado and Nebraska northward into Canada, breeding in numbers about the alkali waters of the Salt Lake region.

By some observer's their call is described as the "bark" of the arocet. They wade into the water up to their breasts, and, if progress on foot is difficult, they swim buoyantly about after the manner of our phalaropes.

The plumage has a beautiful pinkish cast about the head, neck, and breast. Individual birds differ considerably in plumage and size of bill. The wings show less development than those of most waders.

Probably no other wader is more closely feathered underneath than this species. The covering resembles that of our gulls, which explains the bird's ability to alight in deep water and swim about without wetting the flesh.

Four buffy brown, black-spotted eggs are deposited in a little depression close to the water's edge. 'The birds are not close sitters, but manifest an uneasiness at the approach of man.

\section{THE BLACK-NECKED STILT*}

Stilt would be a peculiarly appropriate name for this bird, with its excessively long legs, were it less graceful and dignified in its walk, moving on land with easy and meas- 


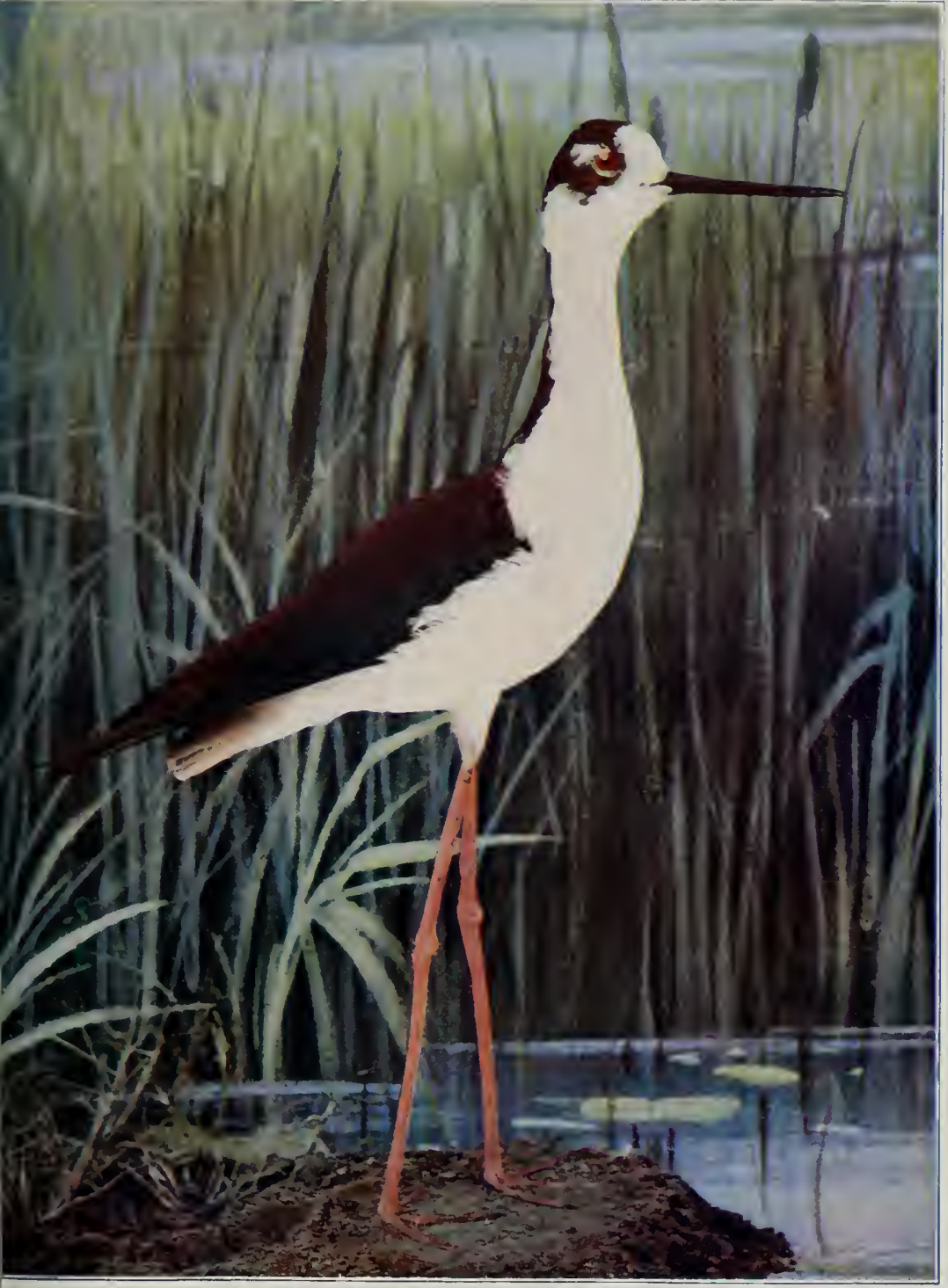



ured tread, not in a "tremulous manner," says Colonel Goss, as stated by some writers.

The stilt is an inhabitant of temperate North America from New Brunswick, Maine, Minnesota, and Oregon southward; south in winter to Peru, Brazil, and West Indies.

This slender wader inhabits the shores of bays, ponds, and swales where scantily covered with short grasses. It swims buoyantly and gracefully, and on land runs swiftly, with partially raised wings, readily tacking or stopping in its chase after insect life. Its flight, says Goss, is not very swift, but strong and steady, with sweeping strokes, legs fully extended, and head partially drawn back, after the manner of the avocet, and, like the latter, will of ten meet one a long distance from its nest, scolding and threatening.

The food of the Black-necked Stilt consists of insects, minute shellfish, and larvæ, and various small forms of life. The birds are social, usually living and breeding in small flocks.

The nests of these birds - when placed on dry, sandy land - are slight depressions worked out to fit the body; on wet lands they are upon bunches or masses of vegetation. Eggs, three or four, buff to brownish-olive, irregularly but rather thickly splashed and spotted with blackish brown. 


\section{CHAP'TER VIII}

\section{SHORE BIRDS}

SNipes and Sandpipers are generally distributed throughout the world, breeding particularly in the northern part of the Northern Hemisphere, forty-five species being found in North America. They are shore birds and are seldom found far from water. While gregarious in migration, they do not nest in colonies. Their long bills, some of which are sensitive, are used as probes, while the woodcock moves the upper mandible by curving the point downward, the better to extract worms from the earth. While not song birds, some of them have a short musical note at nesting times. Although small, they are favorite game birds.

Eight species of plover are found in North America. They have a general resemblance to the true snipes, but have shorter bills and are not fitted for probing, as they obtain food from the surface of the ground. In feeding habits some plovers resemble the grouse. All shore birds are powerful fliers and perform extensive migrations. They possess pleasing call notes or whistles. Economically the group is useful, both because they are game birds and because of the nature of their food.

Turnstones are of the family Aphrizide. They are a small family consisting of only three species, all of which are found in North America. They are small, plover-like, sea coast birds. They prefer the outer beaches. 


\section{WOODCOCK}

The Woodcock ranges throughout eastern North America, north to Labrador, breeding throughout most of the range, wintering from southern Illinois and Virginia southward.

The woodcock is a delight to the sportsman. When the drizzle has partly taken the frost out of the ground and we are experiencing twelve hours of daylight, the woodcock returns to the Mississippi Valley and the Great Lakes region, migrating by night. Those who know how and where to look for him are conscious of his presence when they visit the willow patches along lakesides or tramp through the hazel, which leads down to a springy spot. In these places the woodcock, or "owl among snipe," may be found probing the soil with his long, sensitive, flexible bill. $\mathrm{He}$ feels the contact with a juicy worm, and cleverly moves the upper mandible, thus extracting the morsel from the soil. The eyes are placed far back on the head, giving the bird great visionary power while probing.

Woodcocks are gluttons, consuming twice their own weight in twenty-four hours. Another habit is that of beating the earth with their feet, sounding like the patter of rain. This noise brings the earth worms to the surface, where they are captured.

The song-flight of the woodcock begins shortly after his arrival from the South and may be heard well into the warm summer nights of June, when the bogs are so infested with mosquitoes as to make life unbearable. The proper time to 
$0^{7}$

101) 1

No 10

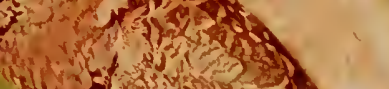

$4 t^{2}$

w.

(Ix) 3

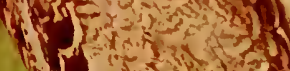

c. 30

$y, y-2$

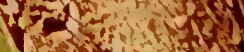

4

ath 1 .

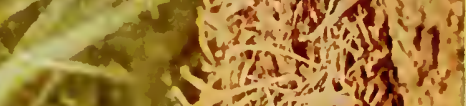

a.

10. 50

4) (4)

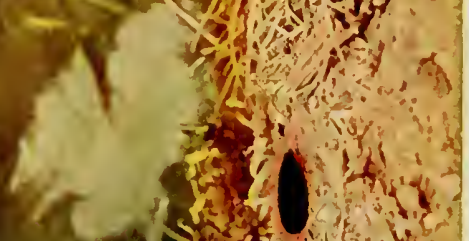

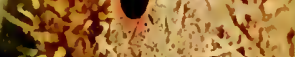
sel

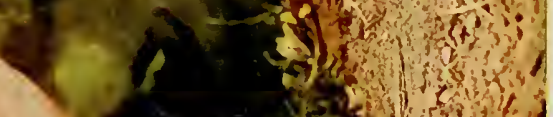

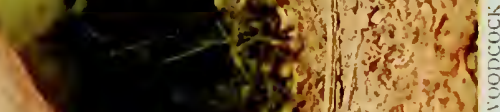

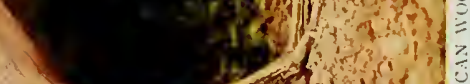





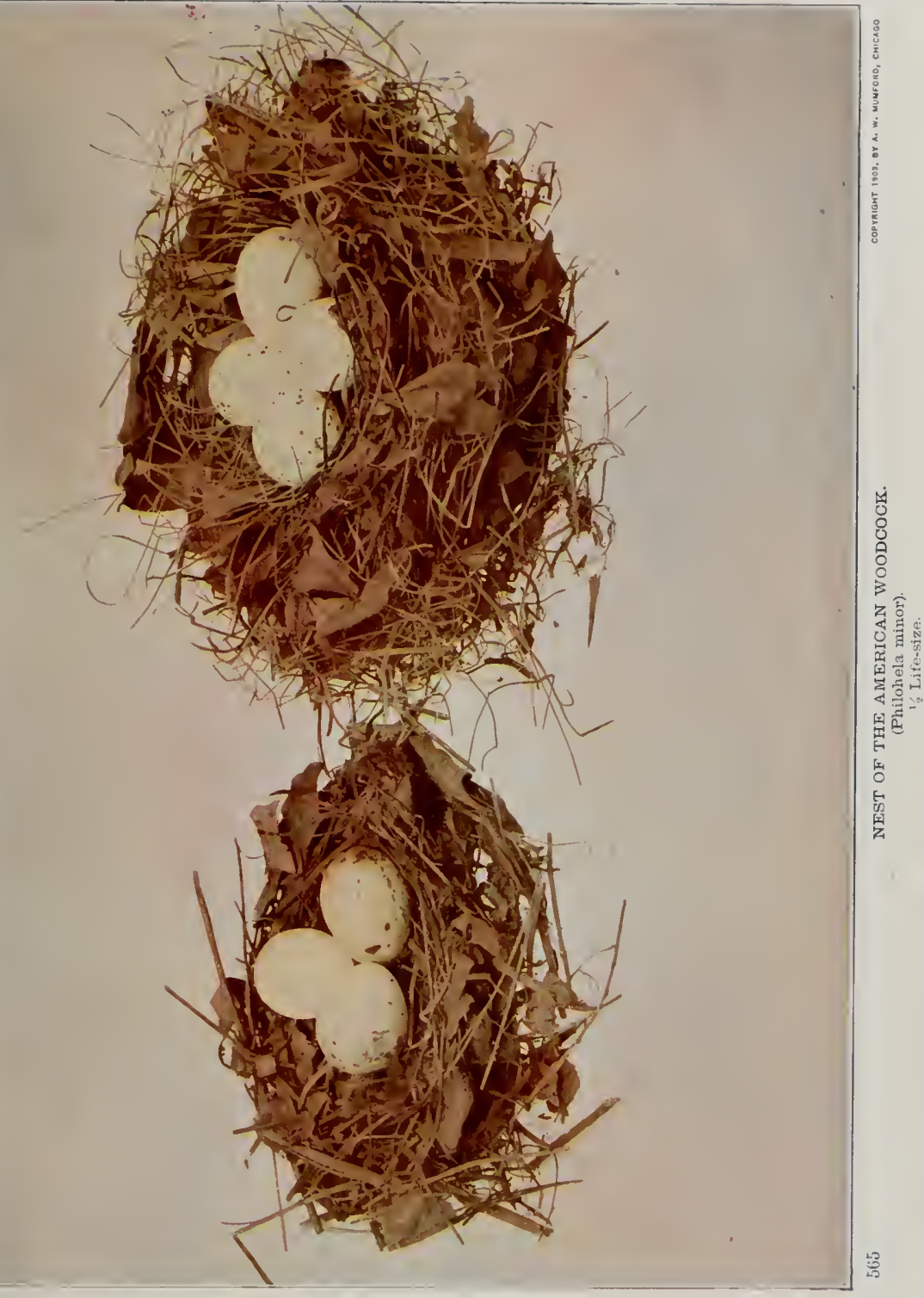



see the woodcock perform is during the cool nights of April when the birds are brceding.

I visit the moist places immediately after sunset, where during the daytime I have flushed woodcock or observed perforations among the soft leaves. Presently a short nasal call comes from the underbrush. It is suggestive of the nighthawk's call. After locating the bush under which the "speaking" takes place, there is a rustle of wings and a bird rises in circles. The wings beat rapidly, but the flight seems slow and laborious, as with legs dangling and tail spread, the creature presents an ungainly appearance. During the ascent a continuous warble seems to indicate that the object which we see in the dim twilight is in a fit of ecstasy. Scarcely can we attribute this melodious outpour to such a droll-looking bird as the woodcock. The "songster" has reaclied a height of several hundred feet, and the liquid notes become more intense, until the music suddenly ceases, and the bird darts obliquely to the ground, alighting within a few feet from where he arose. The "speaking" is resumed, and in about sixty seconds another flight is made.

The three outer primaries, or quill feathers, of the woodcock's wings are shorter than the others. These undeveloped primaries are turned edgewise during flight, producing a decided whistle, which is often the first intimation we have of a woodcock's presence.

Woodcocks are active during cloudy days, venturing forth to feed upon the earthworms then on or near the surface. In undisturbed localities they do not flush until one is within a few feet of them, when they suddenly spring into the air, rising perpendicularly to a leight of ten feet, then 

see the woodcock perform is during the cool nights of April when the birds are brceding.

I visit the moist places immediately after sunset, where during the daytime I have flushed woodcock or observed perforations among the soft leaves. Presently a short nasal call comes from the underbrush. It is suggestive of the nighthawk's call. After locating the bush under which the "speaking" takes place, there is a rustle of wings and a bird rises in circles. The wings beat rapidly, but the flight seems slow and laborious, as with legs dangling and tail spread, the creature presents an ungainly appearance. During the ascent a continuous warble seems to indicate that the object which we see in the dim twilight is in a fit of ecstasy. Scarcely can we attribute this melodious outpour to such a droll-looking bird as the woodcock. The "songster" has reached a height of several hundred feet, and the liquid notes become more intense, until the music suddenly ceases, and the bird darts obliquely to the ground, alighting within a few feet from where he arose. The "speaking" is resumed, and in about sixty seconds another flight is made.

The three outer primaries, or quill feathers, of the woodcock's wings are shorter than the others. These undeveloped primaries are turned edgewise during flight, producing a decided whistle, which is often the first intimation we have of a woodcock's presence.

Woodcocks are active during cloudy days, venturing forth to feed upon the eartliworms then on or near the surface. In undisturbed localities they do not flush until one is within a few feet of them, when they suddenly spring into the air, rising perpendicularly to a height of ten feet, then 
flying rapidly away in a zigzag course, suddenly dropping back into cover.

Various tints in the plumage harmonize remarkably with the brush, grass, and leaves when the woodcock is on her nest. A soft, leafy hollow in the earth at the base of a shrub or under a fallen bush is used for nesting purposes. While the bird is laying she cleverly covers her eggs with leaves, commencing incubation when the fourth and last egg is laid.

Sitting woodcocks exhibit so much confidence in their protective coloration that $I$ have frequently removed the parent from the nest with my hand. I have watched them for hours, and have yet to see a sitting bird show uneasiness until I am within two feet of the nest, unless her winking is too quick for human eye; she is able to suppress even that. The male is usually found near the incubating bird.

Often the country is covered by a snowfall in April, when the woodcock becomes wary and vacates the nest at the least indication of danger. This clearly illustrates that she realizes protective coloration has ceased while the earth is clothed in white.

The four eggs are creamy or light brown, spotted and blotched with various shades of brown and lilac. Incubation continues three weeks, and the young leave the nest as soon as hatched to be piloted about through the underbrush.

\section{WILSON SNIPE}

This famous game bird, known also as jacksnipe, English snipe, and common snipe, has an extensive range covering North America in general. Late in March Wilson Snipe 


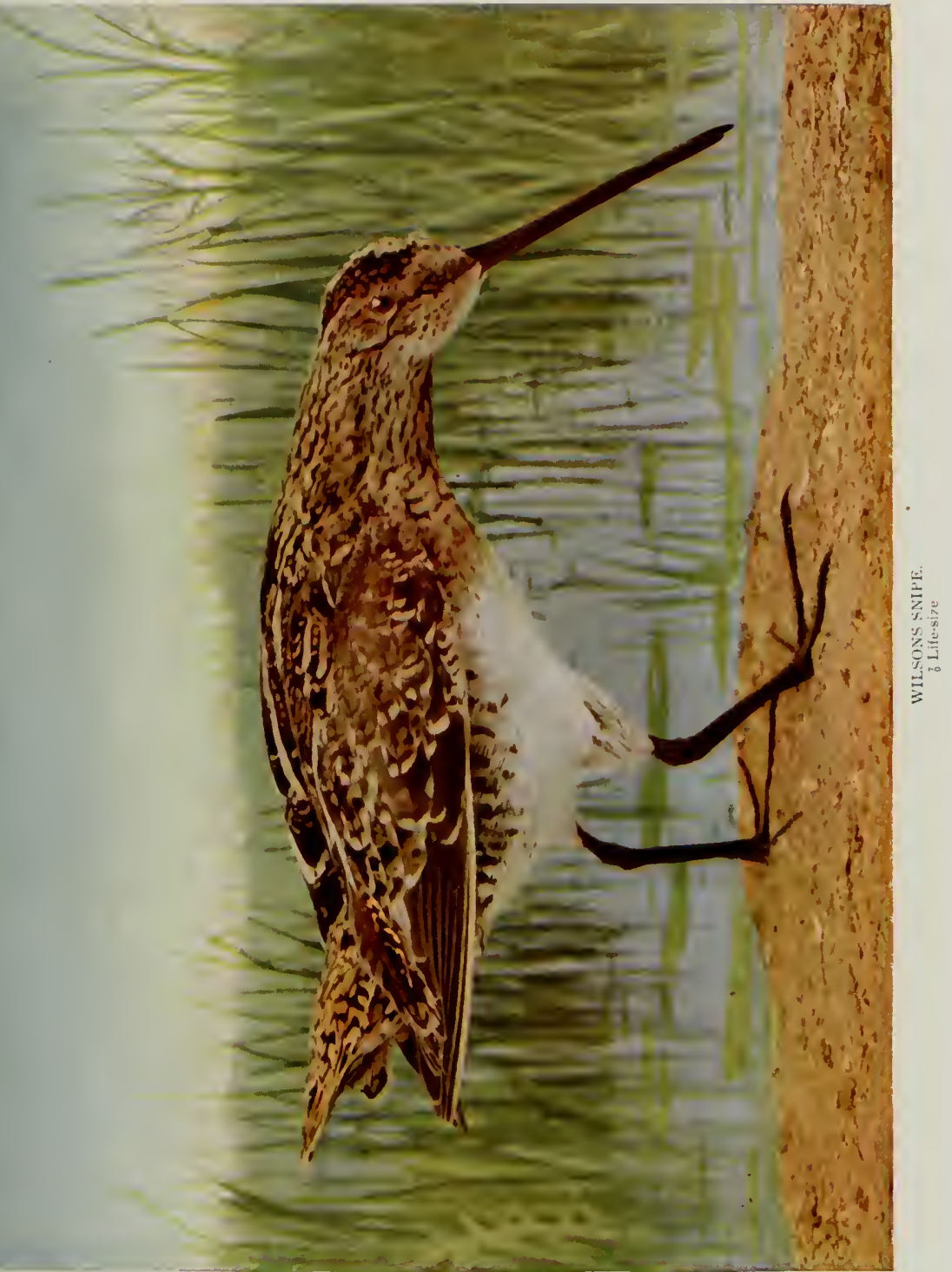



return to the Great Lakes region, resorting to cornfields, marshes, and other places wlere black, rich soil is in evidence. It feeds, after the manner of the woodcock, by probing with the sensitive bill into the earth for worms and tender rootlets.

A startled snipe springs from the ground with a "yeipyeip-yeip," flying swiftly and irregularly, but usually dropping into cover within a few seconds. After alighting it runs swiftly over the ground for several yards and again settles down to feed. This bird has been found breeding about Salt Lake, Utah, and occasionally in the states bordering Canada. The favorite breeding-grounds are from the Atlantic to the Pacific through the southern half of Canada.

The nests are mere depressions in the soft soil near a marshy place. Four beautiful eggs are deposited with the small ends together on a little bed of dead leaves and grass. The eggs are greenish-drab, marked with spots and lines of rich brown and black. In April, while searching for woodcock in the Great Lakes region, the writer has frequently witnessed the song-flight of the Wilson snipe. The first intimation that such a performance is contemplated is a clucking which is uttered in the shelter of a few rushes or a little grass. Presently a snipe rises and circles about overhead. At intervals the bird darts obliquely through the air, producing a whistling sound resembling the whiz of a missile through space. Suddenly the bird drops to the ground and resumes his clucking. He soon takes to wing again, and this time maintains a horizontal course at a low elevation until joined by the female. 


\section{THE DOWITCHER *}

The range of the Dowitcher is limited to the eastern part of North America. It has been reported as far west as the Mississippi River. It breeds in the far North, usually within the Arctic Circle. Its migration is extensive, for it winters in Florida, the West Indies, and in the northern portion of South America.

The dowitcher is one of the best known of our coast birds. It bears many popular names, such as Gray Snipe, Grayback, Dowitch, Driver, Brown-back, and Bay Bird. The generic name Macrorhamphus is derived from two Greek words-makros, meaning large, and rhamphos, meaning bill. The specific name griseus means gray, and probably has reference to the grayish color of the winter plumage.

The dowitchers are the most numerous of the seaside snipes. At the retreat of the tide, flocks will frequently settle on the shore in such large numbers and so close together that several dozen have been killed at a single shot.

Mr. Chapman tells us that "they migrate in compact flocks, which are easily attracted to decoys by an imitation of their call. Mud-flats and bars exposed by the falling tide are their chosen feeding grounds. On the Gulf Coast of Florida I have seen several hundred gathered in such close rank that they entirely concealed the sandbar on which they were resting."

In summer the general color of these birds is dark brown and the feathers are more or less edged with a reddish tinge. Underneath, the general color is light cinna- 


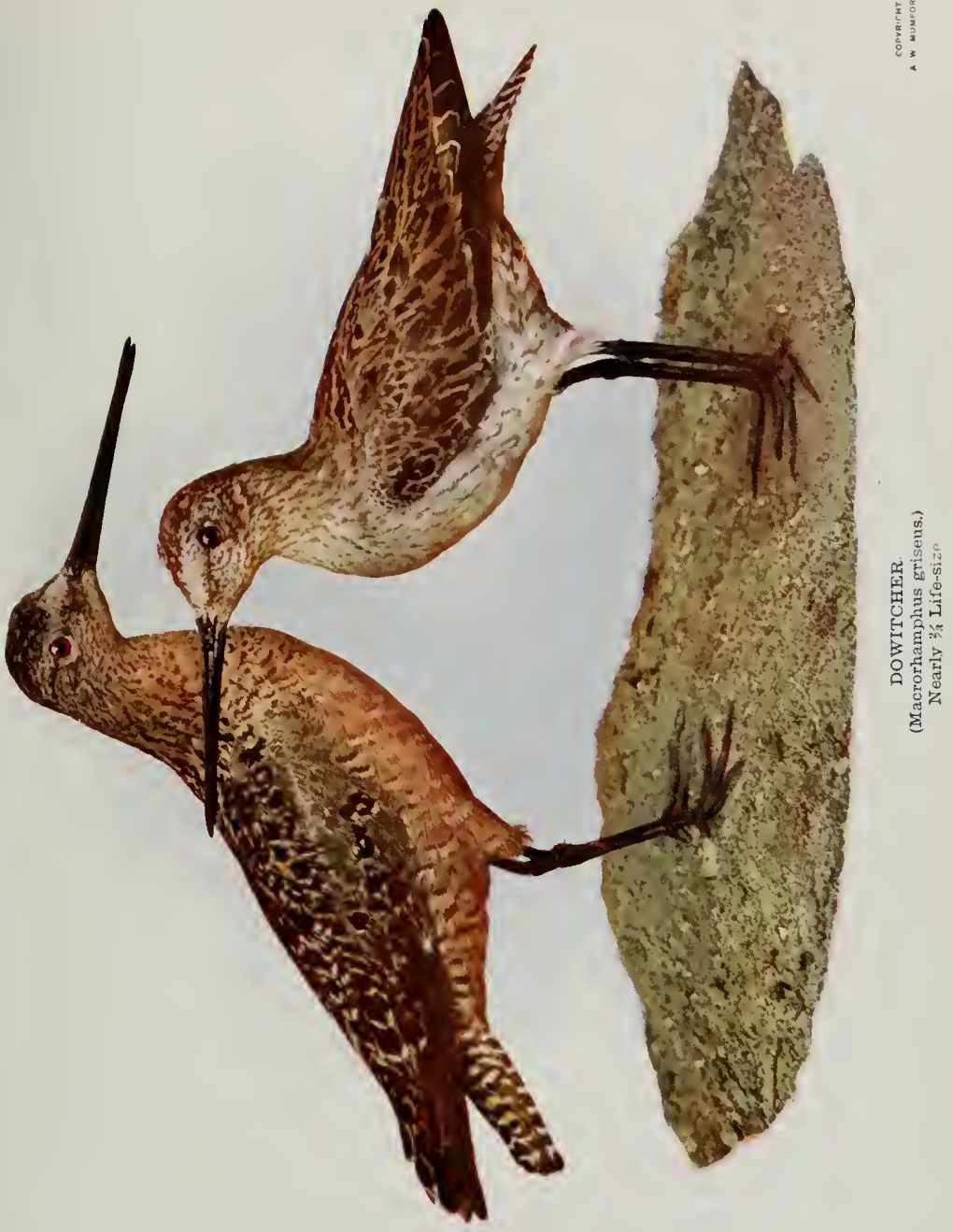





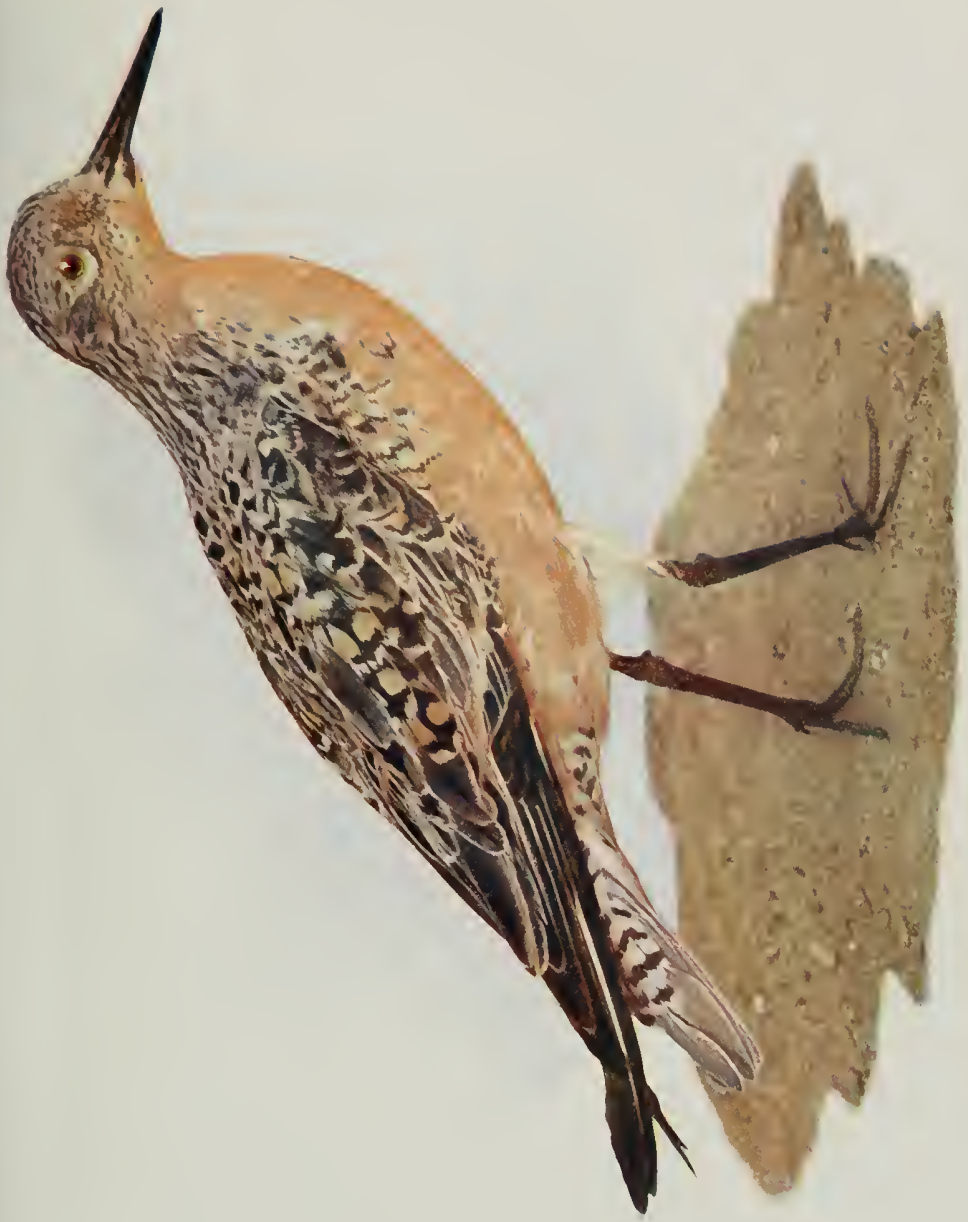

售

至

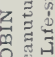

4

영 줄

比安 

mon, with white on the belly. In the winter the plumage is more gray and the under parts are much lighter in color.

This bird usually lays four eggs of a buffy-olive color, which are marked by brown, especially near the larger end.

\section{THE KNO'T OR ROBIN SNIPE*}

The Knot or Robin Snipe is a bird of several names, as it is also called the Red-breasted, Ash-colored Sandpiper, the Gray-back, and the Gray Snipe. It is quite cosmopolitan, breeding in the far North of both hemispheres, but in winter migrating southward and wintering in the climate of the southern United States and Central America. The knot belongs to the snipe family, which includes one hundred or more species, about forty-five of which are inhabitants of North America. Nearly all the species breed in the higher latitudes of the northern hemisphere. These birds frequent the shores of large bodies of water, and are seldom observed far from their vicinity. Their bills are long and are used in seeking food in the soft mud of the shore.

The knot visits the Great Lakes during its migration and is frequently observed at that time. Its food, which consists of the smaller crustaceans and shells, can be as readily obtained on the shores of these lakes as on those of the ocean, which it also follows.

Dr. Ridgway tells us that "Adult specimens vary individually in the relative extent of the black, gray, and reddish colors on the upper parts; gray usually predominates in the spring, the black in mid-summer. Sometimes there is 
no rufous whatever on the upper surface. The cinnamon color of the lower parts also varies in intensity."

Little is known of the nest and eggs of the knot, owing to its retiring habits at the nesting time and the fact that it breeds in the region of the Arctic Circle, so little frequented by man. One authentic report, that of Lieutenant A. W. Greeley, describes a single egg that he succeeded in obtaining near Fort Conger, while commanding an expedition to Lady Franklin Sound. This egg was a little more than an inch in length, about one inch in diameter. Its color was a "light pea-green, closely spotted with brown in small specks about the size of a pinhead."

\section{THE PECTORAL SANDPIPER*}

The Sandpiper is distributed through North, Central, and South America, breeding in the Arctic regions. It is also of frequent occurrence in Europe. Low, wet lands, muddy flats, and the edges of shallow pools are its favorite resorts. The birds move in flocks, but, while feeding, scatter as they move about, picking and probing here and there for their food, which consists of worms, insects, and small shellfish, tender rootlets, and birds. "But at the report of a gun," says Colonel Goss, "or any sudden fright, spring into the air, utter a low whistling note, quickly bunch together, flying swift and strong, usually in a zigzag manner, and when not much hunted often circle and drop back within shot; for they are not naturally a timid or suspicious bird, and when quietly and slowly approached, sometimes try to hide by squatting close to the ground." 


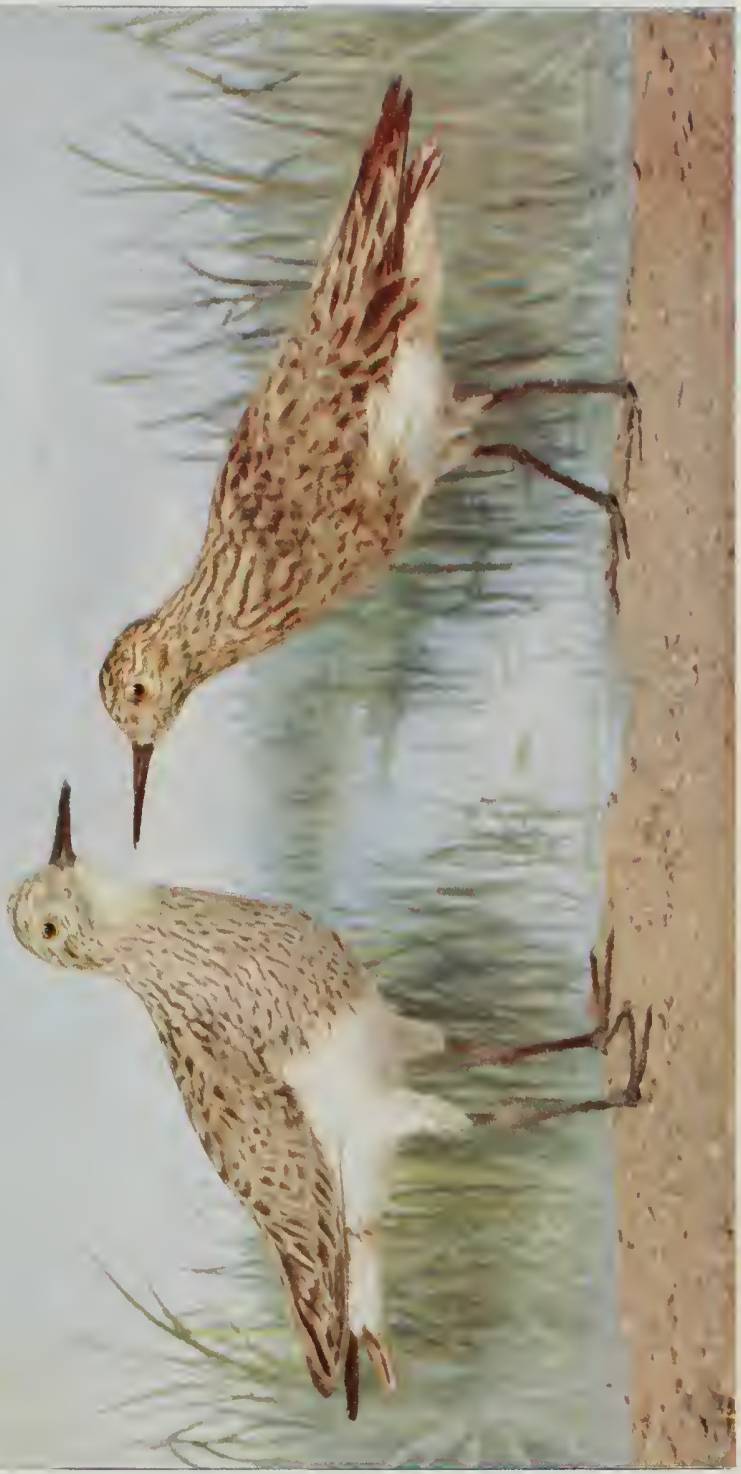

है 



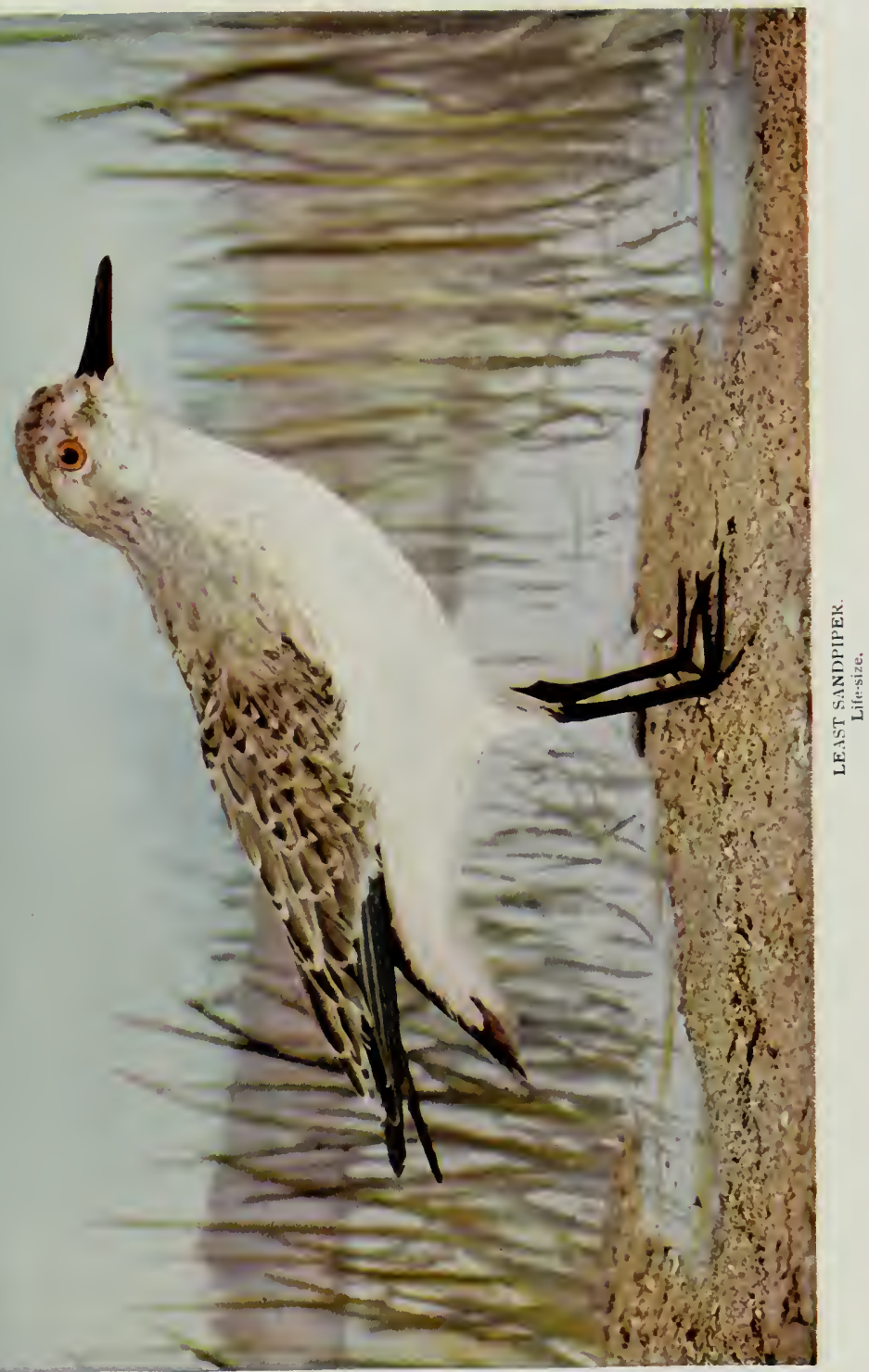



The note is deep, hollow, and resonant, but at the same time liquid and musical, and nay be represented by a repetition of the syllables "too-u, too-u, too-u, too-u, too-u." The bird may frequently be seen running along the ground close to the female, its enormous sac inflated.

Mr. Murdock says the birds breed in abundance at Point Barrow, Alaska, and that the nest is always built in the grass, with a preference for high and dry localities. The nest was like that of the other waders - a depression in the ground, lined with a little dry grass. The eggs are four, of pale purplish-gray and light neutral tint. It is sometimes called Grass Snipe.

\section{THE LEAST SANDPIPER*}

This lively, social little Sandpiper is common throughout America, nesting in the Arctic regions. It is migratory, arriving the last of March to the first of May, a few occasionally remaining until November. It has been found breeding as far south as Sable Island, Nova Scotia, but its usual breeding grounds are north from Labrador and Alaska to Greenland, wintering from California and the Gulf States southward. It is more restless and active than the larger sandpipers, but in habits it differs little, if any, from them. It runs nimbly about, often with the large waders, feeding around and beneath them, apparently heedless of danger. While watching the birds, they will often pass close to the feet, but at the least motion the whole flock will spring into the air "like a flash, with a startled 'Peep, peep!' and in a compact form swiftly sweep about 
in an uncertain manner, canting from side to side, showing rapidly the white beneath and the dark above, a wavy, pretty sight, the white at times fairly glistening in the sunlight." When migrating or going any distance, their flight is steady and direct.

The sandpiper's nest is placed on the ground in a slight depression, scantily lined with leaves and grasses. The eggs are three or four, of ground color, cream buff to light drab, spotted and blotched irregularly with varying shades of brown, thickest about the larger end.

The black and white outlines which are often seen of this bird make it possible, perhaps, to recognize it, but the perfect likeness which we present will enable the observer to distinguish it at a glance from all others of the family, of which there are about a dozen well-known species.

\section{THE RED-BACKED SANDPIPER *}

Very early in the spring the Red-backed Sandpiper leaves its winter home in the States and countries bordering the Gulf of Mexico and starts on its long journey to the cooler region of the far North. It arrives in Alaska early in May, in full breeding plumage. The note of the sandpiper is not loud, but has a rich, full tone, difficult to describe, but pleasant to hear.

The red-backed sandpiper is not a bird architect, and it does not build even a simple home. A slight hollow on a dry knoll, which commands a clear view of some body of water, is the site usually selected. Here the eggs are laid, either upon the dry grass already in the hollow or upon a 


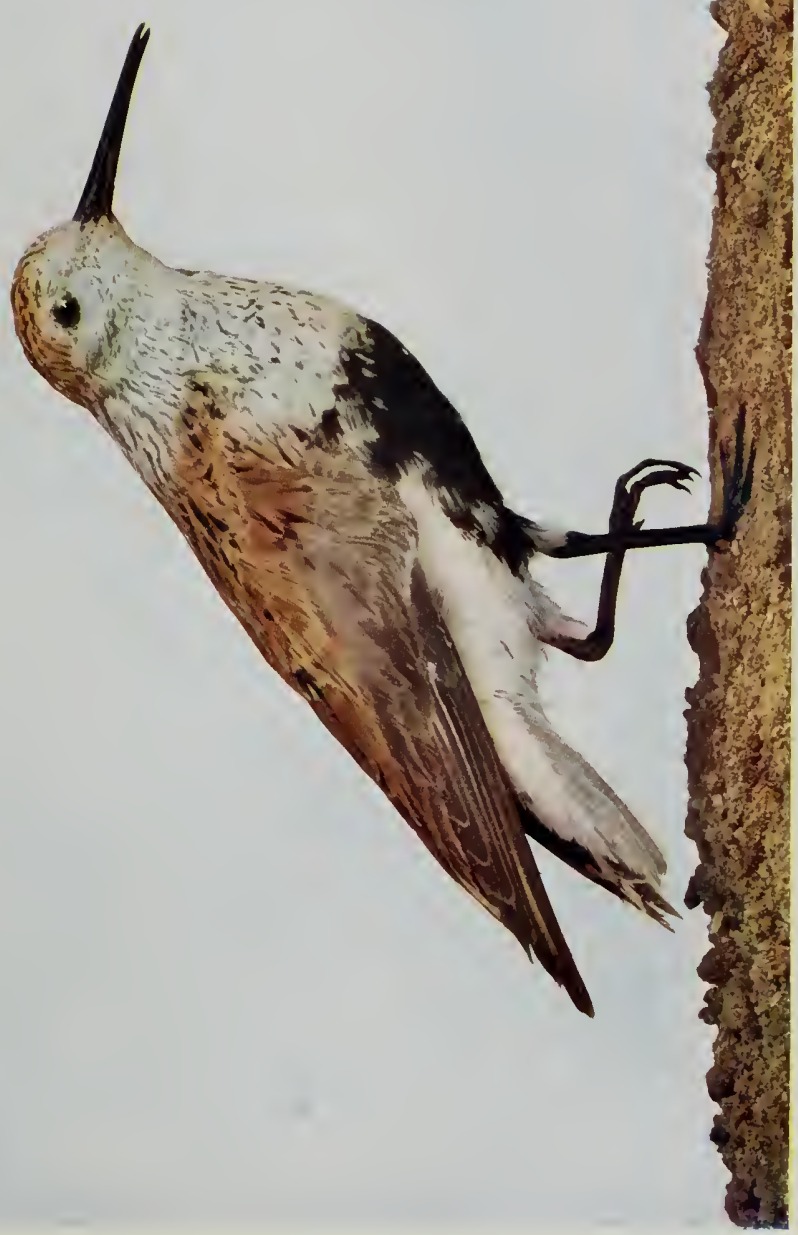

落

今

ค

年

क

소룽

ॠ

4

म

ล่

올

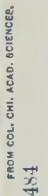





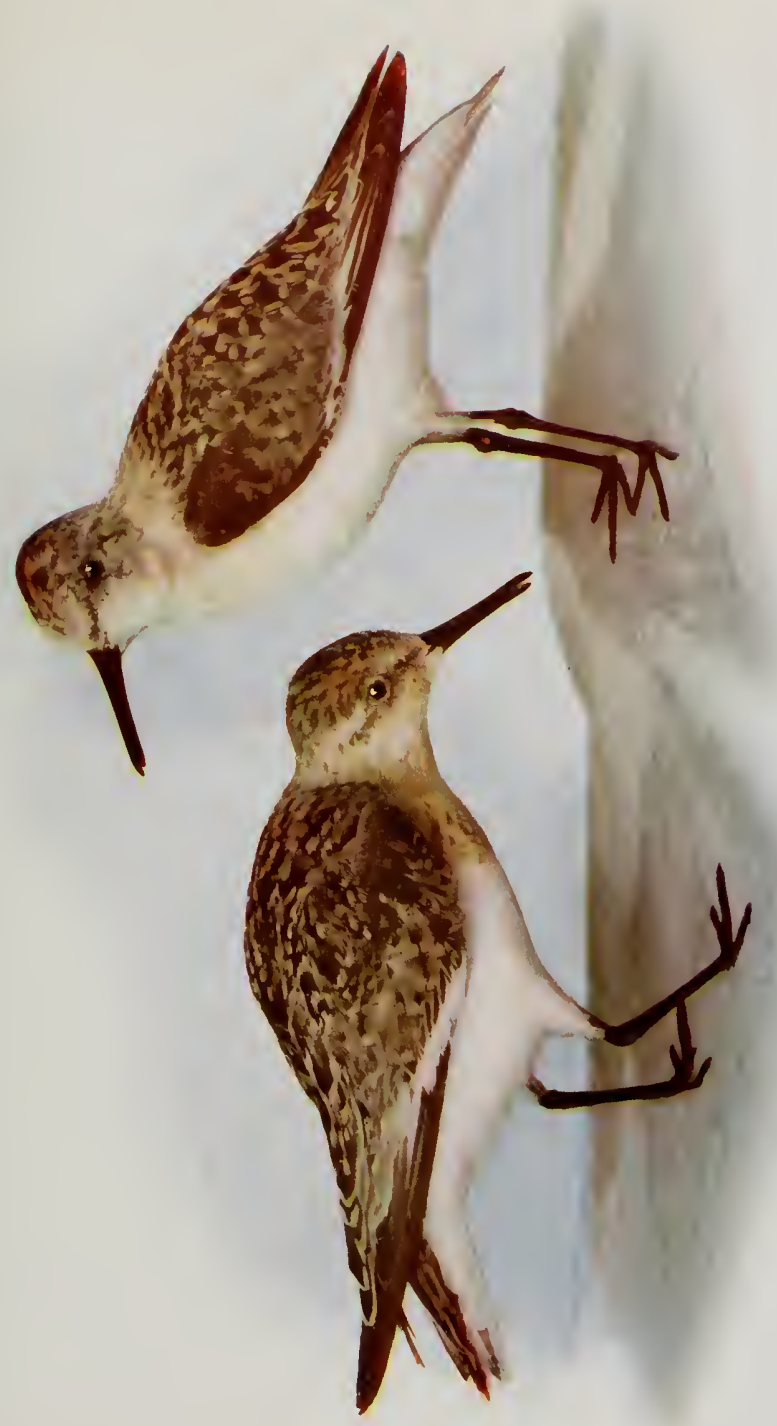

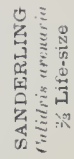



few bits of leaves, twigs, and grass hastily gathered and placed without order. After the appearance of the eg'gs the male seems to realizc the responsibility of family cares, for his merry song ceases and he devotes his share of time to sitting on the nest, protecting the eggs with his warm body. That this is the case is shown by the bare patches that appear on his breast at this season.

With such a home as is prepared for their reception, it is not surprising that the little red-backs leave the nest as soon as they are hatched, and freely run about. When frightened, they readily conceal themselves by sitting on the ground and remaining quiet.

This species exhibits considerable variation in the color of its plumage. In the spring and summer it may be known by the black patch on the belly and reddish color of its back, which is mottled with white and black. At this season it is often called Blackbreast. In the fall and winter the upper parts are brownish-gray in color and the under parts are whitish. It is then frequently called the Leadback. Though a beach bird, it is not inf requently met in grassy marshes, and by some it is called the Grass-bird.

\section{THE SANDERLING*}

This little shore or beach bird is sometimes called the White or Surf Snipe, and the Ruddy Plover. It breeds only in the colder portions of the northern hemisphere and migrates southward, even beyond the equator, where it makes its home during the winter months. It frequents chiefly those regions near the surf-beaten shores of the 
oceans. It is also a common visitor to the beaches of larger inland waters. On these shores its beautiful form and habits are very noticeable. It walks and runs in a dignified and graceful manner as it chases the receding water searching for its food.

The pure white plumage of the under parts of the bird is a striking characteristic as they reflect the sunlight during flight.

The feet of the Sanderling are unlike the other members of its family, being without a fourth toe, entirely divided, and without a membrane. This indicates that it frequents firm surfaces and that it is fitted for running and walking upon the long, shelving beaches over which the tides and surf roll, leaving an abundance of its particular food.

The nest of the sanderling, rudely constructed of dried grass and decayed leaves, is placed in a depression in the ground, so situated as to be protected by the natural vegetation of the region. The eggs, usually three or four in number, have an ashy or greenish-brown ground color, and are finely spotted with different shades of brown.

The food of the sanderling consists mainly of sea worms, small bivalve shells, and crustaceans, though it will also eat buds and insects. It would seem as if its hunger was never satiated - always busy, always moving. These expressions describe its habits, as, with its fellows and other snipe with which it associates, it seeks its food in the wake of the retreating wave, and turning, runs before the incoming water, which seldom engulfs it. To watch their peculiar antics is a most interesting recreation. 


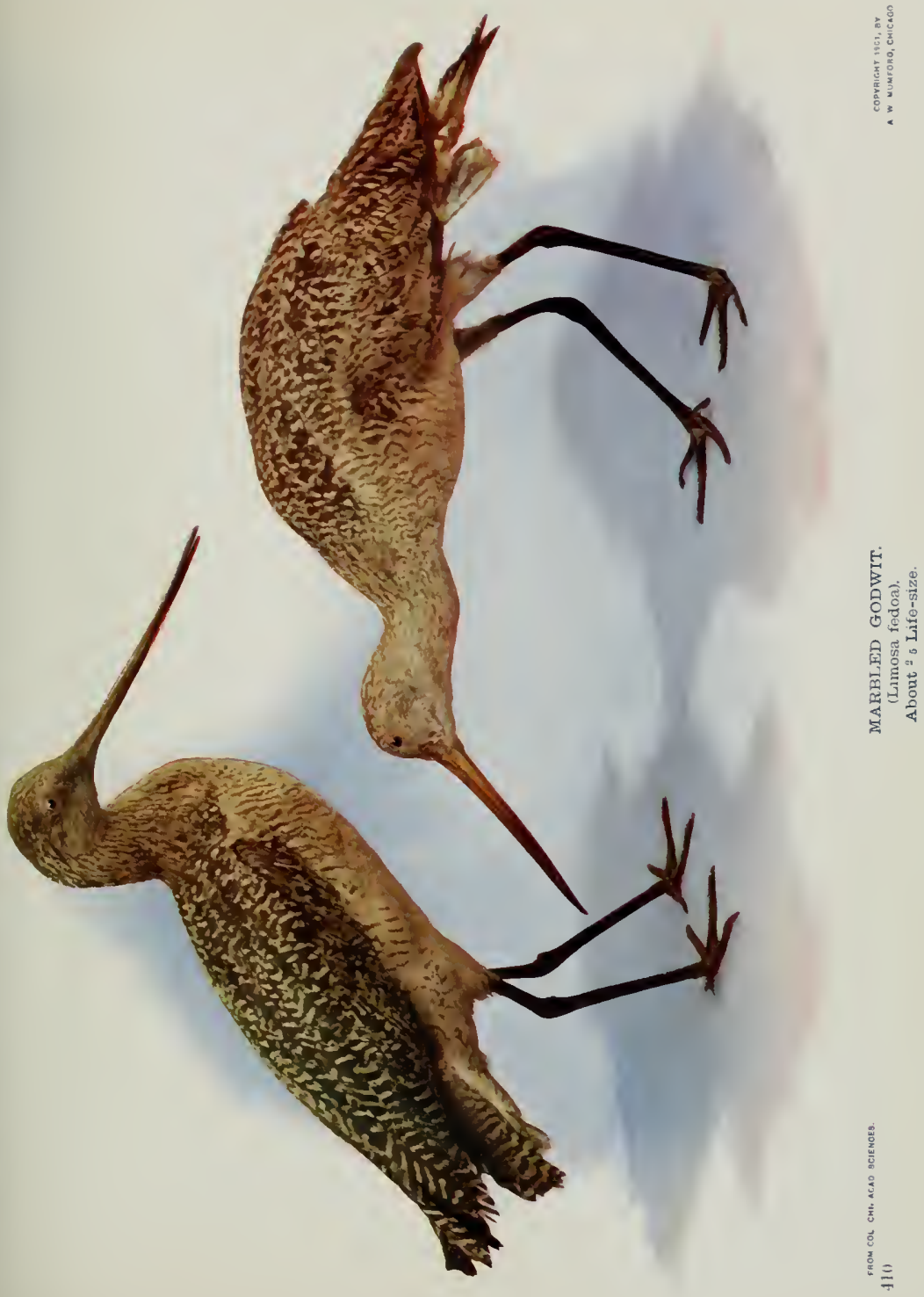





\section{THE MARBLED GODWIT*}

As is the ease with many of our game birds, this species bears a number of common names, such as the Straightbilled Curlew, the Marbled or Brown Marlin, the Red Curlew, and, among sportsmen, the Dough and the Doe Bird.

The geographical distribution of the Marbled Godwit includes the whole of North America, though it is infrequent on the Atlantic coast. Its nesting range is chiefly limited to the interior from Iowa and Nebraska northward to the Saskatchewan. In winter it migrates to Central America, Cuba, and the northern part of South America.

In company with the long-billed curlew and some species of sandpipers, it builds its nest on the grassy banks of rivers and ponds, usually in some natural depression. Occasionally, however, the nests are found on moist prairies, some distance from a stream. In these grass-lined nests are laid the three or four bright olivaceous, drab, or creamy-buff eggs that are variously spotted or blotched with varying shades of brown. They are domestic and seemingly devoted to their fellows. When one of their number is wounded and unable to fly, they will frequently remain in the vicinity, flying around the spot where lies their wounded comrade.

Its food consists of the smaller crustaceans, worms, snails, insects and their larvæ. These are captured from the surface of the water, on the shore, or are probed for with the long, sensitive bills, in the soft soil of the banks or under shallow water. When feeding, it moves in an 
easy and graceful manner. Its grace and dignity well merit the saying that "It is one of the most beautiful of the birds sought by the sportsman."

\section{THE GREA'TER YELLOW-LEGS *}

No bird bears a more appropriate name than does this wader with its long yellow legs. In many localities, Greater Yellow-shanks is the name by which it is commonly known, and who that is acquainted with it does not recognize that the name Tell-tale is also very characteristic of the bird's habits? When flushed, the Yellow-legs excitedly rise from their feeding grounds, uttering loud whistling notes which cannot well be expressed in syllables, but are easily imitated by the hunter.

None of the waders is more graceful than the Greater Yellow-legs. They frequent watery bogs and the muddy margins of streams. There they search for their food of insect larvæ, small crustaceans and fish, worms, and small mollusks, frequently wading in water deep enough to reach more than half way up to their bodies. In flying, their necks and legs are extended to their full length. Their flight is swift, and frequently they rise to great heights. When about to alight, they circle several times orer the locality before settling. When they do alight, they stand for a few moments with their wings beld over the body and pointing directly upward. It has been suggested that this habit arises from a desire to test the firmness of the soft soil before they bear their weight upon it. When wading, they move about in a quick and apparently excited man- 


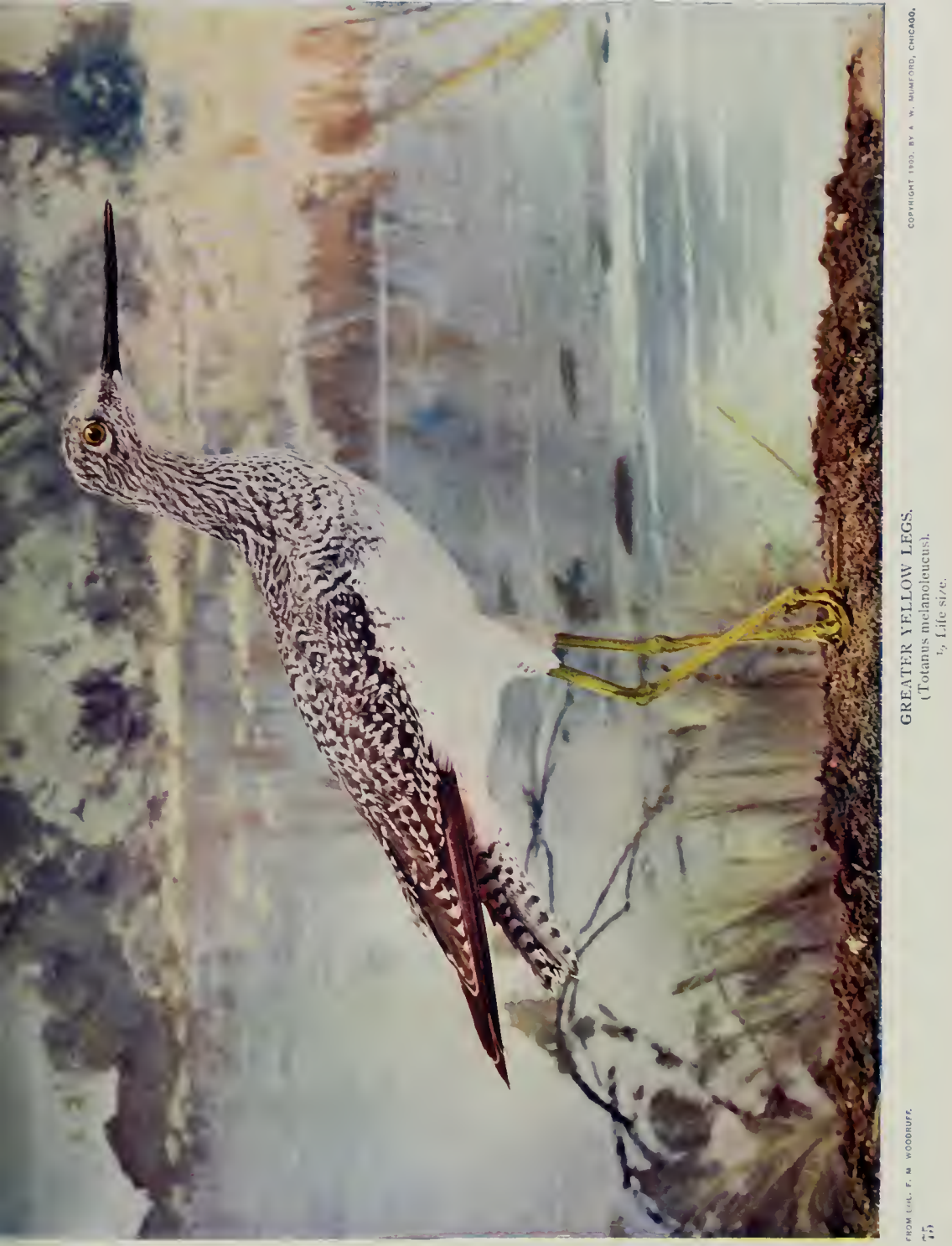





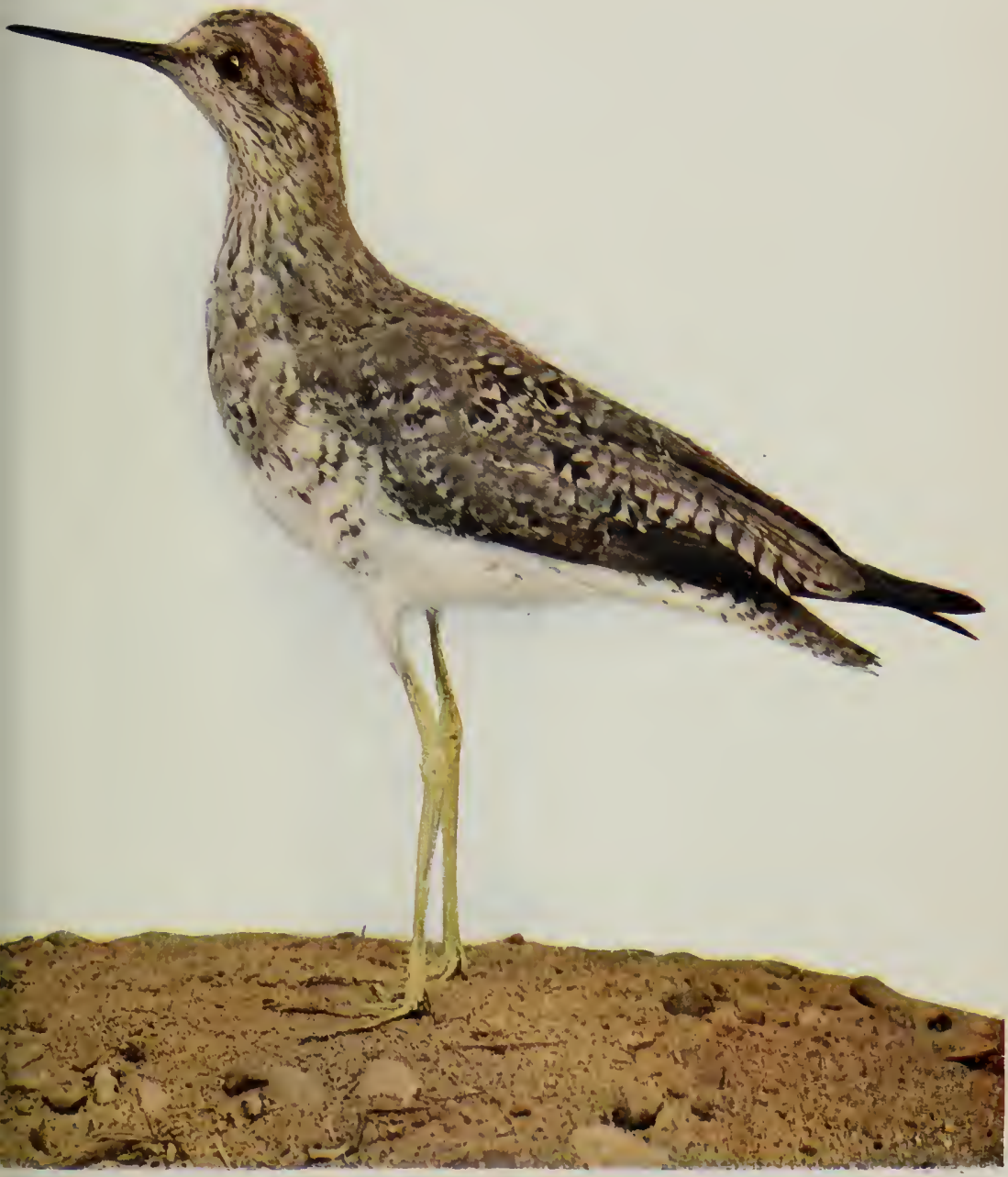



ner, "with much balancing and vibrating of the body and graceful darting of the head in various directions," while they seek for their food.

The greater yellow-legs exhibits great anxiety and sympathy for a wounded companion, and for a time seems to forget its own danger.

The range of the greater yellow-legs is an extensive one which includes America in general. It breeds upon northern Illinois and Iowa northward, and migrates south in the fall as far as Patagonia, some wintering in the Gulf States. In its migrations, it seldom remains more than a day or two at any one station, though the fall passage is somewhat slower than that of spring, when it seems to be in haste to begin the work of nesting.

\section{YELLOIV-LEGS}

This is the bird commonly known to the sportsman as the Lesser or Summer Yellow-legs, or Yellow-legged Plover. In general habits and color there is little difference between this and the greater yellow-legs. The present species, however, is probably more partial to the interior during migrations. Yellow-legs winter from the Gulf to Patagonia. Their breeding range is chiefly, if not entirely, north of the United States, but many summer in the Great Lakes region. These waders, like others of their family, do not always breed until they are two years of age, and so many are encountered during the spring and summer in latitudes quite southerly for this sub-arctic shore bird. Arriving in the Great Lakes region after the first warm rains of April, 
the yellow-legs tarries in wet meadows until the last of May. Two or three days of almost continued flight earry these powerful fliers into the colder climates of Labrador and Hudson Bay.

The three or four eggs are deposited soon after the birds arrive at their breeding grounds. I have a set of eggs from Alberta, Canada. 'The background is light greenish-drab, and the markings of rich brown and purple are clustered about the large end. These are large for the size of the bird, and the young emerge from the shell strong and able to run in twenty-four hours. The southward flight commences early in August, and the birds linger in temperate North America until cold weather lessens their food supply, when they resume their southward journey to the equator and beyond.

\section{WESTERN WILLET}

The Willets are the largest of our short-billed shore birds; in fact, they are exceeded in size only by the curlew and godwits of the entire shore bird family.

The true willet is an Eastern form, occurring on the Atlantic seacoast, breeding usually on the islands opposite Georgia and the Carolinas.

The Western Willet is very similar, but slightly darker in plumage, occurring from western Indiana and southern Texas, up the Mississippi Valley, through Illinois, Dakota, and Kansas, into Canada.

These birds partake of the habits of the true plovers, sandpipers, and especially the yellow-legs, like which they usually travel in small flocks, and are extremely noisy, 


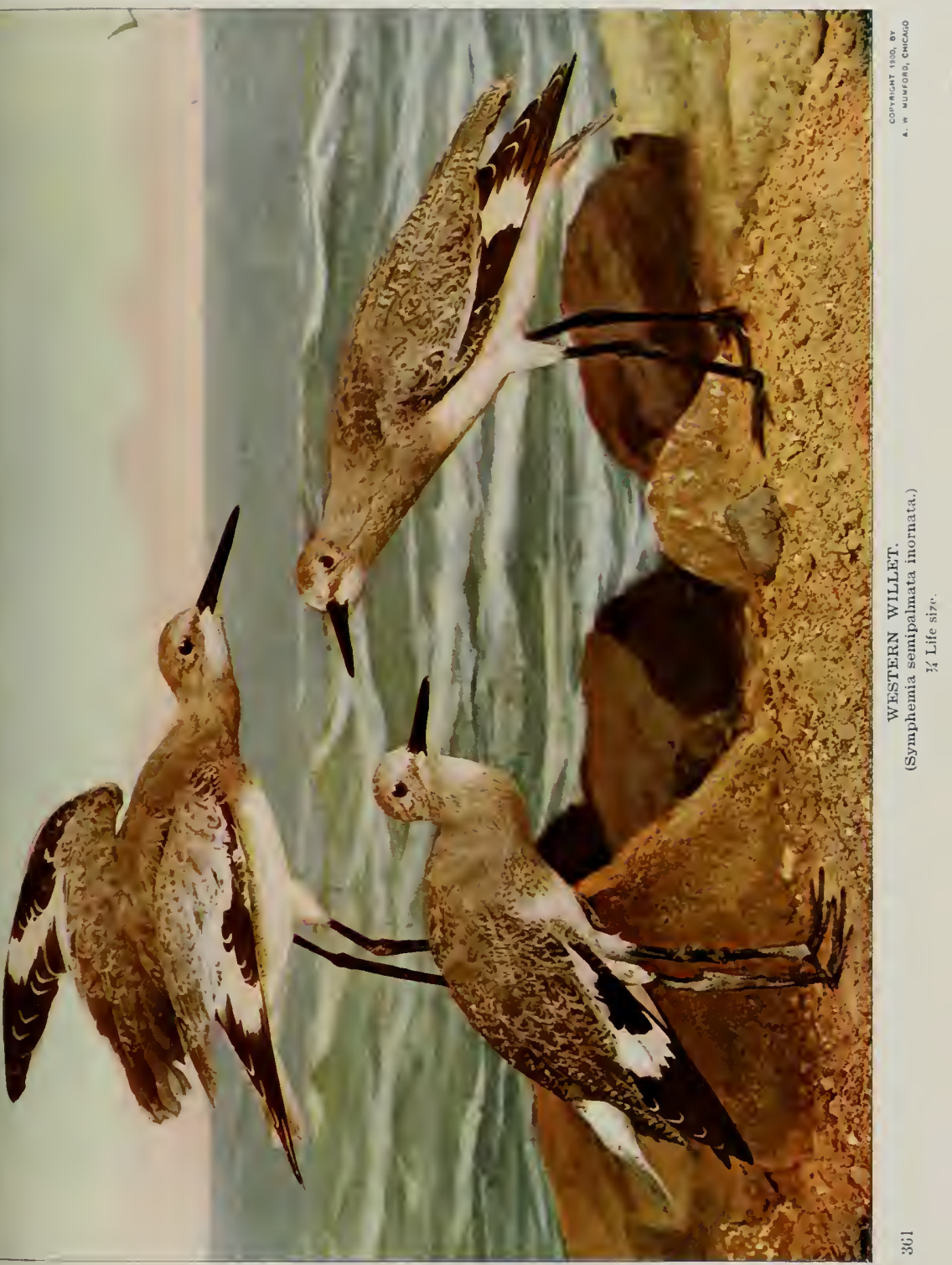



especially during the breeding season. It is a common occurrence, however, to meet with a solitary bird feeding on the sandy beach of our large inland lakes, or on the edges of marshes. They often breed in small colonies.

Willets are beautiful birds when on the wing. Their flight is strong, and the black and white effect is a conspicnous field mark. Their food consists of small insects and aquatic life, which they obtain from the surface of the ground in both wet and dry places.

The bird takes its name from the clear, flute-like notes, which are uttered in syllables sounding like "Pill-will-willet, Pilly-willy-willet!" repeated in rapid succession.

The western willet is found nesting on the prairies of Minnesota, Dakota, and Manitoba. Unless the parent bird has been sitting upon her eggs for some days, she vacates the $n_{\llcorner} \cdot s t$ at the slightest indication of danger and approaches the intruder from the opposite direction. The nests, are therefore, very difficult to find, unless the eggs are well incubated, when the mother sits close, vacating her nest when the intruder is almost upon her. The nests are often built in clumps of grass where the water is a few inches deep, or on a grassy slope of tableland overlooking the water.

On Mustang Island, in the Gulf of Mexico, the western willet breeds in colonies. Arriving on the island, the ornithologist is greeted from all sides by the male birds circling about overhead, calling so incessantly that the intruder hears nothing else until he leaves the island, and the birds settle down into the marsh grass to resume their nesting. The four handsome, pear-shaped eggs vary greatly in color. 


\section{UPLAND PLOVER}

This handsome wader with a dove-like disposition, though a true plover, is often called the Bartramian Sandpiper, the Field Sandpiper, Prairie Pigeon, and Quaily.

These birds breed from New Jersey, Illinois, and Colorado northward, wintering in South America. Though shy of footmen, they show little fear of those on horseback. Protected by plumage resembling dry grass, they are difficult to detect.

Several years ago I was walking through a pasture, when one of these birds approached the roadside and with upraised wings alighted on a fence post and eyed me euriously. Her plaintive alarm note was a quavering whistle quite in keeping with the way she folded her long pointed wings. Two years later, when in the same locality, I was walking against the wind one warm day, when a bobolink fluttered to the grass six feet ahead. Parting the grass and weeds, I decided to secure this nest for a group, and settled myself preparatory to making a few notes. After some fifteen minutes I placed one hand behind me to arise, when my finger-tips touched something soft, and a bartramian warbled from a tussock within an ar'm's length. She was a "crippled bird," and her notes indicated the utmost distress.

During the nesting season the male bartramian mounts high in the air, and on quivering wings utters a long-drawnout, plaintive whistle. 'This sound, when first heard, usually produces an uncanny effect upon the listener, who is unable 


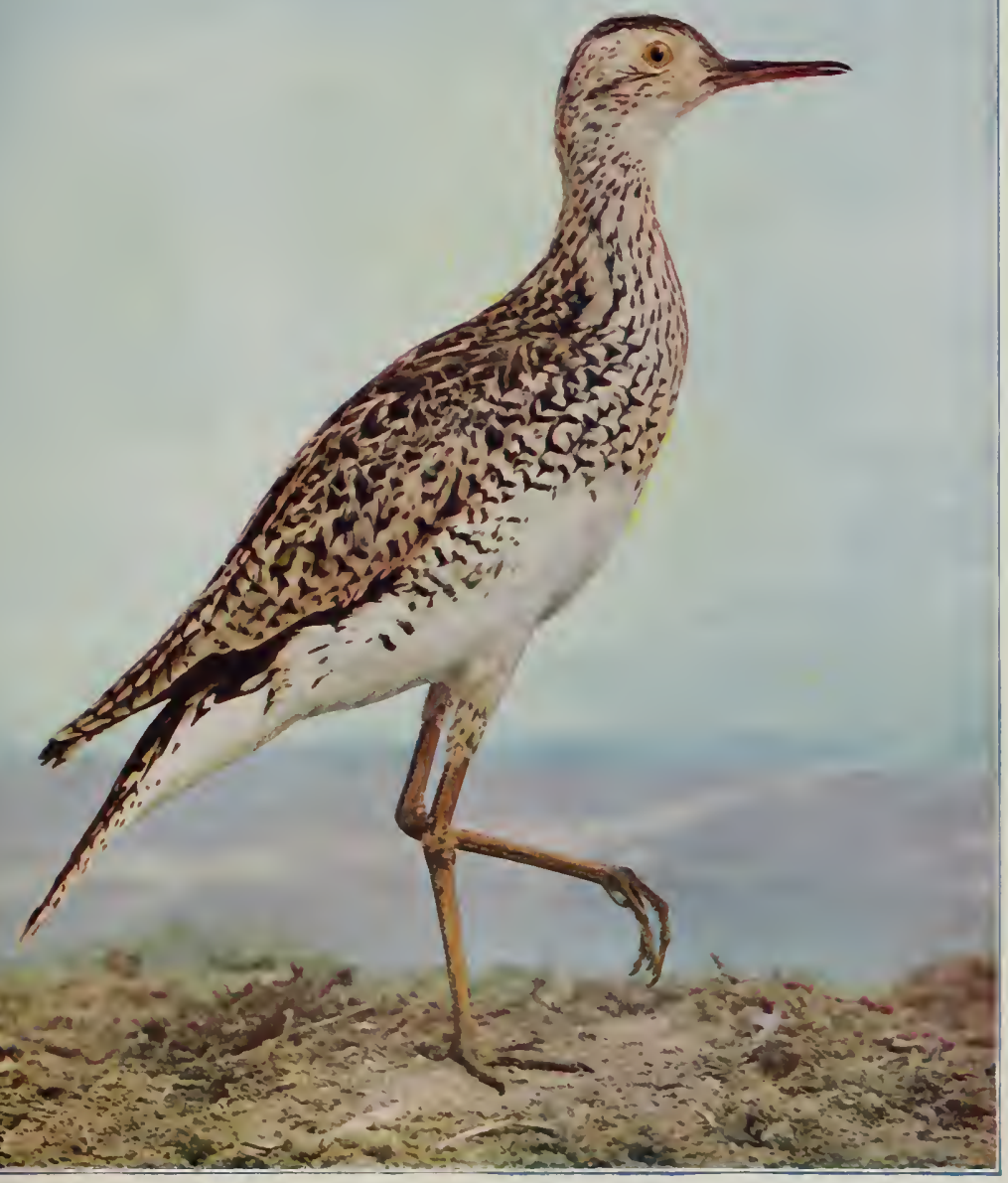

B.IKTR.IIIAN S. NDPIPER. 



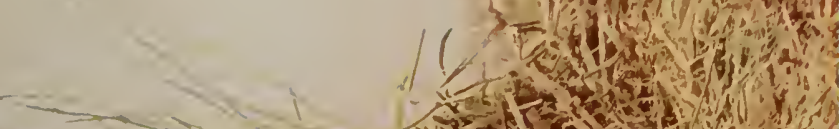
3 a $\rightarrow$ on. Q -

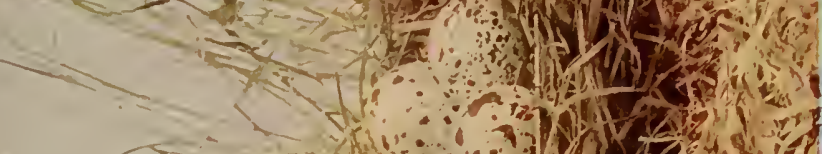

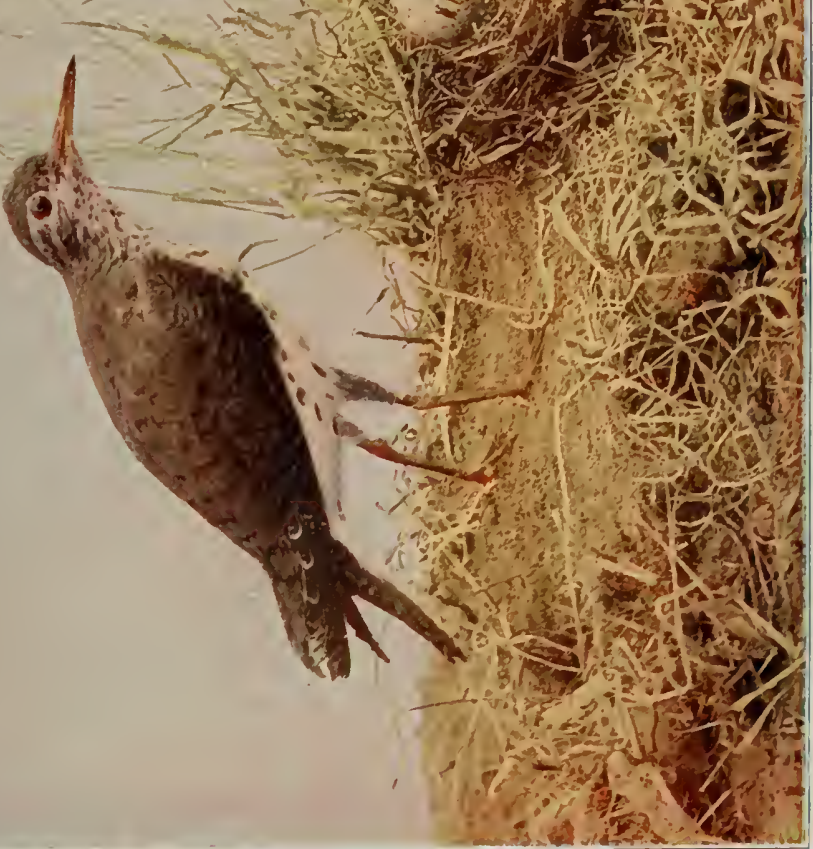



to identify its author, which appears outlined against the sky as a mere speck. Presently the bird volplanés to the earth and runs nimbly over the grass in a most unconcerned manner.

The four large, pear-shaped eggs rest in a grass-lined cavity with their points together. The background of the egg varies from creamy-buff to a decided clay color. The eggs are marked with spots and blotches of dark brown and lilac.

\section{SPOTTED SANDPIPER}

The Spotted Sandpiper, Tip-up, or Peetweet is probably the commonest and most familiar of our small wading birds. It is a typical representative of the large family of shore birds, and is found from Brazil northward to the Arctic regions about Hudson Bay and upper Alaska. They breed throughout their North American range, spending the winter about the Gulf Coast and southward. Scarcely any of our artificial lakes or lagoons in our parks are without a pair of these restless little birds. They run swiftly orer the pebbly beaches, calling in shrill whistles "peetweet" incessantly, as they tilt the body forward and backward.

They habitually fly so close to the water as barely to keep the tips of their long wings from touching. So partial do they become to certain spots along the shores, that, if disturbed, they return to the spot from which they were originally disturbed, as soon as the intruder has passed.

The eggs are laid during the second and third week of May. Grassy or weedy spots close to the water's edge are covers under which the female scratches a slight hollow, 
lining it sparingly with dry bits of grass and stems. Four pointed eggs are laid. They have a buffy or clay background, and are daintily and heavily marked with black and umber. The little spotted sandpiper is the same size as our cowbird, but deposits an egg three times as large. The young have so developed within twenty-four hours after hatching that they may be seen following their parent about the edges of our creeks and ponds.

\section{LONG-BILLED CURLEW}

This king of shore birds is the largest of his tribe, and seems to reign supreme in the territory over which he ranges. The Curlew has retreated since the settlement of the middle and western United States, as not many years ago it was of regular occurrence from the Atlantic to the Pacific, while it is now rare east of the Mississippi. Vast stretches of uncultivated lands of the West still afford the curlew suitable feeding and breeding grounds, so they still abound in the prairies of Nebraska, Colorado, and Montana. During my trip up the Yellowstone River, in 1906, I found this bird far out on the prairies, in company with upland plover and the sage hen. During the heat of the day the birds appear in pairs about small alkali pools, where the remarkably long bill is perfectly adapted for removing crawfish from their holes.

I watched a pair through my field glasses as they were feeding about a pond. Presently they flew to the distant hills. Long had I wished to locate a curlew's nest. The female had undoubtedly returned to her eggs. Distance 


in the Western country is deceptive, so I walked fully two miles before raising the suspicion of the male. He circled about, coming within three feet of my face and suddenly darting upward. I scanned every foot of ground, and found, after two hours' search, that the wary male had led me five hundred yards away. I retraced my steps to the spot where he first attacked me. He became frantic in his efforts to again mislead me, but I continued straight ahead and presently he was running about the ground in front of me. I dropped my hat, to mark the spot, even if the vegetation was too scant for concealment. Finally I saw the female lying perfectly flat with neck and bill on the ground. She was completely surrounded by prickly pears, and so, safe from prowling animals and reptiles. I advanced, when she arose, shook herself, and ran rapidly away. The male was calling so noisily that seven other curlews joined in the attack.

The four eggs rested in a little hollow with the points together. They were pear-shaped, having a pea-green background beautifully spotted with different shades of maroon. These eggs are slightly larger than those of our domestic turkey, though laid by a bird only one-fourth as large. This gives a good idea of how large are the eggs of the shore bird in proportion to those of other species. They perform such extended migrations that these birds have no time for nest building, and the young attain such development and strength.before hatching that they are able to care for themselves in a few hours. These downy young resemble the adult bird but little. 'They are of a brownish color, and have straight bills. 


\section{THE ESKIMO CURLEW*}

The Eskimo Curlew, or Dough Bird, as it is frequently called, has an extensive range covering the entire length of eastern North America. In the United States, it is known only as a migrant, for it seldom winters within its borders, but passes southward into Central America and throughout South America. As it nests within the Arctic Circle, it is seldom seen south of the Canadian border during the summer months. The northward migration takes place during the last of April and early in May; the southward begins about the first of September. Its favorite feeding hours are at the beginning and at the close of day, and during its migrations it frequents grassy marshes and neighboring fields, where it finds a plentiful supply of insects, earthworms, and mollusks.

While in the North, the curlew's food consists to a great extent of berries, especially the small deep purple berry called the bear or curlew berry. Dr. Coues says that it feeds so extensively upon this berry that the intestine and the "legs, bill, throat, and even the plumage are more or less stained with the purple juice." These berries are so abundant that the curlew becomes exceedingly fat, and forms a dainty morsel for the table of the epicure.

The little curlew, as the Eskimo curlew is sometimes designated, very closely resembles the short-billed curlew in the markings of its plumage, but its much smaller size is a ready mcans of distinguishing it. It also frequents fields more commonly than the short-billed species. Not 


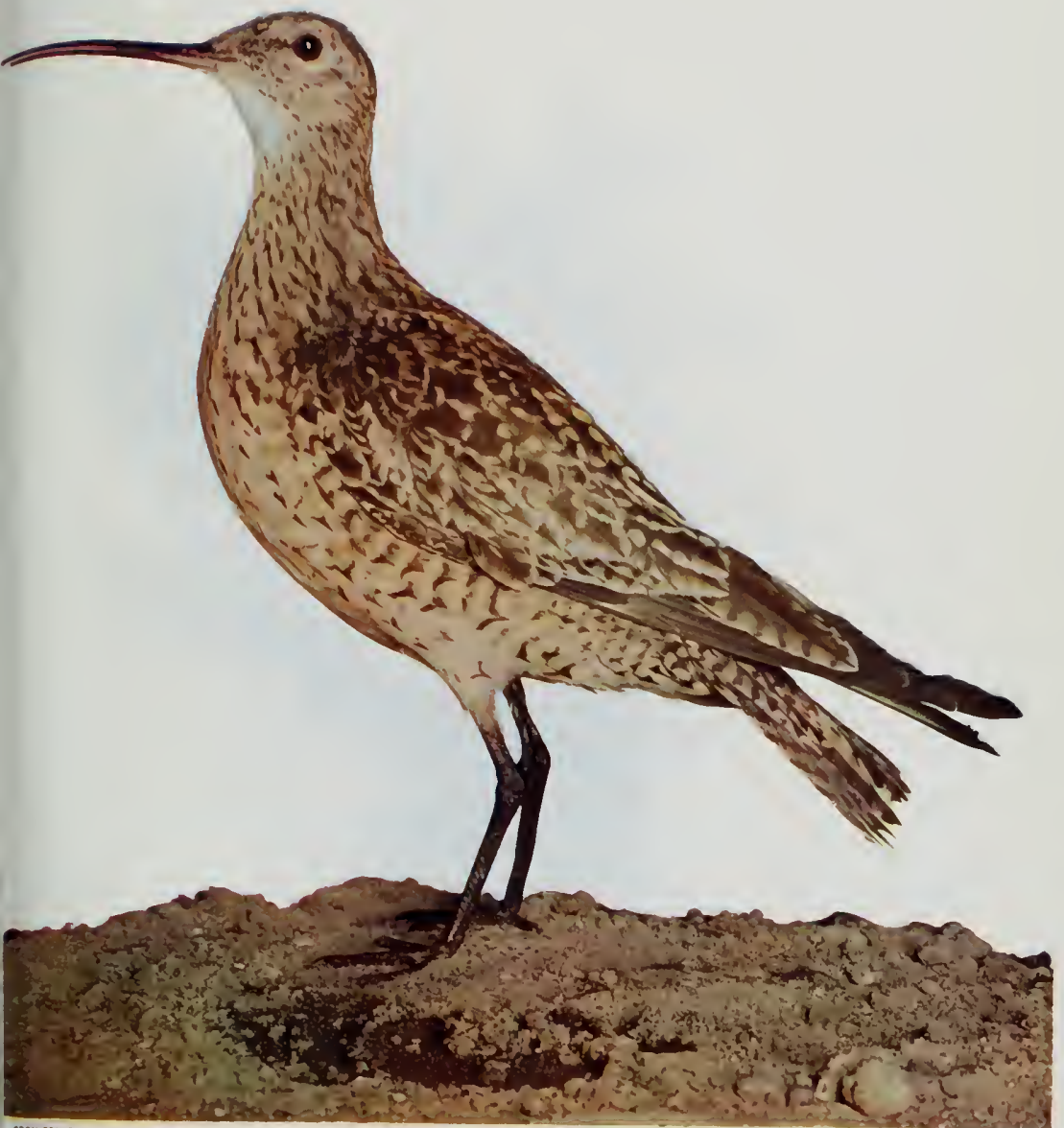

HOW COL CMI, ACAS. SCIEMCES 



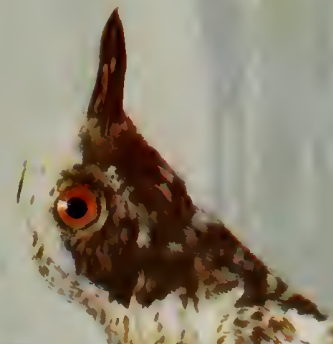

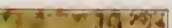

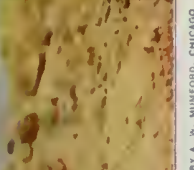

$P$ it. $y$, in

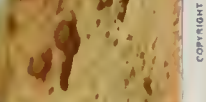

aj: i

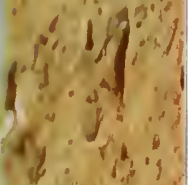

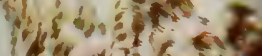

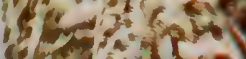

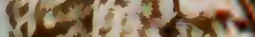

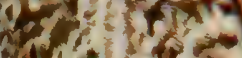
Whis in the Hof $x^{2}+2$

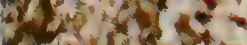
expresing

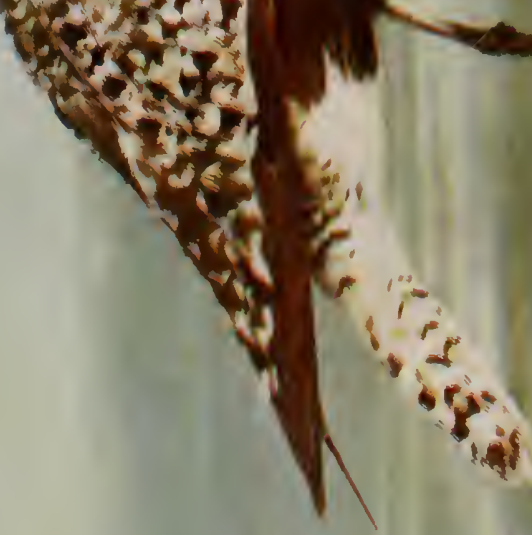



infrequently it is found in company with the golden plover during its migrations through the interior of the United States.

In its habits the curlew quite closely resembles the plover. Mr. Mackay says that "In migration they fly in much the same manner, with extended and broad-side and triangular lines and clusters similar to those of ducks and geese at such times."

\section{BLACK-BELLIED PLOVER}

The Black-bellied Plover, or Beetle Head, is nearly cosmopolitan; it breeds in the Arctic regions and in America, winters from Florida to Brazil.

The bird in its various phases of plumage closely resembles the golden plover, but can be positively identified at any season of the year by the presence of a hind or fourth toe, which is wanting in all other plovers. These birds have the legs and wings remarkably developed. Plovers lack the long boring bills which are possessed by the sandpipers and woodcocks. The bills of these common tide birds are short and stout, and they pick their food from the surface of the earth, feeding on both high and low land.

In spring and summer the breast is one mass of jetblack feathers, the upper wing coverts, tail, and back being light gray. The feathers are white with innumerable little bars of dark brown, giving the bird a beautiful gray effect, so in contrast to most birds which are darker above.

The autumn migration is apt to be along the seacoast when the birds fly with the wind. During the spring migra- 
tions the golden plover frequently inhabits the prairies and uplands, but the present spccies is usually met with along the edges of streams and lakes, as it seems partial to feeding in muddy places. Here their plumage scrves as a great protection, their lightly mottled backs blending perfectly with the rippling water beyond as they feed on beaches.

In spring these birds pass northward leisurely, often rcmaining in the United States until the first of May; in migrating they $\mathrm{fly}$ in lines or in ranks like geese. Their summer homes are in the Arctic regions, being most common upon the mossy barrens about IIudson Bay and Alaska. As the birds run swiftly over this gray vegetation they are hardly noticeable to the untrained eye, so remarkably do their backs blend with the sparse vegetation.

The four eggs are laid in a little hollow, usually on an elevated spot in wet territory. The eggs are large for the size of the bird, but the young come into the world so heavily clad with down that within two weeks they are able to shift for themselves.

\section{AMERICAN GOLDEN PLOVER *}

Golden Yellow Rump is one of the names often applied to this most beautiful member of the plover family, which is thus made conspicuous and easily recognizable. It is found everywhere in the United States, from the Atlantic to the Rocky Mountains, but is rare on the Pacific coast south of Alaska. 'They are seldom found far inland, their natural home being on the seacoast, occasionally frequenting marshy or wet grounds, though as a rule they prefer 



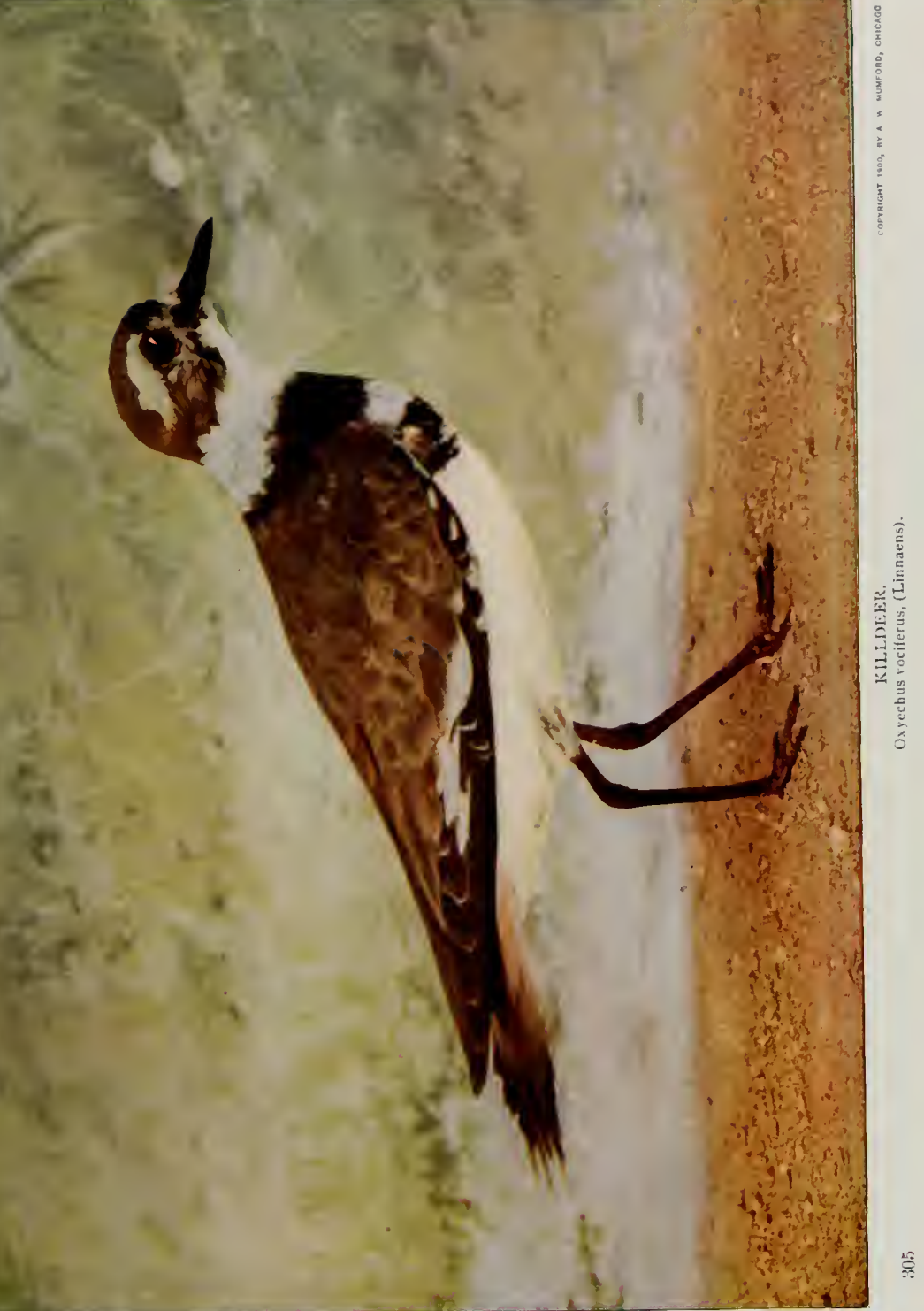





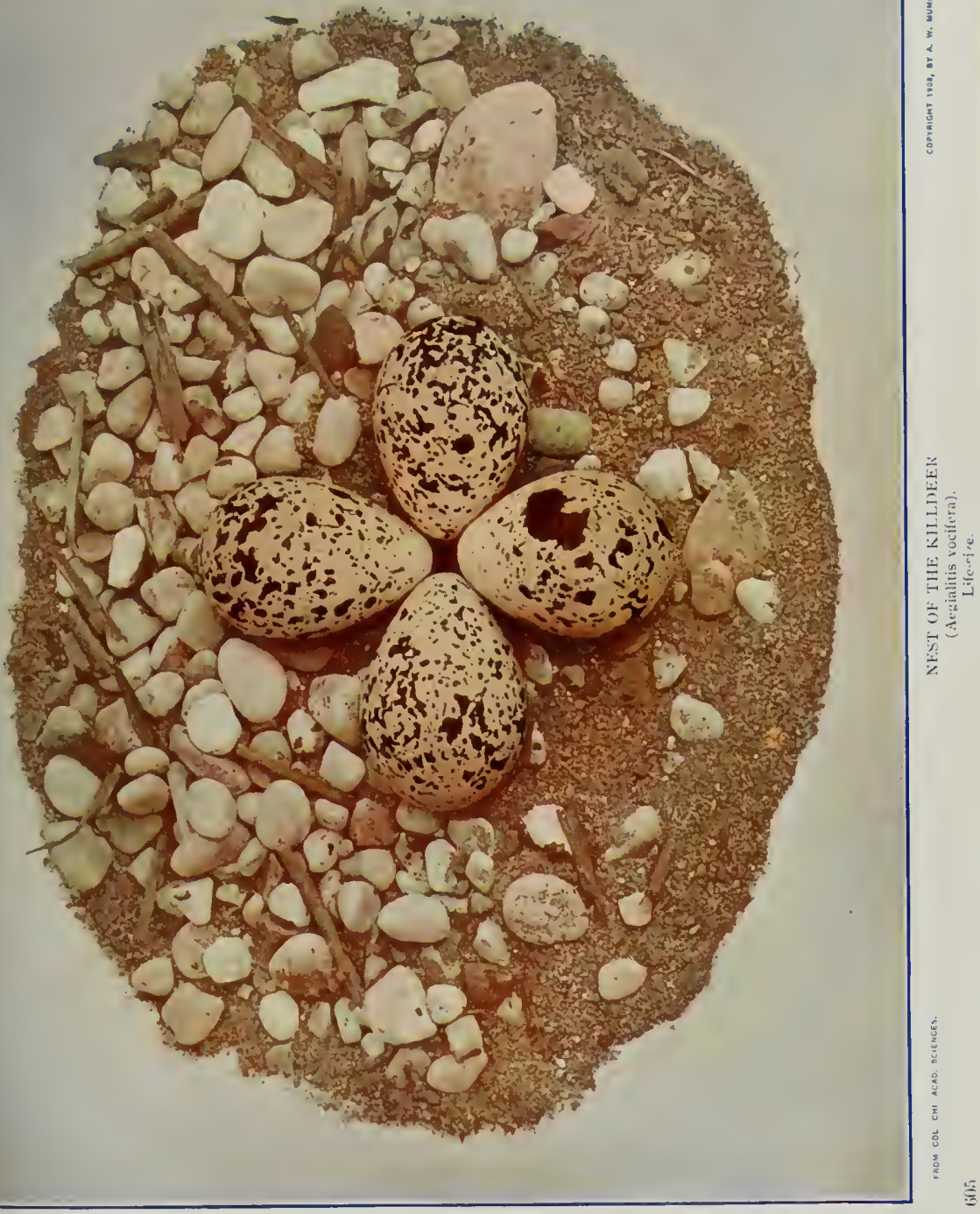



the sandy beach and adjacent flats and uplands. During migration their flight, espccially in the spring, is hurried, direct, and in the night, only stopping to rest and feed during the day, returning, it is said, in a more leisurely manner and largely along the seashore. When on the ground, these birds run about on unbended legs, the bodies in a horizontal position, and heads drawn down. While sleeping or resting they usually sit or stand on one leg.

The flight of a flock of Golden Plovers is described by Goss as swift and strong, sweeping over the prairies in a compact, wavy form, at times skimming close to the ground, then high in the air - an ever-changing, circling course, whistling as they go, and on alighting raising their wings until the tips nearly touch, then slowly folding them back, a habit which is quite common with them as they move about the ground.

Plovers eat grasshoppers, beetles, and many forms of insect life; small berries are also a part of their diet.

The eggs are deposited the latter part of May, in a small depression among the moss and dried grass of a small knoll, and at times a slight structure is made of dried grass. Four eggs are laid, of a pale yellowish ground color, with very dark, well-defined umber brown spots scattered profusely over the shell.

\section{KILLDEER}

By far the commonest of American plovers, it breeds throughout the entire United States and most of Canada, and winters from the Gulf States to northern South America. A suspicious, restless, noisy, uneasy bird, always on 
the alert, it runs and flies rapidly. It inhabits the shores, beaches, and margins of both fresh and salt water.

'The food consists of mollusks, insects and their larvæ, largely gathered from the surface of the earth in both damp and dry places.

Plovers are quite cosmopolitan in their range, and this species has been recorded on either hemisphere. Thousands of miles are covered annually in passing from its Northern breeding range to the southern parts of South America. Mariners have reported small groups of plovers, sandpipers, and phalaropes resting upon the ocean hundreds of miles from land.

Cornfields and waste land are the areas occupied by the killdeer while breeding. Two broods are frequently reared in a season; the first setting hatches early in May, and four more eggs are laid late in July.

I have four eggs taken June 21, 1903, from a cornfield within the city limits of Chicago. The eggs are usually deposited in a slight cavity lined with pebbles which harmonize remarkably with the dull blotched egg.

\section{THE RING PLOVER *}

In their habits the plovers are usually active; they run and fly with equal facility, and though they rarely attempt to swim, are not altogether unsuccessful in that particular.

The Semipalnated Ring Plover utters a plaintive whistle, and during the nesting season can produce a few connected pleasing notes. The three or four pear-shaped, variegated eggs are deposited in a slight hollow in the 


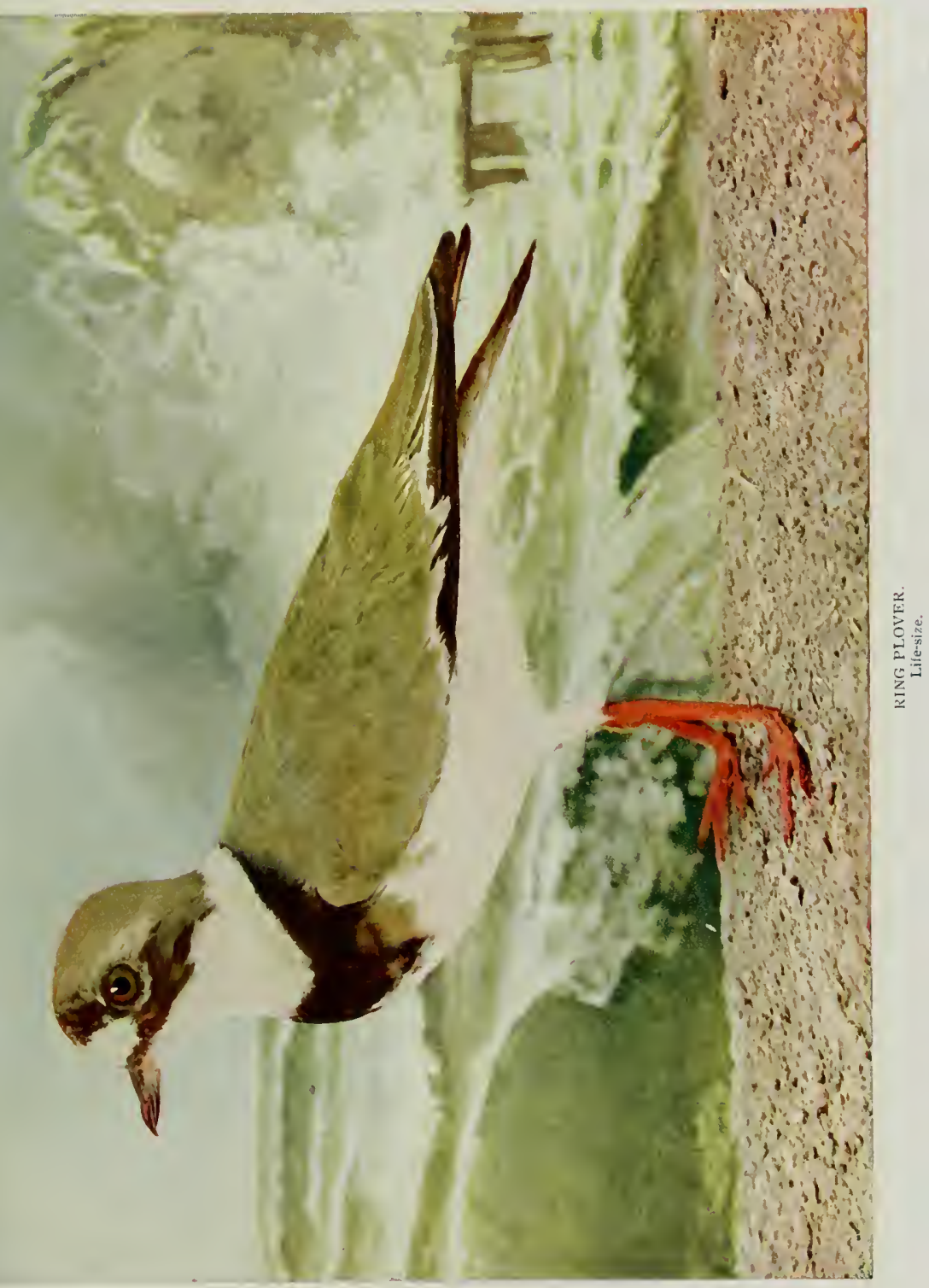





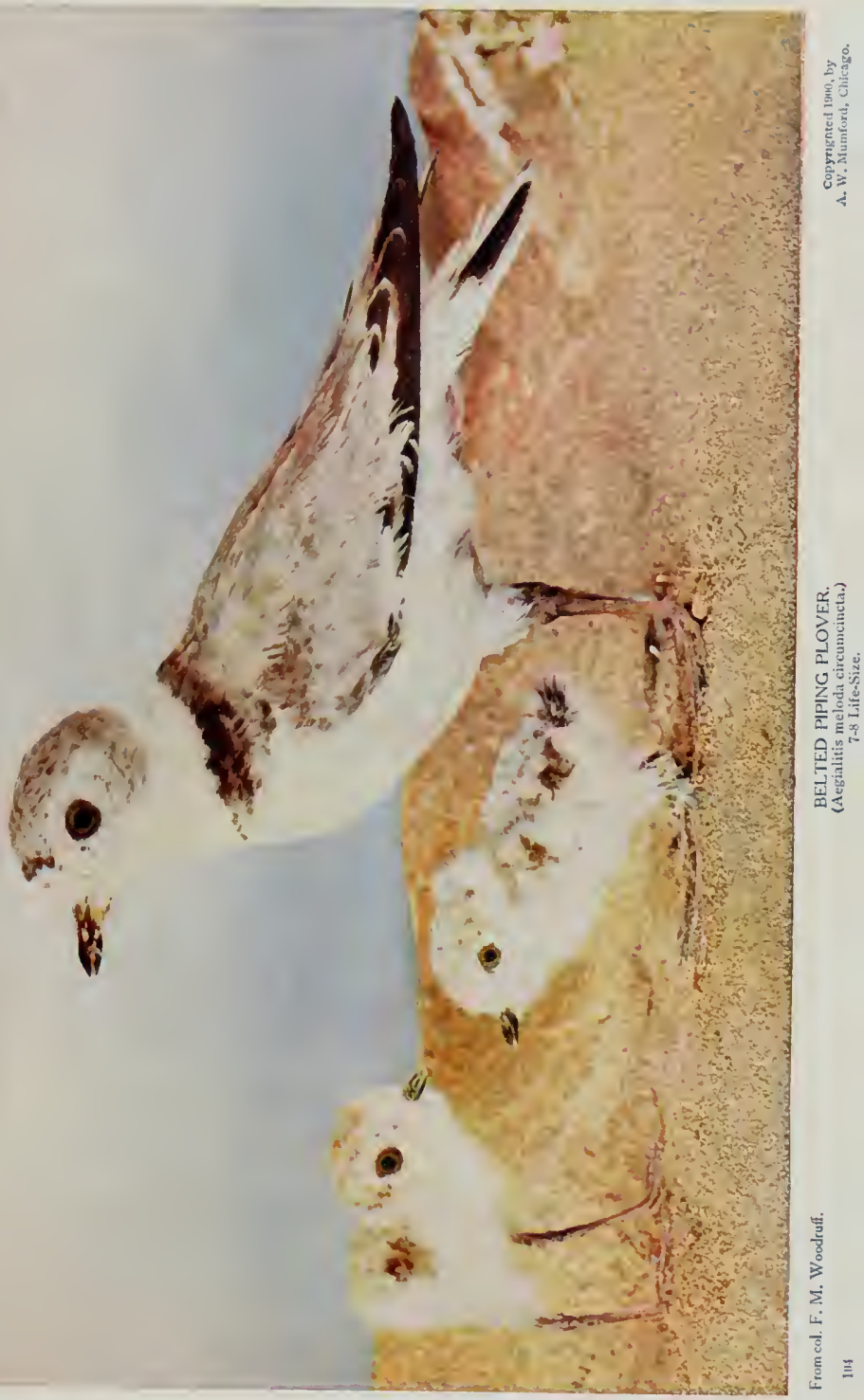



ground, in which a few blades of grass are occasionally placed. Both parents assist in rearing the young. Worms, small quadrupeds, and insects constitute their food. Their flesh is regarded as a delicacy, and they are therefore objects of great attraction to the sportsman, although they often render themselves extremely troublesome by uttering their shrill cry and thus warning their feathered companions of the approach of danger. From this habit they lave received the name of "tell-tales."

The American Ring Plorer nests as far north as Labrador, and is common on our shores from August to October, after which it migrates southward. Some are stationary in the Southern States. It is often called the ring plover, and has been supposed to be identical with the European ringed plover.

It is one of the commonest of shore birds. It is found along the beaches and is easily identified by the complete neck ring, which upon dark, and dark upon light. Like the sandpipers, the plovers dance along the shore in rhythm with the wavelets, leaving sharp half-webbed footprints on the wet sand. 'Though usually found along the seashore, Samuels says that on their arrival in spring, small flocks follow the courses of large rivers, like the Connecticut.

\section{PIPING PLOVER}

These retiring birds are very local in their range, but occur at irregular intervals along the beaches and on the islands in the Great Lakes region, west to several other large inland bodies. Devil's Lake, North Dakota, and 
Lake Manitoba, Canada, are frequented by this retiring shore bird. Along the Atlantic Coast from Long Island to the Gulf of St. Lawrence, the birds breed among the debris not far above high-water mark. They winter from Florida southward.

The dark band across the breast is more distinct in some species; hence, for a time, scientists divided the birds, calling the eastern forms the piping plover, and the birds taken west of Lake Erie were described as the belted piping plover. Further investigation developed the fact that the range had practically nothing to do with the distinctiveness of the band on the breast, and the birds are all now recognized as the piping plover.

May 30, 1911, we plodded through the sand among the scant evergreen and sand dunes overlooking the south shore of Lake Michigan, a desolate country, too clean and barren of plant and animal life to satisfy many birds. Small colonies of bank swallows were perforating the little perpendicular bluffs, and about the old pine stubs the white-bellied swallows hovered, while occasionally a herring gull patrolled the beach, as a scarenger. A metallic peep came from the base of a sand dume, and with field glasses I carefully scanned the vast waste. A piping plover flitted across the beach, circling over the pebbles and driftwood, and squatted in the center of a little elevation just back of a sheltering log. As I approached the sitting bird, she rapidly ran in a wide circle, joining her mate. Both were solicitous and approached me in a distressed attitude, plaintively protesting at my intrusion, by calling in their mellow notes which were so in keeping with the bleak surroundings. 


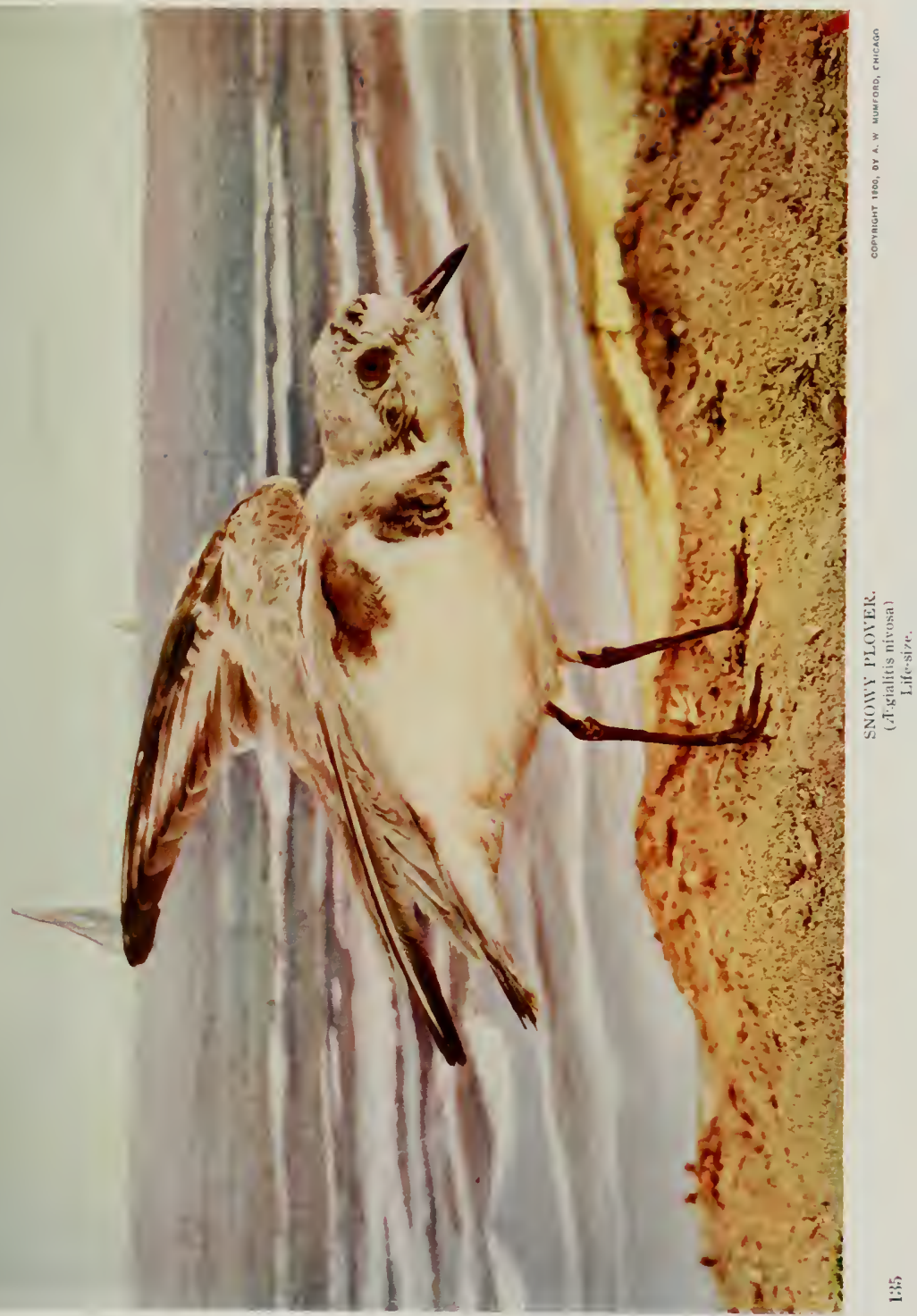



The eggs rested in a bare hollow of the whitc sand, with their four points together, dainty little clay-colored shells, minutely dotted with purple and dark brown.

\section{THE SNOWY PLOVER *}

The Snowy Plover is found chiefly west of the Rocky Mountains, and is a constant resident along the California coast. It nests along the sandy beaches of the ocean. Mr. N. S. Goss found it nesting on the salt plains along the Cimarron River in the Indian Territory, the northern limits of which extend into southwestern Kansas. These birds are described as being very much lighter in color than those of California. Four eggs are usually laid, in ground color, pale buff or clay color, with blackish-brown markings. Mr. Cory says the nest is a mere depression in the sand. He says also that the snowy plover is found in winter in many of the Gulf States, and is not uncommon in northwestern Florida.

When the female snowy plover is disturbed on the nest, she will run over the sand with outstretched wings and distressing gait, and endeavor to lead the trespasser away from it. It sometimes utters a peculiar cry, but is usually silent. The food of these birds consists of various minute forms of life. They are similar in actions to the semipalmated and fully as silent. Indeed, they are rarely heard to utter a note except as the young are approached - when they are very demonstrative - or when suddenly flushed, which, in the nesting seasons, is a very rare thing, as they prefer to escape by running, dodging, and squat- 
ting the moment they think they are out of danger, in hopes you will pass without seeing them, as the sandy lands they inhabit closely resemble their plumage in color.

The first discovery of these interesting birds east of Great Salt Lake was in June, 1886. A nest was found which contained three eggs - a full set. It was a mere depression worked out in the sand to fit the body. It was without lining, and had nothing near to shelter or hide it from view.

\section{THE TURNSTONE*}

This small plover-like bird is found on the seacoast of nearly all countries; in America, from Greenland and Alaska to Chili and Brazil; more or less common in the interior along the shores of the Great Lakes and larger rivers.

It is generally found in company with flocks of the smaller species of sandpipers, its boldly marked plumage contrasting with surroundings, while the sandpipers mingle with the sands and unless revealed by some abrupt movement can liardly be seen at a little distance.

It is found on smooth, sandy beaches, though more commonly about the base of rocky cliffs and cones. The eggs of horseshoe crabs are its particular delight.

In the nesting season the Turnstone is widely distributed throughout the northern portions of both continents, and wanders southward along the seacoasts of all countries. The nest is a hollow scratched in the earth, and is lined with bits of grass.

The turnstone is known by various names: "Brant 


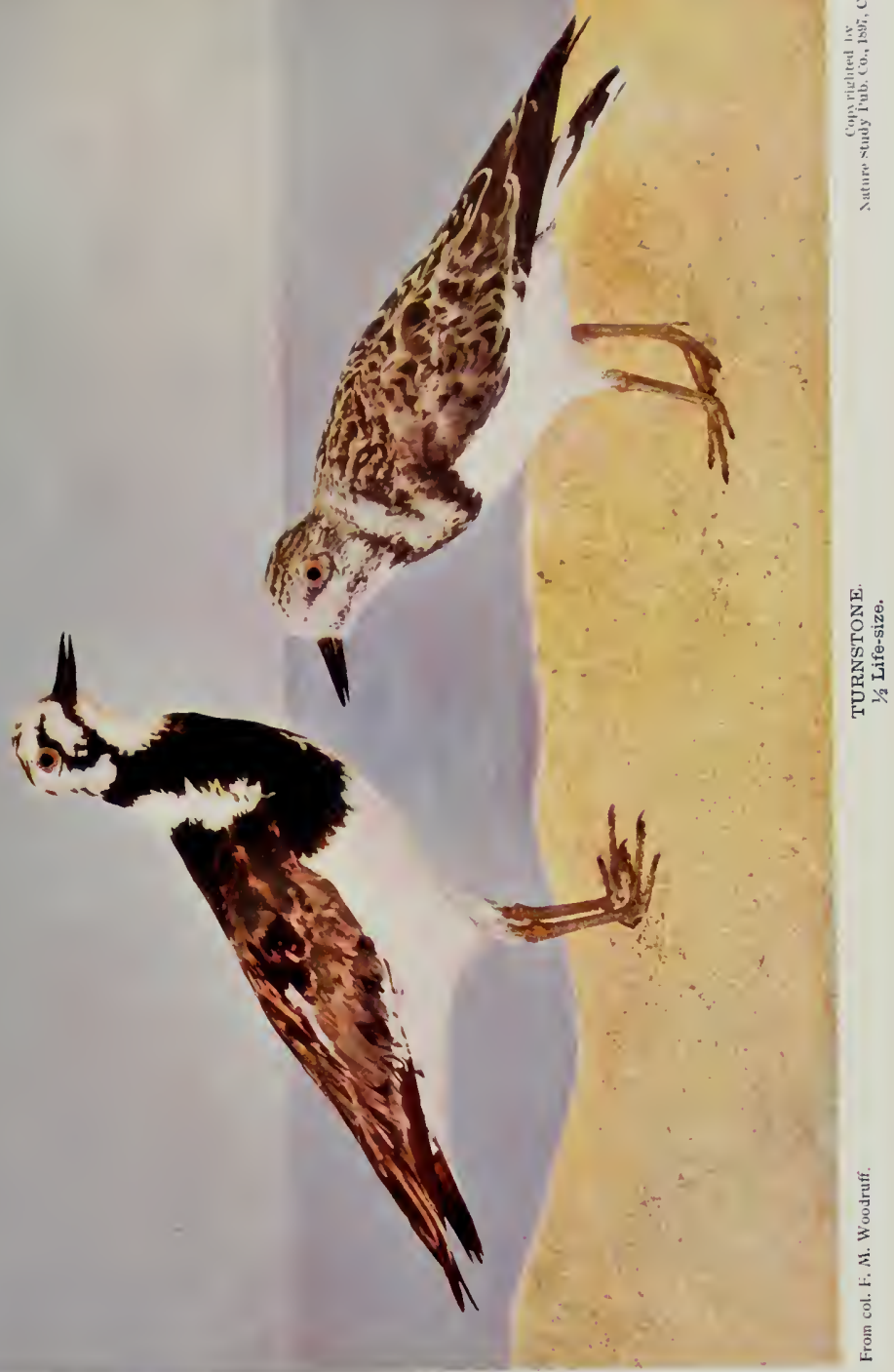



Bird," "Bead Bird," "Horse-foot Snipe," "Sand-runner," "Calico-back," "Chicaric," and "Chickling." 'The two latter names have reference to its rasping notes, "calicoback" to the variegated plumage of the upper parts.

In summer the adults are oddly pied above with black, white, brown, and chestnut-red, but the red is totally wanting in winter. They differ from the true plovers in the well developed hind toe and the strong claws, but chiefly in the more robust feet, without the trace of web between the toes.

The eggs are greenish-drab in color, spotted, blotched, and dotted irregularly and thickly with yellowish and umber brown. The eggs are two or four, abruptly pyriform in shape. 



\section{CHAPTER IX}

QUAIL, GROUSE, ETC.

OF THE two hundred species of the grouse family, sixty only are found in the new world. With few exceptions, these birds are not migratory. After nesting they gather in covies or bevies-birds of one family, which in some species unite and form large flocks. They are usually resident throughout the year where found.

While usually terrestrial, some use the trees when flushed. Obtaining their food from the ground, they are scratchers, with strong legs and feet and well developed nails. The plumage is of dull colors to harmonize with the grass surroundings. These game birds seek safety by hiding rather than by their rapid flight, which starts with a whirr as they beat the air with their short, stiff wings. Protective coloration is marked.

Of the pigeons and doves, twelve species only are found in North America. Some of these are arboreal, others are terrestrial; some are found in forests, others in prairies; some nest in colonies, others in pairs, but they usually flock after the breeding season. When drinking they do not raise the head as do other birds, but keep the bill immersed until they have finished drinking. The young are born naked, and fed by regurgitation. They are less prolific than other game birds, and yet the wild pigeons were formerly our most numerous bird. The mourning 
dove is the most common representative in eastern North America.

\section{BOB-WHITE}

The Bob-white, often called quail or partridge, is a resident of eastern and middle North America. The male is handsomely mottled with a shade of soft reddish-brown almost approacling old rose; black and white is conspicuous in various places. In the female, colors are more somber, the white being replaced with buff. The bob-white, like most ground birds, is well protected by color resemblance to the surroundings. The original name quail applies to an Oriental bird mentioned in the Bible.

The clear, distinct call notes of the male give rise to the name "bob-white." The three-syllabled whistle sounds like "Me-bob-white," with particular emphasis on the last syllable. The first syllable is rather faint, and at a distance one hears nothing but the name "bob-white." As a call note during the fall and winter, when the birds are flocking, the syllable "me" is used by the different birds in reorganizing the little band which has become scattered.

The bob-white is resident in the same locality and, for mutual protection, remain in small flocks of from ten to thirty from September until early April.

Their method of "roosting" is practical and picturesque. During the short days of winter, when the snow is in the woods, I have frequently tracked the little fellows to the edge of a brush pile, where the flock is encamped for the night. They cluster in a circle, the tails together, each bird facing in a different direction. This formation con- 

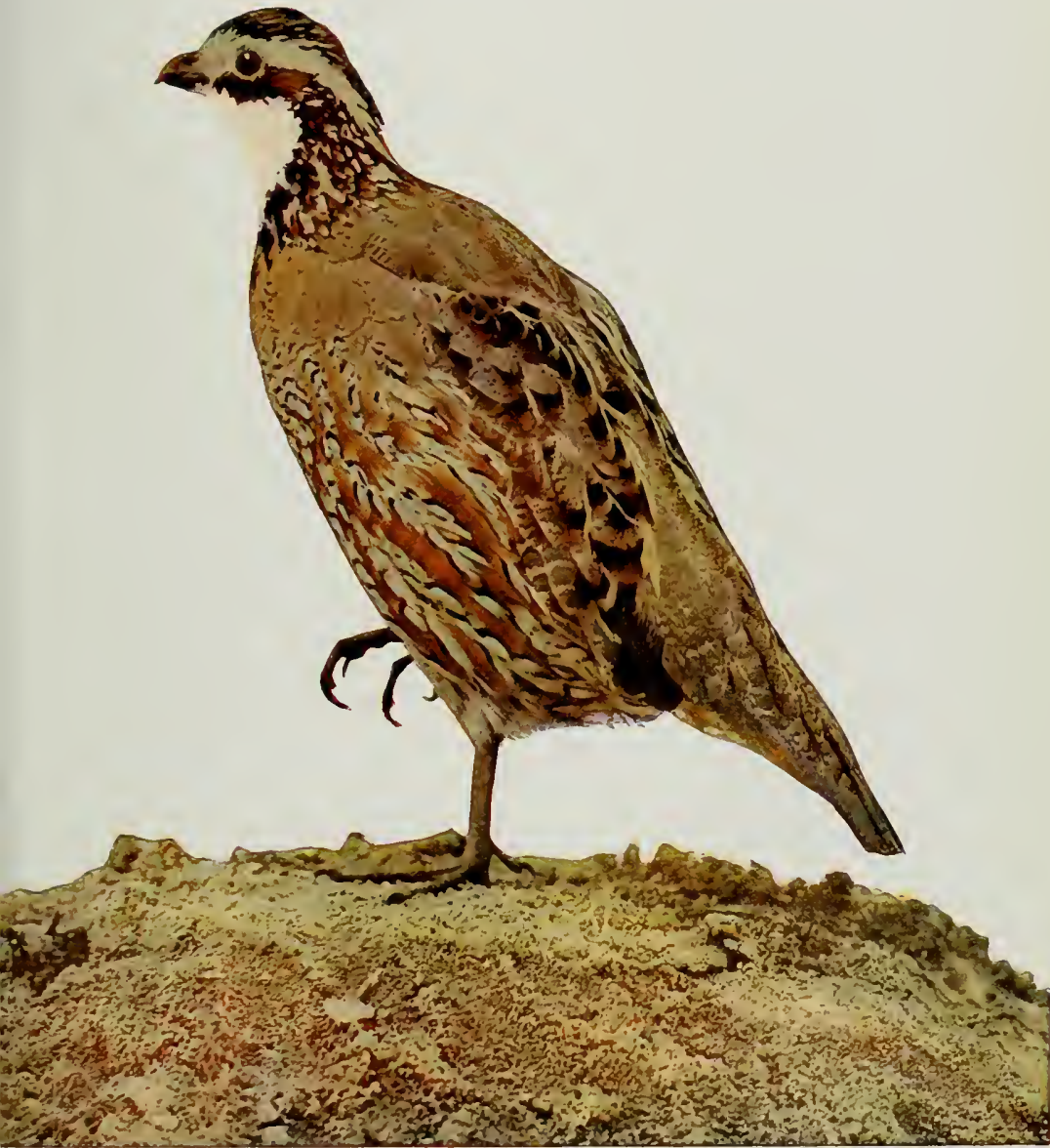

serves the heat of the body and gives the best protection from their natural enemies, as there is a guard on the lookout at every point of the compass.

The food of the quails is both insectivorous and regetable. They destroy great numbers of insects, including chinch bugs, beetles, grasshoppers, the seeds of detrimental weeds and grasses, with some berries and grains. The destructive hessian fly is the natural food for the young, as the mother leads them into a wheatfield if possible. Bobwhites should be fed in bad weather in the winter, especially at time of deep snows or sleet, and should be protected by law throughout the year.

A disturbed flock of bob-white spring from the ground with startling wing-beats, each bird pursuing a different course, alternately flapping their wings and sailing and dropping into cover within a few seconds. They run rapidly after alighting, and soon squat close to the ground in an attempt to escape detection. Assembling call notes then bring the flock together. These birds are not polygamous, like many of our game birds, but remain in pairs through the breeding season.

The nests are placed in fields, orchards, and pastures. A thick clump or tussock of grass with an opening at the side is used by the birds as a nesting site. A little hollow is scratched in the earth, and dry grass is about the only thing that is used in constructing the nest. From eight to twenty pure white eggs are laid. Unlike the eggs of any other partridge or grouse, they are pure white when laid, though dampness frequently stains the shells before the young are hatched. 
The birds thrive in cultivated sections and are practically domesticated, but frequently desert a nest of eggs when the sitting bird has been flushed or nest disturbed. Both male and female assist in the duties of incubation, which trait is uncommon among gallinaceous birds. Two broods are frequently reared in a season; the first setting is begun in April, and another nest of eggs may often be found late in June, or as far into the summer as early August. The young run about as soon as hatched.

The Florida bob-white is a sub-species confined to the southeastern part of the United States. It is somewhat darker in plumage. Another variation in plumage, known as the Texas bob-white, may be found inhabiting Texas and New Mexico. These birds are slightly smaller in size, and the peculiar old rose tint found in the plumage of our common bob-white is replaced by gray in this species.

\section{THE MOUNTAIN PARTRIDGE*}

This, one of the most beautiful of the partridges, is much larger and handsomer than bob-white, though perhaps not so interesting or attractive as a game bird. The pretty plumes are noticeable in the chick just from the egg, in the form of a little tuft of down, and their growth is gradual until the perfect plumage of the adult is obtained.

The Mountain Partridge is found breeding along the Pacific Coast region from California north into Washington. According to the observer Emerson, it is found nesting in the higher mountain ranges, not below four thousand 

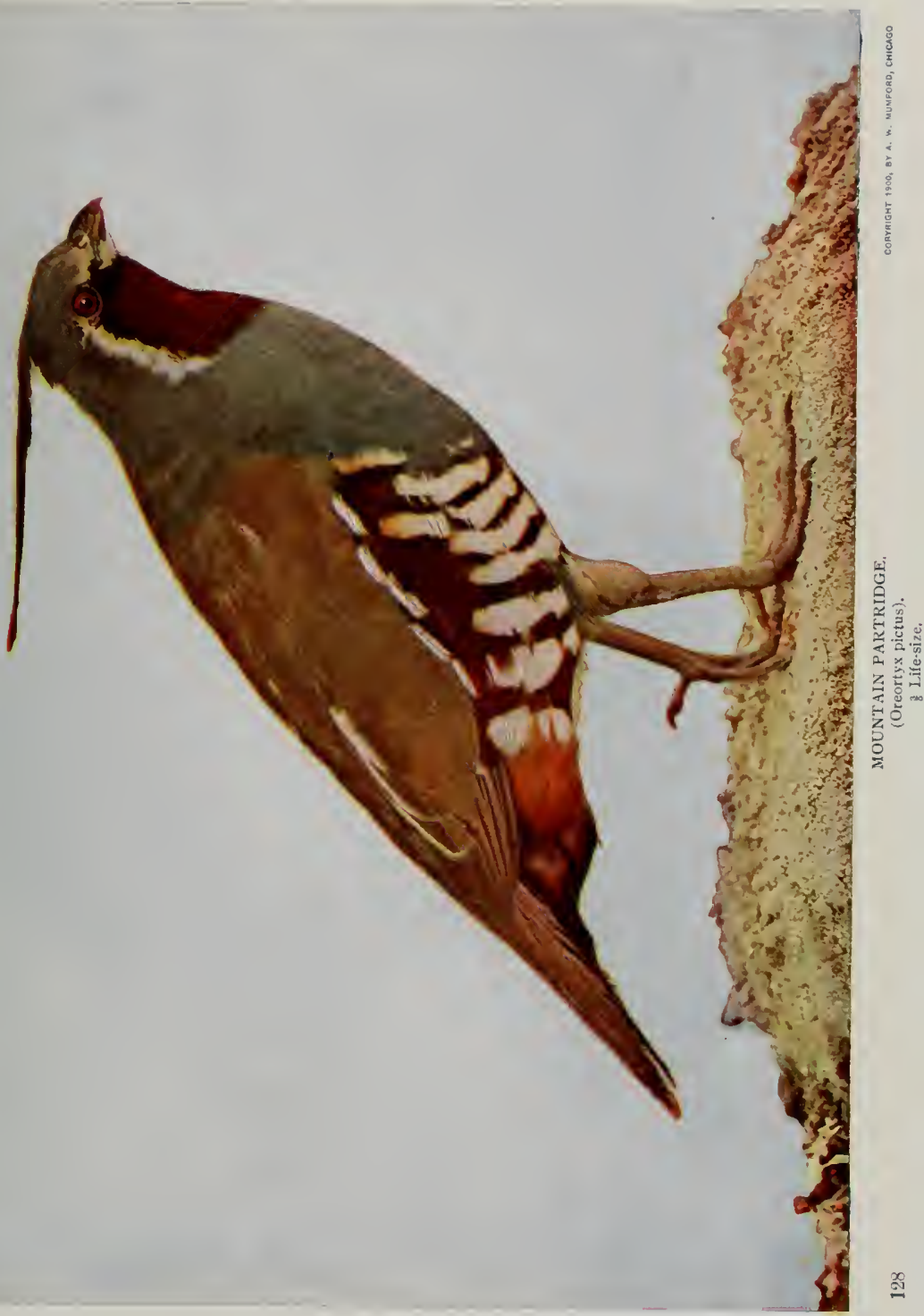



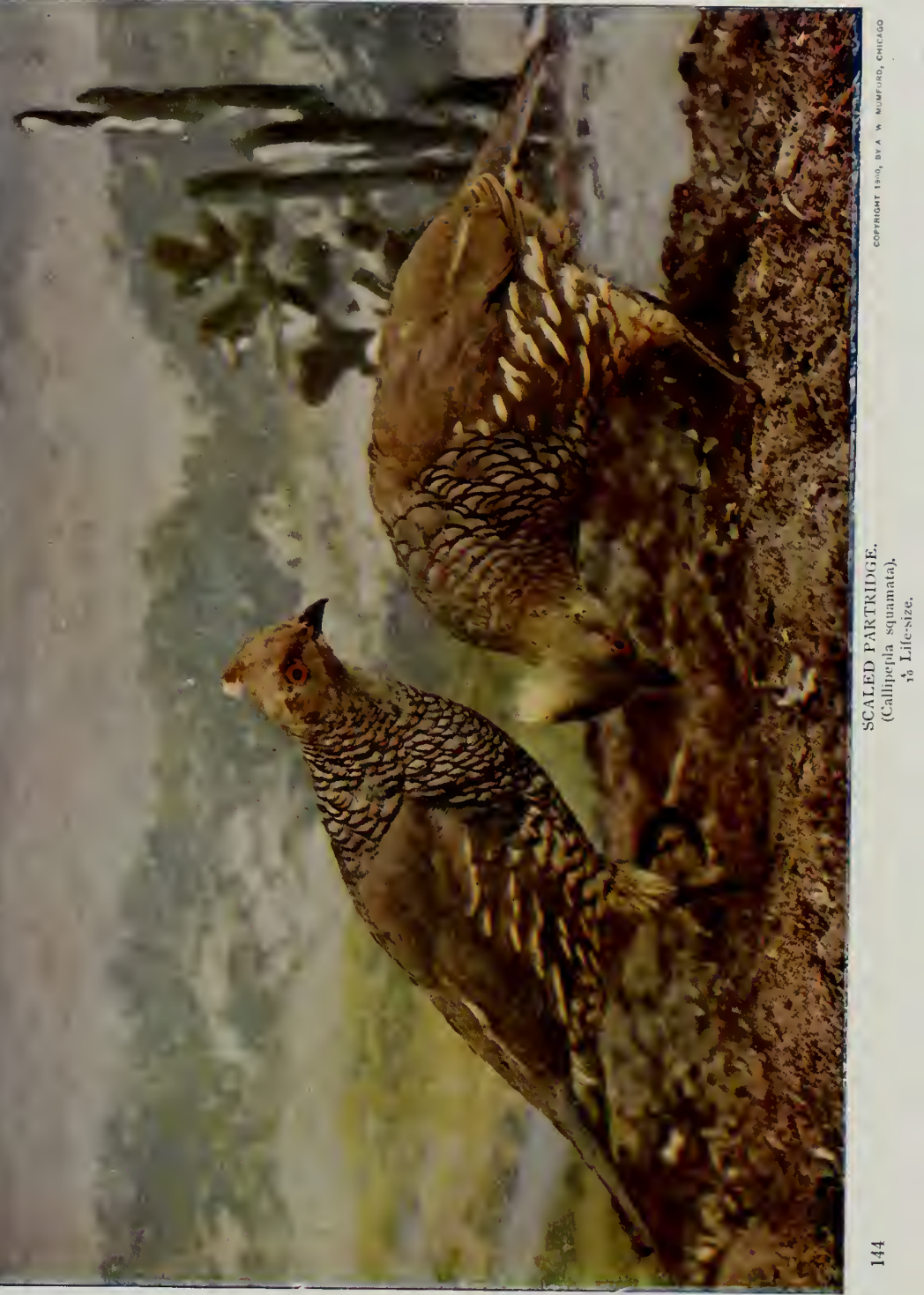



feet. In some portions of Oregon it is very abundant, and would be sought for by the sportsman with great assiduity, were the regions that it inhabits more accessible. As it is, it is not only hard to find but very difficult to secure when once flushed, hiding easily from the dogs, which become discouraged by repeated unsuccessful efforts to find it.

The mountain partridge deposits its eggs on the ground, on a bed of dead leaves, under a bush or tuft of grass or weeds. Its habits are exceedingly like those of the bobwhite. From six to twelve eggs are laid, of a cream color, with a reddish tint. They have been described as miniatures of those of the ruffed grouse, only distinguishable by their smaller size.

This partridge will usually run before the dog, is flushed only with much trouble, and often takes to the trees after being started. California is comparatively destitute of wood except on inaccessible mountain sites and cañons, localities preferred by these birds. It is not known to descend to the valleys.

\section{THE SCALED PARTRIDGE *}

Throughout northwestern Mexico and the border of the United States from western Texas to New Mexico and southern Arizona, this handsome partridge, called the Blue Quail, is found in abundance, especially on the dry mesas of the San Pedro slope of the Santa Catalina mountains, up to an altitude of three thousand five hundred feet. In Arizona they are found in flocks of from six to ten, sometimes more, in barren places, miles away from water. 
The blue quail, like all the other Western and Southwestern species, prefers to trust to safety to its powers of running, rather than those of flight. The great trouble is to start them from the ground.

A slight depression under a bush serves for the nest of this bird, which is generally lined with a few coarse grasses. Complete sets of eggs have been found as early as April 25. The eggs are extremely thick-shelled, of a buffy-white or cream color. The number laid ranges from eight to sixteen.

The habits of this quail do not differ greatly from those of bob-white, though they have not been fully studied, and the species is of less extensive distribution.

\section{GAMBEL'S PARTRIDGE*}

Gambel's Partridge, of which comparatively little is known, is a characteristic game bird of Arizona and New Mexico, of rare beauty, and with habits similar to others of the species, of which there are about two hundred. Mr. W. E. D. Scott found the species distributed throughout the entire Catalina region in Arizona below an altitude of five thousand feet. The bird is also known as the Arizona Quail.

The nest is made in a depression in the ground, sometimes without any lining. From eight to sixteen eggs are laid. They are most beautifully marked on a creamywhite ground with scattered spots and blotches of old gold, and sometimes light drab and chestnut red. In some specimens the gold coloring is so pronounced that it strongly suggests to the imagination that this quail feeds upon the 
(15)

(1)

ing

(1)

(1)

(1)

(1) 3.5. 3.5.

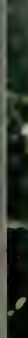

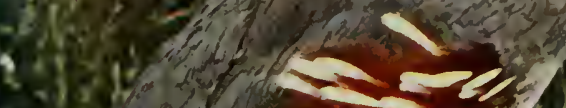
+ 50 In $x^{2}$ n. 10..... cotcris

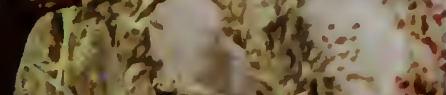

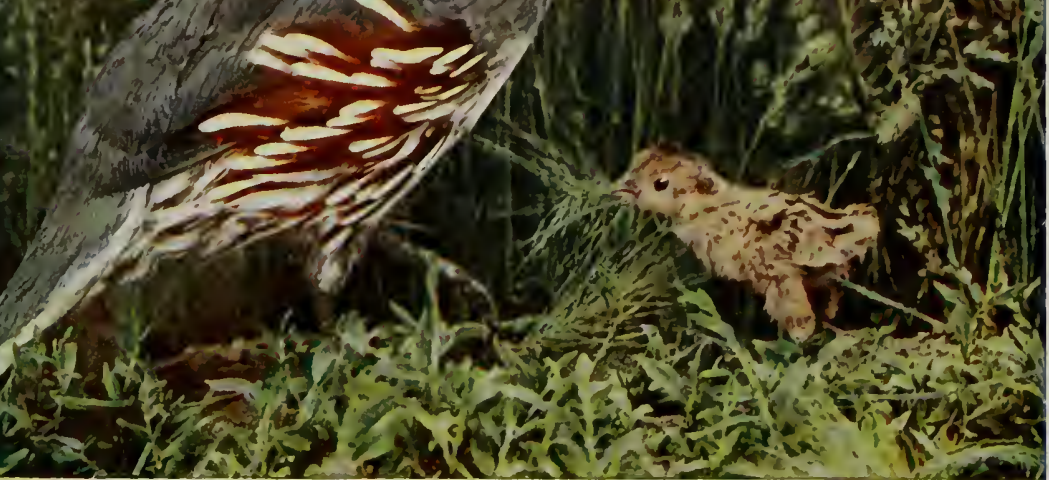





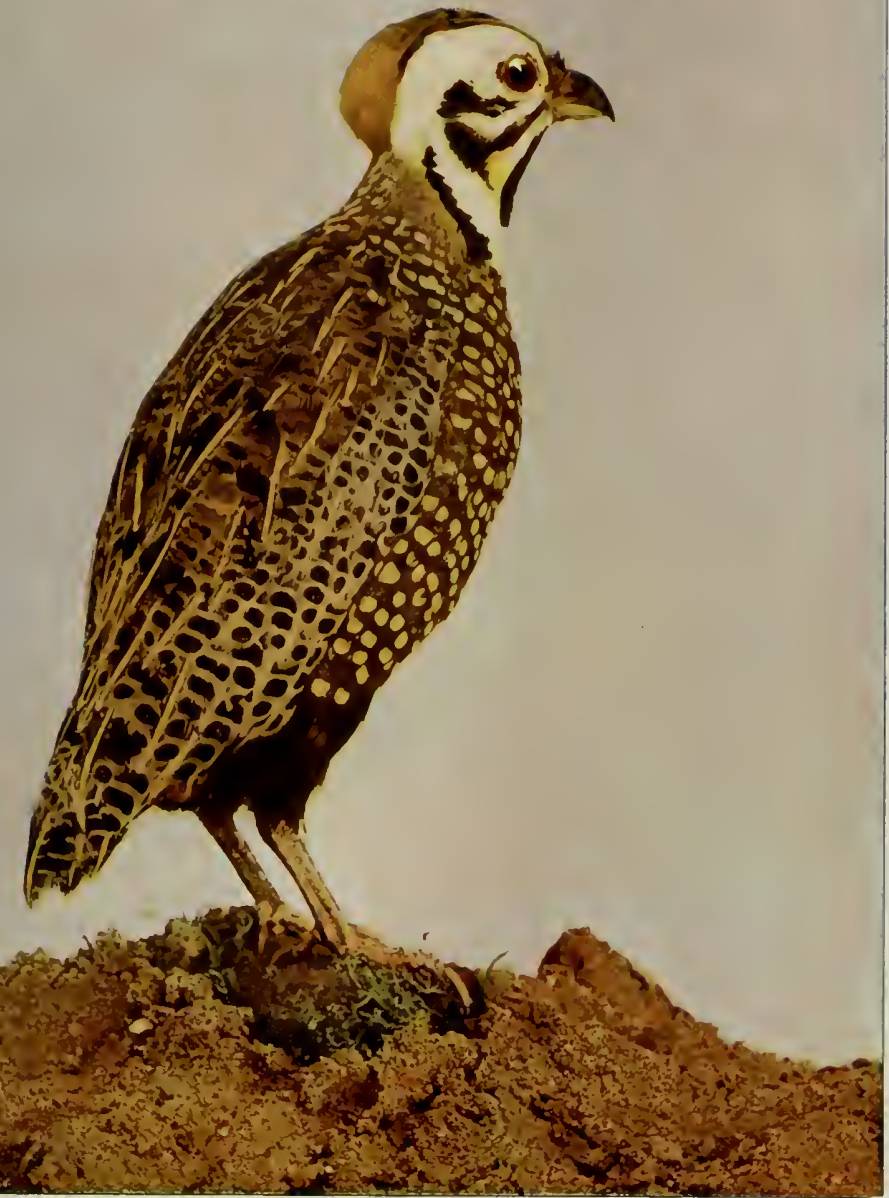



grains of the precious metal which characterizes its home, and that the pigment is imparted to the eggs.

After the nesting season these birds commonly gather in "coveys" or bevies, usually composed of the members of but one family. As a rule they are terrestrial, but may take to trees when flushed. They are game birds par excellence, and, says Chapman, trusting to the concealment afforded by their dull colors, attempt to avoid detection by hiding rather than by flying. The flight is rapid and accompanied by a startling whirr, caused by the quick strokes of their small, concave, stiff-feathered wings. They roost on the ground, tail to tail, with heads pointing outward, "a bunch of closely huddled forms - a living bomb, whose explosion is scarcely less startling than that of dynamite manufacture."

The partridge is on all hands admitted to be wholly harmless and at times beneficial to the agriculturist. It is an undoubted fact that it thrives with the highest system of cultivation, and the lands that are the most carefully tilled, and bear the greatest quantity of grain and green crops, generally produce the greatest number of partridges.

\section{THE MASSENA PARTRIDGE*}

This beautiful species is said to be by far the most gentle and unsuspicious of our quails, and will permit a very close approach by man, showing little or no fear of what most animals know so well to be their most deadly enemy. While feeding they keep close together, and constantly utter a soft clucking note, as though talking to one another. 
This species is about the size of the Eastern variety. Its head is ornamented with a beautifully full, soft occipital crest. The head of the male is singularly striped with black and white. The female is smaller and is quite different in color, but may be recognized by the generic characters. The tail is short and full, and the claws rery large.

The quail makes a simple nest on the ground, under the edge of some old log, or in the thick grass on the prairie, lined with soft and well-dried grass and a few feathers. From fifteen to twenty-four white eggs are laid. The female sits three weeks. The young brood, as soon as they are fairly out of the shell, leare the nest and seem abundantly strong to follow the parent, though they are no bigger than the end of one's thumb, corered with down. The massena quail is an inhabitant of the Western and Southwestern States.

\section{THE DUSKY GROUSE *}

Under various names, as Blue Grouse, Grey Grouse, Mountain Grouse, Pine Grouse, and Fool-hen, this species, which is one of the finest birds of its family is geographically distributed chiefly throughout the wooded and especially the erergreen regions of the RockT Mountains to the Pacific and northward into British America. Its food and habits are similar to those of the ruffed grouse. Its food consists of insects and the berries and seeds of the pine cone, the leares of the pines, and the buds of trees. It has also the same habits of budding in the trees during deep snors. In the blue grouse, howerer, this habit of remaining and feeding in the trees is more decided and constant, 


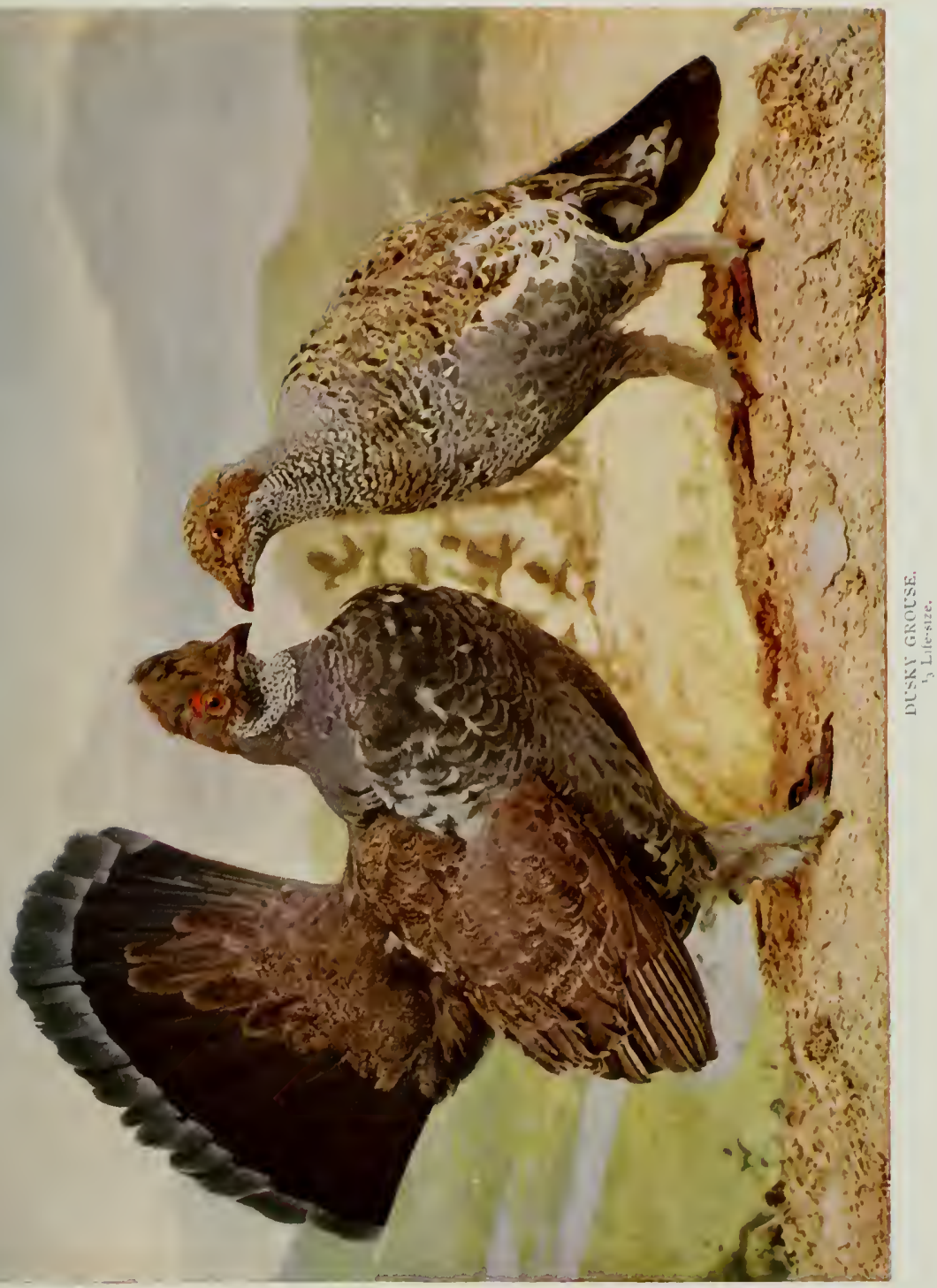





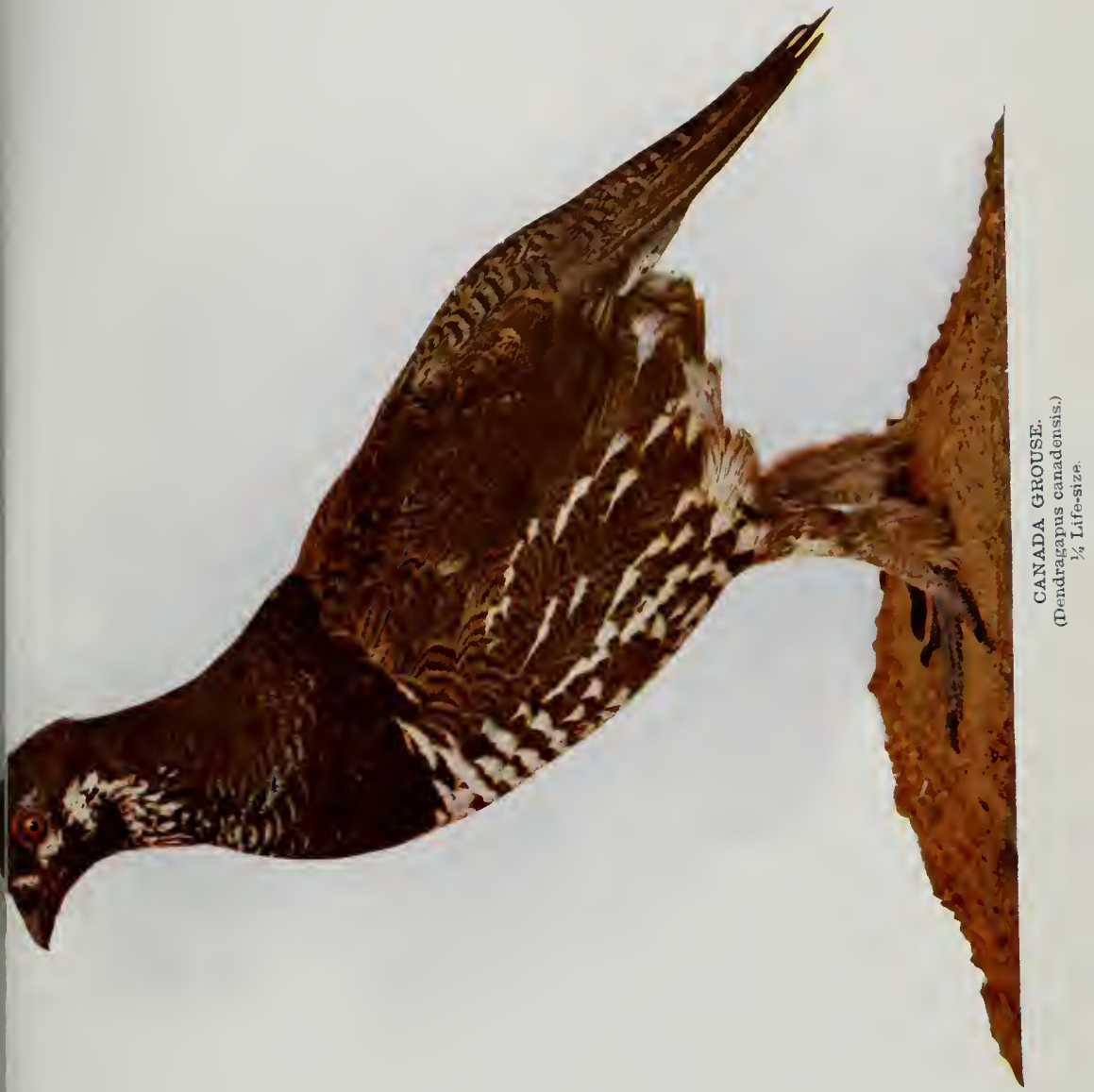



and in winter they will fly from tree to tree, and often there are plenty in the pines, when not a track can be found in the snow.

The size of the dusky grouse is nearly twice that of the ruffed grouse, a full-grown bird weighing from three to four pounds. The feathers are very thick, and it seems fitly dressed to endure the vigor of its habitat, which is in the Rocky Mountain and Sierra Nevada country only, and in the pine forests from five to ten thousand feet above the level of the sea. The latter height is generally about the snow line in these regions. Although the weather in the mountains is often mild and pleasant in winter, and especially healthy and agreeable from the dryness and purity of the atmosphere, yet the cold is sometimes intense.

This grouse nests on the ground, often under shelter of a hollow $\log$ or projecting rock, with merely a few pine needles scratched together. From eight to fifteen eggs are laid, of buff or cream color, marked all over with round spots of umber-brown.

\section{THE CANADA GROUSE*}

The Canada Grouse, also called the Spruce Partridge, frequents the evergreen forests and swamps and the shrubby areas of British America east of the Rocky Mountains, and in Alaska it is a resident of the Pacific Coast. In its southern flights it seldom passes beyond the latitude of the northern portion of New England and Minnesota.

The Canada grouse, like all the related species, is a bird of rapid flight. The feathers of their small wings are stiff, causing a whirring sound during flight. The male 
during the mating season gives a great deal of attention to his appearance. He is quite black in general color and more or less barred with white underneath and above with gray or reddish-brown. The female is not quite as large as the male, and is not as dark in color. Above the eye of the male there is a small area of bare skin, which is a bright vermilion color.

The nest, consisting of loosely arranged blades of grass and a few stalks and twigs, is built by the hen on a slight elevation of ground, usually under the low branches of a spruce tree.

The number of eggs varies greatly. Mr. Ridgway says that they vary in number from nine to sixteen. The eggs also vary greatly in color from a pale, creamy buff through various shades to brownish-buff, and are irregularly spotted with a deeper brown, though occasionally they are spotless.

During the spring and summer months the food of the Canada grouse consists very largely of the berries of plants belonging to the heath family, such as the blueberry, the huckleberry, and the barberry, as well as the tender buds of the spruce. In the winter it feeds almost entirely on these buds and the needle-like leaves of the spruce, the fir, or the tamarack trees. At times they seem to show a preference for certain trees and will nearly strip the foliage from them.

\section{RUFFED GROUSE}

Among New England sportsmen the Ruffed Grouse, often called Partridge, is the farorite game bird. The true ruffed grouse occurs in New York, westward through the 


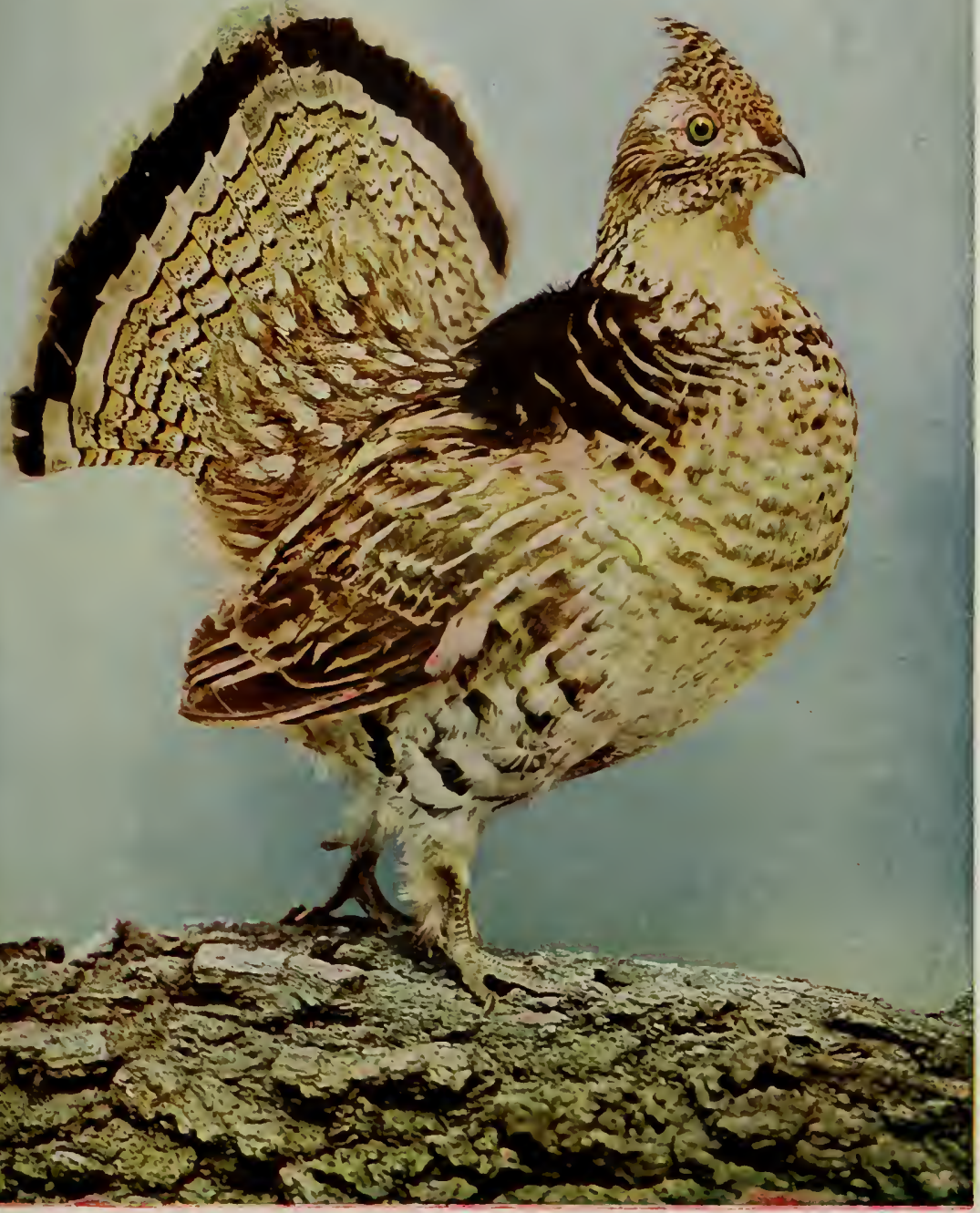



United States to the Rocky Mountains, becoming rather scarce beyond the states bordering the Mississippi. Maine and the White and Green mountain regions nortliward into Quebec is the home of the Canada ruffed grouse, a subspecies slightly larger. Two other forms occur in the West; the Oregon ruffed grouse inhabits the Pacific Coast and the gray ruffed grouse is found in the Northwest east of the Sierras and within the Rocky Mountain region.

One of the most marvelous examples of adaptability to climatic conditions is shown in the feet of the ruffed grouse. The birds are resident the year around wherever found, and, requiring snow shoes for winter, the toes in fall are equipped with fine, stiff, projecting feathers, extending horizontally on either side of the toes, resembling a doubletoothed comb in form. This added foot surface enables the bird to walk with ease on the surface of the snow. The projections drop off at the approach of warm weather.

Birds give vent to their emotion during the mating and breeding season by various vocal sounds, many of which are highly musical. Some species produce what is known as wind music, such as the boom of the nighthawks, caused by the birds swooping earthward from a height, allowing the air to pass through the primaries turned on edge. Of a somewhat similar nature is the "drumming of the grouse"; the bird assumes an attitude similar to a strutting turkey gobbler as from stump or log, with spreading tail, he rapidly beats the sides of his body with the wings, producing a sound like the muffled roll of a drum.

The flight of the partridge is terrific, but of short duration. When flushed by the gunner he seems to have the 
faculty of keeping the trunk of a tree between limself and the enemy. If the birds are disturbed by a prowling animal or untrained dog, they take readily to the lower branches of trees, and will permit a person to walk directly under them without attempting to fly. They are often killed from such perch by unsportsmanlike hunters.

Grouse choose a varied diet-insects, spiders, wild berries, and small fruits; also partaking of grains and freshsprouted vegetable matter.

The nests are usually a hollow in the leaves at the base of a tree or under a fallen branch. From eight to ten creamcolored eggs are laid. The bird sits extremely close, and one may pass within a few feet of the parent bird without disturbing her. The nests are usually near an opening in the woods or on a small incline overlooking a damp or swampy place. The young are piloted about by the mother as soon as they leave the shell. Protective coloration is marked.

\section{THE WILLOW PTARMIGAN}

In summer the Willow Ptarmigan is distributed throughout Arctic America. It breeds abundantly in the valleys of the Rocky Mountains, on the Barren Grounds, and along the Arctic coasts. The winter dress of this beautiful bird is snow white, with the central tail feathers black tipped with white. In summer the head and neck are yellowish-red, back black, barred rather finely with yellowish-brown and chestnut, although the most of the wings and under parts remain white, as in winter. Large numbers of the willow ptarmigan are said in the winter to shelter in 


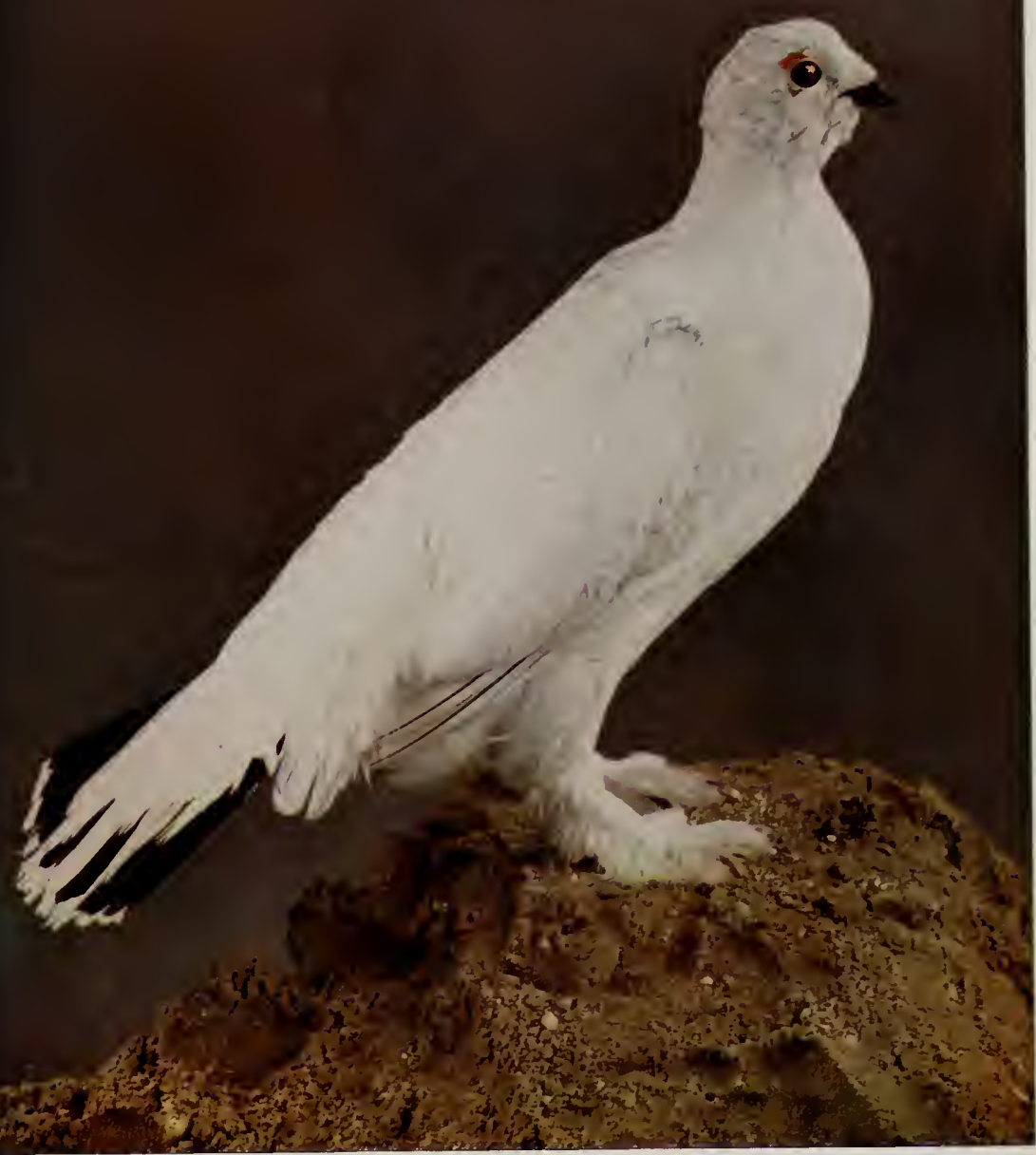



willow thickets and dwarf birches on the banks of lakes and rivers, where they feed on the buds of the smaller shrubs, which forms their principal food at that season. Their favorite resorts in daytime are barren, sandy tracts of land, but they pass the nights in holes in the snow. When pursued by sportsmen or birds of prey they dive in the loose snow and work their way beneath its surface.

The nests are mere depressions in the ground; lined with leaves, hay, and a few feathers from the birds themselves. These birds often occupy the same nest in successive seasons. Ten eggs are usually laid. The eggs have a ground color varying from yellowish-buff to deep chestnut-brown, more or less sprinkled, speckled, spotted, or marbled with rich brown or black.

They are to be distinguished from all other members of the grouse family by the dense feathering of the tarsus and toes, by turning white in winter, and by the possession of only fourteen tail feathers. The bill is very stout and the tail always black. $\quad$ C. C. M.

\section{WHITE-TAILED PTARMIGAN}

Ptarmigan inhabit the colder regions of America and Europe. Their occurrence is in western Canada and in the United States, chiefly in the mountainous regions of Colorado, Montana, Idaho, Oregon, and Washington, where they reach an altitude possessing a decidedly boreal climate. During the winters they sometimes descend into the plains and feed upon wild sprouts and berries.- The winter plumage is pure white, while in spring the feathers are brown 
mottled with gray. Both types of coloration serve to protect the birds from their natural enemies. They range in comparatively open places, and in winter their immaculate feathers enable the birds to move about over the snow without attracting the attention of their natural enemies, eagles, owls, foxes, and other carnivorous creatures. Their summer homes on the mountain ranges are often above the timber line, where nothing but a sparse growth of moss exists. The birds at this season of the year are very difficult to find, owing to the similarity of their plumage to the surrounding rocks and vegetation.

Ptarmigan are seldom hunted with dog or gun, and consequently are approachable, often exhibiting no more fear of a man than does the ordinary barnyard fowl. The whitetailed ptarmigan inhabits the Rocky Mountain and Sierra Nevada ranges from Colorado northward to Alberta and British Columbia.

Naturalists have not found it possible to make many extensive observations of this interesting bird during the breeding season, in June, because it nests in a region subject to violent weather changes during the early summer, making a camping outfit imperative to provide against violent storms.

\section{PRAIRIE CHICKEN}

The Prairie Chicken, or Prairie Hen, was formerly one of the most common birds on the plains and prairies of the middle and western United States and Canada. In Minnesota and Manitoba this famous bird is found in the same districts as its lighter-plumaged relative, the sharp-tailed 


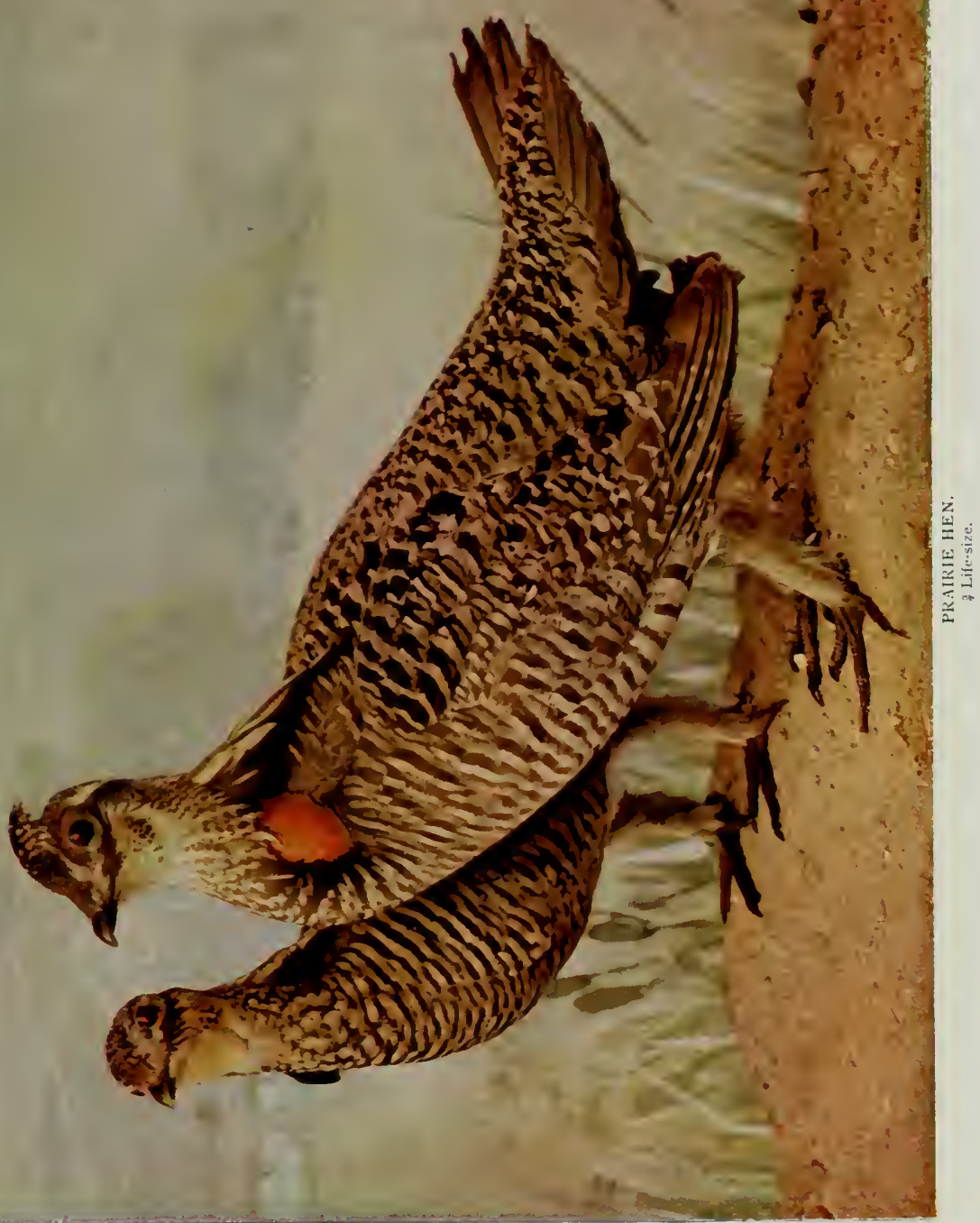



grouse. Certain portions of Oklahoma, Kansas, and Texas are the haunts of the rare and smaller form, known as the lesser prairie chicken.

The prairie chicken, or pinnated grouse, like the turkeys, are polygamous. In August the young and old congregate in droves, numbering from a dozen to upwards of a hundred. Over the grain and stubble fields and into plowed ground these flocks forage from early fall until the first spring thaws. In March and early April they begin to disband, and the males may then be heard "booming" at sunrise from some elevated spot exposed on all sides. The cocks have a small patch of loose skin on either side of the neck, which they are capable of inflating with air until these bare spots swell to the size of a large crabapple, resembling little oranges. While the males are filling and emptying these pouches the head is lowered and the wings partially spread and drooping. Several cocks assume this posture simultaneously, each facing the others and booming alternately. At this juncture it is not an unfamiliar sight to see a hen fly directly in their midst, when a battle royal ensues. Perhaps the madam has just left a setting of nine to eighteen eggs, but she soon leaves the rivals to their comical antics.

The nest is usually prepared in a sheltered spot, under a clump of dead weeds or a bunch of weather-beaten grass, or at the base of a small bush or shrub. The parent scratches a slight hollow in the earth, lining it with dead vegetation and a few feathers from her own breast. The first egg is laid sometimes as early as April 20th, but usually during the forepart of May. The period of incubation is three 
weeks, and the young follow the mother as soon as hatched.

The prairie chicken has many natural enemies. Snakes, weasels, minks, coyotes, rats, and crows are among the many which tend to decrease the broods by destroying the eggs and devouring the chicks. What could be a more tempting morsel for the horned owl or a prairie falcon? Wet, cold springs retard the nesting, and result frequently in flooding the nests. The prairie chicken usually deserts a disturbed nest, and now too few good nesting sites remain. Fortunately, many states have protected these birds for some years by not allowing any shooting. As a result in many sections this magnificent bird, so beneficial to the farmer, is occurring in something like its former abundance. They are hardy birds, residing the year round in the same locality unless driven to other sections by persecution.

'Their food is principally grain, berries, grasshoppers, beetles, and willow buds. Their value to the farmer is almost as important as that of the bob-white and meadow lark, all of which thrive in cultivated sections, where the agriculturist must realize that the day is not far distant when he must choose between the grasshopper and other pests and these resident game birds, which thrive if they are afforded protection from the gunner.

\section{THE LESSER PRAIRIE HEN*}

Extending over the great plains from western and probably southern Texas northward through Oklahoma to Kansas is said to be the habitation of the Lesser Prairie Hen, though it is not fully known. It inhabits the fertile prairies, 


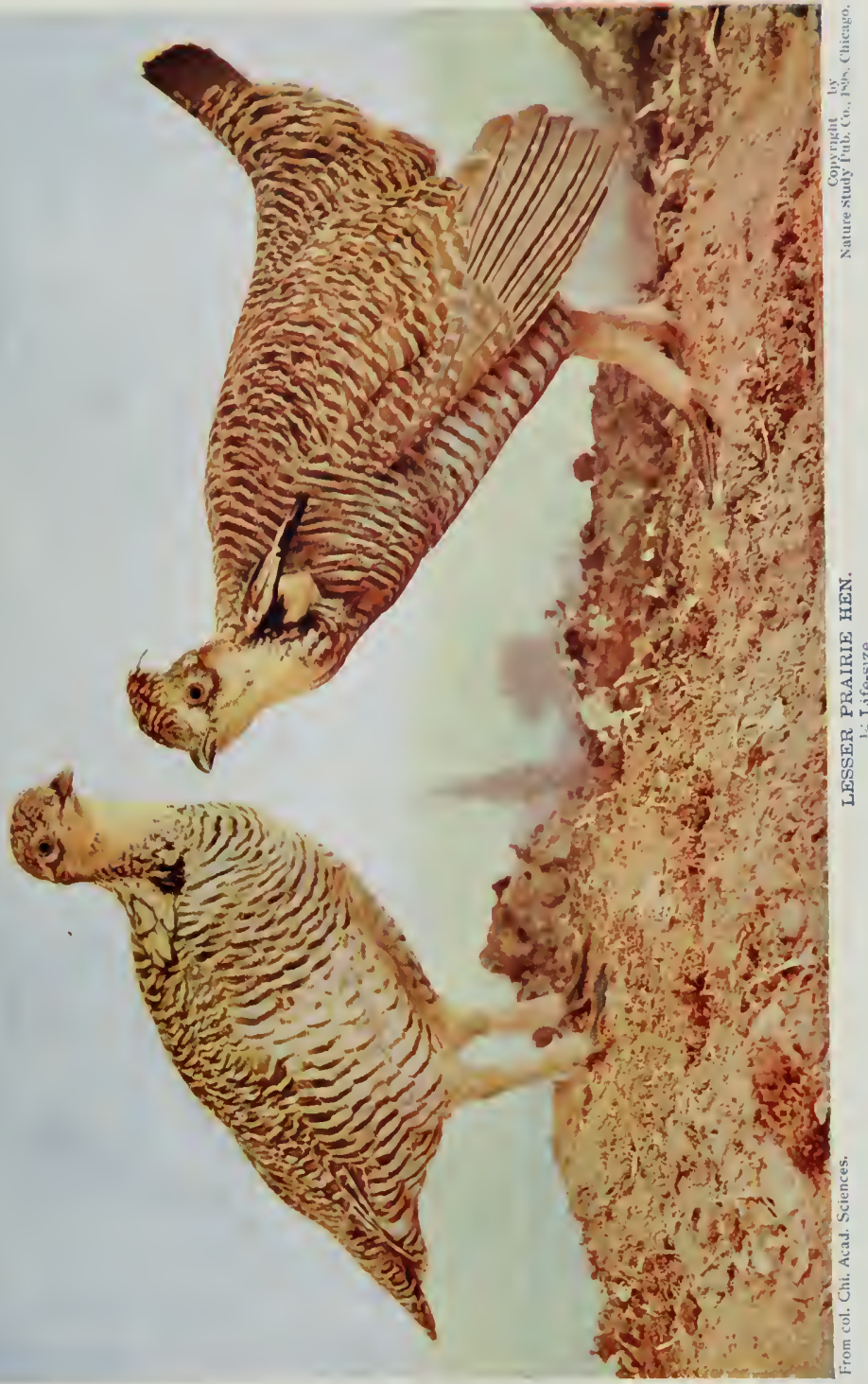



seldom frequenting the timbered lands, except during sleety storms or when the ground is covered with snow. Its flesh is dark and it is not very highly esteemed as a table bird.

The labits of these birds are similar to those of the prairie hen. During the early breeding season they feed upon grasshoppers, crickets, and other forms of insect life, but afterwards upon cultivated grains gleaned from the stubble in autumn and the cornfields in winter. They are also fond of tender buds, berries, and fruits. When flushed these birds rise from the ground with a less whirring sound than the ruffed grouse or bob-white, and their flight is not as swift but more protracted and with less apparent effort, flapping and sailing along, often to the distanee of a mile or more. In the fall the birds come together and remain in flocks until the mating season of spring.

The nest of the prairie hen is placed on the ground, in the thick prairie grass, and at the foot of bushes when the earth is barren; a hollow is scratched in the soil and sparingly lined with grasses and a few feathers. There are from eight to twelve eggs, tawny brown, sometimes with an olive hue and occasionally sprinkled with brown.

During the years 1869 and 1870 , while the writer was living in southwestern Kansas, which was then the far West, prairie chickens, as they were called there, were so numerous that they were rarely used for food by the inhabitants, and, as there was then no readily accessible market, the birds were slaughtered for wanton sport. 'They have become wellnigh exterminated in many localities where they were formerly very abundant, owing to the inmense numbers that hunters have shot to be sold in the eastern markets. 


\section{PRAIRIE SHARP-TAILED GROUSE}

The Sharp-tailed Grouse, in this form, is found chiefly in the Dakotas, Minnesota, and western Wisconsin. Occasionally they have been recorded in northern Illinois. It is partially migratory, living in prairies in summer and wooded regions in winter.

The true form of the sharp-tailed grouse is a more northerly species, inlabiting the west and central portions of Manitoba and Alberta. In the northwestern section of the United States, from Montana to the Pacific, including Washington and Oregon, the Columbian sharp-tailed grouse, another species, occurs. The sharp-tailed grouse may be met with in the same sections occupied by our common prairie chicken, but may be readily distinguished from it by the feathered legs and toes. The Columbian sharptailed is fond of wild fruit, so that during the fall they move from the prairie lands into the cranberry marshes to feed.

Prairie sharp-tailed grouse are considerably lighter in color than the prairie chicken, and the under parts are without the barred effect. In winter they hide in the deep snow and tunnel beneath the crust to feed on the sprouts of willows, larches, and aspens. Like the ruffed grouse, it frequently roosts in trees, but during the spring and summer months it remains on the ground.

From seven to twelve eggs are laid in May or early in June. Some sets bear a close resemblance to those of the prairie chicken and are dark olive-green. Others are gray- 


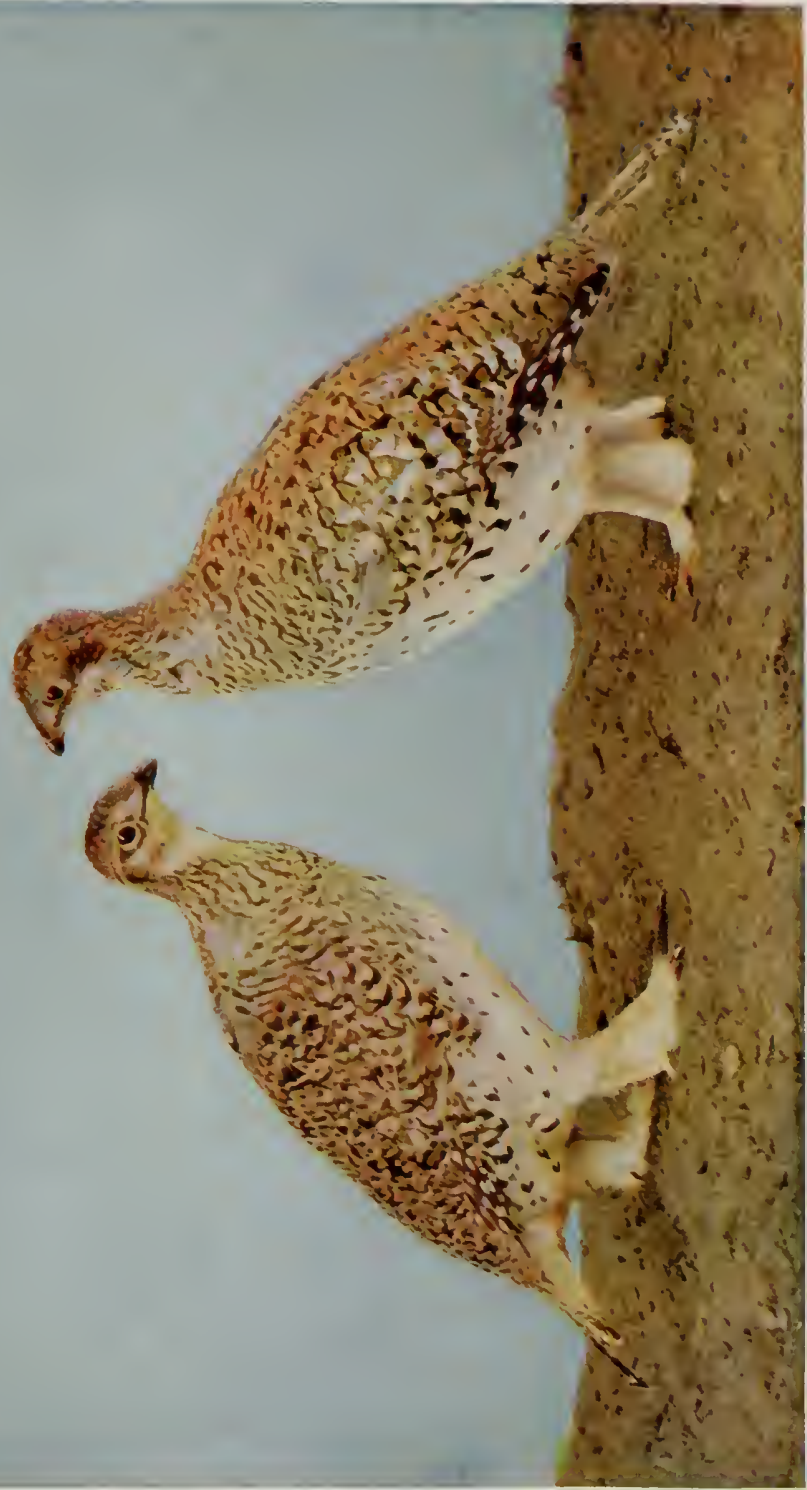



ish-drab sparingly covered with markings of pale brown. I found this bird breeding in the rolling prairies of western Minnesota during the first half of June.

\section{WILD TURKEY}

This great game bird is nearing extinction in many sections of the United States. Fifty years ago it was of common occurrence from the Atlantic to Kansas and Missouri, while today few states can claim this noble bird as a resident. A sub-species, the Florida wild turkey, haunts the almost inaccessible portions of Florida, where shrubbery and wild fruits prevail. In the Southwest other varieties still range in the mountainous regions of Missouri, Arkansas, Oklahoma, Texas, New Mexico, and Arizona.

In the Aransas Pass region of southwestern Texas I encountered several small flocks of the Mexican wild turkey in February and March, when the gobblers were noisy and aggressive. The Mexicans sometimes use dogs in hunting this gallinaceous fowl; when pursued down hill it does not seem to occur to these birds that escape is possible by flight only and as a result they are caught. I have never known a dog to capture one when the turkey was running up a hill, though turkeys seldom take refuge from a dog by flight.

Large pecan trees in the mountains, along little streams, are favorite roosting-places for these wild turkeys, which frequent the same tree nightly. Before sunrise the males of these polygamous birds may be seen strutting through the fields with drooping.wings, gobbling incessantly and chal- 
lenging every other gobbler. I was fortunate in discorering a nest under a fallen tree, on a little knoll between two gullies. The bird used a large quantity of dead leaves and feathers in constructing the nest, so that it was suggestive of a wild duck's nest. It contained thirteen eggs when found. In shape and markings they resemble those of the domestic turkey, but are slightly paler and smaller. The nest is generally abandoned if the eggs are touched.

\section{PASSENGER PIGEON}

The former range of the Passenger Pigeon, or Wild Pigeon, was eastern North America northward to Hudson Bay.

"No more marvelous tales have been handed down to us from a remote past than those which our own fathers tell concerning the former abundance of the wild pigeon dúring its migrations and in its breeding haunts. During their passage the sun was darkened, the beating of their wings was like thunder, and their steady oncoming like the continuous roar of Niagara. Where they roosted great branches, and even trees two feet in diameter, were broken down beneath their weight, and where they bred a hundred square miles of timber was weighted down with their nests. When they lighted on the ground in vast swarms to feed, the rear birds flew over the flock to alight in front, looking like a rolling surf wave of blue.

" Until the middle of the last century the species enjoyed a general distribution throughout eastern North America, and was found scatteringly to the Pacific Coast. The birds 
were, however, rather irregular in thcir habits, and the center of abundance within historic times was in the North Central States. They were best known from Kentucky, through the accounts of Wilson and Audubon, and in Michigan, where the birds had their last known stronghold, and where the last considerable flight was observed, in 1888. In Kentucky they bred and occasionally wintered in such numbers that Wilson once computed a single flight at upwards of two billions. Since the pigeons appeared absolutely countless, their destruction was carried forward upon a colossal scale. Men gathered them with ncts and knocked them down with poles, or felled trees to secure the fat squabs. At Pentwater, Michigan, people lined the cliffs and beat them down with sticks as they passed the crest of the ridge, until the ground was heaped with countless thousands. Powder and shot were deemed unnecessary, although fifty-nine pigeons are reported as killed by one discharge of a shotgun.

"In 1878 Prof. H. B. Roney wrote in the Chicago Ficld (Vol. X, pp. 345-347) :

"“'The nesting area situated near Petoskey included not less than 150,000 acres within its limits. The number of the dead birds sent by rail was estimated at 12,500 daily, or $1,500,000$ for the summer, besides 80,352 live birds; and an equal number was sent by water. We have,' says the writer, 'adding the thousands of dead and wounded ones not secured, and the myriads of squabs left dead in the nest, at the lowest possible estimate, a grand total of $1,000,000$,000 pigeons sacrificed to mammon during the nesting of 1878.' 
"It is evident that such wholesale slaughter could not go on forever. 'The extraordinary flights suddenly ceased during the '80s. Since that time, "What has become of the passenger pigeon?' has been the puzzling question. It is known that the birds still breed by single pairs, to some extent at least; but doubtless the passenger pigeons are gone - gone irretrievably, after the manner of the bisonlost in the maw of human greed.

"One or two white eggs in a rude platform of sticks was laid on every available branch." (Adapted from Dawson's Birds of Ohio.)

\section{MOURNING DOVE}

The Mourning Dove ranges throughout the United States and southern Canada, breeding from Cuba north to Ontario and Quebec.

Since the extinction of the passenger pigeon, the mourning or turtle dove is the only representative of the family we have in eastern North America north of Florida and Louisiana. The bird's rapid and irregular flight is accompanied by a whistling of the wings. Disturbed while nesting, the birds alternately flutter and hop until they have misled the trespasser. Mourning doves are gregarious when migrating, and again flock soon after the young leave the nest. When gregarious they visit cornfields, consequently their flesh is very palatable, and farmers kill then in great numbers in open season as game and because of their destruction of grain. Fond of salt, they are found where stock is salted. 


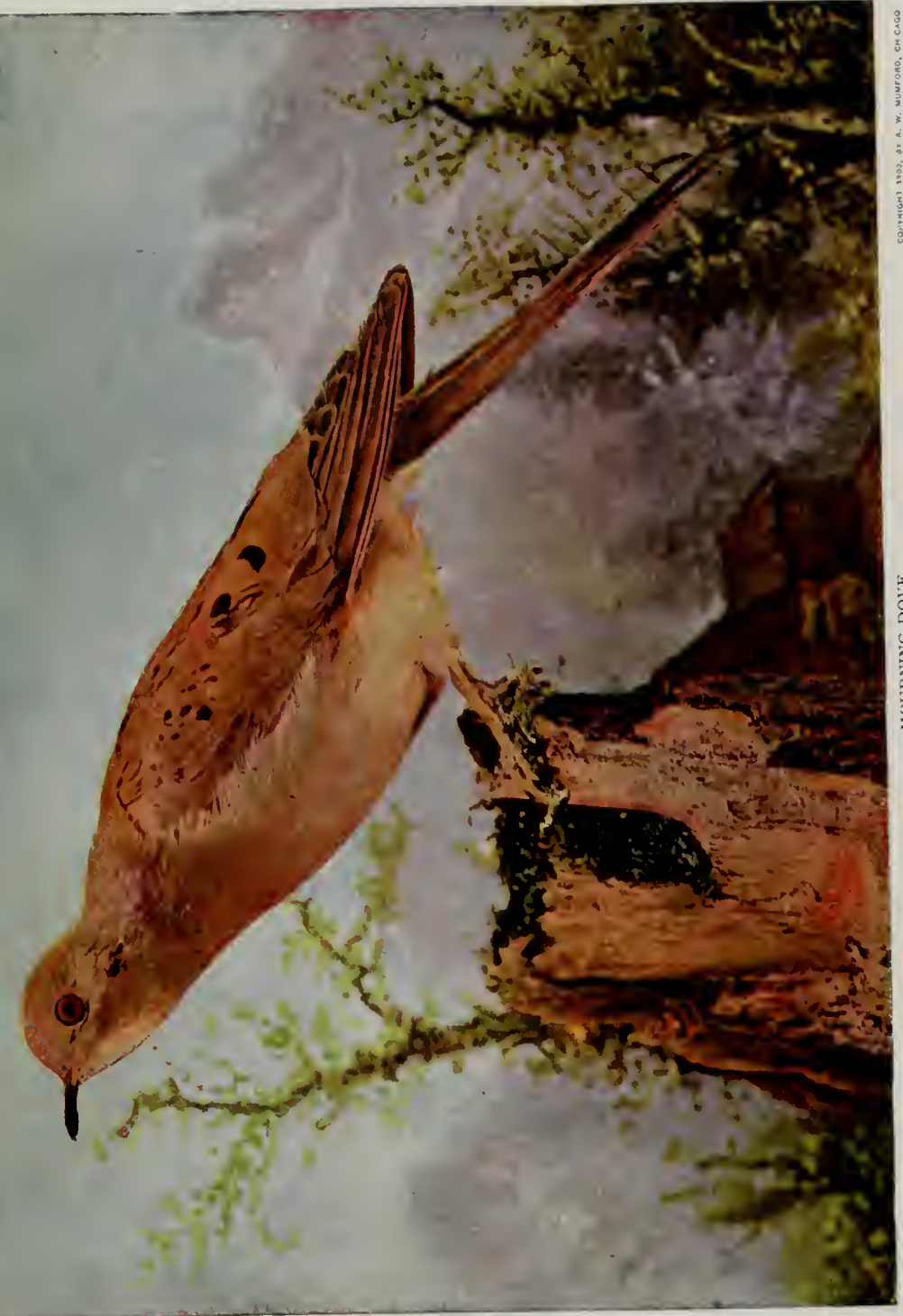

西 



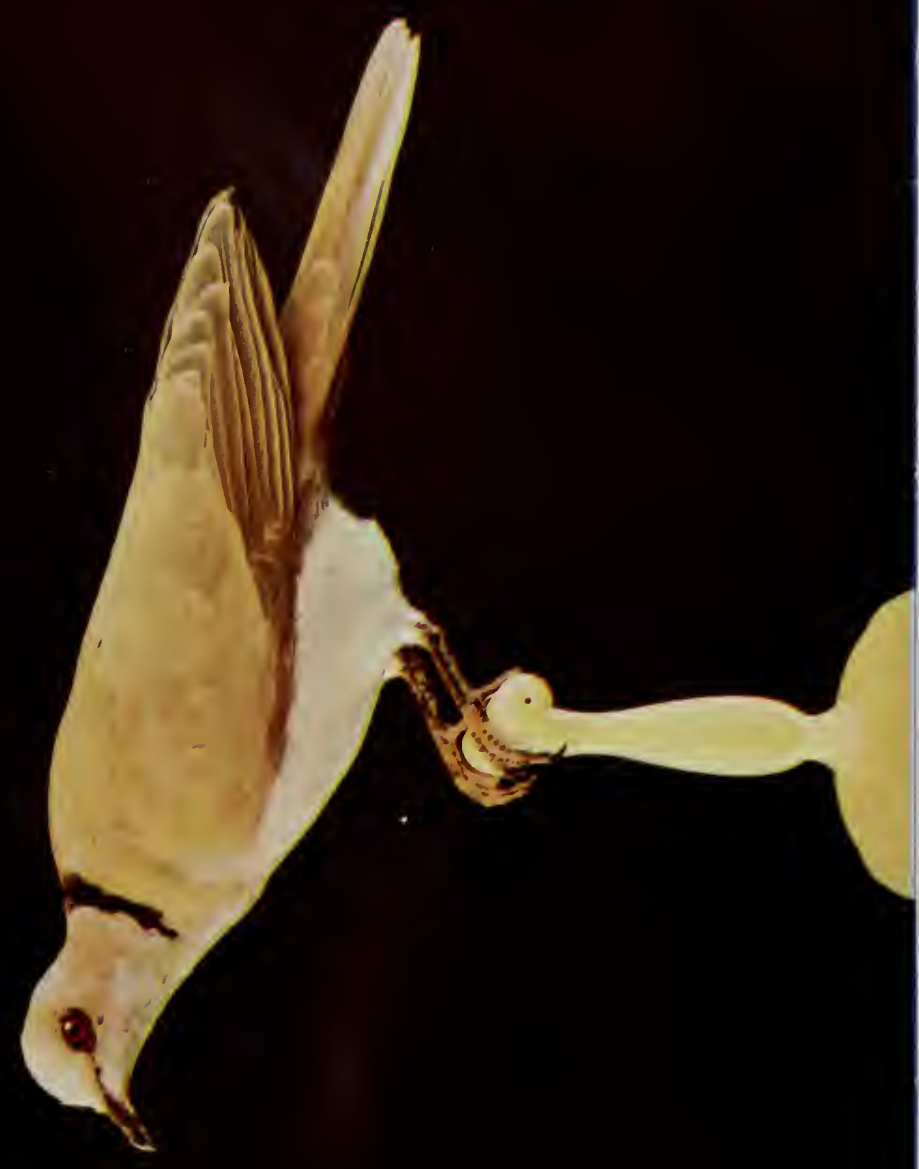



The love song has a pathetic tone which gives the name "mourning." Orchards, groves, and roadsides grown up with shrubbery are favorite ncsting sitcs. The young are fed after the manner of the albatross, petrels, and hummingbirds, as the predigested matter is introduced into the crop of the young by regurgitation.

Two white eggs are deposited in a loosely constructed nest of sticks, near the ground in the East, sometimes on the ground in the West.

\section{RING-NECKED DOVE*}

The popular names for this favorite bird are turtle dore, common dove, and Carolina dove. It is an inhabitant of all of temperate North America to a little north of the United States boundary, south through MIexico and Central America to the Isthmus of Panama, Cuba, Jamaica, and some other West Indian islands. The species have even been known to winter as far north as Canada, Mr. John J. Morley, of Windsor, Ontario, informing Prof. Baird that he had seen considerable numbers near that place on the 6th of December, 1878, and that he had on other occasions seen it in various places, from three to twelve at a time. It is a common summer resident in Illinois. The majority arrive the last of March or first of April, and depart by the middle of October. In many places it becomes partly domesticated, breeding in the trees in the yard and showing but little fear when approached. 





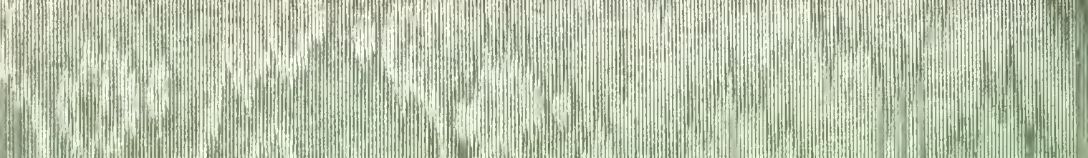

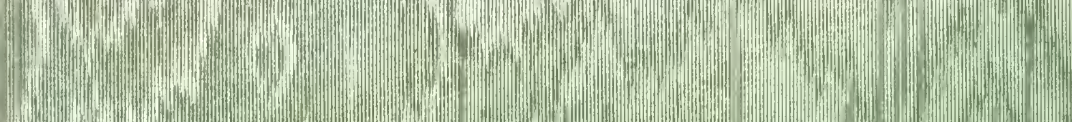

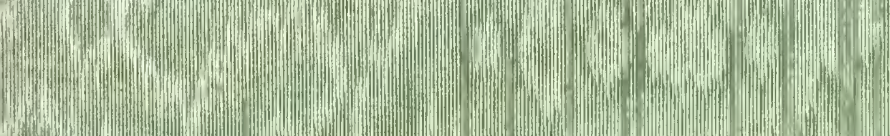

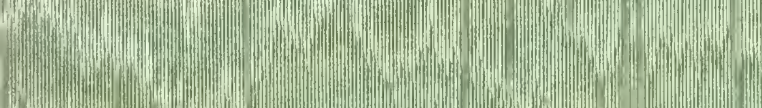

(1)

10.

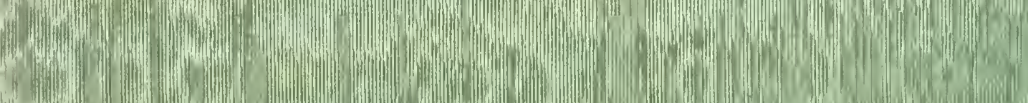

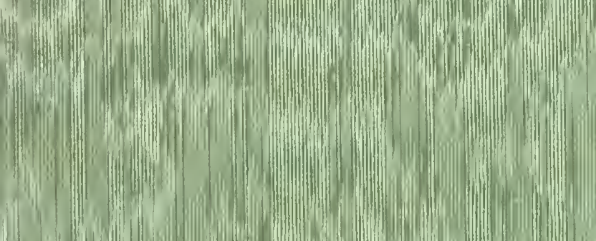

(3)

(1)

(I)

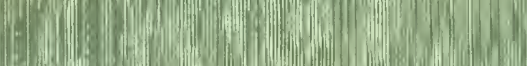

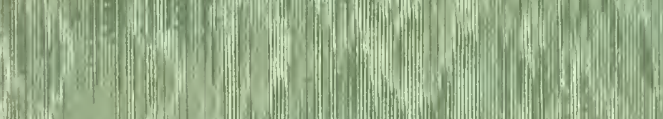

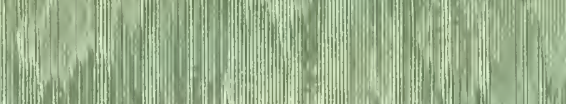

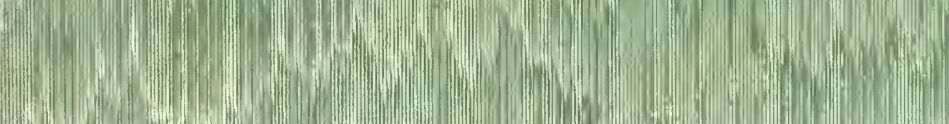

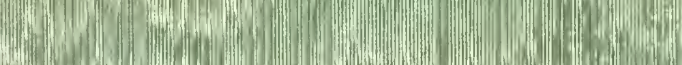

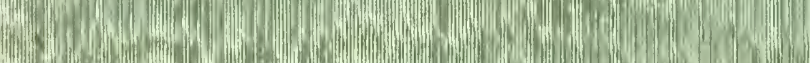

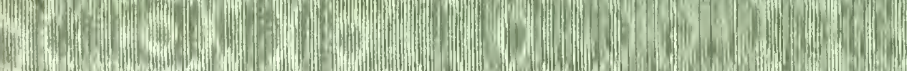

(1)

18 -

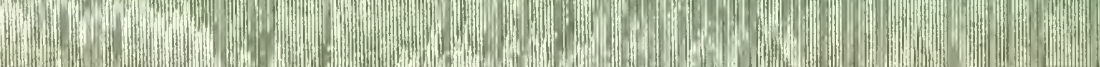




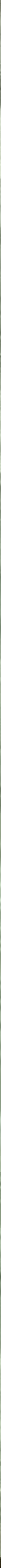


